
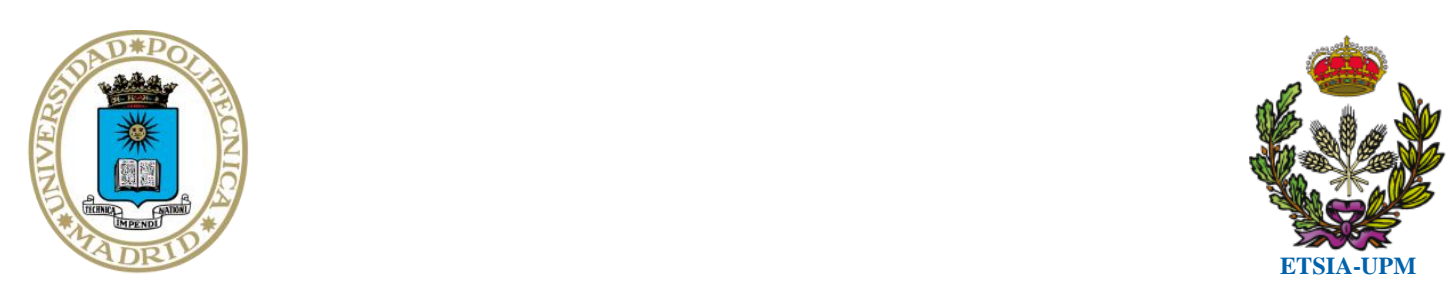

UNIVERSIDAD POLITÉCNICA DE MADRID

ESCUELA TÉCNICA SUPERIOR DE INGENIERÍA AGRONÓMICA, ALIMENTARIA Y DE BIOSISTEMAS

\title{
Effect of arginine and glutamine supplementation, dietary soluble fibre level and n-6/n-3 fatty acid ratio on rabbit performance and intestinal health
}

\section{TESIS DOCTORAL}

María Rebeca Delgado Morcillo

Ingeniero Agrónomo 

UNIVERSIDAD POLITÉCNICA DE MADRID

ESCUELA TÉCNICA SUPERIOR DE INGENIERÍA AGRONÓMICA, ALIMENTARIA Y DE BIOSISTEMAS

\section{Effect of arginine and glutamine supplementation, dietary soluble fibre level and n-6/n-3 fatty acid ratio on rabbit performance and intestinal health}

María Rebeca Delgado Morcillo

Ingeniero Agrónomo

DIRECTORES DE TESIS 

Index 



\section{INDEX OF CONTENTS}

\section{ABBREVIATION LIST}

RESUMEN

SUMMARY

\section{CHAPTER 1: LITERATURE REVIEW AND OBJECTIVES}

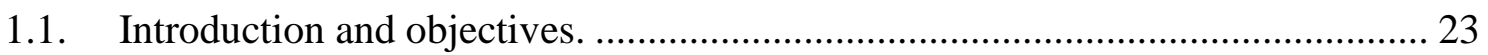

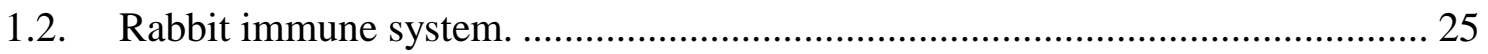

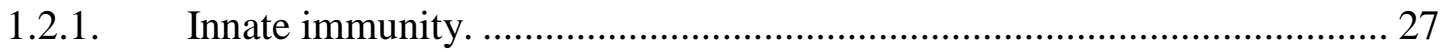

1.2.2. Adaptive immunity: the gut associated lymphoid tissue......................... 28

1.2.3. Rabbit immune response in health and disease ...................................... 31

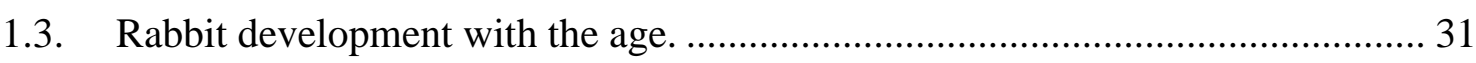

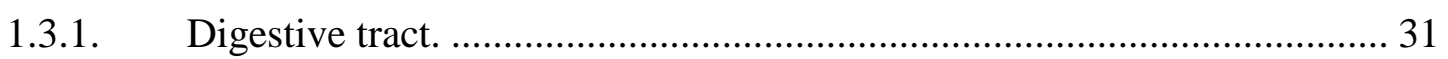

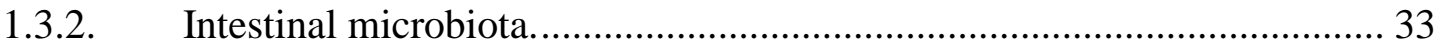

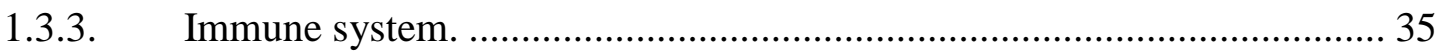

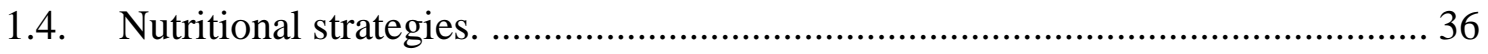

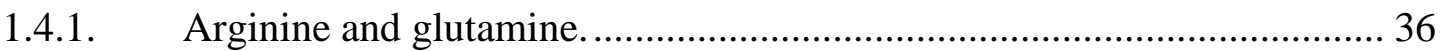

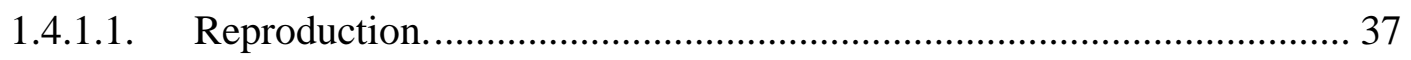

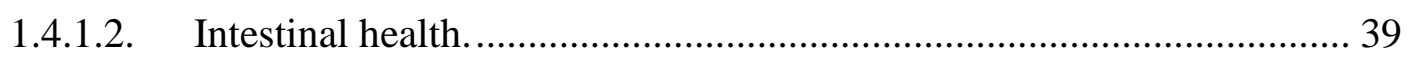

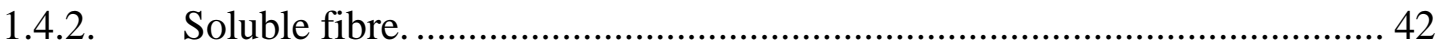

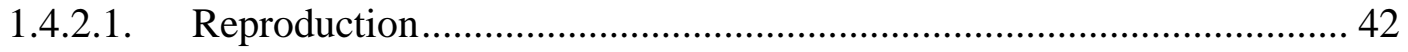

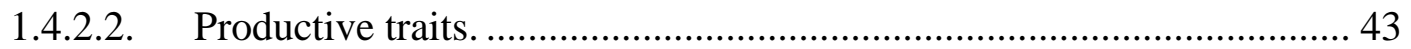

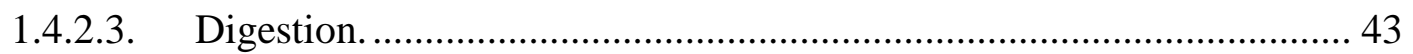

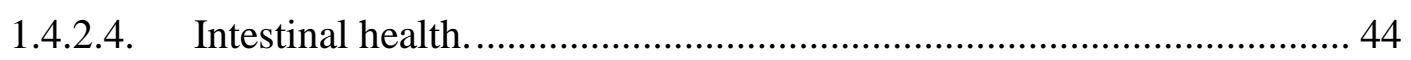

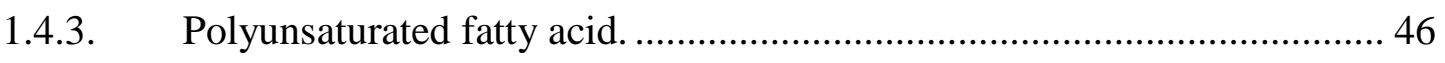

1.4.3.1. Reproduction and milk composition................................................ 47

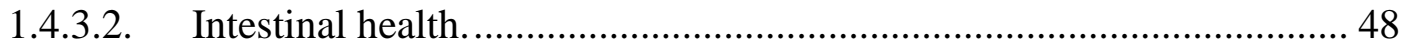


CHAPTER 2: EVOLUTION OF ILEAL AND CAECAL MICROBIOTA, INTESTINAL, IMMUNE RESPONSE AND DIGESTIVE TRACT IN RABBIT WEANED AT 26 DAYS OF AGE.

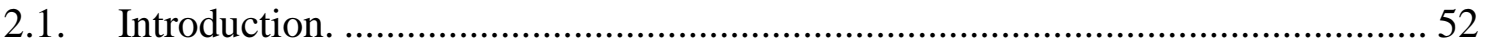

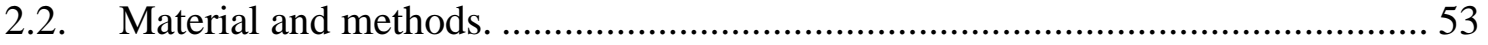

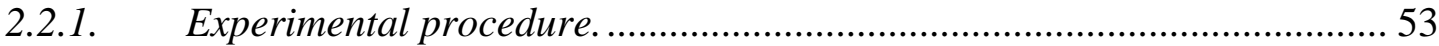

2.2.2. Determination of mucosa morphology................................................ 53

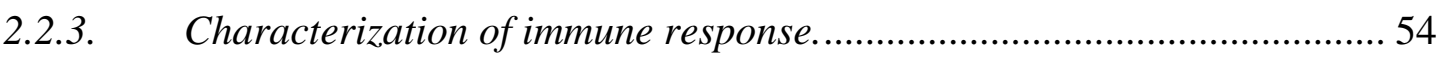

2.2.4. Characterization of intestinal microbiota ............................................... 55

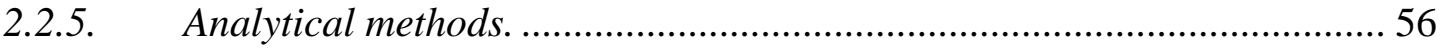

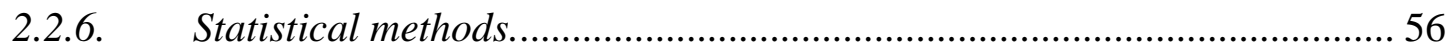

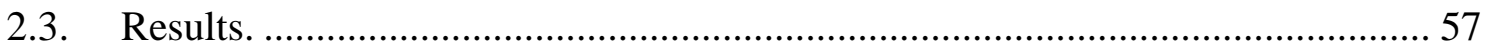

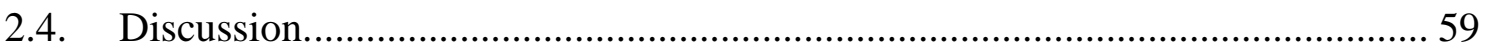

\section{CHAPTER 3: ARGININE AND GLUTAMINE DIETARY SUPPLEMENTATION}

3.1. Effect of dietary supplementation with arginine and glutamine on the performance of rabbit does and their litters during the first three lactations..................................... 74

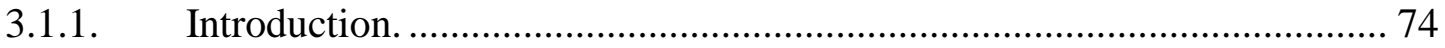

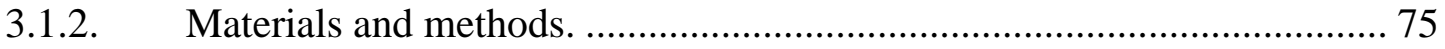

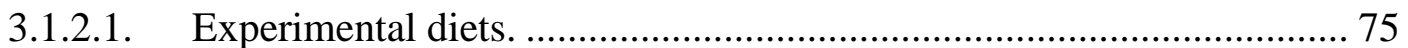

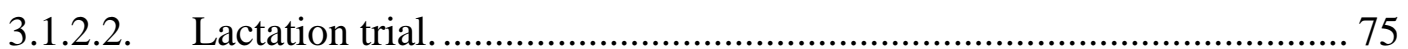

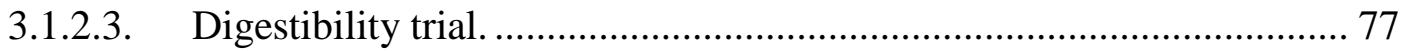

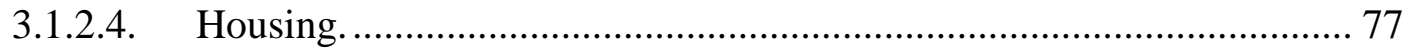

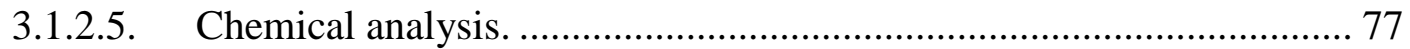

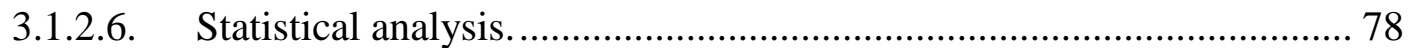

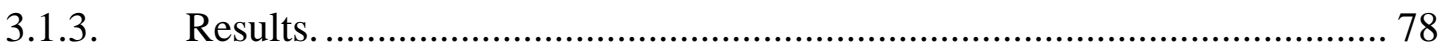

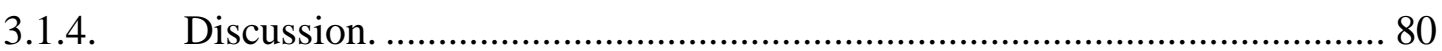

3.2. Effect of pre- and post-weaning dietary supplementation with arginine and

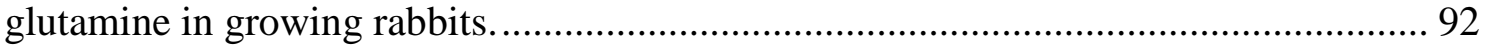

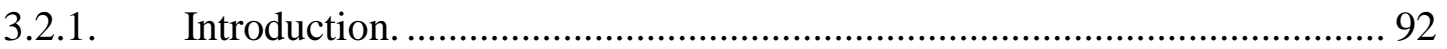

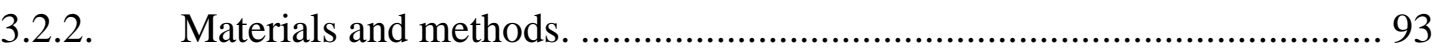

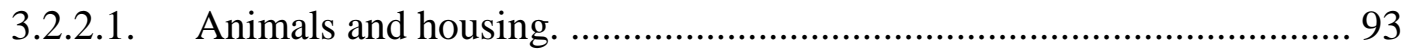

3.2.2.2. Growth performance and mortality trial. ........................................... 93

3.2.2.3. Apparent ileal digestibility........................................................... 94

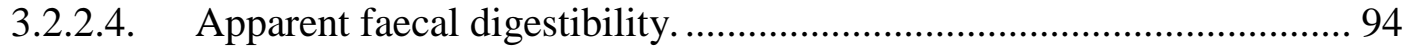


3.2.2.5. Carcass chemical composition trial and calculations of energy and

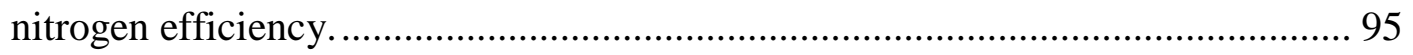

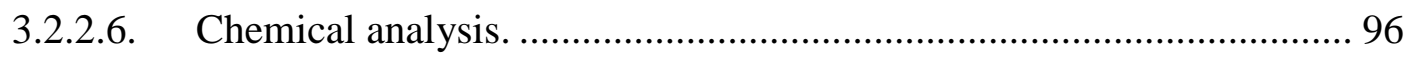

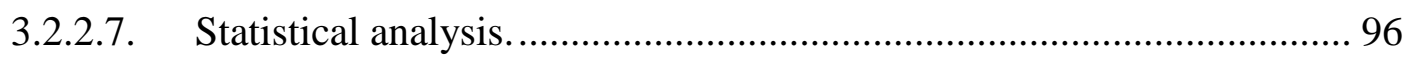

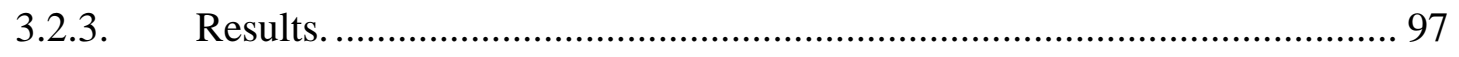

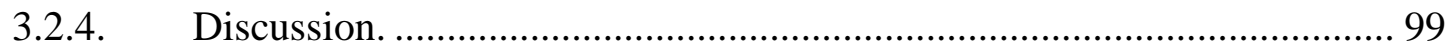

3.3. Effect of pre- and post-weaning dietary supplementation with arginine and glutamine on rabbit performance and intestinal health. .......................................... 110

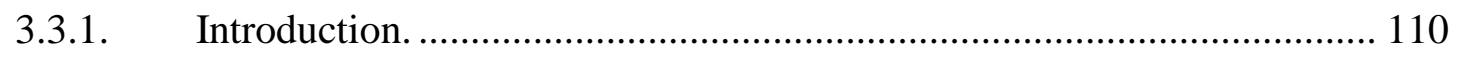

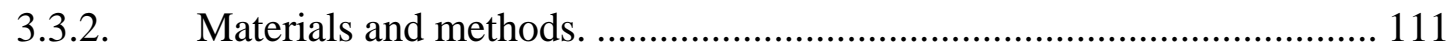

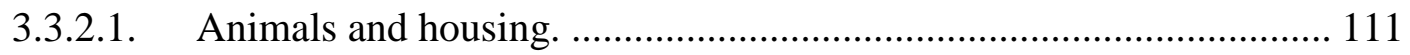

3.3.2.2. Bacterial translocation to mesenteric lymphoid nodes...................... 111

3.3.2.3. Gut histology and enzymatic activity. ......................................... 112

3.3.2.4. Phenotypical and functional analysis of intraepithelial lymphocytes from

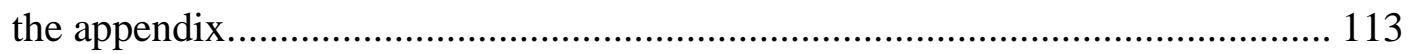

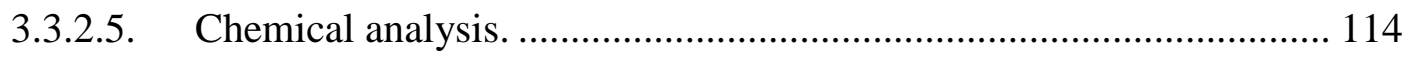

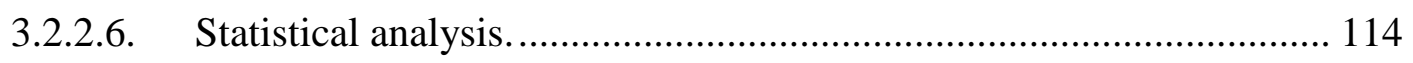

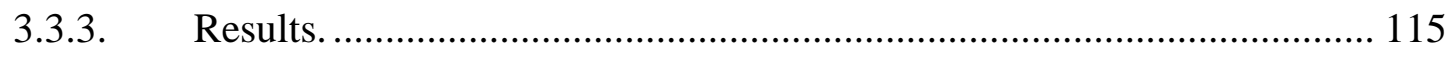

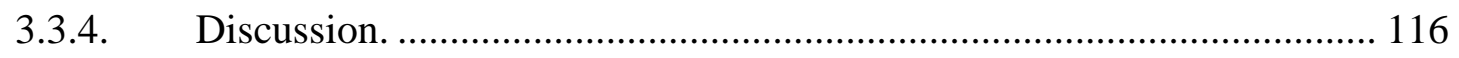

\section{CHAPTER 4: SOLUBLE FIBRE LEVEL AND n6/n3 FATTY ACID RATIO}

4.1. Effect of dietary soluble fibre level and n-6/n-3 fatty acid ratio on the performance of rabbit does and their litters during the first four lactations. .................................. 132

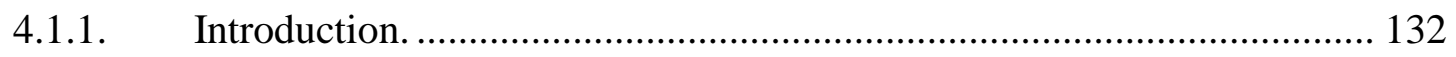

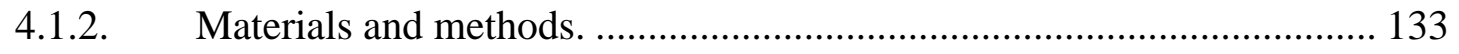

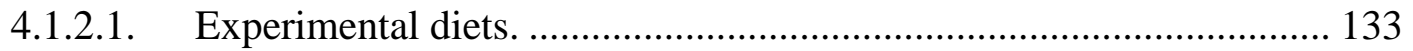

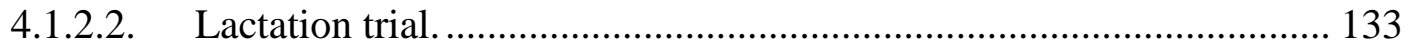

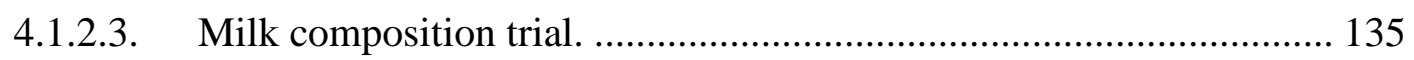

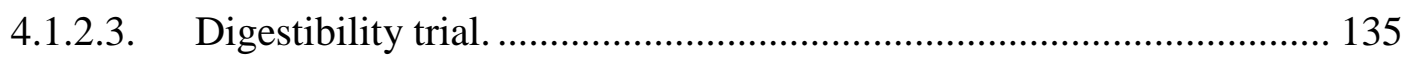

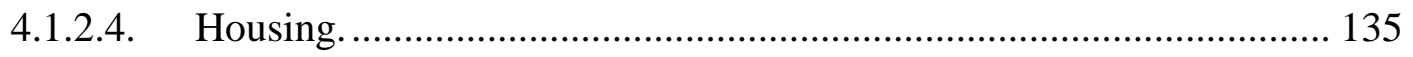

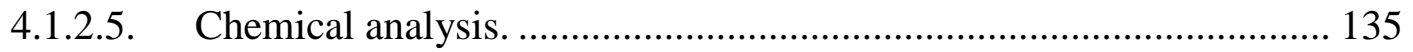

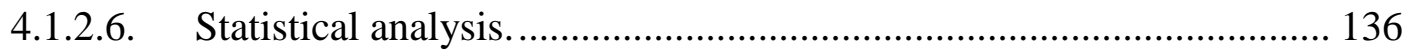

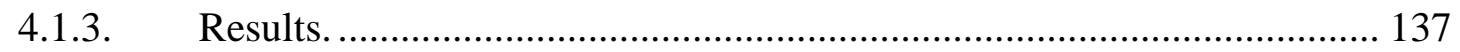

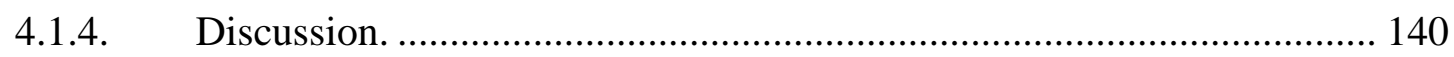


4.2. Effect of dietary soluble fibre level and n-6/n-3 fatty acid ratio on growth performance and nutrient and energy efficiency in growing rabbits........................... 156

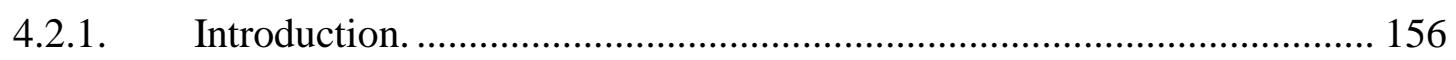

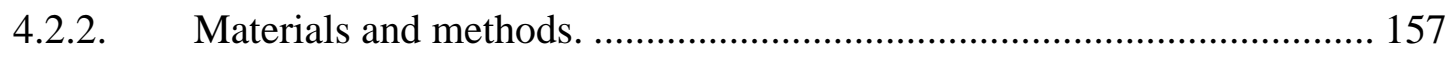

4.2.2.1. Animals and housing. .................................................................... 157

4.2.2.2. Growth performance and body chemical composition trial............... 157

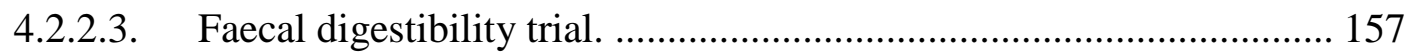

4.2.2.4. Calculations of energy and nitrogen efficiency. .............................. 158

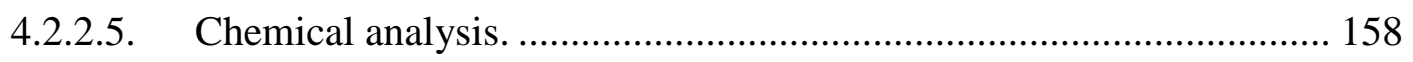

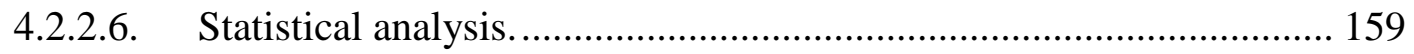

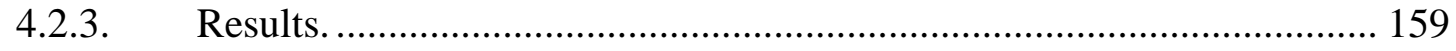

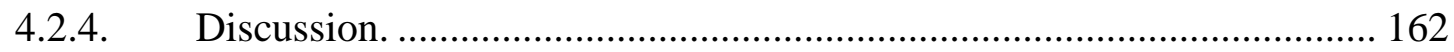

4.3. Effect of dietary soluble fibre level and n-6/n-3 fatty acid ratio on digestion and

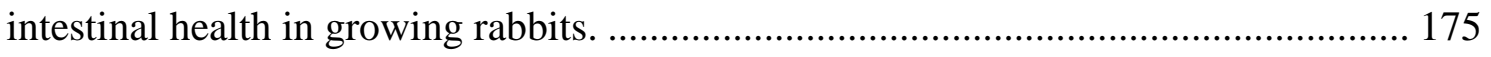

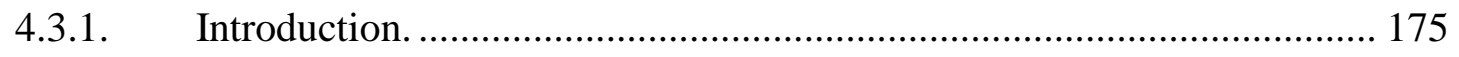

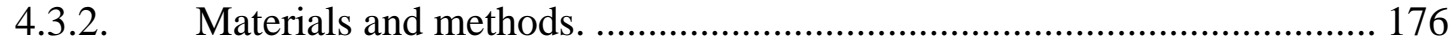

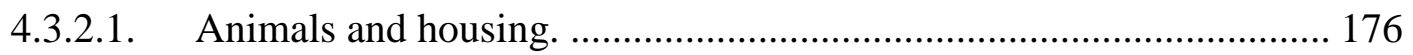

4.3.2.3. Trial 2. Mortality trial in collective cages with the experimental diets fed

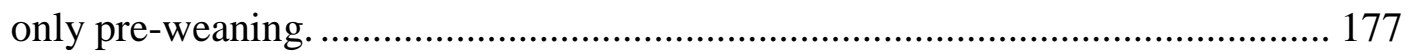

4.3.2.4. Trial 3: Faecal digestibility and soft faeces excretion. ...................... 177

4.3.2.5. Trial 4: Ileal digestibility, digestive traits, sucrose activity and immune function. 178

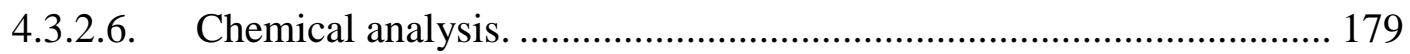

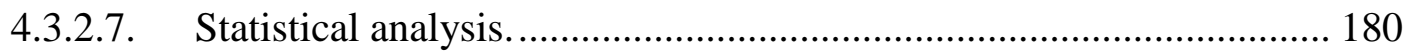

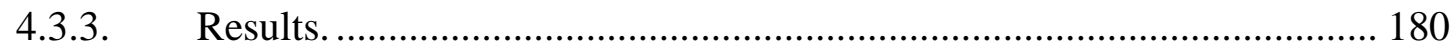

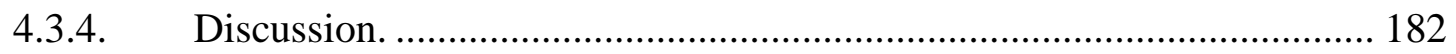

CHAPTER 5: GENERAL DISCUSSION

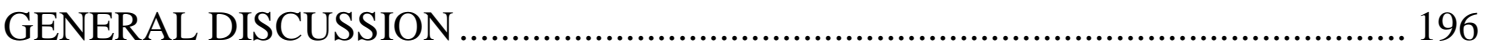

CHAPTER 6: GENERAL CONCLUSION

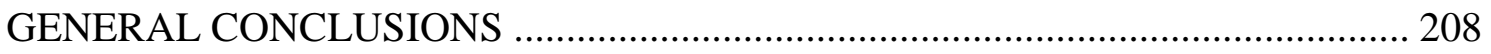

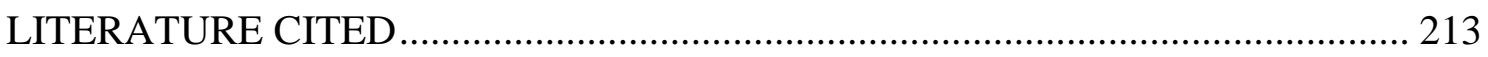


Abbreviation List 



\section{ABBREVIATION LIST / LISTA DE ABREVIATURAS}

Abbreviation /

Abreviatura

ADF

ADFI

ADG

ADL

AI

ALA

ARA

Arg

Arg+Gln

BIA

BW

C

$\mathrm{CD4}^{+}$

$\mathrm{CD45}^{+}$

$\mathrm{CD5}^{+}$

$\mathrm{CD8}^{+}$

cDNA

CFU

CP

$\mathrm{Ct}$

D

DE

$\mathrm{DE}_{\mathrm{i}}$

DHA

DM

DMSO

$\mathrm{DN}_{\mathrm{i}}$

DP/DE ratio

eCG

EPA

ERE

ER carcass

ER in vivo

GADPH

GALT

GE

$\mathbf{G E}_{\mathbf{i}}$

G:F

Gln
English

Acid detergent fibre

Average daily feed intake

Average daily gain

Acid detergent lignin

Artificial insemination

$\alpha$-Linolenic acid

Arachidonic acid

Arginine diet

Arginine + glutamine diet

Bioelectrical impedance analysis

Body weight

Control diet

Helper lymphocytes

Lymphocytes

B or T lymphocytes

Cytotoxic lymphocytes

Complementary DNA

Forming colonies unit

Crude protein

Threshold

Day

Digestible energy

Digestible energy intake

Docosahexaenoic acid

Dry matter

Dimethyl sulfoxide

Digestible nitrogen intake

Digestible protein/digestible energy

Equine chorionic gonadotropin

Eicosapentanoic acid

Epizootic rabbit enteropathy

Energy retained in carcass

Energy retained in vivo

Glyceraldehyde- 3 phosphate

Gut associated lymphoid tissue

Gross energy

Gross energy intake

Gain feed conversion ratio

Glutamine diet
Castellano

Fibra ácido detergente

Consumo medio diario

Ganancia media diaria

Lignina ácido detergente

Inseminación artificial

Ácido $\alpha$ linolénico

Ácido araquidónico

Pienso arginina

Pienso arginina + glutamina

Análisis de impedancia bioeléctrica

Peso vivo

Pienso control

Linfocitos cooperadores

Linfocitos

Linfocitos B o T

Linfocitos citotóxicos

ADN complementario

Unidades formadoras de colonias

Proteína bruta

Valor del ciclo umbral

Día

Energía digestible

Energía digestible ingerida

Ácido docosahexahenoico

Materia seca

Dimetil sulfóxido

Nitrógeno digestible ingerido

Proteína digestible/energía digestible

Gonadotropina coriónica equina

Ácido eicosapentanoico

Enteropatía epizoótica del conejo

Energía retenida en la canal

Energía retenida in vivo

Gliceraldehido 3-fosfato

Tejido linfático asociado al intestino

Energía bruta

Energía bruta ingerida

Eficacia alimenticia

Pienso glutamina 


\section{GnRH}

HBSS

HEPES

HFS

Hn-6/n-3

HPRT

IELS

IFN- $\gamma$

IgA

IL

iNOS

LA

LSF

Ln-6/n-3

MHC

MHC I

MCH II

MLN

mRNA

MUC-1

MUC-13

MUFA

$\mathbf{N}$

NDF

NDSF

NF-kB

$\mathbf{N}_{\mathbf{i}}$

NO

NR carcass

$\mathrm{NR}$ in vivo

NS

OFA

OM

OTUs

PBS
Gonadotropin-releasing hormone agonist

Hank's balance salt solution

4-(2-hydroxyethyl)-1-

piperazineethanesulfonic acid

High soluble fibre

High n-6/n-3 ratio

Hypoxanthine

phosphoribosyltransferase

Intraepithelial lymphocytes

Interferon gamma

Immunoglobulin A

Interleukin

Inducible nitric oxide synthase

Linoleic acid

Low soluble fibre

Low n-6/n-3 fatty acid ratio

Immune histocompatibility

complex

Immune histocompatibility

complex I

Immune histocompatibility complex II

Mesenteric lymph node

Messenger RNA

Mucin linked membrane 1

Mucin linked membrane 13

Monounsaturated fatty acids

Number of replicates

Neutral detergent fibre

Neutral-detergent soluble fibre

Nuclear factor kappa-light-chain-

enhancer of activated $B$ cells

Nitrogen intake

Nitric oxide

Nitrogen retained in carcass

Nitrogen retained in vivo

Non significative

Odd fatty acids

Organic matter

Operational taxonomic units

Phosphate buffered saline
Hormona liberadora de

gonadotropina

Ácido 4-(2-hidroxietil)-1-

piperazineetanesulfonico

Alta fibra soluble

Alto ratio n-6/n-3

Hipoxantina

phosphorribosiltransferasa

Linfocitos intraepiteliales

Interferón gamma

Inmunoglobulina A

Interleucina

Óxido nítrico sintasa inducible

Ácido linoleico

Alta fibra soluble

Bajo ratio ácidos grasos n-6/n-3

Complejo inmune de

histocompatibilidad

Complejo inmune de

histocompatibilidad I

Complejo inmune de

histocompatibilidad II

Nódulo linfático mesentérico

ARN mensajero

Mucina ligada a la membrana 1

Mucina ligada a la membrana 13

Ácidos grasos monoinsaturados

Número de réplicas

Fibra neutro detergente

Fibra soluble neutro detergente

Factor nuclear potenciador de las

cadenas ligeras kappa de las células B

activadas

Nitrógeno ingerido

Óxido nítrico

Nitrógeno retenido en la canal

Nitrógeno retenido in vivo

No significativo

Ácidos grasos de cadena impar

Materia orgánica

Unidades taxonómicas operacionales

Tampón fosfato salino 


\begin{tabular}{|c|c|c|}
\hline PCR & polymerase chain reaction & Reacción en cadena de la polimerasa \\
\hline PPAR- $\gamma$ & $\begin{array}{l}\text { Peroxisome proliferator-activated } \\
\text { receptor }\end{array}$ & $\begin{array}{l}\text { Proliferador de peroxisoma activado } \\
\text { de los receptores }\end{array}$ \\
\hline PUFAs & Polyunsaturated fatty acids & Ácidos grasos poliinsaturados \\
\hline RPMI & $\begin{array}{l}\text { Roswell Park Memorial Institute } \\
\text { medium }\end{array}$ & $\begin{array}{l}\text { Medio Roswell Park Memorial } \\
\text { Institute }\end{array}$ \\
\hline rRNA & Riosomal RNA & ARN ribosomal \\
\hline SE & Standard error & Error estándar \\
\hline SEM & Standard error of the mean & Error estándar de la media \\
\hline SF & Soluble fibre & Fibra soluble \\
\hline SFA & Saturated fatty acids & Ácidos grasos saturados \\
\hline SMCFA & $\begin{array}{l}\text { Short and medium chain fatty } \\
\text { acids }\end{array}$ & $\begin{array}{l}\text { Ácidos grasos de cadena corta y } \\
\text { media }\end{array}$ \\
\hline spp. & Specie & Especie \\
\hline SR & Similarity rate & Grado de similitud \\
\hline T1-3 & Trials 1 to 3 & Pruebas 1 a 3 \\
\hline T1a & Trial 1a & Prueba 1a \\
\hline T1b & Trial 1b & Prueba 1b \\
\hline TDF & Total dietary fibre & Fibra dietética total \\
\hline TNF & Tumor necrosis factor & Factor de necrosis tumoral \\
\hline TNF- $\alpha$ & Tumor necrosis factor alpha & Factor de necrosis tumoral alpha \\
\hline Th & T-helpers & T-cooperadores \\
\hline Th1 & Cellular immune response & Respuesta inmune celular \\
\hline Th2 & Humoral immune response & Respuesta inmune humoral \\
\hline Th 17 & Th 17 immune response & Respuesta inmune Th 17 \\
\hline TLRs & Toll like receptors & Receptores tipo toll \\
\hline UPV & Universidad Politécnica de Valencia & \\
\hline
\end{tabular}



Resumen 



\section{RESUMEN}

El objetivo de esta tesis doctoral ha sido estudiar la capacidad que tienen varios nutrientes de mejorar la salud intestinal de los gazapos. Para lograr este objetivo general, se llevaron a cabo tres objetivos principales.

El primer objetivo consistió en describir la evolución con la edad de la microbiota intestinal, el sistema inmune y la morfología de la mucosa tras el destete. Para ello se destetaron 100 gazapos de 20 camadas a los 26 d de edad con un peso de $429 \pm 57 \mathrm{~g}$ y se sacrificó 1 animal por camada a los 26, 31, 38, 45 y 52 d de edad. Se tomaron muestras de la mucosa intestinal y del apéndice para determinar la morfología de la mucosa y la expresión genética de las citoquinas/interleucinas TNF- $\alpha$, IFN- $\Upsilon$, IL-2, IL-6, IL8, IL-10 e iNOS (en íleon y apéndice). El perfil de la microbiota se estudió en el íleon y en una mezcla de ciego y cecotrofos. El peso relativo del ciego aumentó $(\mathrm{P}<0,05)$ desde los 26 hasta los 38 d, y tendió a disminuir y estabilizarse a los 45 y 52 días de edad. La longitud de las vellosidades intestinales y el número de células caliciformes en el yeyuno se redujeron a los 31 d en comparación con los gazapos recién destetados a los 26 d de edad. $(\mathrm{P}<0,05)$, mientras que no se observó ningún efecto en la profundidad de las criptas. A $38 \mathrm{~d}$, no se observaron cambios en las vellosidades, que mostraron valores similares a las determinadas en el destete, mientras que las criptas siguieron aumentando ligeramente (9\%). Entre los 38 y los 52 d de edad, la profundidad de las criptas y el número de las células caliciformes se incrementaron $(\mathrm{P}<0,05)$ sin producirse cambios en la longitud de las vellosidades. La evolución del íleon siguió un efecto cuadrático en la proporción de Firmicutes (valor máximo entre los 38 días de edad; $\mathrm{P}=0,002$ ), y Bacteroidetes (valor mínimo entre los 38 y los 45 días de edad, $\mathrm{P}=0$,003). Al destete, Firmicutes y Bacteroidetes representaron cada uno casi la mitad de las unidades taxonómicas operacionales (OTUs) detectadas en el ciego. A medida que aumenta la edad, Bacteriodetes $(\mathrm{P}<0,001)$ es sustituido por Firmicutes $(\mathrm{P}<0,001)$ que a los $52 \mathrm{~d}$ representa un $85 \%$ de la flora mayoritaria. La expresión relativa del TNF- $\alpha$ en el apéndice aumentó a los 26 y a los 31 d de edad $(\mathrm{P}<0,005)$. Por el contrario, tanto el IFN- $r$ en el apéndice y en el íleon, así como la IL-2 en el íleon incrementaron linealmente con la edad ( $\mathrm{P} \leq 0,01)$. En conclusión, tras el destete se produce un balance específico entre Firmicutes y Bacteroidetes en el íleon y en el ciego produciéndose cambios temporales en la morfología de la mucosa y en la respuesta inmune. 
El segundo objetivo fue determinar el efecto de la suplementación de la dieta con arginina y glutamina sobre la productividad de las conejas reproductoras y los gazapos así como sobre la salud intestinal de los gazapos. Para alcanzar este objetivo se llevaron a cabo tres pruebas diferentes. Todas las pruebas realizadas se desarrollaron utilizando las mismas dietas experimentales. Así se formuló una dieta control (C) que contenía 29,8 g de nitrógeno (N), 313 g de aFNDom por kg MS y 1,85 g de N digestible/ MJ de energía digestible (ND/ED) y se fabricaron otros 3 piensos añadiendo (en $\mathrm{g} / \mathrm{kg}$ ) 4 de arginina (Arg), 4 de glutamina (Gln) y una mezcla de un 4 de arginina y un 4 de glutamina (Arg + Gln) a la dieta control.

En el primer estudio se determinó si la suplementación de la dieta con arginina, glutamina o con una combinación de ambos influía sobre la digestibilidad, la composición corporal y los rendimientos productivos de las conejas reproductoras y sus camadas durante las tres primeras inseminaciones. Para ello se utilizaron 80 conejas nulíparas asignadas al azar a los piensos experimentales (20/tratamiento) antes de la primera inseminación. Tras cada parto se llevó a cabo la homogenización de las camadas dentro de cada tratamiento y las conejas fueron inseminadas 11 días después. A lo largo de los tres primeros partos se midieron la composición química y el contenido en energía de las conejas, sus rendimientos productivos, el crecimiento de las camadas y la producción de leche entre el nacimiento y el destete $(25 \mathrm{~d})$. La suplementación con amino ácidos incrementó el contenido en ND $(\mathrm{P}=0,015)$ y tendió a incrementar el ratio ND/ED en comparación con el grupo $\mathrm{C}(\mathrm{P}=0,077)$ dando lugar a un incremento de la ingestión del ND durante la lactación $(\mathrm{P}=0,004)$. En este periodo, el grupo Gln presentó una ingestión mayor de $\mathrm{ED}$ en comparación con los grupos $\mathrm{C}$ y $\operatorname{Arg}+\mathrm{Gln}(\mathrm{P}=0,038)$. El número total de gazapos nacidos por camada tendió a incrementarse en las conejas suplementadas con Arg y Gln, comparadas con los grupos $\mathrm{C}$ y $\operatorname{Arg}+\mathrm{Gln}(\mathrm{P}=0,095)$, aunque no hubo efecto de los tratamientos sobre el número de gazapos destetados $(\mathrm{P}=0,15)$. La suplementación individual con Arg y Gln incrementó el peso de las camadas a 20 y 25 d respecto a los grupos $\mathrm{C}$ y $\operatorname{Arg}+\mathrm{Gln}(\mathrm{P} \leq 0,021)$. La suplementación con los amino ácidos no afectó a la producción de la leche $(\mathrm{P}=0,16)$, aunque hubo una correlación positiva entre la ingestión de ED y ND ( $\mathrm{P}<0,001)$. No hubo efectos significativos de los tratamientos sobre el peso, la composición química y el contenido en energía de las conejas, aunque las conejas suplementadas con Arg o con Gln tendieron a tener un mayor contenido en energía en el momento de la tercera inseminación y al destete que aquellas de los grupos $\mathrm{C}$ y Arg+Gln 
$(\mathrm{P} \leq$ 0,099). La suplementación con amino ácidos no modificó la tasa de reposición de las conejas. En conclusión, la suplementación individual con Arg y Gln tuvo efectos positivos en el peso y el tamaño de la camada al nacimiento, pero no hubo efectos aditivos cuando se suplementó con la combinación de Arg+Gln.

En la segunda prueba se midió el crecimiento, la digestibilidad ileal y fecal así como la eficiencia del nitrógeno y la energía de los gazapos suplementados con arginina y glutamina desde la gestación y la lactación, a través de la suplementación de sus madres con las mismas dietas, y tras el destete recibiendo los mismos piensos suplementados con los amino ácidos. Los gazapos fueron destetados a los $25 \mathrm{~d}$ de edad y los rendimientos productivos se midieron hasta los $55 \mathrm{~d}$ de edad. En el ensayo 1, (T1a) los gazapos se alimentaron con los mismos piensos que recibieron sus madres durante todo el periodo experimental, mientras que en los ensayos T1b, T2 y T3 se alimentaron con las dietas experimentales desde los 25 hasta los 35 d de edad, y después con el pienso $\mathrm{C}$ hasta los $55 \mathrm{~d}$ de edad. Para el ensayo de digestibilidad se utilizaron 96 gazapos que fueron bloqueados por camada y asignados al azar entre los tratamientos. La composición de la canal y la eficiencia de utilización del nitrógeno y de la energía se midieron en 104 animales pertenecientes al ensayo T1a. Cuando los animales fueron suplementados con los piensos experimentales durante todo el cebo, la mortalidad fue similar para todos los tratamientos $(\mathrm{P}=0,92)$, sin embargo, los gazapos alimentados con glutamina durante el primer periodo (25-35 d de edad), tendieron a disminuir su mortalidad en el periodo global de cebo $(\mathrm{P}=0,10)$ en comparación con los gazapos no suplementados. Los tratamientos no afectaron a los rendimientos productivos de los gazapos independientemente del ensayo realizado $(\mathrm{P}>0,05)$. La digestibilidad ileal de la mayoría de los aminoácidos mejoró con la suplementación con los amino ácidos $(\mathrm{P} \leq 0,10)$. La digestibilidad fecal de la materia seca y del nitrógeno aumentaron $(\mathrm{P}<0,05)$ en los animales alimentados con los piensos Arg, Gln o Arg+Gln mientras que la digestibilidad fecal de la energía se incrementó en los gazapos suplementados con arginina o con glutamina $(\mathrm{P}=0,003)$. La digestibilidad fecal de la FND fue mayor con los piensos Gln y Arg+Gln ( $\mathrm{P}<0,001)$. La suplementación con arginina disminuyó la eficiencia del nitrógeno y de la energía ( $\mathrm{P}<$ 0,001) debido a que aumentó el consumo tanto de nitrógeno como de energía digestible $(\mathrm{P}<0,001)$ mientras que la retención de nitrógeno y energía en la canal fue similar independientemente de la suplementación. Además con la suplementación con arginina, las pérdidas de nitrógeno en la piel y las vísceras tendieron a aumentar $(\mathrm{P}=0,098)$ y 
aumentaron las pérdidas en orina $(\mathrm{P}=0,030)$ así como las pérdidas de energía en forma de orina + producción de calor $(\mathrm{P}=0,003)$.

En la tercera prueba se estudió si la exposición a la glutamina, la arginina o a la combinación de ambas desde la gestación y la lactación a través de la suplementación de sus madres con las mismas dietas, y tras el destete recibiendo los piensos suplementados con los amino ácidos, estimulaban sus crecimientos, el desarrollo del tracto digestivo y la respuesta inmune. Los gazapos fueron destetados a los $25 \mathrm{~d}$ de edad y alimentados con las mismas dietas experimentales que sus madres durante 10 días, hasta los 35 d de edad. Se determinó la translocación bacteriana a los nódulos linfáticos mesentéricos (NLM) a los 6 días de edad y la morfología intestinal de la mucosa, su actividad enzimática y el análisis fenotípico y funcional de los linfocitos intraepiteliales (LIE) del apéndice a los 6, 25 y 35 días de edad. No hubo diferencias significativas en los rendimientos productivos y la mortalidad entre los tratamientos, Sin embargo, los gazapos procedentes de camadas suplementadas con Gln tendieron $(\mathrm{P} \leq 0,10)$ a reducir tanto el número de bacterias aeróbicas como facultativas translocadas hacia los NLM. Además, los gazapos alimentados con Gln mantuvieron la longitud de las vellosidades intestinales al destete en comparación con las dietas no suplementadas $(\mathrm{P}<0,05)$. Las proporciones de linfocitos intraepiteliales $\mathrm{CD} 45^{+} \mathrm{CD} 4^{+}$y $\mathrm{CD} 45^{+} \mathrm{CD}^{+}$en el apéndice no se vieron afectadas por los tratamientos. Sin embargo, la suplementación con Gln al destete aumentó la expresión de la IL-2 y la IL-10, disminuyendo la expresión de la IL-6 de los linfocitos intraepiteliales en el momento del destete. En conclusión, a pesar de no haber un efecto sobre los rendimientos productivos y la mortalidad, la inclusión de $0,4 \%$ de Gln tuvo un efecto positivo manteniendo la longitud de las vellosidades intestinales e induciendo un perfil de citoquinas más moderado y una respuesta Th1-Th2 más equilibrada al destete. La suplementación con Arg o con Arg+Gln a las dosis seleccionadas en este estudio no rindieron ningún efecto beneficioso en las variables estudiadas.

El tercer objetivo de la tesis fue determinar el efecto de la inclusión de dos niveles de fibra soluble y dos relaciones de ácidos grasos n-6/n-3 sobre la productividad de las conejas reproductoras y los gazapos así como sobre la salud intestinal de los gazapos en crecimiento. Para alcanzar este objetivo se llevaron a cabo tres pruebas diferentes. Todas las pruebas realizadas se desarrollaron utilizando las mismas dietas experimentales. Se formularon cuatro piensos (BFS_Bn-6/n-3, BFS_An-6/n-3, AFS_Bn-6/n-3 y AFS_An- 
6/n-3) con dos niveles de fibra soluble (BF: 7,8 vs. AF: $14,4 \% \mathrm{MS}$ ) y dos ratios n-6/n-3 (Bn-6/n-3: 13,4 vs. An-6/n-3: 3,5).

En el primer estudio se determinó si la inclusión de dos niveles de fibra soluble y dos relaciones de ácidos grasos n-6/n-3 influía sobre la digestibilidad, la composición corporal y los rendimientos productivos de las conejas reproductoras y sus camadas durante las cuatro primeras lactaciones. Para ello se utilizaron 96 conejas nulíparas asignadas al azar a los piensos experimentales (24/tratamiento) antes de la primera inseminación. Tras cada parto se llevó a cabo la homogenización de las camadas dentro de cada tratamiento y las conejas fueron inseminadas 11 días después. A lo largo de los cuatro primeros partos se midieron la composición química y el contenido en energía de las conejas, sus rendimientos productivos, el crecimiento de las camadas y la producción de leche entre el nacimiento y el destete ( 25 d). La proporción total de conejas eliminadas disminuyó con la AFS respecto al grupo de BFS $(22,9$ vs. 50,0\%; $\mathrm{P}=0,005)$, tendiendo a disminuir en el grupo BFS cuando se incrementaba el ratio de n-6/n-3 y en el grupo de AFS cuando se disminuía el ratio n-6/n-3 (P = 0,059). El incremento del nivel de fibra soluble redujo ratio $\mathrm{PB} / \mathrm{ED}$ digestible $(4 \% ; \mathrm{P}<0,001)$ e incrementó la digestibilidad de todas las fracciones de la fibra $(\mathrm{P}<0,001)$. La reducción del ratio n-6/n-3 redujo la digestibilidad de la fibra dietética total en las conejas que recibieron BFS sin tener efecto en aquellas alimentadas con las dietas AFS $(\mathrm{P}=0,043)$. Los tratamientos no afectaron a la ingestión entre partos $(P=0,16)$, aunque la ingestión de $\mathrm{PB}$ digestible entre partos fue menor en el grupo AFS en comparación con el grupo BFS $(\mathrm{P}=0,003)$. No se observó ningún efecto relevante de los tratamientos sobre el número de gazapos nacidos totales, el peso medio de los gazapos al nacimiento o en el tamaño de la camada al destete, la fertilidad, la eficiencia alimenticia de las conejas, la producción de leche y la composición química y el contenido en energía de las conejas $(\mathrm{P} \geq 0,29)$. El peso medio de los gazapos al destete perteneciente a madres alimentadas con BFS_An-6/n-3 y AFS_Bn-6/n-3 disminuyó en un $6 \%$ en comparación con aquellas de los otros dos grupos ( $\mathrm{P}=0,030)$. La reducción del ratio n-6/n-3 en la dieta incrementó el contenido en grasa de la leche en un $12 \%$ sin afectar al contenido de proteína ni de MS $(\mathrm{P}=0,031)$. La proporción de ácidos grasos impares y de ácidos grasos saturados se incrementó en las conejas alimentadas con AFS en comparación con aquellas alimentadas con dietas con BFS $(\mathrm{P} \leq 0,037)$ sin observarse efecto del ratio n-6/n-3. La reducción del ratio n-6/n-3 redujo la concentración de C18:1n-9 en la leche (en un 19\%; P < 0,001) e incrementó la proporción de C18:3n-3 
(en un 306\%; P < 0,001). En conclusión, la fibra soluble redujo la tasa de reposición de las conejas sin verse afectado por el ratio n-6/n-3, mientras que ambos factores modificaron la composición de la leche y su perfil de ácidos grasos sin influir en la productividad de las camadas.

En la segunda prueba se estudió si la inclusión de dos niveles de fibra soluble y dos relaciones de ácidos grasos n-6/n-3 o la combinación de ambos influía sobre los rendimientos productivos, la composición corporal y la eficiencia de retención del nitrógeno y la energía en gazapos en cebo. Se utilizaron 40 gazapos/pienso destetados a 26 d de edad para determinar la composición corporal y de la canal mediante impedancia bioeléctrica a $\operatorname{los} 27,39,62$ y 69 d de edad. El incremento de fibra soluble redujo la mortalidad en el periodo global experimental (38,3 vs. 24,1\%; $\mathrm{P}=0,018)$, sin observarse ningún efecto del ratio n-6/n-3. La eficiencia alimenticia en el periodo global (26-62 d de edad) mejoró con el incremento de fibra soluble (en un 3,5\%; $\mathrm{P}=0,003$ ) y con la reducción del ratio n-6/n-3 (en un 2,3\%; $\mathrm{P} \leq 0,048$ ). El incremento de fibra soluble disminuyó el ratio de $\mathrm{PB}$ digestible/ED (en un 2,3\%; $\mathrm{P}=0,050$ ). Los gazapos alimentados con las dietas con Bn-6/n-3 tendieron a presentar menor contenido en grasa corporal y mayor proporción de energía al destete ( 26 d de edad), aunque al final del cebo (62 d de edad) tendieron a ser más pesados y a tener mayor contenido de grasa corporal y menor proporción de energía $(\mathrm{P} \leq 0,11)$. El incremento de fibra soluble y la reducción del ratio n-6/n-3redujo el nitrógeno digestible ingerido (en un 4\%; $\mathrm{P} \leq 0,030$ ). Sin embargo, la cantidad de nitrógeno retenido en el cuerpo o en la canal no se vieron afectados por los tratamientos $(P \geq 0,26)$. En consecuencia, el incremento de fibra soluble mejoró la eficiencia de retención del nitrógeno digestible tanto en el cuerpo como en la canal (en un 5,4 y 4,7\%, respectivamente; $\mathrm{P} \leq 0,034)$. Además, la reducción del ratio $\mathrm{n}-6 / \mathrm{n}-3$ incrementó la eficiencia de retención del nitrógeno digestible tanto en el cuerpo como en la canal (3,9 and 3,4\%, respectivamente; $\mathrm{P} \leq 0,043)$. Esta mejora de la eficiencia del nitrógeno estuvo asociada con una reducción de la excreción del nitrógeno en orina en el grupo AFS respecto al grupo BFS (en un 13\%; $\mathrm{P}=0,004$ ) y en el grupo $\mathrm{Bn}-6 / \mathrm{n}-3$ respecto al An-6/n-3 $(P=0,072)$. Los tratamientos no afectaron a la ingestión de la ED y a la retención de energía del cuerpo y la canal $(\mathrm{P} \geq 0,13)$. El incremento de fibra soluble mejoró la eficiencia de retención de la energía digestible en el cuerpo y la canal (en un $2,7$ y 3,0\%; P $\leq 0,042)$. La mejora en la retención de la energía digestible en la canal en el grupo de AFS se debió principalmente al deterioro observado en los gazapos 
alimentados con BFS_An-6/n-3 respecto a aquellos alimentados con la dieta BFS_Bn6/n-3 ( $\mathrm{P}=0,071)$. No hubo ninguna influencia de la fibra soluble sobre las pérdidas de energía en forma de orina y producción de calor, aunque tendieron a ser menores cuando disminuyó el ratio n-6/n-3 ( $\mathrm{P}=0,058)$. Las pérdidas en heces fueron menores con AFS que con BFS (en un 6,1\%; P < 0,001). En conclusión, el incremento de fibra soluble incrementó la supervivencia de los gazapos en cebo, sin ninguna influencia del ratio n6/n-3. Por el contrario, tanto el incremento de la fibra soluble como la reducción del ratio n-6/n-3 mejoraron la eficiencia de la energía digestible y la proteína retenida en el cuerpo y en la canal. No se encontraron efectos aditivos de ambos factores.

En la tercera prueba se estudió si la inclusión de dos niveles de fibra soluble y dos relaciones de ácidos grasos n-6/n-3 o la combinación de ambos influía sobre la digestión y la respuesta inmune de los gazapos tras el destete. Los gazapos utilizados provenían de conejas alimentadas con los mismos piensos descritos, y todos los gazapos recibieron los mismos piensos que habían consumido sus madres. Para determinar la digestibilidad fecal de los nutrientes se utilizaron 56 gazapos (14/tratamiento). Doscientos ocho gazapos fueron destetados a los 26 días de edad y sacrificados a los 39 d para recoger la digesta ileal y determinar así la digestibilidad ileal de los nutrientes, los pesos de los órganos digestivos, el pH cecal y la mucosa tanto del apéndice como del íleon para determinar la respuesta inmune. El incremento del ratio n-6/n-3 mejoró la digestibilidad fecal de la FDT y la fibra soluble únicamente de los gazapos alimentados con un nivel bajo de FS (P < 0,05). Los gazapos alimentados con altos niveles de FS tendieron a tener mayor digestibilidad ileal del almidón y mayor flujo de mucinas en comparación con aquellos gazapos alimentados con bajos niveles de FS $(\mathrm{P} \leq 0,064)$. El incremento de FS redujo la mortalidad entre los 26 y los $56 \mathrm{~d}$ de edad, mientras que no hubo diferencias cuando se administró una dieta común desde el destete hasta el final del cebo. El nivel de FS y el ratio n-6/n-3 tuvieron una menor influencia en la expresión de los genes relacionados con la inmunidad en el apéndice. Así, en el apéndice, la IL 8 mostró una menor expresión en los gazapos alimentados con los piensos Ln-6/n-3 y BFS $(\mathrm{P}=0,04)$ sin tener efecto en aquellos animales alimentados con AFS. La expresión de la IL-6 tendió $(\mathrm{P}=0,09)$ a mostrar un comportamiento similar. También, la expresión del TLR-4 disminuyó ( $\mathrm{P}=$ 0,03) en los gazapos alimentados con los piensos Ln-6/n-3. Los gazapos alimentados con piensos altos en FS mostraron una mayor expresión del gen MUC-13 ( $\mathrm{P}=0,046)$ y una menor expresión ileal de iNOS $(\mathrm{P}=0,050)$ que aquellos que recibieron las dietas bajas 
en FS. Por el contrario, la reducción del ratio n-6/n-3 incrementó la expresión ileal de IL2 , IL-10 IFN- $\gamma$ y TLR-2 $(\mathrm{P} \leq 0,028)$. 
Summary 



\section{SUMMARY}

The global aim of this thesis has been to study the capacity of several nutrients to improve the intestinal health status of rabbits. To accomplish with this general aim, three main objectives have been carried out.

The first aim was to describe the evolution of the rabbit intestinal microbiota, immune response and mucosa morphology after weaning. Rabbits from 20 litters weaned at $26 \mathrm{~d}$ of age were slaughtered at 26, 31, 38, 45 and $52 \mathrm{~d}$ of age (one rabbit per litter and day). Samples of intestinal mucosa and appendix were processed to determine jejunal mucosa morphology and gene expression of TNF- $\alpha$, INF- $\Upsilon$, IL-2, IL-6, IL-8, IL-10 and iNOS (in the ileum and appendix). The microbiota profile was studied in the ileal and in a mix of caecal digesta and soft faeces. The relative weight of the caecum increased $(\mathrm{P}<$ 0.05 ) from 26 to $38 \mathrm{~d}$, and tended to decrease and stabilize at 45 and $52 \mathrm{~d}$ of age. The villous height, and the number of goblet cells per villi decreased in rabbits of $31 \mathrm{~d}$ of age compared to still suckling rabbits of $26 \mathrm{~d}(\mathrm{P}<0.05)$, while no effect was observed in the crypt depth. At $38 \mathrm{~d}$ of age villous height and the number of goblet cells recovered their values and crypt depth increased $(\mathrm{P}<0.05)$. From 38 to $52 \mathrm{~d}$ of age crypt depth and the number of goblet cells increased $(\mathrm{P}<0.05)$ with no change on the villous height. A quadratic effect was found for the evolution in the ileum of the proportion of Firmicutes (maximal value at $38 \mathrm{~d}, \mathrm{P}=0.002$ ), and Bacteroidetes (minimal value between 38 and 45 d, $\mathrm{P}=0.003$ ). At weaning Firmicutes and Bacteroidetes represented each one around half of the caecal operational taxonomic units (OTUs) detected. The proportion of Firmicutes increased from 31 to $38 \mathrm{~d}$ of age, substituting the phylum Bacteroidetes that decreased in this period $(\mathrm{P}<0.05)$, leading to a positive or negative linear effect of age, respectively, on these phylum. In fact, from $38 \mathrm{~d}$ of age onwards Firmicutes was the dominant phylum accounting for $84 \%$ OTUs detected. The relative gene expression (fold change) of TNF $\alpha$ in the appendix was upregulated at 26 and $31 \mathrm{~d}$ of age $(\mathrm{P}<0.05)$, whereas in the ileum it peaked at $31 \mathrm{~d}$ of age $(\mathrm{P}<0.05)$. On the opposite, IFN- $\gamma$ in the appendix and ileum, and IL-2 in the ileum increased linearly with age $(\mathrm{P} \leq 0.01)$. In conclusion, after weaning there is a specific balance between Firmicutes and Bacteroidetes in the ileum and caecum and some temporary changes in the mucosa morphology and immune response.

The second objective was to determine the effect of dietary arginine and glutamine supplementation on the productivity of rabbit does and growing rabbits and intestinal 
health of young rabbits. To achieve this objective three trials were carried out. A Control diet was formulated containing $29.8 \mathrm{~g}$ nitrogen $(\mathrm{N}), 313 \mathrm{~g}$ aNDFom per $\mathrm{kg}$ DM and 1.85 $\mathrm{g}$ digestible N/MJ digestible energy (DN/DE), and another 3 diets were obtained by adding $(\mathrm{g} / \mathrm{kg}) 4 \% \mathrm{Arg}, 4 \% \mathrm{Gln}$ and a mixture of $4 \%$ Arg and $4 \%$ of Gln to the Control diet.

In the first trial was studied whether the dietary supplementation with arginine (Arg) and glutamine (Gln) or the combination of both (Arg+Gln) may influence the digestibility, body composition, and reproductive performance of rabbit does during the first three parturitions. Eighty nulliparous rabbit does were randomly assigned to the diets (20/diet) before the first insemination. After each parturition litter size was homogenized within each treatment and does inseminated $11 \mathrm{~d}$ later. Chemical composition and energy content of rabbit does and their performance, litter growth and milk production were measured between birth and weaning $(25 \mathrm{~d})$ along three parturitions. Amino acid supplementation increased the $\mathrm{DN}$ content $(\mathrm{P}=0.015)$ and tended to increase the $\mathrm{DN} / \mathrm{DE}$ ratio compared to the Control group $(\mathrm{P}=0.077)$ leading to an increase of digestible $\mathrm{N}$ intake during lactation $(\mathrm{P}=0.004)$. In this period, Gln group had a higher DE intake compared to Control and $\operatorname{Arg}+\mathrm{Gln}$ groups $(\mathrm{P}=0.038)$. Total number of kits born per litter tended to increase in rabbit does supplemented with Arg and Gln, compared to Control and Arg+Gln groups $(\mathrm{P}=0.095)$, but no effect of treatments on the number of weaned rabbits was observed $(\mathrm{P}=0.15)$. Single supplementation of $\mathrm{Arg}$ and Gln increased the weight of the litters at 20 and $25 \mathrm{~d}$ respect to Control and $\mathrm{Arg}+\mathrm{Gln}$ groups $(\mathrm{P} \leq 0.021)$. Amino acid supplementation did not affect the milk production $(\mathrm{P}=0.16)$, although it was positively correlated with the $\mathrm{DE}$ and $\mathrm{DN}$ intake $(\mathrm{P}<0.001)$. There were no significant effects of treatments on body weight, chemical composition and energy content of rabbit does, but does supplemented with Arg or Gln tended to have a higher body energy content at the third insemination and at weaning than those from Control and Arg+Gln groups $(\mathrm{P} \leq 0.099)$. Amino acid supplementation did not modify the replacement rate of rabbit does. In conclusion, the single supplementation of Arg and Gln had a positive effect on the weight of litters at weaning and litter size at birth, but no additive effect was observed for the combined supplementation of Arg and Gln.

In the second trial was studied the growth performance, faecal and ileal digestibility and nitrogen and energy efficiency in rabbits that were fed with arginine and glutamine supplementation during their pre-weaning period through their mother supplementation 
and after weaning receiving the amino-acids supplementated diets. Rabbits were weaned at $25 \mathrm{~d}$ of age and growth performances were measured and mortality were recorded daily until $55 \mathrm{~d}$ of age. In trial 1a (T1a) animals were fed with the same diet as its mother during all the fattening, whereas rabbits from T1b, T2 and T3 were fed with the experimental diets from day 25 to $35 \mathrm{~d}$, and with the $\mathrm{C}$ diet from 35 to $55 \mathrm{~d}$. Apparent ileal and faecal digestibility, were measured in 96 rabbits blocked by litter and assigned at random to the experimental diets. Carcass composition energy and nitrogen efficiency in fattening rabbits were measured in 104 animals of T1. When animals were supplemented with experimental diets during the whole experiment mortality was similar in all the diets $(\mathrm{P}$ $=0.92$ ), but rabbits fed with glutamine in the first period (25-35 d of age), tended to decrease its mortality in the whole fattening period $(\mathrm{P}=0.10)$ respect to those not supplemented. Dietary treatments did not affect growth performance in any trial (P > 0.05). Ileal digestibility of the most of amino acids increased with amino acid supplementation $(\mathrm{P}<0.10)$. Faecal digestibility of dry matter and nitrogen increased $(\mathrm{P}$ $<0.05$ ) in rabbits fed with Arg, Gln or Arg+Gln diets whereas, energy faecal digestibility increased $(\mathrm{P}=0.003)$ in rabbits from Arg and Gln groups respect to unsupplemented rabbits. Neutral detergent fibre faecal digestibility trend to be higher with Gln and Arg+Gln diets $(\mathrm{P}=0.11)$. Arginine supplementation decreased by $7.87 \%(\mathrm{P}<0.001)$ nitrogen efficiency and, by $6.8 \%$ ( $\mathrm{P}<0.001)$ energy efficiency due to the increase of the digestible nitrogen intake by $7.79 \%(\mathrm{P}<0.001)$ and $\mathrm{DE}$ intake by $8.4 \%(\mathrm{P}<0.001)$, whereas the nitrogen and energy carcass retention were similar independently of the amino acid supplementation. This led to a tendency to increase nitrogen losses as skin and viscera $(\mathrm{P}=0.098)$ and an increase in urine excretion (by 23\%; $\mathrm{P}=0.030)$, energy losses in faeces $(\mathrm{P}=0.060)$ and in urine + heat production $(\mathrm{P}=0.003)$.

The third trial studied whether the exposure to glutamine, arginine or their combination from pregnancy and lactation, through the maternal diet, to a post weaning supplemented diet, can stimulate litter performance, gut development and immune function. Rabbits were weaned at $25 \mathrm{~d}$ of age and fed the same experimental diet as their mothers for 10 additional days ( $35 \mathrm{~d}$ of age). Bacterial translocation to mesenteric lymph nodes (MLN) at $6 \mathrm{~d}$ of age and intestinal histology, enzymatic activity, phenotypical and functional analysis of intraepithelial lymphocytes (IEL) from the appendix were determined at 6, 25 and $35 \mathrm{~d}$ of age. No significant differences on animal performance or mortality rates were observed among dietary treatments. However, kits from rabbit does 
supplemented with Gln tended $(\mathrm{P} \leq 0.10)$ to reduce the translocation of total number of both aerobic and facultative anaerobic bacteria to the MLN. Also, rabbits fed the Gln supplemented diets maintained intestinal villous height at weaning compared to the nonsupplemented diets $(\mathrm{P}<0.05)$. The proportions of $\mathrm{CD} 45^{+} \mathrm{CD} 4^{+}$and $\mathrm{CD} 45^{+} \mathrm{CD} 8^{+}$IEL in the appendix were not affected by dietary means. However, in rabbits IEL at weaning dietary Gln significantly upregulated IL-2 and IL-10 and downregulated IL-6 expression. In conclusion, despite a lack of effect on performance and mortality the inclusion of 0.4 $\%$ Gln has a positive effect by maintaining intestinal villous height and inducing a cytokine profile with a more moderate and balanced Th1-Th2 response at weaning. The supplementation with Arg or Arg+Gln at the selected doses in this study did not report any beneficial effect on the analyzed variables.

The third aim was to determine the effect of dietary soluble fibre and n-6/n-3 fatty acid ratio on the productivity of rabbit does and growing rabbits and intestinal health of young rabbits. Three trials were carried out to achieve this objective. Four diets were formulated in a $2 \times 2$ factorial arrangement with two levels of SF (7.8 vs. 13.0, on DM basis; HSF and LSF) and two different n-6/n-3 fatty acids ratio (13.4/1 vs. 3.5/1). Levels of CP and NDF were 16.4 and 30.9 \% DM respectively, while the level of starch content was higher in low soluble fiber diets (22.4 vs. $18.3 \%$ DM).

In the first trial was studied whether the dietary supplementation with soluble fiber (SF) and the reduction of the n-6/n-3 fatty acid ratio or the combination of both influence the digestibility, body composition, and reproductive performance of rabbit does during the first three parturitions. Nulliparous does were used (24/diet), and they were inseminated $11 \mathrm{~d}$ after parturition. Chemical composition and energy content of rabbit does and their performance, litter growth and milk production were measured between birth and weaning ( $25 \mathrm{~d}$ ) along three parturitions, and milk composition and faecal digestibility were also recorded. The proportion of the does removed decreased in HSF respect to LSF groups (22.9 vs. 50.0\%; $\mathrm{P}=0.005)$ and it tended to increase in LSF groups when the n-6/n-3 ratio increased and in HSF diets when the n-6/n-3 ratio decreased $(P=$ 0.059). The increase of the level of SF reduced the digestible $\mathrm{CP} / \mathrm{DE}$ ratio (by $4 \%$; $\mathrm{P}<$ $0.001)$ and increased the digestibility of all fibrous fractions $(\mathrm{P}<0.001)$. The reduction of the n-6/n-3 ratio reduced the total dietary fibre digestibility in rabbit does fed LSF diets but it had no effect in those fed HSF diets $(\mathrm{P}=0.043)$. Treatments had no effect on ADFI among parturitions $(\mathrm{P}=0.16)$, but the digestible $\mathrm{CP}$ intake among parturitions was lower 
in HSF compared to LSF groups $(\mathrm{P}=0.003)$. Treatments had no a relevant effect on the total number of kits born, litter or average kit weight at birth or litter size at weaning, fertility, feed efficiency, total milk production and body chemical composition and body energy content $(P \geq 0.29)$. The average weight of kits at weaning from LSF_Hn-6/n-3 and HSF_Ln-6/n-3 groups decreased by 6\% compared with those from the other two groups $(P=0.030)$. The reduction of the dietary $n-6 / n-3$ ratio increased the milk fat content by $12 \% 5 \mathrm{~d}$ after parturition with no effect on protein and DM content $(\mathrm{P}=0.031)$. The proportion of milk odd fatty acids and SFA increased in rabbit does fed the HSF diets compared with those fed LSF diets $(P \leq 0.037)$ with no effect of the $n-6 / n-3$ fatty acid ratio. The reduction of the dietary $\mathrm{n}-6 / \mathrm{n}-3$ ratio reduced the milk $\mathrm{C} 18: 1 \mathrm{n} 9$ (by $19 \%$; $\mathrm{P}<$ 0.001 ) and increased the $\mathrm{C} 18: 3 \mathrm{n} 3$ proportion (by $306 \%$; $\mathrm{P}<0.001$ ). In conclusion, SF reduced the replacement rate of rabbit does with no effect of the $n-6 / n-3$ ratio, while both dietary factors modified milk composition and fatty acid profile with minor influence on litter productivity.

In the second trial was studied whether the dietary supplementation with soluble fibre (SF) and the reduction of the $n-6 / n-3$ fatty acid ratio or the combination of both influence the growth traits, body composition, energy and nitrogen retention efficiency in fattening rabbits. The increase of SF reduced the mortality in the whole experimental period (38.3 vs. $24.1 \% ; \mathrm{P}=0.018$ ), with no effect of the $\mathrm{n}-6 / \mathrm{n}-3$ ratio. The feed efficiency in the whole experimental period (26-62 d of age) improved with the increase of the level of $\mathrm{SF}$ (by $3.5 \% ; \mathrm{P}=0.003$ ) and with the reduction of the $\mathrm{n}-6 / \mathrm{n}-3$ (by $2.3 \% ; \mathrm{P} \leq 0.048$ ). The increase of SF decreased the ratio CP/DE (by $2.3 \%$; $\mathrm{P}=0.050$ ). Rabbits fed Ln-6/n3 diets tended to have less body fat and more body protein concentrations at weaning (26 $\mathrm{d}$ of age), but at the end of fattening (62 d of age) they tended to be heavier and to have more body fat and less body protein proportions $(\mathrm{P} \leq 0.11)$. The increase of SF and the reduction of the $n-6 / n-3$ ratio reduced the digestible nitrogen intake (by $4 \%$. $\mathrm{P} \leq 0.030$ ). However, the amount of nitrogen retained in the body or in the carcass was not affected by treatments $(P \geq 0.26)$. Consequently, the increase of dietary SF improved the retention of digestible nitrogen in the body and in the carcass (by 5.4 and $4.7 \%$ respectively; $\mathrm{P} \leq$ 0.001). Moreover, the reduction of the $n-6 / n-3$ ratio increased the body and carcass efficiency of digestible nitrogen retention (by 3.9 and 3.4\%, respectively. $\mathrm{P} \leq 0.017$ ). This improvement of the digestible nitrogen efficiency was associated with a reduction of the urinary nitrogen excretion in HSF respect to LSF groups (by $12.6 \% ; \mathrm{P}=0.004$ ) and in 
Ln-6/n-3 respect to Hn-6/n-3 groups (by $12.1 \%$; $\mathrm{P}=0.006$ ). In contrast, the increase of SF increased the faecal nitrogen excretion by $5.2 \%(\mathrm{P}=0.004)$, and this effect tended to be more pronounced for Ln-6/n-3 group $(\mathrm{P}=0.072)$. Treatments had no effect on DE intake and on body and carcass energy retention $(P \geq 0.13)$. The increase of SF improved the body and carcass DE retention efficiency (by 2.7 and $3.0 \%$. $\mathrm{P} \leq 0.042$ ). The improvement of retention of DE in the carcass in HSF groups was mainly due to the impairment observed in rabbis fed LSF_Hn-6/n-3 respect to those fed LSF_Ln-6/n-3 diet $(\mathrm{P}=0.071)$. There was no influence of SF on the energy losses as urine and heat production, but they tended to be lower when the $n-6 / n-3$ ratio decreased $(P=0.058)$. The faecal losses of energy were lower with the HSF than with the LSF diets (by $6.1 \%$. P < 0.001). In conclusion, the increase of SF improved the survival of fattening rabbits, but the reduction of the $n-6 / n-3$ ratio did not influence it. In contrast, both the increase of soluble fibre and the reduction of the $n-6 / n-3$ ratio improved the efficiency of the digestible energy and protein retained in the body and in the carcass. No additive effect of both factors was found.

In the third trial was studied whether the dietary supplementation with soluble fiber (SF) and the reduction of the n-6/n-3 fatty acid ratio or the combination of both influence the digestion and immune response in young rabbits after weaning. Rabbits came from multiparous rabbit does fed with the same diets described, and all rabbits used were fed with the same diet of their mother. Fifty-six rabbits (14/diet) of $26 \mathrm{~d}$ of age, were used to determine the nutrient apparent faecal digestibility. Two-hundred eight rabbits (56/treatment) weaned at $26 \mathrm{~d}$, were slaughtered at $39 \mathrm{~d}$ of age and ileal digesta collected to determine the nutrient apparent ileal digestibility and recovered the weight of digestive organs, caecal $\mathrm{pH}$ and ileal and appendix mucosa to determine the immune response. The reduction of soluble fibre improved the ileal and faecal digestibility of total dietary fibre (TDF; $P \leq 0.029$ ). The increase of the $n-6 / n-3$ ratio impaired the faecal TDF and soluble fibre digestibility only in rabbits fed low SF diets $(\mathrm{P}<0.05)$. Rabbits fed high SF diets tended to have a higher ileal starch digestibility and ileal flow of mucins compared with those fed low SF diets $(\mathrm{P} \leq 0.064)$. The increase of SF reduced mortality from 25 to $39 \mathrm{~d}$ of age, or until the end of fattening when a common commercial diet was offered from 39 to $56 \mathrm{~d}$ of age, whereas no differences were observed when a common diet was provided from weaning to the end of fattening. The level of SF and n- $6 / n-3$ ratio had a minor influence on the gene expression of immune related genes in the appendix. The 
appendix of rabbits fed with LSFn-6/n-3 diet showed an up-regulation for IL-8 ( $\mathrm{P}=0.040)$ compared with the other groups. The expression of IL-6 tended $(\mathrm{P}=0.093)$ to show a similar interaction. Also, the expression of TLR-4 decreased $(\mathrm{P}=0.037)$ in rabbits fed the Ln-6/n-3 diets. Rabbits fed HSF diets showed a higher ileal MUC-13 (P=0.046) and iNOS gene expression $(\mathrm{P}=0.050)$ than those fed LSF diets. In contrast, the reduction of the $n-6 / n-3$ ratio increased the ileal gene expression of IL2, IL10, IFN- $\gamma$ and TLR-2 (P $\leq$ $0.028)$. 

Chapter 1

Literature review and objectives 


\subsection{Introduction and objectives.}

The ban of antibiotics as growth promoters within the European Union and the reduced number of molecules allowed as therapeutic treatment has limited the use of the main and most efficient tool to control digestive disorders in rabbit farming. It has led to nutritionists not only to meet the required dietary nutrient profile to optimize rabbit performance, but also to investigate the possible interactions among ingredients/nutrients, gut barrier function and pathogens in order to optimize rabbit health. For this complimentary goal, it is necessary to increase the present knowledge about immune response and its interaction with intestinal microbiota and its evolution with rabbit age to develop more efficient nutritional strategies taken into account the dietary influence during pregnancy and lactation.

Epizootic rabbit enteropathy (ERE) is currently the main digestive disease in rabbit, representing a $71 \%$ of the total rabbit diseases. This digestive pathology is responsible of the $60 \%$ of the rabbit mortality in the fattening period with important reductions in feed efficiency and animal growth. The higher mortality and morbidity rates turns up during the 2-3 weeks after weaning.

Previous studies showed that different nutritional strategies might to limit ERE incidence by modifying different ingredients/nutrients, based on its effects on gut barrier function and rabbit performance and mortality. They are related to the level of insoluble and soluble fibre $(30-32 \% \mathrm{NDF},>3.7 \%$ ADL, $>21 \%$ particles larger than $0.3 \mathrm{~mm}$ and 1012\% NDSF. Gutiérrez et al., 2002; Nicodemus et al., 1999, 2006; Gómez-Conde et al., 2007 and 2009) and the level and type of protein (14-16\% CP, 0,5-1\% glutamine, and preference for sunflower and animal plasma proteins rather than soya, pea and potato proteins. Gutiérrez et al., 2002 and 2003; García-Ruiz et al., 2006; García-Palomares et al., 2010; Chamorro et al., 2007, 2010; Baylos et al., 2008).

However, these strategies do not solve the problem completely and further dietary modification may be requires looking for a synergetic effect among nutrients like functional amino acids (arginine and glutamine), soluble fibre and the n-6/n-3 ratio.

Besides, the nutritional strategies should not be restricted to the weaning period. It would be necessary to develop a wider approach taking into account prenatal and postnatal periods, and, according by rabbit doe nutrition. 
Consequently, this $\mathrm{PhD}$ Thesis tried to investigate the capacity of several nutrients to improve the intestinal health status of rabbits. To accomplish with this general aim, three main objectives have been carried out:

1. Study the microbiota and intestinal immune response evolution in rabbits after weaning.

2. Determine the effect of dietary arginine and glutamine supplementation on productivity of rabbit does and growing rabbits and intestinal health of young rabbits.

2.1. Productive performance and corporal condition of rabbit does and their litters through three consecutive cycles.

2.2. Growth performance and nitrogen and energy efficiency in rabbits that were fed with this supplementation during their pre-weaning period through their mother supplementation and after weaning receiving amino-acids supplementation diets.

2.3. Effect of this supplementation on intestinal health of young rabbits at different ages.

3. Determine the effect of dietary soluble fibre and n-6/n-3 fatty acid ratio on productivity of rabbit does and growing rabbits and intestinal health of young rabbits.

3.1. Productive performance and corporal condition of rabbit does and their litters thought four consecutive cycles, and determination of milk composition.

3.2. Growth performance, and nitrogen and energy efficiency in rabbits that were fed with this fibre soluble level and n-6/n-3 ratio during their pre-weaning period through their mother supplementation and after weaning receiving fibre soluble level and n-6/n-3 ratio diets.

3.3. Effect of soluble fibre level and n-6/n-3 fatty acid ratio on digestion and intestinal health of young rabbits. 


\subsection{Rabbit immune system.}

The gut is the place where occurs the digestion and absorption of nutrients, but also has an immune function through the gut associated lymphoid tissue (GALT) (Knight et al., 2000).

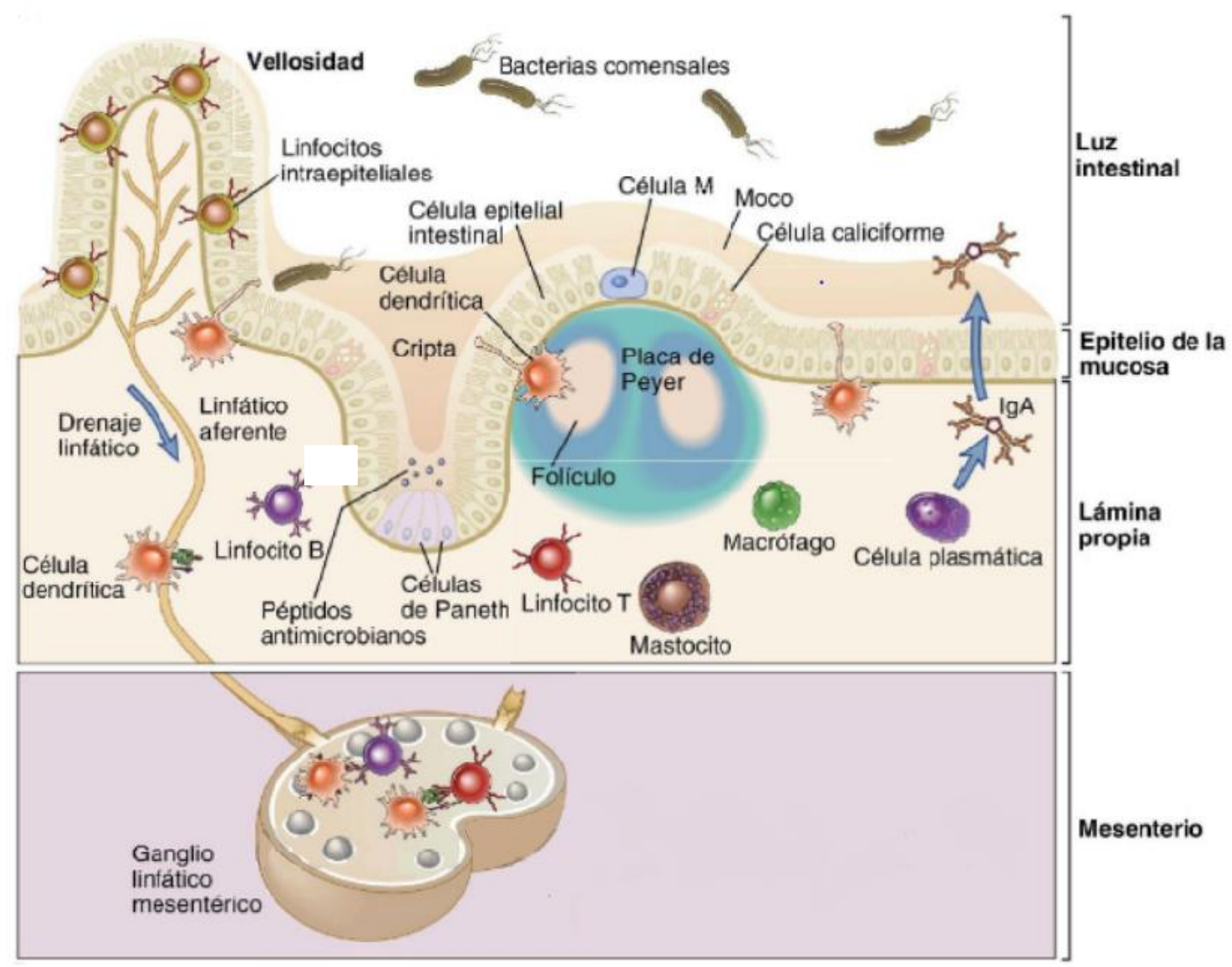

Figure 1. Digestive immune system. (Source: Abbas et al., 2014).

The GALT has a double function: it is responsible of neutralizing the possible pathogens and it protects the mucosa by regulating the inflammatory response. The immune system of the gut is constantly active, differentiating antigens from the diet and commensal bacteria and defending against pathogens (Calder and Kew 2002; Mowat, 2003). Thus, the usual response to diet antigens and commensal bacteria is the tolerance mechanism, known as oral tolerance, which, avoids the development of allergies to certain feeds and the inflammation and response (Mowat, 2003; Williams. 2012).

The GALT is separated from the intestinal lumen by an epithelial layer, involved in the response against the pathogenic microorganisms, in the tolerance development to commensal microorganism and in the antigen capture for its delivery to the adaptive immune gut system (Abbas et al., 2014). There are four main cell types constituting it: 
$\checkmark$ Enterocytes: their primary function is the terminal digestion and absorption of nutrients but they also secrete cytokines. Moreover, they have different cellular receptors, including the Toll like receptors (TLRs) that recognize the molecular patterns associated to pathogens but also limit inflammatory responses for commensal bacteria. Epithelial cells express a wide variety of TLR, like TLR 2, 4, 5, 6,7 and 9.

$\checkmark$ M cells: located in specific structures in the dome above the lymphatic tissues. They are antigen collectors.

$\checkmark$ Paneth cells: located in the background of the crypts. They secrete various antimicrobial peptides.

$\checkmark$ Goblet cells: located in the top of the intestinal villi. They are responsible of the synthesis and secretion of mucins (Allen et al., 1982) and bioactive peptides.

Between the epithelial cells, there are intraepithelial lymphocytes that are the first line of defense from the mucosal infections and tend to have cytotoxic and regulatory activity.

Mucins secreted by goblet cells, covers the epithelial layer forming the mucus layer that is going to protect epithelial layer from mechanical, chemical, enzymatic agents and bacterial aggressors and their toxins (Deplancke and Gaskins, 2001). Moreover, it serve as a matrix of the antimicrobial substances produced by the epithelial cells (Abbas et al., 2014). Mucus layer is predominantly composed by mucins (glycoproteins constituted by a protein linked to sugar chains of variable length) that constituted a hydrated gel compound by two layers: one external less dense that is colonized normally by bacteria, and other one internal, denser and linked to the epithelium, in order to prevent bacterial colonization (McGuckin et al., 2011). Moreover, the apical surface of the epithelial cells is covered by protein mucins linked to the membrane like MUC1 and MUC13. These mucins linked to the membrane are combined with several glycosphingolipids to form a macromolecular dense layer called glycocalyx (McGuckin et al., 2011; Abbas et al., 2014).

Under the epithelial layer there is a connective tissue layer called lamina propria that contain blood vessels, lymphatic vessels and lymphatic tissue associated the mucus (Abbas et al., 2014). In the latter can be found isolated cells (like macrophages and dendritic cells, innate lymphoid cells, T lymphocytes, B lymphocytes, natural killer cells) and antibodies (immunoglobulins). The most common immunoglobulin produced is IgA, 
which function favor the development of commensal bacteria and limit the growth of pathogens (Carabaño et al., 2008).

Beside the GALT is formed by:

$\checkmark$ Peyer's patches: distributed along intestine have the structure of the lymphoid follicles. They are separated from the intestinal lumen by a monolayer of intestinal cells and $\mathrm{M}$ cells (enterocytes specialized in the laminar antigen uptake). They own a germinal center that contain B lymphocytes, T helper lymphocytes, macrophages and dendritic cells (Mowat, 2003). Other region called dome, is located between the follicles and the epithelium situated above, and contains B and T lymphocytes, macrophages and dendritic cells.

$\checkmark$ Mesenteric lymphoid nodes: are the largest lymph nodes in the body located in the intestinal mesentery. In them is developed the primary response.

$\checkmark$ Vermiform appendix: located in the distal part of the caecum forming a structure with sac form (Mage et al., 2006). In rabbits, the appendix is the larger lymphoid organ and comprises practically half of the lymphoid tissue associated to the mucosa (Dasso and Howell, 1997). In it is developed the primary response (Pospisil and Mage, 1998) and later, it acts like a secondary lymphoid organ participating in the proliferation of B lymphocytes

$\checkmark$ Sacculus rotundus is at the junction between ileum and caecum, is bigger than the Peyer's patches and contains a high number of lymphoid follicles.

It is generally considered that the organized GALT (Peyer's patches, vermiform appendix and sacculus rotundus) are the inductors centers of the immune response, where part of the cells of the intestinal immune system are made and where the immune response begins, while the diffused GALT (lamina propria) as a effector of the immune response (Mowat, 2003; Burkey et al., 2009).

Functionally, the immune system can be divided into innate (or natural) immune system and adaptive (specific or acquired) immune system.

\subsubsection{Innate immunity.}

It is the first line of defense against pathogen microorganisms and its activity is not enhanced by such exposure. Innate immunity is involved in preventing entry of infectious agents into the body and with their rapidly elimination if they enter (Calder and Kew., 2002). It is mediated in part by the physical and chemical barrier provided by the 
epithelial cells and the mucus that secrete. Moreover, epithelial cells are held together by epithelial tight junctions that open and close all the time in response to a variety of stimuli (e.g. dietary state, humoral and neuronal signals inflammatory mediators), and play a critical role in the para-cellular permeability (Arrieta et al., 2006).

In this way, several stimuli such as cytokines (IL-1, IL-4, IL-6, IL-9, IL-13, tumoral necrosis factor $[\mathrm{TNF}]$ and interferon type I), neutrophil products and microbial adhesive proteins increase the mucin gene expression and change their composition from neutral to acid (for this, sugar terminal chains are sulfated or sialylated) to be more resistant against the degradation (Abbas et al., 2014). In this sense, commensal bacteria also have the ability to regulate the synthesis, composition and use of mucins and antimicrobial peptides (Kelly et al., 2005), but little is known about the quantitative and qualitative balance compatible with an improvement of intestinal health. Thus, Bacteroides, a significant genus in humans and rabbits, seems to have mucolytic properties (Hill, 1986; Marounek et al., 2000; Sirotek et al., 2003). Innate lymphocyte cells produce IL-17 and IL-22 cytokines that potentiate the mucus barrier function stimulating the mucin production and increase the hermetic epithelial union and favors the $\operatorname{Ig} \mathrm{A}$ transport towards the intestinal lumen (Abbas et al., 2014).

Enterocyte's toll like receptors recognize molecular patterns associated to pathogens and generate signals that promote inflammatory and antiviral responses.

Once the pathogen cross the epithelial layer, is eliminated directly by toxic chemicals released by phagocytes or by toxic proteins released by natural killer cells or can be phagocyted by macrophages situated in the lamina propria. However, at the same time, these macrophages secrete anti-inflammatory cytokines, like IL-10.

\subsubsection{Adaptive immunity: the gut associated lymphoid tissue.}

It involves the specific recognition of antigens on pathogens, discriminating 'nonself' from 'self' (Calder and Kew, 2002). This immunity has a memory, such that if an antigen is encountered again, the response is faster and stronger than the initial response (Calder, 2001). 


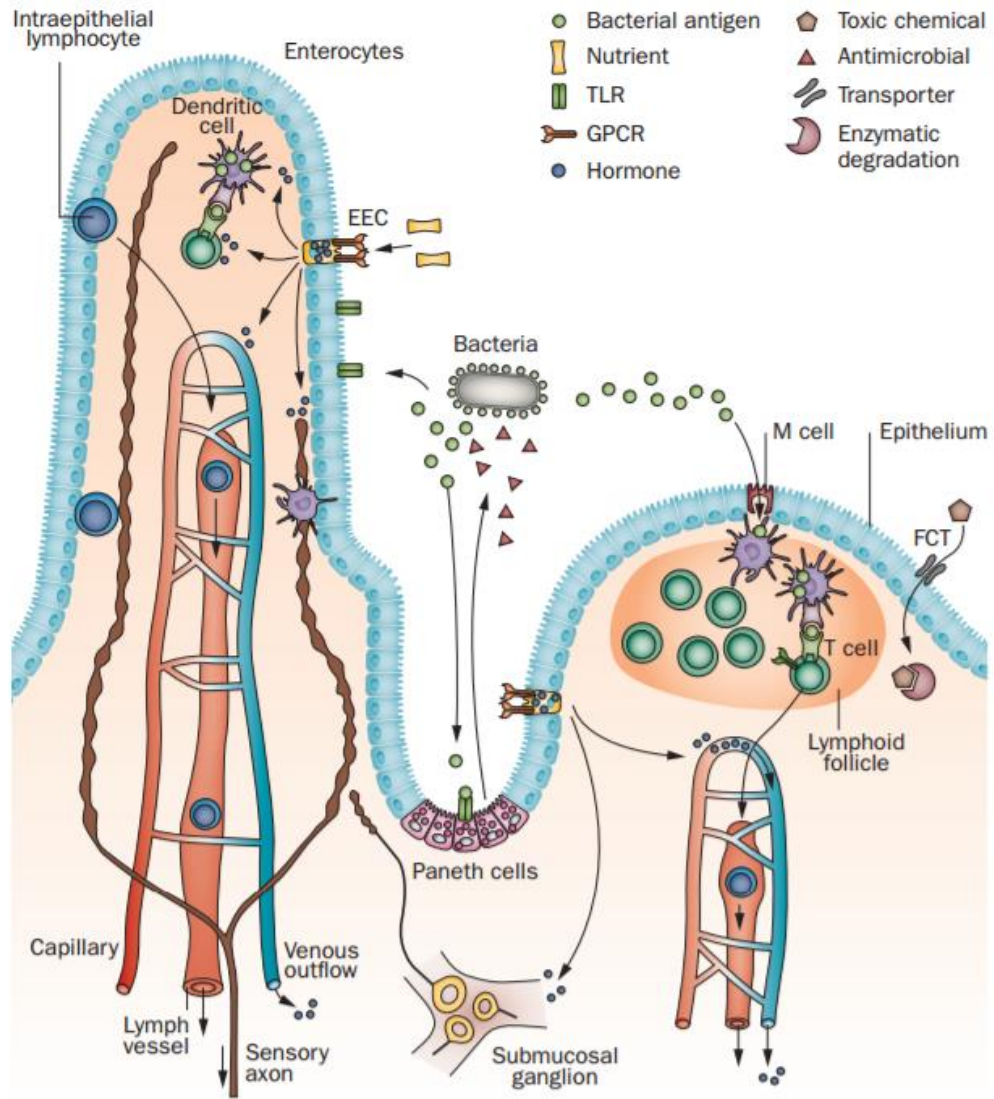

Figure 2. Sensory system at the luminal interface. (Source: Furness et al., 2013).

The are several antigen catchment mechanism., Some bacteria antigens can cross the mucosal epithelium because it is not completely impervious where they are sampled by the antigen presenting cells (macrophages and dendritic cells). Bacteria antigens are also detected by pattern-recognition receptors, including TLRs on Paneth cells and enterocytes. Dendritic cells of the lamina propria extend processes through tight junctions of the intestinal epithelial cells. However, the principal way is through $\mathrm{M}$ cells (located in the follicular associated epithelium or in the Peyer patch) which are responsible of transport the antigens from the intestinal lumen to the dendritic cells. Presenting antigen cells carry the antigens to B and $\mathrm{T}$ cells areas located into the Peyer patch or can travel through the lymph up to the mesenteric lymphoid nodes were they interact with the naïve lymphocytes, conditioning the activation and differentiation of B and $\mathrm{T}$ lymphocytes through secretion of cytokines and the antigen presentation through the histocompatibility complex $(\mathrm{MCH})$. Once activated, both $\mathrm{B}$ and $\mathrm{T}$ lymphocytes proliferate in number, differ to acquire it definitive effector function and travel to the lamina propria where they respond to the pathogens. B lymphocytes are going to differentiate into plasmatic cells that are the responsible of the antibody production, mainly $\operatorname{IgA}$, which are going to avoid the union of the microorganism to the receptors situated in the epithelial cells. B lymphocyte differentiation can occurs directly or via T lymphocyte (Mowat, 2003). T lymphocytes are characterized because only can recognize the pathogen-derived peptide fragment bound to certain proteins termed major histocompatibility complex (MHC) which is 
termed MHC-peptide complex. There are two types of MHC (I and II). Major histocompatibility complex I binds intracellular peptides from viruses or certain bacteria and MCH II binds peptides from pathogens that have been phagocytosed by macrophages or endocytosed by antigen-presenting cells (macrophage, dendritic cells, B-lymphocytes). When $\mathrm{T}$ lymphocytes are activated they can be differentiated towards cytotoxic lymphocytes $\left(\mathrm{CD}^{+}\right)$which recognize MHC I and interact with infected cells to which they lisan, or towards helper lymphocytes $\left(\mathrm{CD}^{+}\right)$that recognize $\mathrm{MCH}$ II and stimulate an immune response. While $\mathrm{CD} 4^{+}$lymphocytes are usually in the lamina propria or in the appendix, $\mathrm{CD}^{+}$lymphocytes are in the lamina propria as intraepithelial lymphocytes (Dasso et al., 2000; Burkey et al., 2009).

After antigen recognition, the presenting antigen cells are going to induce different T helper lymphocytes depending on the cytokines secreted by modulating the immune response secreting their own cytokines that will activate an cellular (Th1) or humoral (Th2) response.

Interleukin 12 (IL-12) and interferon-gamma (IFN-Y) synthesis induce the differentiation of $\mathrm{CD}^{+}$towards a Th1 response. Th1 lymphocytes are going to migrate to the infectious sites and produce mainly IL-2, IFN- $\Upsilon$ and tumoral necrosis factor-alfa (TNF- $\alpha$ ), and mediate in the immune cellular response against infections produced by intracellular pathogens (viruses, bacteria and protozoa) increasing the phagocytosis by macrophages and neutrophils.

IL-4 synthesis by the dendritic cells results in differentiation towards to a Th2 response. Th2 lymphocytes remain in the lymphoid tissues, secreting principally IL-4, IL-5 IL-10 and IL-13. They are related with the humoral response activating B lymphocytes and with the defense against helminths and arthropods and they are important in allergic reactions.

Balance between the immune system Th1 and Th2 responses is it not clear yet, but it seems that commensal bacteria, especially some genders, can mediate in the Th2 response activation (Kelly et al., 2005). Th1 generation and the consequence IFN- $\gamma$ production, inhibit the Th2 response generation and this, trough IL-4 and IL-10 production, avoid the Th1 development.

IL-6 and IL-23 cytokines causes the differentiation towards a Th17 response. Th17 lymphocytes secrete principally IL-17, IL-21 IL-22 and IL-10 and are related with the 
protection against extracellular pathogens, both bacterial and fungal (Zhu and Paul, 2009).

\subsubsection{Rabbit immune response in health and disease.}

In healthy rabbits, Gutiérrez (2009) showed that cytokine expression level were higher in the vermiform appendix and in the Peyer Patches than in the ileal mucosa. In vermiform appendix, IL-10 and IL-6 reported a higher expression whereas in the Peyer Patches was IFN- $\gamma$. Rabbits with ERE did not present a different cytokine expression in the vermiform appendix, while in the Peyer Patches there was an increase of the TNF- $\alpha$ and IL-6 expression, and because of their pro-inflammatory activity, they are effective in the activation of phagocytic cells that act against the infections produced by intracellular pathogens agents (Stow et al., 2009). In the intestinal mucosa of ERE affected rabbits, IFN- $\gamma$, TNF- $\alpha$ and IL-6 expression level increase. Thus, in animals that present ERE seems that Th1 response is the dominant one. Studies carried both in vivo and in vitro using macrophages cellular models have shown that the Clostridium perfringens enterotoxin produces an increase of IFN- $\gamma$, TNF- $\alpha$ and IL-6 synthesis (Wallace et al, 1999). This pathogen seems to be directly involved in ERE development (Pérez de Rozas et al., 2005; Marlier et al., 2006; Szalo et al., 2007). Furthermore, the cellular response mediated by the cytokines from the Th1 complex results in the activation of $\mathrm{CD}^{+}$ lymphocytes, which has been related with the increase of mortality by ERE (GómezConde et al., 2007).

\subsection{Rabbit development with the age.}

\subsubsection{Digestive tract.}

Rabbits start solid feed intake around $18 \mathrm{~d}$ of age decreasing gradually milk intake (Lebas, 1970). Thus, it has been showed that solid feed intake at $25 \mathrm{~d}$ of age is approximately of $12 \mathrm{~g} /$ day per rabbit in litters of 10 rabbits and milk intake could be up to $35 \mathrm{~g}$ /day, depending of the litter size (Scapinello et al., 1999). Thus, weaning occurs in a stressful transition time (between 25 and $35 \mathrm{~d}$ of age), because of the nutritional transition from milk to solid food and the events related to housing and litter management. Moreover, these changes are linked to an incomplete development of the digestive and absorptive capacity of the digestive tract (De Blas et al., 1999a). 
Some studies show that there is usually a positive relationship between weaning age and rabbit viability (Feugier et al., 2006; Romero et al., 2009), although this is not always consistent among studies (Garrido et al., 2009). Thus, Mendez et al. (1986) observed that weaned rabbits had a lower weight gain respect to suckling rabbits at the same age, being this trend more pronounced with early weaning, although these differences disappeared during the whole fattening period. In addition, Ferguson et al. (1997) found that rabbits weaned at $14 \mathrm{~d}$ of age, reduced their feed intake and weight gain, increasing the mortality compared to $28 \mathrm{~d}$ of age-weaned rabbits. Thereby, Lebas (1993) observed that mortality decreased in rabbits weaned at $35 \mathrm{~d}$ of age compared with $25 \mathrm{~d}$ of age-weaned rabbits. This is in agreement with Gidenne and Fortune-Lamothe. (2002) who found an increase in the mortality in rabbits weaned at $23 \mathrm{~d}$ compared to 32 d of age-weaned rabbits from 32 to 45 d of age. However, Prud hon and Bel. (1968) did not detect any differences in the final body weight and in the mortality when the weaning age was ahead from 32 to $14 \mathrm{~d}$ of age or to $18 \mathrm{~d}$ of age (Piattoni et al., 1999). Xiccato et al. (2000) did not detect any effect in the mortality when rabbits were weaned at 21, 25, 28 or $35 \mathrm{~d}$ of age and Garrido et al. (2009) observed a higher mortality in rabbits weaned at $35 \mathrm{~d}$ of age compared with animals weaned at $25 \mathrm{~d}$ of age.

Weaning (from 21 to $35 \mathrm{~d}$ of age), seems not have an important influence on the morphology and enzymatic activity in the upper tract (stomach and small intestine) (Gallois et al., 2005 and 2008). The jejunal villous length increased from 28 to $49 \mathrm{~d}$ age independently of the weaning age (Gallois et al., 2005). However, other authors found villous atrophy in jejunal mucosa after weaning (Gutiérrez et al., 2002; Campín et al., 2003; Gómez-Conde et al., 2007), that could drive a lower absorption capacity, higher endogenous nitrogen losses and a reduction of brush border enzyme activity. This villous atrophy might depend on the weaning diet used. In this context, Álvarez et al. (2007) and Gómez-Conde et al. (2007) showed that an increase of the dietary soluble fibre resulted in an increase of the villous length and a reduction of the crypt depth.

On the other hand, weaning stimulates the maturation of the hindgut (caecum and colon) (Carabaño et al., 1998). Caecum develops faster than the rest of digestive system from 3 to 7 weeks of age (Carabaño et al., 1998) and it is associated with the solid feed intake, the development of the microbial fermentation and the caecotrophy appearance (Lebas and Laplace., 1972). In this stage, caecum are filled by digesta and microbiota and reach a peak that supposes about $9 \%$ of body weigh at 8 weeks of age (Yu and Chiou, 
1997). In this way, Gutierrez et al. (2002) found that weaning has a high influence on the empty caecum and caecal content, and that suckling rabbits at $35 \mathrm{~d}$ of age had smaller caecum than those weaned at $25 \mathrm{~d}$ of age (by 50\%). In this period, the caecum is being colonized by a metabolic active commensal microbiota (Padilha et al., 1995; Combes et al., 2011) that interacts with the immune system development (Mage et al., 2006).

\subsubsection{Intestinal microbiota.}

The microbial colonization seems to begin when the neonate pass through the birth canal and continues due to the microbiota present in the maternal milk (Houghteling and Walke., 2015). In humans, several studies have shown that milk is a continuous source of commensal, mutualistic and potentially probiotic bacteria to the infant gut (Martín et al., 2004; Fernández et al., 2013). This microbiota came from the digestive tract and achieves the reproductive tract and the mammary gland through translocation as it was observed in mice and women (Gavin and Ostovar, 1977; Welsh and May, 1979; Heikkila and Saris, 2003; Martín et al., 2004; Donnet-Hughes et al., 2010). Moreover, after birth, environmental microbiota plays an important role in the neonatal gut colonization and complete the microbial stimulus that is essential for the maturation of the immune system (Hanson and Lanning, 2008). In rabbits, these environmental conditions are those present in the nest consisting in abdominal rabbit doe fur and surrounding plant materials. After birth, the doe only visit the nest to suckle her young only once per day (Hoy and Selzer, 2002) for a short time (3 to 5 min; Zarrow et al., 1965; González-Mariscal, 2007) and during this time it has been observed a maternal hard faecal excretion in the nest (Moncomble et al., 2004; Kovács et al., 2006). The amount of faecal pellets excreted by the does in their nest is very variable among does and increases linearly up to 6-10 day post-parturition, decreasing regularly up to 17 day post-parturition (Combes et al., 2014; Nicodemus et al., 2015) and the litters begin to bite these hard faeces 10 days after parturition (Nicodemus et al., 2015). Thus, Kóvacs et al. (2006) demonstrated that Bacteroides colonization of the caecum during the first $10 \mathrm{~d}$ of life occurred at a reduced rate in pups that had not access to the doe's faeces. In fact, a limited access to them delays caecal microbial colonization, increasing the mortality during fattening period, whereas their stimuli, enhanced microbial colonization improving the health during the fattening period (Combes et al., 2014). Althought this effect is not always observed (Nicodemus et al., 2015).Furthermore, it, has been observed in suckling rabbits a significant translocation of bacteria from digestive tract to the mesenteric lymph nodes (MLN), 
especially during the first days of lactation (Urao et al., 1996) but its biological significance is not clear.

After weaning, rabbits only have access to solid feed, which means a change in the substrate used by the microbiota, that modifies the quantity and the profile of the intestinal microbiota. In addition, microbial implantation vary along the intestinal tract and evolve with the age (Smith, 1965; Gouet and Fonty. 1973; 1979). The main colonization site is the caecum (Gouet and Fonty; 1973). The soft faeces intake permits to obtain amino acids, vitamins and energy of bacterial origin (Carabaño et al., 1998) obtained from the fermentation of the residue coming from the small intestine (Carabaño et al., 2006). However, this colonization process could be altered and derive in different digestive pathologies, that usually have a multifactorial origin (Peeters et al., 2000). Thus, some studies has demonstrated that Clostridium perfringens spores could be a consequence of rabbit epizootic enteropathy and could be associated with the mortality caused by this disease (Marlier et al., 2006; Dewreé et al., 2010; Szalo et al., 2007., Pérez de Rozas et al., 2005; Romero et al., 2009).

Intestinal microbiota is very complex and has a great diversity and in the last years. Several studies that use culture-independent analysis based on 16S rRNA genes demonstrated that the rabbit`s caecum harbors 80-96\% of unknown species (Abecia et al., 2005; Monteils et al., 2008) confirming that bacteria is the predominant population as was observed by Gouet and Fonty (1979) and Boulharouf et al. (1991) using culture techniques. Bennegadi et al. (2003) showed that at $28 \mathrm{~d}$ of age, archaea accounted for $22 \%$ of the culture microbial community. The bacterial community in adult rabbits, is constituted by a $93 \%$ of Firmicutes and a $4 \%$ of Bacteroides (Monteils et al., 2008). Baïerl et al. (2014) showed that other phylum present in $40 \mathrm{~d}$ old rabbits were Verrumicrobia and Tenericutes. Within Firmicutes, in the order of Clostridiales, the most abundant families were Ruminococcaceae and Lachnnospiraceae while in the order Bacteroidales, Rikenellaceae was the most abundant family (Baïerl et al., 2014). Combes et al. (2011) described how caecal microbiota evolved from a simple and unstable community after birth into a complex and climax community in sub-adult rabbis. Other authors reported the presence of yeast (Peeters, 1988) and protozoa (Forsythe and Parker, 1985; Lelkes, 1986). 


\subsubsection{Immune system.}

The development of immune system begins in the foetal period by the generation of naïve immune cells in the bone narrow and liver. Newly generated B cells migrate to GALT, particularly the appendix and sacculus rotundus, where they proliferate (Rhee et al., 2004; Hanson and Lanning, 2008). At birth, the immune system of neonates is immune-deficient, with lower capacity of generation of both the different subsets of lymphocyte and active immune response against pathogens compared to adult animals (Jecklova et al., $2007 \mathrm{a}, \mathrm{b}$ ). During the first two weeks of age there is a decrease of the neonatal B cell repertoire and slightly increase of T lymphocytes. Consequently, in this period, the capacity of immune system is greatly compromised and the survival of kits depends on passive immunity acquired from the mother (via placenta and calostrum) and the protection of the milk. The latter contains immunoglobulins and determined bactericide compounds, as peptides (growth factors, etc) or short chain fatty acids (Skrivanová et al., 2005). In this way, it has been observed that milk intake protect temporarily the rabbit against intestinal pathogens like Escherichia coli O-103 that causes colibacillosis (Gallois et al., 2007) or Clostridium perfringens (Romero et al., 2009) that is implicated in ERE. The primary antibody repertoire develops between the 3rd and 8th week of age when GALT lymphocytes proliferates and diversificates especially in the appendix (Knight and Crane., 1994). In this process, the intestinal microbiota in the appendix plays a crucial role on the primary antibody generation and differentiation (Perey and Good, 1968; Stepanková et al. 1980; Hanson and Lanning, 2008). Intestinal microbiota also promotes B cell expansion and GALT development (Rhee et al., 2004). Thereby, Perey and Good (1968), showed that follicular development was arrested in rabbit appendices that had been surgically ligated at birth to prevent microbial colonization. When the ligated appendix was reconnected with the intestinal lumen, follicular development was restored. Stepanková et al. (1980) found that appendices from germfree rabbits were markedly underdeveloped and contained reduced members of lymphocytes. Recent studies have shown that GALT development and primary antibody repertoire not only relies on the presence of bacteria in the gut, but on the interaction with specific members of the normal gut microbiota (Lanning et al., 2000). Thus, Rhee et al. (2004) found that the combination of Bacteroides fragilis and Bacteroides subtilis promoted GALT development and somatic diversification of the primary antibody repertoire. 
Rabbit weaning is linked to an immaturity of immune response against pathogens, resulting in a higher susceptibility digestive disorders that becomes the major cause of mortality and morbidity of the rabbits around the weaning (Gallois et al., 2005). For this reason, the post-weaning period (from 25 to $42 \mathrm{~d}$ ) is characterized in rabbits by an immature immune system and the rearrangement of the intestinal microbiota, which make them more sensitive to digestive diseases. Weaning seems to accelerate maturation of immune system, increasing the proliferation and differentiation of lymphocytes that lead to a specialized immune response, but symptoms of immature are still present two weeks after weaning at $25 \mathrm{~d}$ of age (Campín et al., 2003; Carabaño et al., 2008). Although the inflammatory lesions are limited in rabbits with ERE (Licois et al., 2006; Dewrée et al., 2010), intestinal mucosa of weaned rabbits affected with ERE showed a higher expression of pro-inflammatory cytokines (IL-6, TNF- $\alpha$ ), and iNOS (Menoyo et al., 2010). These results seems to agree with the increase of CD8+ lymphocytes and the decrease of IL-2 receptors observed in lamina propia of intestinal samples of rabbits fed low soluble fibre level, and higher mortality rate, which might suggest a cell mediated immune response (Th1) in ERE affected rabbits (Gómez-Conde et al., 2007). These authors partially reversed these effects including moderate levels of soluble fibre in the diet detecting also relevant effects on mucosa functionality and intestinal microbiota.

Accordingly, immune system modulation is a complex issue due to the several interactions between immune function, intestinal microbiota, animal maturation, diet, nutrient dose and feed management, resulting in wide variables results among experiments.

\subsection{Nutritional strategies.}

\subsubsection{Arginine and glutamine.}

Arginine family is constituted by glutamine, glutamate, proline, aspartate, asparagine, ornithine, citrulline and arginine. All of them are interconvertible via complex inter-organ metabolism in most mammals (Wu et al., 2007). These amino acids are usually abundant in plant and animal tissue proteins (Wu and Morris, 1998). They are part of the amino acids called functional (Wu, 2009) that are regulators of key metabolic pathways that are necessary for maintenance, growth, reproduction and immunity in organism (Fu et al., 2005; Rhoads et al., 2006), therefore maximizing efficiency of food 
utilization, enhancing protein accretion, reducing adiposity, and improving health (Suenaga et al., 2008).

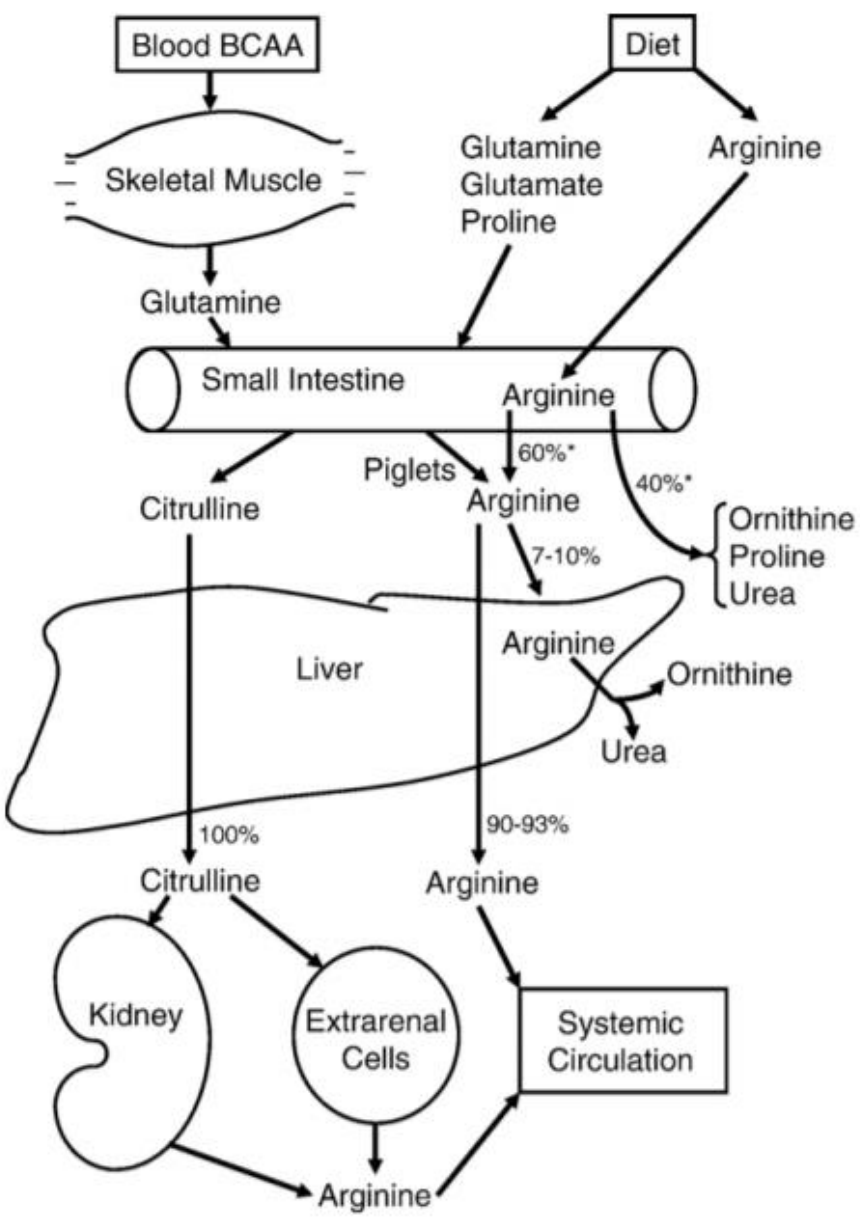

Figure 3. Inter-organ metabolism of arginine family (source: Wu et al., 2007).

\subsubsection{Reproduction.}

Arginine is used by many cells as a precursor for the synthesis of several important metabolic molecules including nitric oxide (Wu and Morris, 1998; Kim et al., 2007) via nitric oxide synthase and polyamines through the path of the ornithine decarboxylase (ODC) (Wu and Morris, 1998). In rabbit does, nitric oxide induced follicle rupture by the stimulation of prostaglandins (Yamauchi et al., 1997), and during follicle growth, the concentration of some amino acids such as arginine and tryptophan also increased (Hong and Lee, 2007). In addition, nitric oxide is the major endothelium-derived relaxing factor (Wu and Meininger, 2002) that plays an important role in vasodilatation (Bredt and Snyder, 1994; Moncada and Higgs, 1995) and regulates the blood flow through the hematoplacentic barrier, promoting the transferred of nutrients and $\mathrm{O} 2$ from the does to 
the kits (Bird et al., 2003). Feeding free arginine diets to pregnant rats or inhibiting nitric oxide synthesis resulted in an increase of the fetal resorptions, intrauterine growth retardation, perinatal mortality and a decrease of the number of live fetuses (Greenberg et al., 1997). In sows, it has been shown that the concentration of arginine in the uterine fluids during early gestation increased compared to maternal uterine plasma levels $(\mathrm{Wu}$ et al., 1998). This rise coincides with the time that the development of the placenta is faster (Wu et al., 2005) and suggest that both nitric oxide and polyamines are key regulators of angiogenesis and embryogenesis as well as of the placental and fetal growth (Reynolds and Redmer, 2001; Wu et al., 2004a). It results in an increase of blood and nutrient flow to the uterus producing more fetal survival and litter size (Reynolds and Redmer, 2001; Mateo et al., 2007; Berard et al., 2009). Arginine supplementation in gilts during early gestation (around $0.8 \%-1 \%$ and 14-28 d pregnancy) improved fetal survival (Berard and Bee, 2010) and increased the number of piglets born +1 with no effect on their average birth weight (Ramaekers et al., 2006). However, when arginine supplementation (1\%) was from day 30 of pregnancy to parturition it increased more the number of piglets born alive (+2) and their live weight (by 24\%; Mateo et al., 2007). In rats, the dietary supplementation with $1.3 \%$ arginine through the pregnancy ( $21 \mathrm{~d}$ of age) or between 1 and $7 \mathrm{~d}$ of pregnancy increased embryonic survival and birth litter size by 30\% (Zeng et al., 2008).

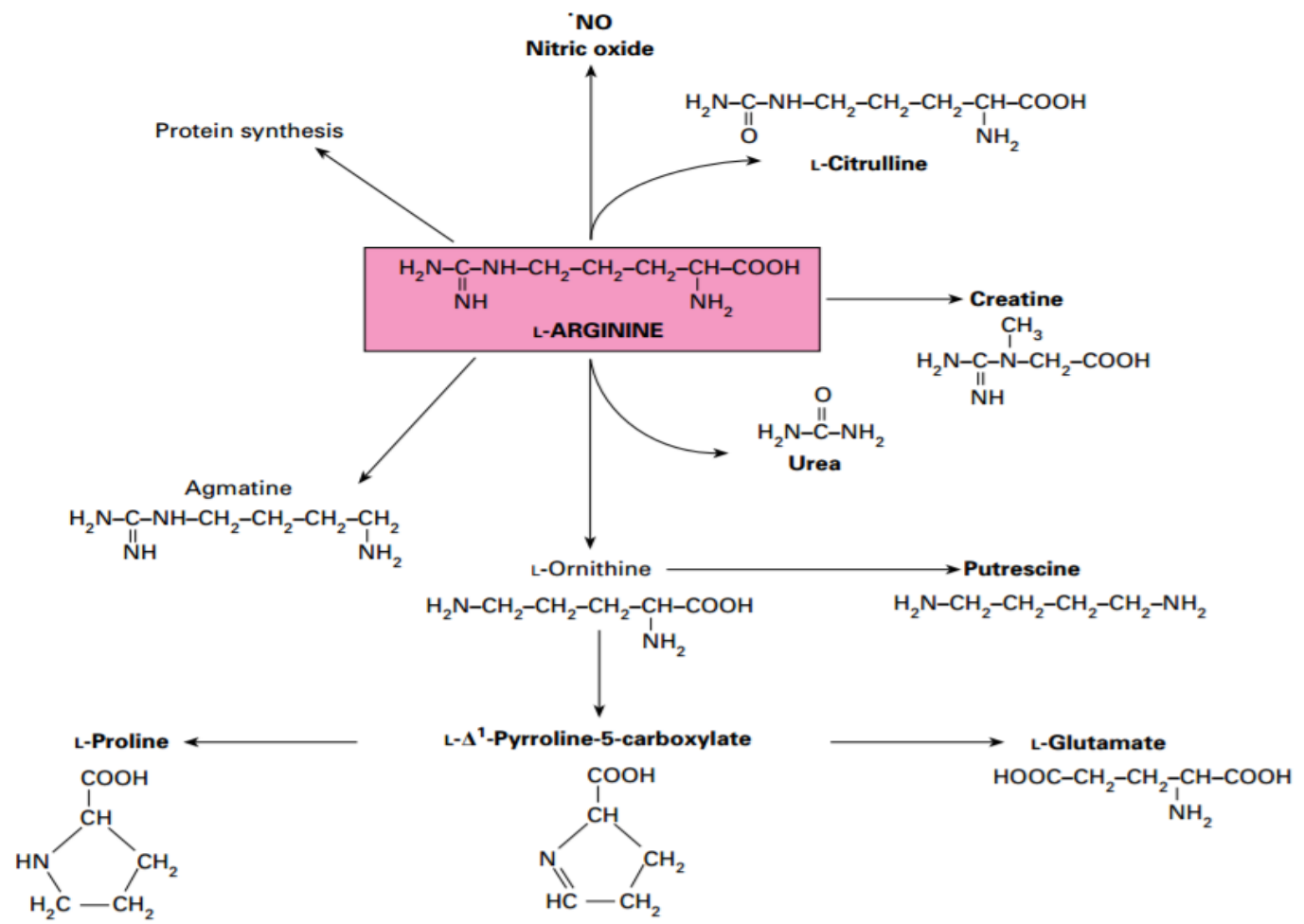

Figure 2. Metabolic fates of arginine in mammalian cells (source: Wu and Morris, 1998). 
Glutamine is the most abundant free $\alpha$-amino acid in plasma, fetal fluids (Wu et al., 1996) and milk (Wu and Knabe, 1994; Newsholme and Calder, 1997; Self et al., 2004). Glutamine is catabolised via glutaminolysis pathway to yield primarily glutamate (Field et al., 1994; Wu, 1996; Newsholme et al., 1999) which is present at higher concentration in pre-ovulatory ovarian follicular fluid (Józwik et al., 2006). It is one of the amino acid most abundant in pig follicular fluid but it is not altered by the change in follicle size (Hong and Lee, 2007). In pregnant gilts, glutamine is uptaked by the uterus due to the abundant amino acid in both uterine (Gao et al., 2009) and fetal (Wu et al., 1996) fluids, playing an important role in fetal nutrition and growth. It is the highest amino-acid uptake from the uterus in comparison to other amino acids (Wu et al., 1999). Moreover, it is also one of the majority amino acids found in the milk in sows, but it seems that its uptake by the porcine mammary glands does not meet the requirements for milk protein synthesis (Li et al., 2009). The supplementation of lactating sows diet with $1 \%$ glutamine increased its concentration in milk and enhanced piglet growth and survival (Wu et al., 2011).

\subsubsection{Intestinal health.}

Arginine and glutamine, among other essential amino acids, have a relevant role in growth and immunity because they are important regulators in different metabolic pathways (Wu et al., 2007). Under hypermetabolic states (e.g. inflammation, endotoxin infection, etc.) dietary supplementation with those amino acids helped to preserve intestinal mucosa structure and function, and to support normal immune response (Duggan et al., 2002; Ziegler et al., 2003). This has stimulated the interest and promoted research to use these amino acids in farm animals aiming to enhance health and production, especially during stressful periods as weaning. Weaning stress, associated with villous atrophy and immunosuppression, also increased the metabolism of arginine and glutamine in the intestinal epithelial cells of pigs (Wu et al., 1994; Flynn and Wu, 1997) and enhanced its requirements. Reduced feed intake during the early weaning period may exacerbate these deficiencies leading to bacterial translocation, gut atrophy, mucosal shedding and weight loss. Supplementation with arginine and glutamine appear to reverse these effects by enhancing total gut weight and preventing villous atrophy (Ewtushik et al., 2000). Inflammation and infection change the nutritional requirements, particularly of proteins and amino acids. In these circumstances, the organism may redirect the flux of nutrients to the tissues implicated in inflammatory and immune responses at the cost of those needed for growth (Le Floc'h and Séve, 2000). 
Experimental results suggest that the profile of amino acids required for the immune system differs substantially from those for growth (Reeds et al., 1994; Klasing and Calvert, 2000).

Arginine plays a key role in the metabolism of amino acids via the urea cycle, enabling the disposal of the nitrogen excess from the amino acids that cannot be used for anabolic purposes. Moreover, increase cell size and protein synthesis (Naomoto et al., 2005), it is essential for the release of growth hormones (Wu et al., 2007), and it is the precursor for the nitric oxide which is catabolized by the nitric oxide synthase. Nitric oxide is a key regulator of the immunity response, and for polyamines synthesis which are essential in tissues that are actively synthetizing proteins, but also act as a mediator in the histological development of enterocytes (Piva et al., 2002). The inducible isoform of the nitric oxide synthase (iNOS), is produced in macrophages, hepatocytes, in the vascular smooth muscle cells and in the endothelia in response to endotoxins, cytokines and other inflammatory factors (Tapiero et al., 2002), that could improve the intestinal health state. In humans, there is clinical evidence suggesting that arginine participates in the regulation of inflammation and enhances the immune response of patients suffering injury, surgical trauma, malnutrition or sepsis (Suchner et al., 2002). In piglets, dietary supplementation with arginine improves their immune status (Tan et al., 2007). A positive effect of dietary arginine supplementation against Eimeria spp. infection has also been reported in chicks (Allen, 1999; Kidd et al., 2001). Several authors observed that oral supplementation with $150-200 \mathrm{mg} / \mathrm{kg} /$ day of arginine and $150-200 \mathrm{mg} / \mathrm{kg} / \mathrm{day}$ of glutamine together resulted in certain beneficial additive effects (Kul et al., 2009; Zhou et al., 2012). Particularly, growing rabbits fed with diets supplemented with $1 \%$ of glutamine and $0.5 \%$ of arginine tended to improve growth performance, reducing the presence of Clostridium spp. and Helicobacter ssp. in the caecum and in the ileum (Chamorro et al., 2010). Ex vivo experiments suggest that giving arginine and glutamine together decrease the production of pro-inflammatory cytokines (Lecleire et al., 2008). Otherwise, there are metabolic and age-depending differences between species amino acids requirements especially for arginine. In this way, previous works in young rabbits showed that arginine requirements were particularly high compared to adult animals (Adamson and Fisher, 1976), and higher than in other mammalian species including human, pig and rat (Adamson and Fisher, 1973). 
Glutamine plays an important role in the metabolism of the intestinal mucosa, because it is necessary for the synthesis of glycoproteins that are secreted by the intestinal mucosal cells (Wu et al., 2001; Wang et al., 2006), maintaining intestinal barrier integrity and functionality ( $\mathrm{Wu}, 1998)$. In this way, the dietary supplementation with $1 \%$ of glutamine enhanced jejunal villi length during the first week after weaning in earlyweaned piglets (Wu et al., 1996). Furthermore, in apparent healthy rabbits, there are a trend to reduce lesions caused by developing oocyst (Eimeria spp.) in the villi of the jejunum (Chamorro et al., 2010). Moreover, several studies have demonstrated beneficial effects of supplying glutamine on preventing the bacterial translocation in diverse experimental models of challenged animals by reducing intestinal permeability (Chun et al., 1997; White et al., 2005). In this context, glutamine provides nitrogen for the synthesis of amino sugars, playing a critical role on intestinal mucins synthesis and hence in the maintenance of the passive barrier that limits bacterial colonization of intestinal mucosa (Khan et al., 1999) and on the maintenance of the tight junctions (Panigrahi et al., 1997; Li et al 2004). Glutamine also is absorbed by the small intestine, representing the major energy source for enterocytes (Wu et al., 1998), being essential for proliferation of cells (Rhoads et al., 1997; Curi et al., 2005) including intraepithelial lymphocytes and macrophages (Wu, 1996; Yoo et al., 1997) and for the synthesis of other non-essential amino acids as nucleotides. Furthermore, the role of glutamine as an immunomodulatory and anti-inflammatory is well-recognized (Van der Hulst et al., 1997; Newsholme et al., 1999). All the diverse cells of the immunity system including monocytes, macrophages, lymphocytes and neutrophils appear to be dependent on glutamine for their functionality (Newsholme et al., 1999), especially during disease. Moreover, glutamine reduced the pro-inflammatory response, reducing the expression of IL-6 and IL-8 and increasing the IL-10 anti-inflammatory response in the gut (Coeffier et al., 2001, 2003). Glutamine is also essential in the glutathione synthesis, which is the most abundant antioxidant in the small intestine (Wu et al., 2004b) and increased the expression of genes that prevent oxidative stress (Wang et al., 2008a). In growing rabbit's supplementation with 1\% glutamine, decreased fattening mortality and promoted a modification in the intestinal microbiota decreasing the frequency of Helicobacter spp. in the ileum and caecum and Clostridium spp. in the ileum (Chamorro et al., 2010). The supplementation of glutamine has also proved to be effective in calves using an Escherichia coli model (Brooks et al., 1997) and in broiler challenged with Eimeria maxima (Yi et al., 2005). However, there are some studies showing no effects of glutamine supplementation in other disease 
models (Naylor et al., 1987; Drackey et al., 2006). The effectiveness of glutamine may depend on whether the digestive insult challenges the immune system or not.

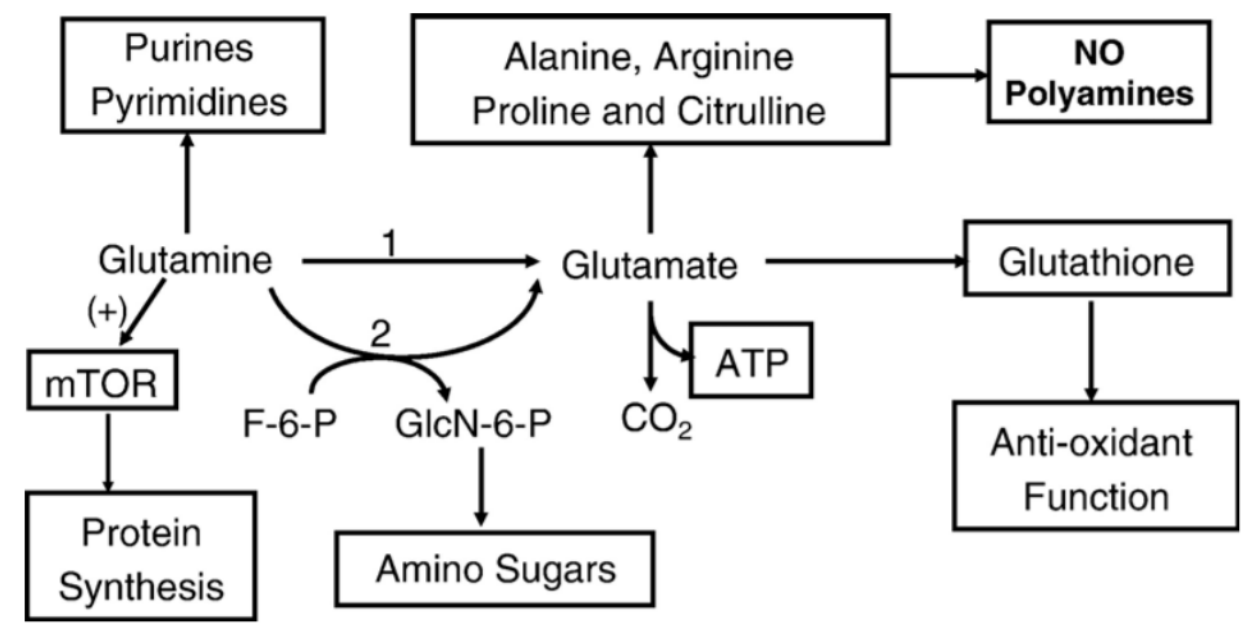

Figure 3. Possible mechanisms responsible for the beneficial effect of glutamine on intestinal barrier function and growth. Abbreviations: F-6-P, fructose-6-phosphate; GlnN-6-P, Nacetilglucosamine-6-phosphate. The symbol (+) denotes activation. (source: $\mathrm{Wu}$ et al., 2007)

\subsubsection{Soluble fibre.}

Soluble fibre comprises the non-starch and non-neutral detergent fibre polysaccharides. The main components that are considered part of the soluble fibre fraction are pectin substances, $(1 \rightarrow 3)(1 \rightarrow 4)$ - $\beta$-glucans, fructans and gums (Hall, 2003). It is a minor, heterogeneous and highly degradable fraction of the total dietary fibre (Trocino et al., 2013a). In rabbit diets, the increase of soluble fibre is based on the inclusion of pulps (beet, apple or citrus) whose principal components are hemicelluloses and pectin that are the more readily digestible cell-wall carbohydrates (Van Soest et al., 1991). Within pulps, most diets in rabbits include sugar beet pulp to increase the level of soluble fibre. The level of soluble fibre recommended is around $12 \%$ in the diet during the growth period, essentially after weaning (Trocino et al., 2013a). Consequently, increasing the inclusion of dietary sugar beet pulp resulted in increasing level of soluble fibre and fermentable insoluble fibre due to the low degree of lignification of its neutral detergent fibre fraction.

\subsubsection{Reproduction}

In rabbit does, the inclusion of soluble fibre in the diet, reduced their feed intake and, as a consequence, the digestible energy and crude protein intake. Moreover, milk production was reduced with the inclusion of soluble fiber in the diet, resulting in a lower feed intake and weight of their litters at weaning (Martínez-Vallespín et al., 2011). 


\subsubsection{Productive traits.}

The increase of soluble fibre in post-weaning diets usually has no effect on average daily gain but reduced feed intake improving feed conversion ratio (Carabaño et al., 1997; Falcao e-Cunha et al., 2004; Gómez-Conde et al., 2007; Martínez-Vallespín et al., 2011), although growth rate may be also improved (Trocino et al., 2013a). This reduction in the feed intake with the increase of soluble fibre in the diet could be related with an increase of the caecal contents (García et al., 2002; Gómez-Conde et al., 2009; Martínez-Vallespin et al., 2013) due to the digesta accumulation and to the increment of intestinal viscosity (Volek et al., 2007). In addition, the inclusion of soluble and fermentable fibre in the diet decreased the caecal $\mathrm{pH}$ and increased the total concentration of volatile fatty acids (Fraga et al., 1991; Falcao e-Cunha et al., 2004; Trocino et al., 2013a; Martínez-Vallespín et al., 2013), although it is not always observed (Carabaño et al., 1997).

Several studies showed that soluble fibre reduce the mortality in rabbits during the fattening period (Martínez-Vallespín et al., 2011; Trocino et al., 2013a). However, Gidenne. (2015) did not find relation between soluble fibre and mortality, which might be due to the data management and/or statistical analysis applied to integrate the information of studies. In addition, the level of sugar beet pulp inclusion is negatively related with the mortality (Abad, 2015), although it is still not clear if these effects depend only of their soluble or insoluble fermentable fraction or both fractions.

\subsubsection{Digestion.}

Dietary fibre, and therefore soluble fibre, only can be digested trough microbial fermentation in the digestive tract (De Blas et al., 1999b). Some components of soluble fibre are degraded in the stomach and in the small intestine by the pectinase activity, which is the main fibrolytic enzyme, whose presence in these segments of the intestinal tract can be explained by the caecotrophy (Marounek et al., 1995). At ileum, uronic acid, that is one of the components of pectins, showed the best ileal digestibility compared to the other monomers (Carabaño et al., 2001). In this way, Abad-Guamán et al, (2015) found that the ileal digestibility of soluble fibre calculated as TDF-aNDFom-cp increased with the level of soluble fibre. The high digestibility of soluble fibre in the ileum can be explained by the existence of a wide type of ileal microbiota (Gómez-Conde et al., 2007; 2009) and by its hydrolysis and solubilization (Abad-Guamán et al., 2015). 
The main site for soluble fibre fermentation seem to be the caecum, because its shows the higher microbial activity and the longer mean retention time (Gidenne et al., 2010). The, caecal microbial population secretes majority enzymes capable of degrading principally pectins and hemicelluloses (Marounek et al., 1995; Gidenne et al., 2000; 2002; Falcao-e-Cunha et al., 2004). Moreover, fibre sources has a significant effect on the caecal enzymatic activity value to the different amount and type of fibre that reaches the caecum. The soluble fiber level, affected caecal microbiota probably by modifying the amount and type of substrate reaching the caecum (Gómez-Conde et al., 2009; Abad-Guamán et al., 2015). Falcao e-Cunha et al. (2004), showed that sugar beet pulp based diets increased caecal pectinolytic and cellulolytic activities. The xylanolytic activity was not influenced by sugar beet pulp inclusion and it was lower than the pectinolytic activity and higher that the cellulolytic one. It agrees with the increase in the digestion efficiency of the fibre and with the increase of microbial activity with the level of pectins substances in the diet (García et al., 2000), similar to the introduction of sugar beet pulp in the diet (Trocino et al., 2013a). These results are parallel to the faecal digestibility of the corresponding dietary fibre constituents in rabbits. Hemicelluloses showed a higher digestibility than cellulose (46 vs. 27\%) (Gidenne et al., 2010) although the relative contents of digestible hemicellulose in the diet might vary depending on the source of the fibre used (Trocino et al., 2013a). Therefore, increasing the levels of sugar beet pulp as source of soluble fibre with low lignified (insoluble fibre) and with a high hemicellulose to cellulose ratio has often been associated with an increase NDF faecal digestibility, improving digestibility and energy value. In recent studies, the apparent faecal digestibility of soluble fibre has been determined showing a range from 69.7 to $95.1 \%$ being on average $84.9 \%$ (Trocino et al., 2010, 2011, 2013b; Abad-Guamán et al., 2015). In all the cases, the soluble fibre was determinated by the difference between TDF-aFNDom-cp.

\subsubsection{Intestinal health.}

The inclusion of soluble fibre in the diet in substitution of insoluble fibre, improved the structure (villous height/crypt depth) and functionality (greatest sucrose activity) of small intestinal mucosa and the immune response after weaning (Gómez-Conde et al., 2007). Furthermore, soluble fibre has a protective effect upon the mucosa that favors an immune response (Gómez-Conde et al., 2007). This positive effect might be due to a higher expression of IL-2 and a trend to show a higher activation of T lymphocytes $(\mathrm{CD} 25+\mathrm{CD} 25+)$ and increasing the T cytotoxic lymphocytes (CD8+). Moreover, it could 
be also related with the modulation of caecal microbiota (Gómez-Conde et al., 2007; 2009), reducing the frequency of profile compatible with Clostridium perfringens, and the trend to reduce opportunistic pathogens as Campilobacter spp both in the ileum and in the caecum (Gómez-Conde et al., 2007). At ileal level, El Abed et al. (2013) showed that the soluble fraction of sugar beet pulp favored different microbial population compared to the insoluble sugar beet pulp fraction whereas in the caecum, microbial populations were similar between the different fractions of sugar beet pulp.

More recently, it was reported that rabbits fed with sugar beet pulp (at the same age) showed higher villi height/crypt depth ratio than those fed with sunflowers hulls and straw (El Abed et al., 2011). These authors also found that the animals fed with the soluble fraction of sugar beet pulp (pectin) or with insoluble fraction of sugar beet pulp, showed intermediates values between sunflowers hulls and straw and sugar beet pulp diets. Therefore, it seems that the beneficial effect on intestinal morphology is an additive effect of both soluble and insoluble fibre fractions of the sugar beet pulp. However, Trocino et al. (2013b) in rabbits at $38 \mathrm{~d}$ of age did not found any differences while in $45 \mathrm{~d}$ old rabbits Álvarez et al. (2007) observed a trend to improve their mucosa morphology when soluble fibre increased. In older rabbits (51-56 d of age), there were any differences (Xiccato et al., 2008, 2011; Trocino et al., 2010, 2011). These results suggest that mucosal morphology might depend on the sampling site (jejunum vs. ileum), age and the health status of the animals (Gallois et al., 2005; Trocino et al., 2013a). In rats, the inclusion of pectin in diets also increased the villous height and crypt depth, thus suggesting that it led to a mucosa hyperplasia in the small intestine, which might be mediated trough the generation of short-chain fatty acids (Pirman et al., 2007). In contrast, the inclusion of pectin in weaning diets for pigs decreased villous height, crypt depth and the area of mucins in the crypts of the small intestine, whereas the feeding with high insoluble fibre improved gut morphology by increasing villi length and mucosal enzymatic activity (Hedemann et al., 2006). These results evidence the different effects of soluble fibre depending on the animal, which might be related to the differences in the intestinal physiology and/or intestinal microbiota profile.

Mucin secretion also can be influenced by the diet. In pigs, the inclusion of insoluble fibre in the diet enhanced mucus secretion (Montange et al., 2004). Meanwhile, the relationship between intestinal mucin secretion and soluble dietary fibre has not been fully elucidated. Satchithanandam et al. (1990) found that supplementation in rats with 
$5 \%$ citrus fibre in a purified diet produced an increase of mucin secretion in the stomach, small intestine and colon. According to Ito et al. (2009), goblet cell number in the jejunum and ileum increased the secretion of mucin proportionally to the molecular weight of the source of soluble fibre. In pigs, using a highly viscous non-fermentable soluble polysaccharide, carboxymethylcellulose, showed an increase of the number of ileal goblet cells and luminal crude mucin (Piel et al., 2005). These observations might suggest that soluble fibre viscosity might be a contributing factor in mucin production in the small intestinal.

In rabbits, the inclusion of sugar beet pulp as source of soluble fibre increased the mucin concentration in the ileum and mucin flow to the caecum (El Abed et al., 2011; Abad-Guamán et al., 2015). This effect seems to be more dependent on the soluble fraction of the sugar beet pulp than on the insoluble one (Abad-Guamán et al., 2015). It is due to soluble fraction of sugar beet pulp that enhance the number of goblet cells per villous in the jejunum and the ileal flow of mucin (El Abed et al., 2011). Most of the mucins that reach the caecum are apparently fermented (from 93 to 96\%) (Abad-Guamán et al., 2015).

\subsubsection{Polyunsaturated fatty acid.}

Polyunsaturated fatty acids (PUFAs) are fatty acids containing two or more double bonds. PUFAs are classified into n-6 (omega-6) and n-3 (omega-3) depending of the location of the last double bond relative to the terminal methyl end. They are precursors of the fatty acids linoleic acid (C18:2n-6; LA) and $\alpha$-linolenic acid (C18:3n-3; ALA) and their log chain derivatives (Tanghe et al., 2014) respectively. Both LA and ALA are essential fatty acids since they cannot be synthesized in mammals and must be obtained from the diet (Kurlak and Stephenson, 1999). Mayor sources of n-6 fatty acids are present in vegetable oils such as corn, sunflower, cottonseed, safflower and soybean oil, whereas linseed, canola and fish are sources of n-3 fatty acids (Schmitz and Ecker., 2008; Russo, 2009).

Once absorbed, these fatty acids are metabolized by mammalian cells and they can be converted to longer chain fatty acids through desaturation and elongation by specific enzymes (Sprecher, 2000). The most important long chain derivated fatty acids are arachidonic acid (C20:4n-6; ARA), eicosapentaenoic acid (C20:5n-3; EPA) and docosahexaenoic acid (C22:6n-3; DHA) (Kurlak and Stephenson, 1999). 
Since conversion of n-3 and n- 6 fatty acids share the same series of enzymes, a competition exists between the n-3 and n-6 fatty acids families for metabolism with an excess of one causing a significant decrease in the conversion of the other.

\subsubsection{Reproduction and milk composition.}

Polyunsaturated fatty acids are membrane compounds in the cells of all the tissues, reason by which are essentials for the growth and development of the foetus (Innis, 1991; 2007) and by a correct maturation of numerous organ systems in newborns. They play an important role particularly in retina, brain, neuronal and reproductive tissues (Jensen et al., 1996). Their importance is higher in the second half of pregnancy, coinciding with the period of rapid brain development, and an inadequate supply of n-3 in this period has been associated with impaired visual and cognitive development (Campoy et al., 2012).

Fatty acid requirements (both n-3 and n-6) by the foetus must came from the mother by placental transfer. The transfer mainly occurs in form of long chain fatty acids (Greenberg et al., 2008), because although foetus can synthetize long chain polyunsaturated fatty acids from the essential precursor fatty acids (ALA and LA), the conversion rate is very low (Brenna, 2002; Burdge and Wootton, 2002). Placental fatty acids transfer occurs via passive diffusion, although, long chain fatty acids uptake is also regulated by several transport/binding proteins (Duttaroy, 2009). Moreover, the capacity of adults to convert ALA in EPA and DHA is very limited (Mantzioris et al., 1994; Burdge and Wootton., 2002) although some studies suggest that this capacity increases during lactation (Otto et al., 2001; Bakewell et al., 2006). Accordingly, maternal diet fatty acid composition during pregnancy and lactation can affect the development and growth of both the foetus and the neonate (through the maternal milk) (Gerfault et al., 1999; Lapillonne, 2007). For this reason, it has been realized several studies in sows with different fatty acid supplementation, but not effects on total litter size and number of piglets born were found (Tange and De Smet. 2013). Nevertheless, Corson et al. (2008) showed a lower total and live piglets born in sows fed a sunflower oil diet compared with palm oil during the first middle of the gestation and a positive effect of linseed oil supplementation on sow prolificacy was recently reported (Tanghe et al., 2014).

In rabbits does, the reduction of the a n-6/n-3 fatty acid ratio from 4.1 to 1.0 using extruded linseed oil, but with similar fat level, increased polyunsaturated fatty acids and n-3 fatty acids in milk composition and decreased the n- 6 fatty acids but also tended to 
reduce milk production (Maertens et al., 2005). When n-6/n-3 ratio was decreased from 1.74 to 1.08 using flaxseed or to 0.98 using fish oil, Castellini et al. (2004) observed a similar milk composition in polyunsaturated fatty acids. Moreover, this profile of fatty acids was reflected in suckling rabbit plasma profile. The reduction of $n-6 / n-3$ ratio from 7.3 to 2.2 using salmon oil tended to increase kit weight and survival rate at birth (Rebollar et al., 2014), although the supplementation with marine algae polyunsaturated fatty acids impaired kit weight at birth and at weaning (Mordenti et al., 2010). This situation is similar to that found in sows where n-3 fatty acid supplementation improved piglet viability (Tanghe and De Smet., 2013).

\subsubsection{Intestinal health.}

In immune cells PUFAs, have different functions: i) Fuels for generation of energy. ii) Components of phospholipid bilayer cell membranes, they are responsible of the membrane fluidity. In this sense, Feller et al. (2002) showed that an increase of PUFAs, improved membrane fluidity because their acyl chains are extremely flexible and can change conformational states (Feller et al., 2002). Otherwise, due to some membrane phospholipids are involve in intracellular signaling mechanisms, fatty acids have influence over signal transduction process (Kurlak and Stenphenson, 1999). PUFAs are covalent modifiers of protein structure influencing the cellular location and function of proteins. In this way, oleic acid (C18:1) and ARA can affect the activities of enzymes as phospholipase A2 and proteinase C (Sumida et al., 1993). In addition, they are precursors of synthesis of bioactive lipid mediators like prostaglandins, thromboxane, leukotrienes, lipoxins and resolvins. Long chain PUFA have an effect on immunity through their role in the synthesis of eicosaenoids, wich are chemical messengers synthesizes principally from ARA, but also by dihomo-gamma-linolenic acid (C20: 3n-6; DGLA) and EPA. Eicosanoids obtained from EPA and DHA are principally leukotrienes, lipoxins and resolvins that have an anti-inflammatory role (Schmitz and Ecker, 2008), whereas those came from ARA are leukotrienes and epoxyeicosatrienoic derivate with proinflammatory effects (Bagga et al., 2003; Robinson and stone, 2006) and regulate T and B lymphocyte functions (Calder, 2008). It has been observed that human immune cells contain mainly ARA rather than EPA or DHA, reason why ARA is the predominant precursor for eicosanoid synthesis (Schmitz and Ecker, 2008). It seems that eicosaenoids derived from ARA seems to have more potent biological functions (Calder, 1996). In human, several studies reported that ARA, EPA and DHA contents can also been altered 
through oral intake. Thus, an increase of $\alpha$-linolenic resulted in an increase of EPA content in mononuclear cells (Kelley et al., 1993; Caughey et al., 1996; Kew et al., 2003) and neutrophils (Healy et al., 2000; Mantzioris et al., 1994), but it did not increase DHA content of mononuclear cells or neutrophils. PUFA are also regulators of gene expression either through effects on receptor activity, on intracellular signaling processes, or on transcription factor activation. n-3 PUFAs reduce oxidative stress and NFKB mediated inflammation in immune and intestinal cells (Hassan et al., 2010; Ishida et al., 2010). Thus, in mouse, it has been demonstrated that n-3 PUFAs inhibited the inducible nitric oxide synthase (iNOS) and nitric oxide production of peritoneal macrophages (Aldridge et al., 2008; Meijerink et al., 2011). One possible mechanism by which n-3 PUFAs decrease NFKB signaling is by activation of peroxisome proliferator-activated receptor (PPAR- $\Upsilon$ ) that suppresses inflammatory gene expression interfering with transcriptional activation of NFאB and activator protein-1 (Ricote and Glass, 2007). Omega-3 PUFA also affect cytokine expression. Thus, Wang at al. (2008b) showed that n-3 PUFA supplementation reduced intestinal IL-5 expression in intestinal intraepithelial lymphocytes and Whiting et al. (2005) reported a reduction in lymphocyte-mediated cytokine production, including TNF- $\alpha$, and IL-10.

In rabbits, Maertens et al. (2005) observed that in a experimental farm naturally affected by ERE, rabbits weaned from does fed with a n-3 rich diet and fed with the same diet after weaning $(n-6 / n-3$ ratio $=1.0$, using extruded linseed), reduced their mortality with respect to a control diet. Also, Kelley et al. (1998) observed an enhance immune status in rabbits fed linseed oil that those fed hydrogenated soybean oil, safflower oil or menhaden oil. 
Chapter 2

Evolution of ileal and caecal microbiota, intestinal, immune response and digestive tract in rabbit weaned at 26 d of age 



\subsection{Introduction.}

Weaning is a stressful period for rabbits because of the nutritional transition from milk to solid food and the social events related to housing and litter management. Milk composition contains a diverse group of substances that prevent digestive disturbances during the suckling period (Gallois et al., 2005). In fact, there is usually a positive relationship between weaning age and rabbit viability (Feugier et al., 2006; Romero et al., 2009), although this is not consistent among studies (Garrido et al., 2009).

At the age of weaning (around $35 \mathrm{~d}$ of age), the digestive tract and the immune system of the rabbit are not completely developed (Lebas and Laplace, 1972; Dasso et al., 2000). In this period, the caecum is increasing its size and it is being colonized by a metabolic active commensal microbiota (Padilha et al., 1995; Combes et al., 2011) that interacts with the immune system development (Mage et al., 2006). Weaning (from 21 to $35 \mathrm{~d})$ seems to have little influence on the morphology and enzymatic activity in the upper tract (stomach and small intestine) (Gallois et al., 2005 and 2008). However, other authors found villous atrophy in jejunal mucosa after weaning (Gutiérrez et al., 2002; Campín et al., 2003), which might depend on the weaning diet used (Gómez-Conde et al., 2007). Regarding the hindgut development, a strong effect of the increase of the feed intake after weaning the caecal weight is usually observed (Padilha et al., 1995; Gallois et al., 2005 and 2008) which might be also related to the immune system development. In fact, between 3 and 8 weeks of age gut associated lymphoid tissue (GALT) lymphocytes proliferate and diversify, especially in the appendix, developing the primary antibody repertoire (Knight and Crane, 1994; Mage et al., 2006). Similarly, Carabaño et al. (2008) reported that rabbits weaned at $25 \mathrm{~d}$ showed larger follicular area in the vermiform appendix and higher number of lymphocytes in the lamina propria at $32 \mathrm{~d}$ than suckling rabbits of the same age. Nonetheless, in that study the weaned rabbits had a larger proportion of undifferentiated CD4+/CD8+ T cells. These results confirm that weaning occurs when the immune system is not completely developed, although it might accelerate its maturation. In this process, the intestinal microbiota in the appendix play a crucial role on primary antibody generation and differentiation (Perey and Good, 1968; Stepanková et al. 1980; Hanson and Lanning, 2008). Intestinal microflora also promotes B cell expansion and GALT development (Rhee et al., 2004). Recent studies have shown that GALT development and primary antibody repertoire not only relies on the presence of microorganisms in the gut, but also on the interaction with specific members of the 
normal gut microbiota (Lanning et al., 2000). Thus, Rhee et al. (2004) found that the combination of Bacteroides fragilis and Bacteroides subtilis promoted GALT development and somatic diversification of the primary antibody repertoire. However, weaning seems not to disturb the establishment and metabolic activity of commensal microbiota (Padilha et al, 1995; Combes et al., 2011).

The aim of this study was to determine the evolution of intestinal barrier and microbial colonization in rabbits after weaning and to evaluate the eventual relationship between them.

\subsection{Material and methods.}

\subsubsection{Experimental procedure.}

This study was approved by the Committee of Ethics of the Departamento de Producción Animal of the Universidad Politécnica de Madrid. All animals were handled according to the principles of animal care published by Spanish Royal Decree 53/2013 (BOE, 2013).

One hundred and thirteen crossbred (New Zealand White $\times$ Californian) rabbits from 20 litters (9-10 rabbits/litter), from a farm regularly affected by epizootic rabbit enteropathy outbreaks, were weaned at $26 \mathrm{~d}$ of age with an average weight of $429 \pm 57 \mathrm{~g}$. Rabbits were housed individually in flat-deck cages measuring $610 \times 250 \times 330 \mathrm{~mm}$. A cycle of 12 hours of light and 12 hours of dark was used throughout the experiment. Heating and forced ventilation systems maintained the building temperature between 18 and $24{ }^{\circ} \mathrm{C}$. Rabbits had ad libitum access to water and to a commercial feed (Nanta, S.A.) free of antibiotics that was also supplied to their mothers. It contained $12 \%$ moisture, $15.8 \% \mathrm{CP}, 43.5 \%$ total dietary fibre (TDF), 35.9\% NDF, 16.7\% ADF, 3.3\% ADL and $7.6 \%$ soluble fibre (measured as TDF-NDF). The estimated digestible energy was 10.1 MJ/kg (De Blas et al., 1992). From 26 to $52 \mathrm{~d}$ feed intake and live weight was recorded. At 26, 31, 38, 45 and $52 \mathrm{~d}$ of age, one healthy rabbit per litter was slaughtered between 1000 and $1300 \mathrm{~h}$ by $\mathrm{CO}_{2}$ inhalation (20 rabbits/age). Thirteen rabbits (11.5\%) presented symptoms of epizootic rabbit enteropathy (ERE) and were discarded.

\subsubsection{Determination of mucosa morphology.}

Segments of $3 \mathrm{~cm}$ length were taken from the middle part of the jejunum of 100 rabbits (20 animals/age), cleaned with saline solution ( $\mathrm{NaCl} 0.9 \%)$, opened longitudinally 
and collected into $10 \%$ neutral buffered formaldehyde solution (pH 7.2 to 7.4) and stored for histological analysis. Only 89 samples were used, because 11 samples resulted damaged during processing. The samples used were gradually dehydrated in an ethanol series (50 to $100 \%$ ) and infiltrated with paraffin wax using tissue processor LEICA ASP 300 and then were sectioned at $5 \mu \mathrm{m}$ with microtome LEICA RM 2255. One slide was prepared from each sample. The slides were processed for carbohydrate histochemistry using dyes. The dye method was Alcian blue reaction at $\mathrm{pH} 2.5$, which stains carboxylated or sulfated types of acidic mucins (Kiernan, 1999), using an automatic procedure (ArtisanTM Link Special Staining System). The sections were placed in acetic acid$\mathrm{AB} 2.5$, pH 2.5 for $5 \mathrm{~min}$, afterwards in alcian blue-AB 2.5, $\mathrm{pH} 2.5$ for $10 \mathrm{~min}$, at $37^{\circ} \mathrm{C}$ and subsequently washed in water six times. The sections were counterstained with eosin, dehydrated, and covered with a cover slip using nuclear fast red-AB2.5 for $10 \mathrm{~min}$ and subsequently washed in water six times, according to the procedure described by Brunsgaard (1997). One slide containing jejunal section was prepared for each sample and all of them were viewed at 40x magnification using an Olympus BX-40 light microscope. Images were digitally captured for later analysis using Soft software version 3.2 C4040Z (Soft Imaging System, Olympus, GmbH, Hamburg, Germany), and analyzed eye blinded by the same person. Villous height and crypt depth were determined according to the procedure described by Hampson (1986) and an average of the measurements was obtained for each animal. The amount of mucin granulates of goblet cells from each villi measured were counted.

\subsubsection{Characterization of immune response.}

Twenty five animals (5 rabbits/age) were used from six litters. Segments of $3 \mathrm{~cm}$ of ileum next to the ileo-caecal valve to the first Peyer's patch, and $2 \mathrm{~cm}$ of the last section of the appendix were taken. Samples were cleaned with saline solution $(\mathrm{NaCl} 0.9 \%)$, cut longitudinally and scraped to obtain approximately $50 \mathrm{mg}$ of mucosa. Finally, samples were placed in vials containing $1 \mathrm{ml}$ of RNA preserving solution (RNA Later, Ambion) and frozen at $-80^{\circ} \mathrm{C}$. Tissue disruption for RNA isolation from ileal mucosal scrapings and appendix was performed using Trizol reagent (Sigma-Aldrich, St Louise, MO, USA) and a mixer mill MM-200 (Restch, Stuttgart, Germany). Total RNA was isolated using the GenElute Mammalian Total RNA Miniprep kit (Sigma-Aldrich, St Louise, MO, USA) according to manufacturer's instructions. A DNAse treatment step using RNase-Free DNase Set (Qiagen, Hilden, Germany) was added to prevent genomic DNA 
contamination. The RNA concentration was measured by spectrophotometry $\left(\right.$ Epoch $^{\mathrm{TM}}$, BioTek, Winoosky, VT, USA) combined with the Take $3^{\text {TM }}$ Micro-Volume Plate (BioTek, Santa Barbara, CA, USA). The extracted A260/ A280 ratio was used to calculate the quantity of diluted RNA for the following reverse transcription.

First strand cDNA was synthesized using the High-Capacity cDNA Archive Kit (Applied Biosystems Foster City, CA, USA) according to the manufacturer's instructions. The relative gene expression of selected cytokines was determined using real-time, quantitative PCR. The specific primers for rabbit glyceraldehyde-3 phosphate (GADPH) (housekeeping), IL-2, IL-10, interferon-gamma (IFN- $\gamma$ ) and tumor necrosis factor-alpha (TNF- $\alpha$ ) were taken from Godornes et al. (2007) and Chamorro el al. (2010). Those for IL-6, IL-8 and the inductible nitric oxide synthase (iNOS) were designed by us using Primer Express ${ }^{\circledR}$ v.2 (Applied Biosystems, Foster City, CA, USA) (Table 1). The specificity of the amplified products was confirmed though the melting curve analysis and further confirmed by gel electrophoresis. The quantitative PCR was performed in an ABI Prism 7300 Sequence Detector System (Applied Biosystems, Foster City, CA, USA). Each reaction mix consisted on around $100 \mathrm{ng}$ of first strand cDNA as a template, specific primers, ultrapure water and SYBR® Green Master Mix (Applied Biosystems Foster City, CA, USA) as fluorescent DNA intercalating agent. All samples were run in triplicate and quantified by normalizing the target gene signal to that of the GADPH.

\subsubsection{Characterization of intestinal microbiota.}

For microbial analysis, $1 \mathrm{~g}$ of caecal, soft faeces (obtained from the rectum) and ileal digesta were collected simultaneously from three rabbits of each age in sterile plastic tubes containing $3 \mathrm{ml}$ of $98 \%$ molecular biology grade ethanol. Caecal digesta and soft faeces were mixed in a ratio 50:50. The collected samples were maintained at $4{ }^{\circ} \mathrm{C}$ until use. Microbiota biodiversity were determined by $16 \mathrm{~S}$ rRNA RFLP according to the following procedure: $400 \mathrm{mg}$ of each simple collected were processed for total DNA extraction using the QIAamp DNA Stool Mini Kit system (Qiagen Inc., Chatsworth, California), following the manufacturer's instructions, with additional lysozyme and proteinase K steps. The purified DNA was maintained at $-20^{\circ} \mathrm{C}$ until use. The primers 5'-CTACGGGAGGCAGCAGT-3' and 5'-CGTCWATTCMTTTGAGTTT- 3', corresponding to regions I and II of the 16S rRNA gen (Lane, 1991), were used to amplify a 500 to 600 bp product. Amplifications were performed in a final volume of $50 \mu \mathrm{L}$ using 
a PCR-Master Mix (Applied Biosystems) containing 1.25 UI of Taq polymerase, $50 \mathrm{ng}$ of DNA, $0.2 \mu \mathrm{M}$ of each primer, and the following cycling conditions: $94{ }^{\circ} \mathrm{C}$ for $5 \mathrm{~min}$, following by 35 cycles of $94{ }^{\circ} \mathrm{C}$ for $1 \mathrm{~min}, 45^{\circ} \mathrm{C}$ for $1 \mathrm{~min}$ and $72{ }^{\circ} \mathrm{C}$ for $1 \mathrm{~m} 15 \mathrm{~s}$. The last extension cycle was continued for $5 \mathrm{~min}$. Amplified products were cloned at random and sequenced to analyze the homology of the sequences obtained with those stores in the GenBank sequence database of the National Center for Biotechnology Information (NCBI) to obtain the operational taxonomic units (OTUs).

\subsubsection{Analytical methods.}

Procedures of the AOAC (2000) were used to determine the dietary concentrations of DM (934.01), ash (942.05), nitrogen (954.01), ether extract (920.39), starch (amyloglucosidase- $\alpha$-amylase method; method 996.11) and total dietary fibre (985.29). Dietary aNDFom, ADFom and lignin (sa) were determined sequentially using the filter bag system (Ankom Technology, New York, NY). Dietary aNDFom was determined according to Mertens et al. (2002) using a thermo-stable amylase without any sodium sulphite added. Dietary ADFom and ADL were analyzed according to Goering and Van Soest (1970). The soluble fiber was calculated as the difference between total dietary fibre and aNDFom (both corrected for ash and protein). Gross energy was measured by adiabatic bomb calorimeter (model 356, Parr Instrument Company, Moline, IL).

\subsection{6. $\quad$ Statistical methods.}

Data of growth performance, weight of intestinal tract and caecum and the measurements of mucosal morphology were analyzed as a completely randomized design with age and litter as the main sources of variation by using the GLM procedure of SAS (SAS Inst., Cary, NC). Means were compared using a protected t-test, and the differences were considered significant at $\mathrm{P}<0.05$. The analysis of gene expression consisted of the mixed-model to test age related linear and quadratic effects. Also, differences in gene expression resulting from the comparison of rabbits at 31, 38, 45 and $52 \mathrm{~d}$ of age relative to the control group (26 d) were determined using a mixed-model in which age was included as fixed effect and the sample as random (Steibel et al., 2009). For genes displaying efficiencies different from $2(\mathrm{E} \neq 2), \mathrm{Ct}$ values were adjusted according to the model described by Steibel et al. (2009). The standard error (SE) was used to recalculate the lower and upper $95 \%$ confidence intervals for each fold change. 
For rRFLP microbiota data, statistical analysis were carried out using STATFINGERPRINTS version 1.3 (Michelland et al., 2009) running on R version 2.10 (R Development Core Team, 2010). The similarity of the profile of the bands obtained by tRFLP for each treatment group was measured using the Bray Curtis distance. Bacterial community distance matrices were explored using non metric multidimensional scaling (nMDS). Stress values lower than 20 indicated that the observed plot is a reliable representation of the data (Corrigan et al., 2011). Between-group differences in ileal and caecal bacterial community, tRFLP profile were statistically tested with analyses of similarity (R-ANOSIM). R-ANOSIM tests the significance of clusters with a P-value based on 10000 Monte Carlo permutations, and calculates the degree of difference between groups with $\mathrm{R}$ statistic from 0 (poorly different) to 1 (well separated) (Ramette, 2007). Difference were considered significant when $P<0.05$, and close to significance when $0.05<\mathrm{P}<0.10$. The number of operational transfer units (OTU) in the intestinal microbiota was analyzed using logistic regression (GENMOD procedure of SAS, considering a binomial distribution) using non-orthogonal contrasts to compare the different age groups, and results transformed from the logit scale (P-values indicated in the figures). Also, linear and quadratic effects were tested (P-values indicated in the text).

\subsection{Results.}

Feed intake and growth rate increased with age (Table 2. P $<0.001$ ). The relative weight of the digestive tract increased up to $38 \mathrm{~d}$ of age (by 37\%) and then decreased and stabilized from $45 \mathrm{~d}$ onwards $(\mathrm{P}<0.05$. Table 3 ). From 26 to $38 \mathrm{~d}$ of age the relative weight of the caecum also increased (by 66\%), and tended to decrease and stabilized at 45 and $52 \mathrm{~d}$ of age. The villous height and the number of goblet cells per villi decreased in rabbits of $31 \mathrm{~d}$ of age compared to still suckling rabbits of $26 \mathrm{~d}$ (by $26 \%$ and $23 \%$ respectively. $\mathrm{P}<0.05$ ), while no effect was observed in the crypth depth (Table 3 ). At 38 $\mathrm{d}$ of age villous height and the number of goblet cells recovered their values and crypt depth increased $(\mathrm{P}<0.05)$. From 38 to $52 \mathrm{~d}$ of age crypth depth and the number of goblet cells increased by 9 and 32\% ( $<<0.05)$ with no change on the villous height. When the value of the number of goblet cells per villi was corrected for the villous height it remained constant from 26 to $45 \mathrm{~d}$ of age (17.2 on average) increasing at $52 \mathrm{~d}$ up to 21.7 $(\mathrm{P}<0.05)$. 
The ileal RFLP profiles evolved with age (R-ANOSIM $=0.241, \mathrm{P}<0.001$; Figure 1A). However, ileal RFLP profiles of all age groups were strongly overlapped (Figure 1A). Rabbits between 26 and 38 d of age showed separated ileal RFLP profiles (RANOSIM $\geq 0.188$. $\mathrm{P}<0.05$. Table 4). However, rabbits from 38 day-old group and older rabbits (45 and 52 day-old) showed no difference in their ileal RFLP profiles (RANOSIM $\leq 0.142, \mathrm{P}>0.05$; Table 4). The OTUs found in the ileum came for four different phylum: Firmicutes, Bacteroidetes, Proteobacteria and Verrumicrobia (Figure 2A). A quadratic effect was found for the evolution of the proportion of Firmicutes $(\mathrm{P}=$ 0.002; maximal value at $38 \mathrm{~d}$ of age). Bacteroidetes showed also a quadratic evolution opposite to that of Firmicutes with a minimal value between 38 and $45 \mathrm{~d}(\mathrm{P}=0.003)$. Proteobacteria and Verrumicrobia did not show a significant evolution with age. The quadratic evolution of the ileal proportion of Firmicutes was due to a positive quadratic $(\mathrm{P}<0.001)$ evolution of an unidentified OTUs belonging to the Clostridiales order (with a maximal value at $38 \mathrm{~d}$ of age; Figure $2 \mathrm{~B}$ ), as Lachnospiraceae family decreased with age $(\mathrm{P}=0.021)$. No clear evolution was found for Ruminococcaceae family, unidentified Lactobacillales order and unidentified Firmicutes. The quadratic effect observed for Bacteroidetes is due to the increase of Porphyromonadaceae family at $52 \mathrm{~d}$ of age as no change was observed for Bacteroidaceae and Rikenallaceae families (Figure 2C).

The caecal RFLP profiles also evolved with age although in a different way than in the ileum $(\mathrm{R}-\mathrm{ANOSIM}=0.902, \mathrm{P}<0.001$; Figure 1B). The evolution was much better defined than in the ileum and rabbits of all different age-groups showed a separated caecal RFLP profiles (R-ANOSIM $\geq 0.737$. $\mathrm{P}<0.001$. Table 4). Only caecal RFLP profiles from 31 day-old rabbits were partially overlapped with those of 26 and $38 \mathrm{~d}$ of age (Figure 1B), showing a progressive separation between 38 and $26 \mathrm{~d}$ of age. Besides, 38 day-old rabbits were the most distanced with 45 and 52-d old rabbits-groups (R-ANOSIM = 1, P < 0.001; Table 4). Groups of 45 and $52 \mathrm{~d}$ of age were also well separated but the difference was lower than that of the younger groups (Table 4. Figure 1B). All these age-related changes observed in the caecal RFLP profiles were also found in the evolution of OTUs composition. The OTUs detected in the caecal digesta came from three phylum: Firmicutes, Verrumicrobia and Bacteroidetes (Figure 3A). At weaning Firmicutes and Bacteroidetes represented each one around half of the caecal OTUs detected. The proportion of Firmicutes increased from 31 to $38 \mathrm{~d}$ of age, substituting the phylum Bacteroidetes that decreased in this period $(\mathrm{P}<0.05)$, leading to a positive or negative 
linear effect of age, respectively, on these phylum. In fact, from $38 \mathrm{~d}$ of age onwards Firmicutes was the dominant phylum accounting for more than $80 \%$ OTUs detected. There was no trend for the evolution of the proportion of Verrumicrobia with age. The increase in the caecal proportion of Firmicutes was due to a positive linear and quadratic $(\mathrm{P}<0.001)$ evolution of an unidentified OTUs belonging to the Clostridiales order (with a maximal value at $45 \mathrm{~d}$ of age) and a linear increase of an unidentified OTUs from the Firmicutes phylum $(\mathrm{P}=0.020$. Figure $3 \mathrm{~B})$. No clear evolution with age was found for the Ruminococcaceae and Lachnospiraceae families. The decrease in the caecal proportion of the Bacteroidetes phylum was accounted for the linear decrease with age of the Bacteroidaceae family $(\mathrm{P}<0.001)$ and unidentified Bacteroidales order $(\mathrm{P}=0.010$. Figure 3C). The families Porhyromonadaeae and Rikenallaceae did not show a significant evolution with age.

The relative gene expression of all studied cytokines (Figure 4) were lower ( $\mathrm{P}<$ 0.05) in the ileum than in the appendix, except for IFN- $\gamma$ that showed an opposite trend. This effect was observed at all ages except at $31 \mathrm{~d}$, where the relative gene expression of TNF- $\alpha$, iNOS and IL8 in the ileum were not different $(P>0.10)$ of that in appendix. The relative gene expression of TNF- $\alpha$ in the appendix (Figure 5A) was upregulated at 26 and $31 \mathrm{~d}$ of age $(\mathrm{P}<0.05)$. In the ileum (Figure 5B), a quadratic evolution of TNF- $\alpha$ relative gene expression with age was observed $(\mathrm{P}=0.03)$, peaking at $31 \mathrm{~d}$ of age. On the opposite, IFN- $\gamma$ in the appendix (Figure 5C) and ileum (Figure 5D), and IL-2 in the ileum (Figure $5 F)$ increased linearly with age $(\mathrm{P} \leq 0.01)$. The relative gene expression of the other cytokines studied in the present study (IL-6, IL-8, IL-10) and iNOS did not show a significant evolution with age. However, it was noticeable the down-regulation of IL8 (1 vs. 0.19 fold change; $P=0.02$ ) and the trend of IL6 ( 1 vs. 0.26 fold change; $P=0.071$ ) and IL2 ( 1 vs. 0.36 fold change; $\mathrm{P}=0.11$ ) to decrease its expression in the appendix of rabbits at $31 \mathrm{~d}$ of age compared to those at $26 \mathrm{~d}$. Also, an increased expression of iNOS ( 1 vs. 4.08 fold change; $P=0.020$ ) in the appendix was observed in rabbits at $38 \mathrm{~d}$ of age compared to those at $26 \mathrm{~d}$.

\subsection{Discussion.}

In the present study is reported the inverse relationship between the Bacteroidetes and Firmicutes phylum in the ileum and caecum after weaning. A partial and gradual substitution of Bacteroidetes for Firmicutes phylum was found in the caecum along the 
two weeks after weaning (25-38 d of age), coinciding with the relevant increase of feed intake and caecal relative weight occurring in this period. This result contrasts with the minor reduction of the Bacteroides-Prevotella group and the constant Firmicutes concentration in the caecum after weaning reported by Combes et al. (2011).

Simultaneously, at $31 \mathrm{~d}$ of age it was observed an upregulation of the TNF- $\alpha$ relative gene expression in the appendix and ileum, similar to that found in the intestinal mucosa of piglets just after weaning (Pie et al., 2004; Hu et al., 2013). This cytokine was upregulated longer in the appendix than in the ileum, section that contains a higher microbial concentration, and might be the result of a direct immune stimulation by the microbiota or its derived products. However, other proinflammatory cytokines (IL-8, IL6 and IL-2) were or tended to be downregulated in in the rabbit appendix, but not in the ileum, at $31 \mathrm{~d}$ of age differing to that observed by these authors in pigs. This regulation might counterbalance the negative effect of proinflammatory cytokines on gut integrity (Bruewer et al., 2003). Nevertheless, it was observed at $31 \mathrm{~d}$ of age an important reduction of the villous length in the jejunum, which might be related to the transient and quantitatively high TNF- $\alpha$ upregulation in the ileum. Part of this effect, might be explained by the negative effect of TNF- $\alpha$ on sugar uptake by the intestinal mucosa, as observed after the intravenous administration of TNF- $\alpha$ to rabbits (García-Barrios et al., 2013). This reduction of the villous height after weaning was also observed when using a low soluble fibre diet (Gómez-Conde et al., 2007), similar to the one of this experiment, but it was not found when using diets with higher soluble fibre level (Gallois et al., 2005; Gómez-Conde et al., 2007). In contrast, in the current work a parallel reduction of crypt depth was observed, and might suggest a delay in the repair mechanism. Nonetheless, both villous height and crypt depth increased at $38 \mathrm{~d}$ of age, indicating that it was a transient damage.

From $38 \mathrm{~d}$ of age onwards, the ileal microbiota seemed more stable according to the ileal RFLP-profiles, although Bacteroidetes and Firmicutes phylum recover the balance they had just after weaning. In contrast, in the caecum the caecal RFLP-profiles indicated a clear differentiation of microbiota with ageing, although the relative importance of both phylum remained constant and dominated by the Firmicutes phylum (84.4\% of total OTUs) compared to Bacteroidetes $(11.5 \%)$ or Verrumicrobia $(4.1 \%)$. These proportions are similar to those found in healthy $40 \mathrm{~d}$ old rabbits: 78.2 Firmicutes, 15.7\% Bacteroidetes and 2.4\% Verrumicrobia. (Bäuerl et al., 2014), and agree also with 
the greater importance of Firmicutes phylum (94\%) compared to Bacteroidetes (4\%) found in adult rabbits (Monteils et al., 2008). In this period, it is also observed a parallel increase of the relative gene expression of IFN- $\gamma$ in the appendix and ileum and IL-2 in the ileum. These cytokines are usually related to a Th1-mediated immune response adapted to fight against intracellular pathogens (Mowat, 2003). They promote macrophage phagocytosis, natural killer cell activation and CD8+ cytotoxic $\mathrm{T}$ lypmphocytes killing (Williams, 2012). Besides, this innate immune response might regulate the differenciation of goblet cells, and especifically IFN- $\gamma$ affect goblet cells by increasing mucin production (McGuckin et al. 2011). Accordingly, the greater increase of IFN- $\gamma$ gene expression at $52 \mathrm{~d}$ of age might be related to the sharp increase of globet cells at this age.

The cytokine profile obtained in the current study did not match with that reported in rabbits affected by ERE: increase of IL-6, IL-8, IL-10, iNOS and TNF- $\alpha$ gene expression in the ileal mucosa (Menoyo et al., 2010) or increase of IL-6, IL-8 and TNF$\alpha$ gene expression in the caecal mucosa (Bäuerl et al., 2014). These results of both the microbiota and cytokine profile confirms that the rabbits used in the current experiment were not affected by ERE. However, the values recorded for both growth rate and feed intake from 26 to $30 \mathrm{~d}$ were $17 \%$ and a $33 \%$ worse than the values that would correspond according to the age and genetic type (Gutiérrez et al., 2003). In this period, animals were eating on average $944 \mathrm{~kJ} / \mathrm{d}$ and $\mathrm{kg}$ BW0.75, a value that is above of the maintenance requirements (Parigi-Bini and Xiccato, 1998), but is around 22\% lower than the required energy to achieve the normal growth rate (Gutiérrez et al., 2003). Decreased feed intake was also observed by Gallois el al. (2005) in weaned animals at 21 and $35 \mathrm{~d}$ of age. Even though feed intake increased with age, live weight at $52 \mathrm{~d}$ reduced by $20 \%$ respect to the expected value. These results could be due to the poor adaptation of kits to the feed after weaning or because animals had a subclinical disease that led to a lower feed intake. In these conditions, a relevant part of the nutrients might be used by the immune system reducing the growth rate. This hypothesis would agree with the reduction of feed efficiency found from 26 to $31 \mathrm{~d}$ and 38 to $44 \mathrm{~d}$ of age. These are the periods where the immune system may reacts either to the entrance of new antigens in the digestive tract (from 26 to $31 \mathrm{~d}$ ), when the caecum showed a major enlargement, or to the development of the Epizootic Rabbit Enteropathy (from 37 to 44 d of age. Pérez de Rozas et al., 2005). 
Chapter 2: Evolution of ileal and caecal microbiota, intestinal immune response and digestive tract in rabbits weaned at 26 days of age.

In conclusion, after weaning there is a specific balance between Firmicutes and Bacteroidetes in the ileum and caecum and some temporary changes in the mucosa morphology and immune response that must be taken into consideration when evaluating new management/dietary strategies. 
Table 1. Sequences for primers (forward and reverse) for real-time reverse-transcription PCR amplification of target genes.

\begin{tabular}{llll}
\hline \multicolumn{1}{c}{ Gene $^{1}$} & \multicolumn{1}{c}{ GenBank } & \multicolumn{1}{c}{ Forward } & \multicolumn{1}{c}{ Reverse } \\
\hline GADPH $^{3}$ & AB231852 & 5'-GGGCGTGAACCACGAGAA- 3' & 5'-GCCGAAGTGGTCGTGGAT-3' \\
${\text { TNF- }{ }^{2}}^{\prime}$ & M12845 & 5'-GTCTTCCTCTCTCACGCACC-3' & 5'-TGGGCTAGAGGCTTGTCACT-3' \\
IL-10 $^{2}$ & D84217 & 5'-GAGAACCACAGTCCAGCCAT-3' & 5'-CATGGCTTTGTAGACGCCTT-3' \\
IL-6 & DQ680161 & 5'-GAGCATCCTGGAGACCATCAA-3' & 5'-CCAGTGCCTCCTTTCTGTTCA-3' \\
IL-8 & Ensembl $^{4}$ & 5'-GCAACCTTCCTGCTCTCTCTGA-3' & 5'-CACTGGCATCGAAGCTCTGTAC-3' \\
IL-2 & Ensembl $^{5}$ & 5'-TGAAACATCTTCAGTGTCTAGAAG -3' & 5'-CCATTTGTTCAGAAATTCTACAATG -3' \\
iNOS & NM_000625 & 5'-GCCATCGAGTTTGTCAACCA-3' & 5'-TCCTTTGTGACCGCTTCCA-3' \\
IFN- $\gamma$ & NM_001081991.1 & 5'-TTCTTCAGCCTCACTCTCTCC -3' & 5'-TGTTGTCACTCTCCTCTTTCC -3' \\
\hline
\end{tabular}

${ }^{1}$ Target genes: glyceraldehyde-3 phosphate = GAPDH; tumor necrosis factor-alpha = TNF- $\alpha$; IL-2; IL-6; IL-8; IL-10; inducible nitric oxide synthase $=$ iNOS; interferon gamma $=$ IFN- $\gamma$.

${ }^{2}$ Godornes et al. 2007.

${ }^{3}$ Chamorro et al. 2010.

${ }^{4}$ Rabbit Ensembl ENSOCUG00000011835.

${ }^{5}$ Rabbit Ensembl ENSOCUG00000010100. 
Table 2. Effect of age on growth performance of rabbits weaned at $26 \mathrm{~d}$ of age

\begin{tabular}{|c|c|c|c|c|c|c|}
\hline & \multicolumn{4}{|c|}{ Age, $d$} & \multirow[t]{3}{*}{ rsd } & \multirow[t]{2}{*}{ P-value } \\
\hline & $26-30$ & $30-37$ & $37-44$ & $44-51$ & & \\
\hline $\mathrm{N}$ & 80 & 60 & 40 & 20 & & \\
\hline Average daily gain, g/d & $26.0^{\mathrm{a}}$ & $33.8^{\mathrm{b}}$ & $42.4^{\mathrm{c}}$ & $42.1^{\mathrm{c}}$ & 7.07 & $<0.001$ \\
\hline Average daily feed intake, $\mathrm{g} / \mathrm{d}$ & $52.7^{\mathrm{a}}$ & $62.3^{\mathrm{b}}$ & $88.6^{\mathrm{c}}$ & $101.5^{\mathrm{d}}$ & 12.6 & $<0.001$ \\
\hline Feed efficiency, g gain/g feed intake & $0.503^{\mathrm{bc}}$ & $0.548^{\mathrm{c}}$ & $0.472^{\mathrm{ab}}$ & $0.416^{\mathrm{a}}$ & 0.12 & $<0.001$ \\
\hline
\end{tabular}


Table 3. Effect of age on the weight of the digestive tract, caecum and jejunal mucosa morphology in young rabbits weaned at $26 \mathrm{~d}$ of age.

\begin{tabular}{|c|c|c|c|c|c|c|c|}
\hline & \multicolumn{5}{|c|}{ Age, $d$} & \multirow[t]{2}{*}{ rsd } & \multirow[t]{2}{*}{ P-value } \\
\hline & 26 & 31 & 38 & 45 & 52 & & \\
\hline Body weight (BW), g & $\overline{425^{\mathrm{a}}}$ & $\overline{506^{\mathrm{b}}}$ & $\overline{755^{\mathrm{c}}}$ & $\overline{1148^{d}}$ & $\overline{1374^{\mathrm{e}}}$ & 95.3 & $<0.001$ \\
\hline Weight of digestive tract, $\% \mathrm{BW}$ & $20.5^{\mathrm{c}}$ & $23.4^{b}$ & $28.1^{\mathrm{a}}$ & $25.0^{\mathrm{b}}$ & $24.8^{\mathrm{b}}$ & 3.21 & $<0.001$ \\
\hline Weight of caecum, \% BW & $4.90^{\mathrm{b}}$ & $7.14^{\mathrm{c}}$ & $8.12^{\mathrm{a}}$ & $7.44^{\mathrm{ac}}$ & $7.30^{\mathrm{ac}}$ & 1.23 & $<0.001$ \\
\hline \multicolumn{8}{|l|}{ Jejunal mucosa morphology } \\
\hline Villous height, $\mu \mathrm{m}$ & $605^{\mathrm{a}}$ & $450^{\mathrm{b}}$ & $567^{\mathrm{a}}$ & $600^{\mathrm{a}}$ & $606^{\mathrm{a}}$ & 105 & $<0.001$ \\
\hline Crypt depth, $\mu \mathrm{m}$ & $81.0^{\mathrm{c}}$ & $78.5^{\mathrm{c}}$ & $94.6^{\mathrm{b}}$ & $100^{\mathrm{ab}}$ & $103^{\mathrm{a}}$ & 8.63 & $<0.001$ \\
\hline No. goblet cells/villi & $18.5^{\mathrm{b}}$ & $14.3^{\mathrm{c}}$ & $17.4^{\mathrm{b}}$ & $18.5^{\mathrm{b}}$ & $22.9^{\mathrm{a}}$ & 3.41 & $<0.001$ \\
\hline
\end{tabular}

${ }^{\mathrm{a}-\mathrm{c}}$ Mean values in the same row with a different $\mathrm{P}<0.05(\mathrm{n}=20$ rabbits/age, and $\mathrm{n}=16$ rabbits/age for jejunal mucosa morphology). 

digestive tract in rabbits weaned at 26 days of age.

Table 4: RFLP similarity value (R-ANOSIM) between the different age groups for ileal and caecal microbiota ( $\mathrm{n}=8$ profiles per age group and segment)

\begin{tabular}{rcccc}
\hline \multicolumn{1}{c}{$26 \mathrm{~d}$} & $31 \mathrm{ds}$ & $38 \mathrm{~d}$ & $45 \mathrm{~d}$ \\
\hline $31 \mathrm{~d}$ & $0.461^{* * *}$ & & & \\
$38 \mathrm{~d}$ & $0.396^{* * *}$ & $0.188^{* * *}$ & & \\
$45 \mathrm{~d}$ & $0.577^{* * *}$ & $0.284^{* * *}$ & $0.142^{* * *}$ & \\
$52 \mathrm{~d}$ & $0.329 * * *$ & $0.164^{* * *}$ & $0.007 * *$ & $0.056^{* *}$ \\
Caecum & & & & \\
$31 \mathrm{~d}$ & $0.831^{* * *}$ & & & \\
$38 \mathrm{~d}$ & $0.958^{* * *}$ & $0.737 * * *$ & & \\
$45 \mathrm{~d}$ & $0.926 * * *$ & $0.909 * * *$ & $1 * * *$ & \\
$52 \mathrm{~d}$ & $0.964 * * *$ & $0.969 * * *$ & $1 * * *$ & $0.938^{* * *}$ \\
\hline
\end{tabular}

$* \mathrm{P}<0.05 . * * \mathrm{P}<0.01$. *** $\mathrm{P}<0.001$. 


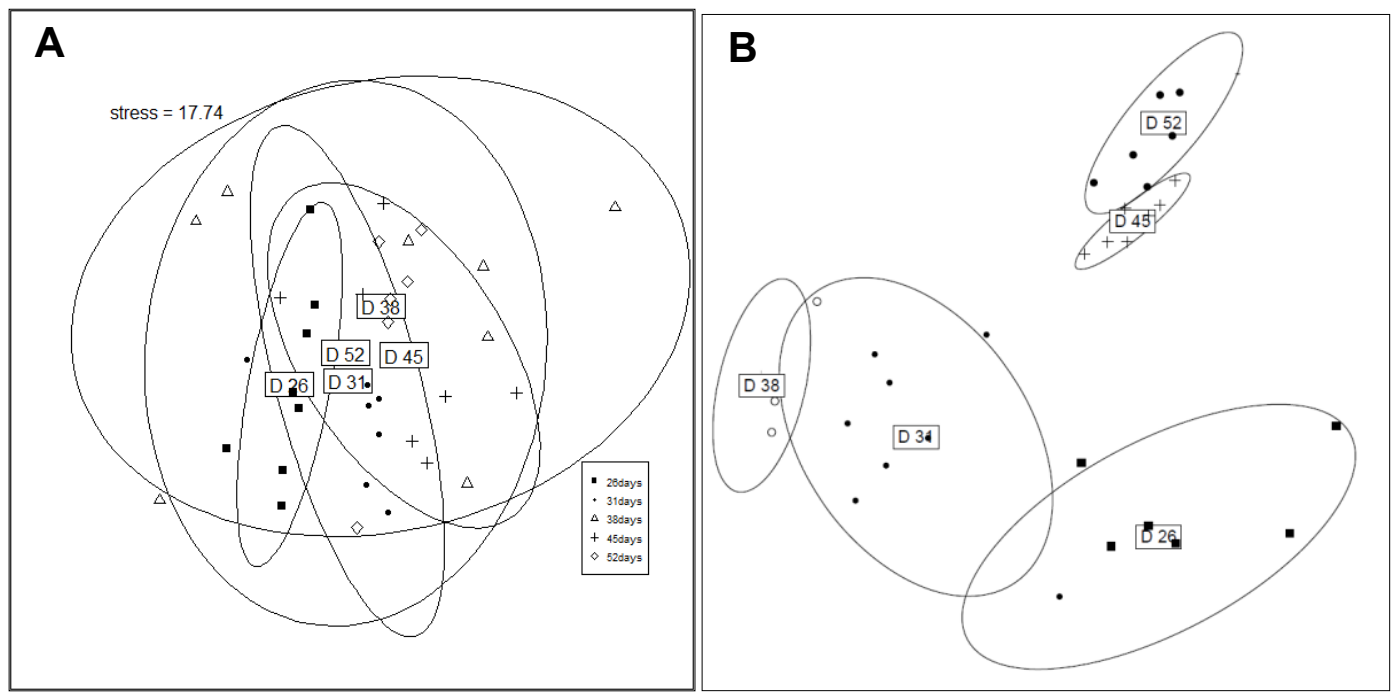

Figure 1: nMDS plot of RFLP profiles of rabbit ileal (A) and caecal (B) bacterial community at $26(\bullet), 31(\bullet), 38(\circ), 45(+)$ and $52(\Delta)$ d of age. Ileum: stress = 17.7, R-ANOSIM = 0.24, $\mathrm{P}<0.001$. Caecum: stress $=10.98, \mathrm{R}-\mathrm{ANOSIM}=0.902, \mathrm{P}<0.001 . \mathrm{n}=8$ profiles per age group and se 

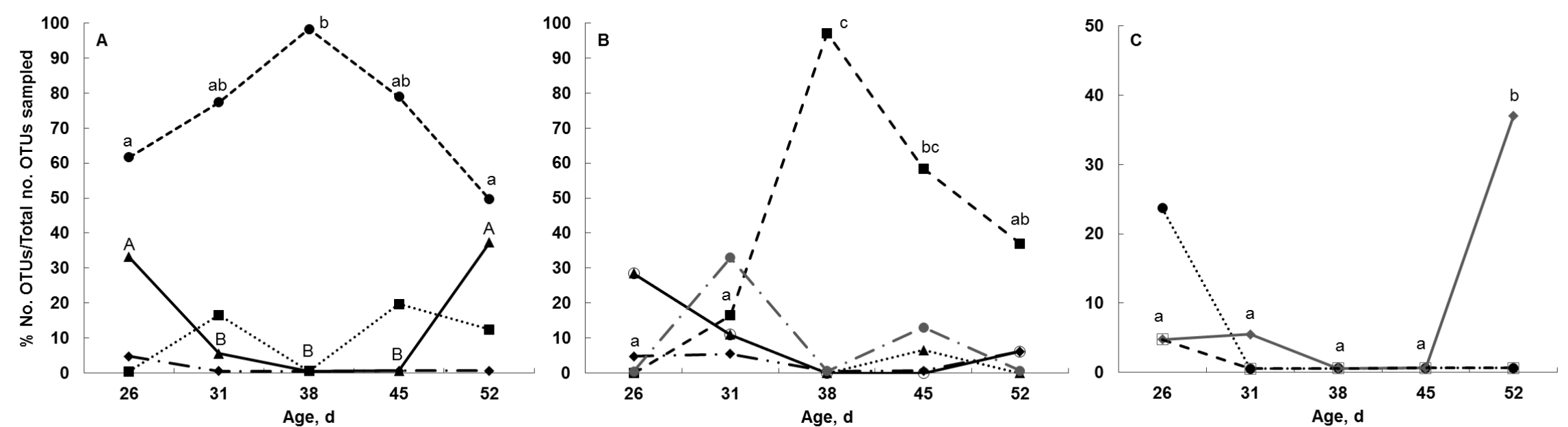

Figure 2. Evolution of ileal microbiota after weaning (26 d) measured as operational taxonomic units (OTUs). A. Phylum: $\mathbf{\Delta}$ Bacteroidetes, $\mathrm{P}_{\mathrm{age}}<0.001$. Firmicutes, $\mathrm{P}_{\mathrm{age}}=0.007$. Proteobacteria, $\mathrm{P}_{\mathrm{age}}=0.073 \bullet$ Verrumicrobia, $\mathrm{P}_{\mathrm{age}}=0.83$. Lower case and capital letters indicate differences for Firmicutes and Bacteroidetes proportions, respectively, with age. B. Families from Firmicutes phylum: $\mathbf{\Delta}$ Lachnospiraceae, $\mathrm{P}_{\mathrm{age}}=0.064 . \circ$ Ruminococcaceae, $\mathrm{P}_{\mathrm{age}}=0.058$. Unidentified Clostridiales, $\mathrm{P}_{\mathrm{age}}<0.001 . \diamond$ Unidentified Firmicutes, $\mathrm{P}=0.78 . \bullet$ Unidentified Lactobacillales, $\mathrm{P}_{\mathrm{age}}=0.062$ Lower case letters indicate differences for unidentified Clostridiales proportion with age. C. Families from Bacteroidetes phylum: $\bullet$ Bacteroidaceae, $\mathrm{P}_{\mathrm{age}}=0.065$. Porphyromonadaceae, $\mathrm{P}_{\mathrm{age}}=0.005 . \square$ Rikenallaceae, $\mathrm{P}_{\text {age }}=0.53$. Lower case letters indicate differences for Porphyromonadaceae proportion with age. Number of total OTUs at 26, 31, 38, 45 and $52 \mathrm{~d}$ of age were 49, $32,46,59$ and 60 , respectively. 

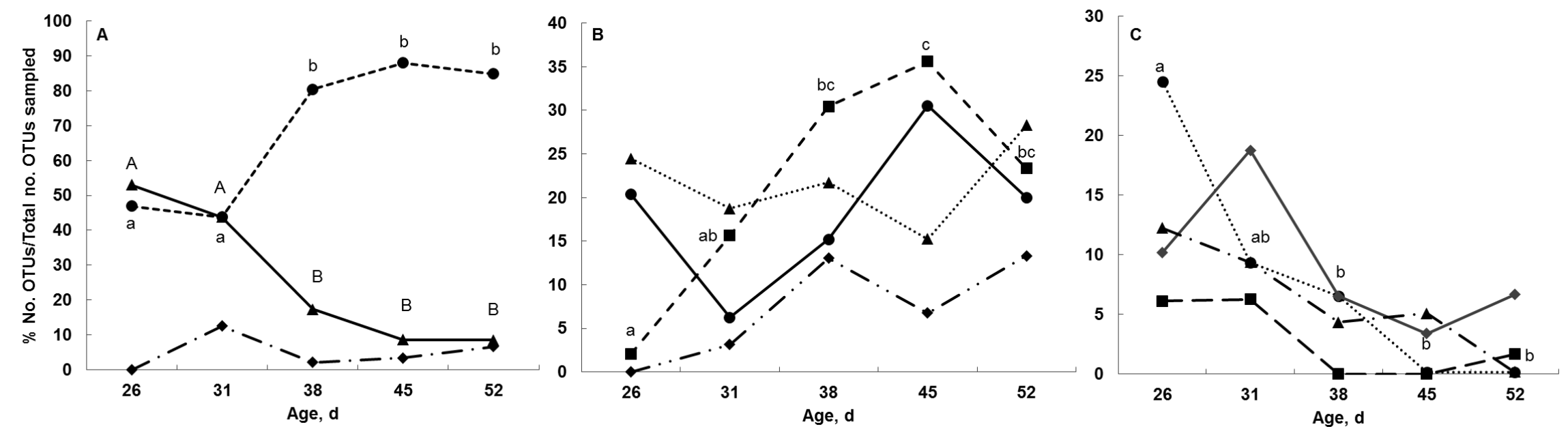

Figure 3. Evolution of caecal microbiota after weaning (26 d) measured as operational taxonomic units (OTUs). A. Phylum: $\mathbf{\Delta}$ Bacteroidetes, $\mathrm{P}_{\mathrm{age}}<0.001$. Firmicutes, $\mathrm{P}_{\mathrm{age}}<0.001$. Verrumicrobia, $\mathrm{P}_{\mathrm{age}}=0.055$. Lower case and capital letters indicate differences for Firmicutes and Bacteroidetes proportions, respectively, with age. B. Families from Firmicutes phylum: $\mathbf{\Delta}$ Lachnospiraceae, $\mathrm{P}_{\mathrm{age}}=0.50$. $\bullet$ Ruminococcaceae, $\mathrm{P}_{\mathrm{age}}=0.056$. Unidentified Clostridiales, $\mathrm{P}_{\mathrm{age}}<0.001$. Unidentified Firmicutes, $\mathrm{P}=0.058$. Lower case letters indicate differences for unidentified Clostridiales proportion with age. C. Families from Bacteroidetes phylum: $\bullet$ Bacteroidaceae, $\mathrm{P}_{\mathrm{age}}<0.001$. Porphyromonadaceae, $\mathrm{P}_{\mathrm{age}}=0.16$. Rikenallaceae, $\mathrm{P}_{\mathrm{age}}=0.12$. $\boldsymbol{\Delta}$ Unidentified Bacteroidales, $\mathrm{P}_{\mathrm{age}}=0.06$. Lower case letters indicate differences for Bacteroidaceae proportion with age. Number of total OTUs at 26, 31, 38, 45 and 52 d of age were 49, 32, 46, 59 and 60, respectively 

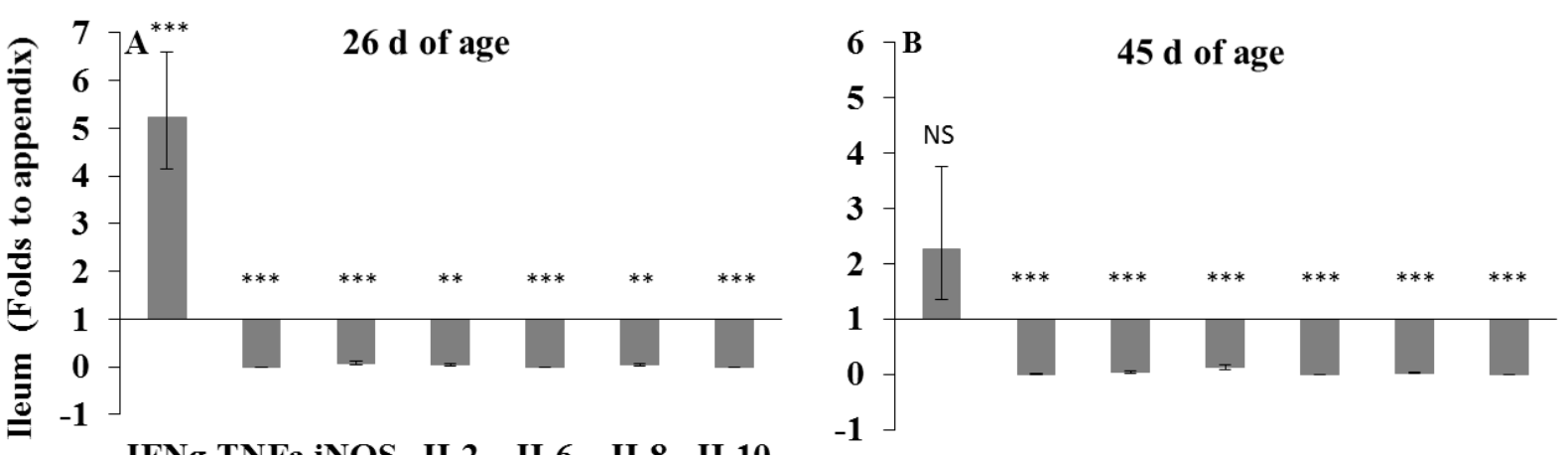

IFNg TNFa iNOS IL2 IL6 IL8 IL10

IFNg TNFa iNOS IL2 IL6 IL8 IL10
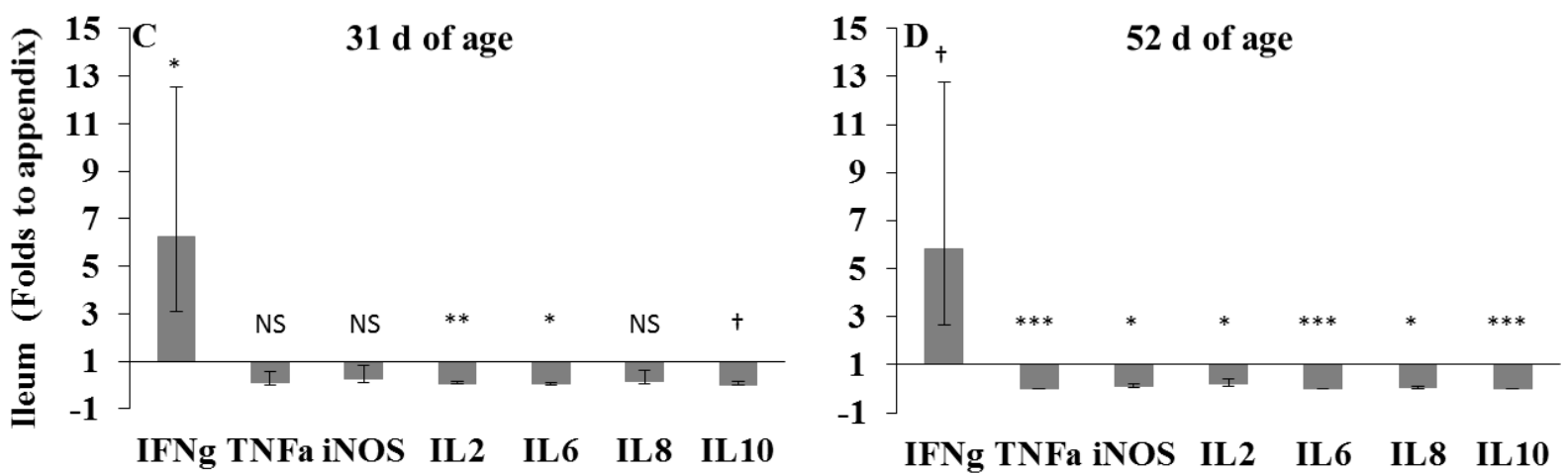

IFNg TNFa iNOS IL2 IL6 IL8 IL10

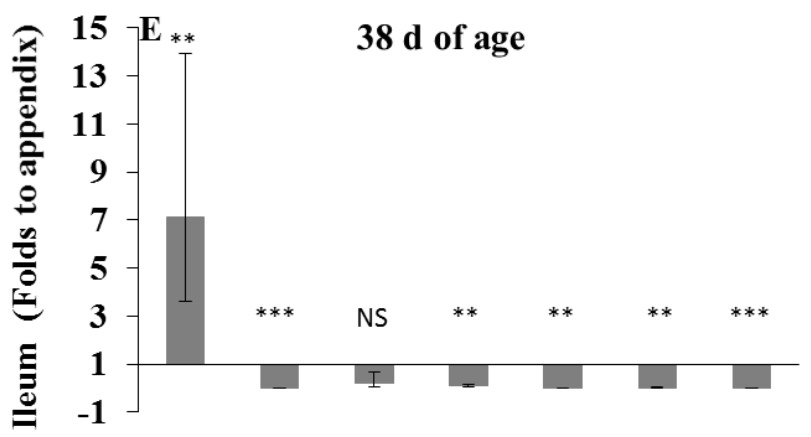

Cytokines/interleukines

IFNg TNFa iNOS IL2 IL6 IL8 IL10

Cytokines/interleukines

Figure 4. Relative gene expression values of ileum relative to appendix set to be 1.0 of interferon-gamma (IFN- $\gamma$ ), tumor necrosis factor-alpha (TNF- $\alpha$ ), inducible nitric oxide synthase (iNOS), interleukin 2 (IL-2), interleukin 6 (IL-6), interleukin 8 (IL-8) and interleukin 10 (IL-10) at 26, 31, 38, 45 and $52 \mathrm{~d}$ of age. Bars indicate the $95 \%$ confidence interval (Fold change up - Fold change low). $(n=5)$ lower case letters indicate differences of expression among ages. $\left({ }^{\dagger} 0.1<\mathrm{P}<0.05 ; *\right.$ : $\mathrm{P}<0.05 ; * \mathrm{P}<0.01 ; * * *$ : $\left.\mathrm{P}<0.001\right)$. 


\section{Appendix}

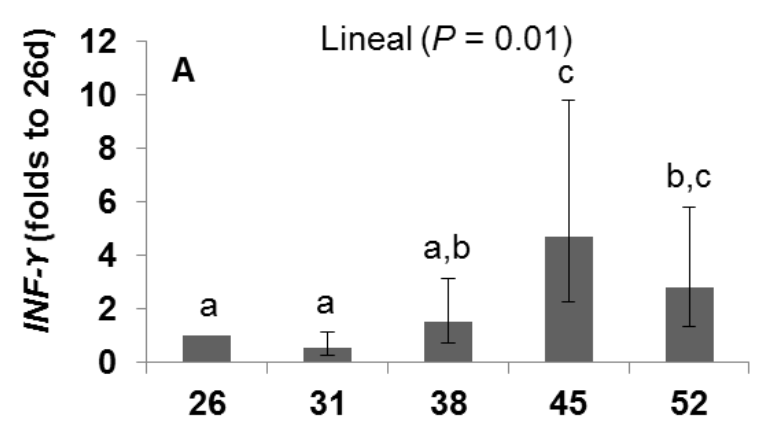

Lineal $(P=0.003)$
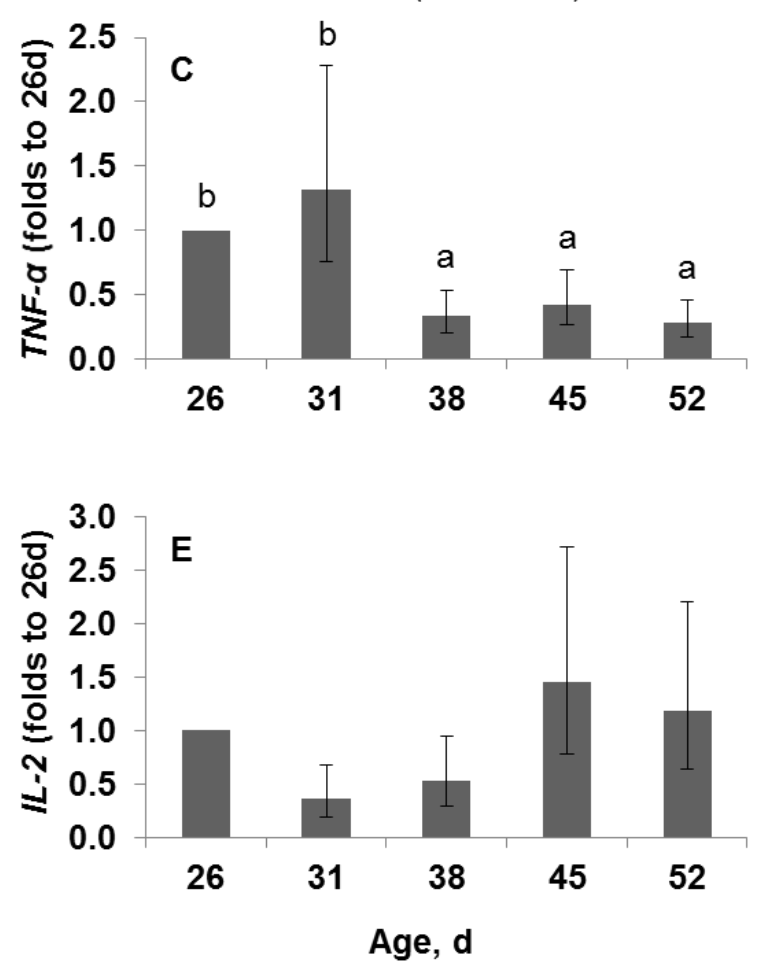

Ileum

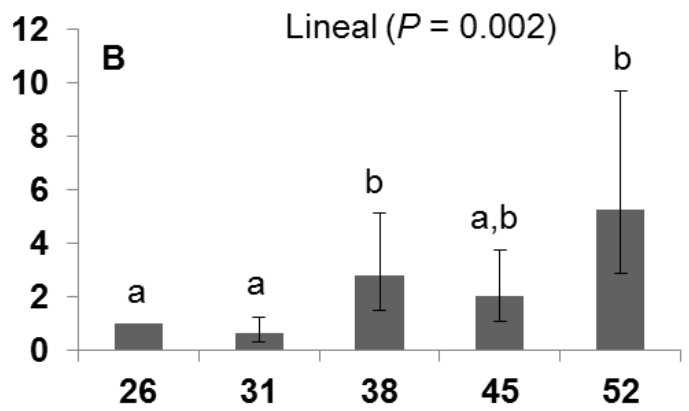

Quadratic $(P=0.03)$

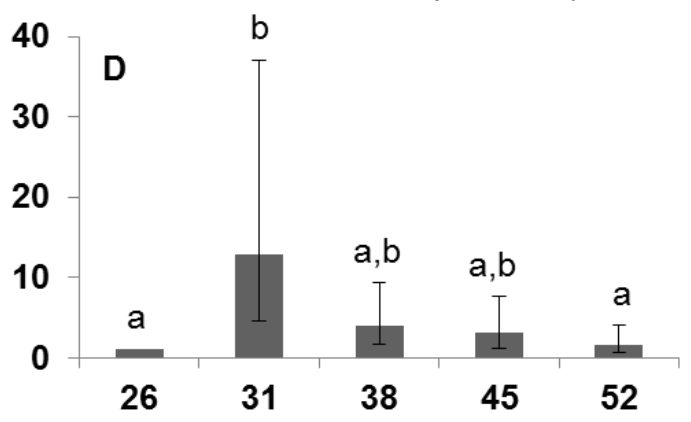

Lineal $(P<0.001)$

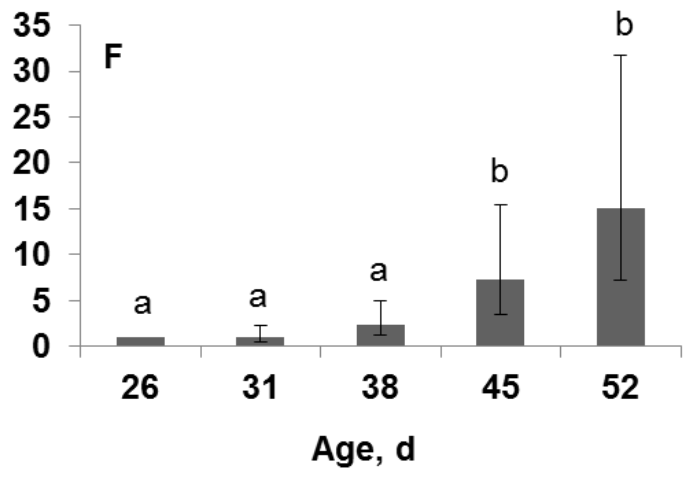

Figure 5. Effect of age on mRNA levels of interferon-gamma (IFN- $\gamma$ ), tumor necrosis factor-alpha (TNF- $\alpha$ ) and interleukin 2 (IL-2) in the rabbit appendix and ileum. Relative gene expression values are fold change of $31,38,45$ and $52 \mathrm{~d}$ of age relative to the control diet (26d) set to be 1.0. Bars indicate the 95\% confidence interval (Fold change up - Fold change low $).(n=5)$ lower case letters indicate differences of expression among ages. 
Chapter 3

Arginine and glutamine dietary supplementation 



\subsection{Effect of dietary supplementation with arginine and glutamine on the performance of rabbit does and their litters during the first three lactations.}

\subsubsection{Introduction.}

Litter size has a great economic importance in rabbit farms (Cartuche et al., 2014). It is affected mainly by ovulation rate and prenatal survival rate, being the latter around 0.35 both in rabbit does and in sows (Blasco et al., 1993). In rabbits, when the number of fetuses increases the vascular supply to each implantation site is reduced (Duncan, 1969). This limited blood supply may produce smaller fetuses and a higher fetal mortality rate, reducing litter weight and size at birth (Argente et al., 2003).

Arginine (Arg) and glutamine (Gln) play an important role in placental, embryonic and fetal growth during pregnancy. Arginine is used as a precursor for the synthesis of nitric oxide (NO), polyamines and other compounds (Wu and Morris, 1998). Nitric oxide plays an important role in vasodilatation and regulates the uterine blood flow promoting the transference of nutrients to the fetus (Moncada and Higgs, 1995; Bird et al., 2003). In sows during early gestation the concentration of Arg in the uterine fluids increased compared to maternal uterine plasma levels (Wu et al., 1998). This rise coincides with the time where the development of the placenta is faster (Wu et al., 2005) and suggest that both nitric oxide and polyamines are key regulators of angiogenesis and embryogenesis as well as placental and fetal growth (Wu et al., 2004a). Arginine supplementation during early gestation (around $8 \mathrm{~g} / \mathrm{kg}$ and 14-28 d pregnancy) in gilts improved fetal survival (Berard and Bee, 2010) whereas its supplementation (10 g/kg) from day 30 of pregnancy to parturition increased the number of piglets born alive and their live weight (Mateo et al., 2007).

Free Gln is abundant in plasma, milk and fetal fluids (Wu, 2009), although the Gln uptake by porcine mammary glands in not adequate for milk protein synthesis (Li et al., 2009). Furthermore, the uterine uptake of Gln in pregnant gilts is the highest compared to other amino acids (Wu et al., 1999). The supplementation of lactating sows diet with $10 \mathrm{~g} \mathrm{Gln} / \mathrm{kg}$ increased its concentration in milk and enhanced piglet growth and survival (Wu et al., 2011). However, the requirements of Arg and Gln have not been studied in rabbit does although the prolificacy increase and nutrient supply may be limited during the pregnancy and lactation. 
The aim of this work was to study the effect of supplementation with Arg and Gln and their potential additive effect on the digestibility, productivity and body composition of rabbit does during the first three parturitions.

\subsubsection{Materials and methods.}

\subsubsection{Experimental diets.}

Four diets in a $2 \times 2$ factorial arrangement were used (two levels of arginine combined with two levels of glutamine). A Control diet was formulated to contain $29.8 \mathrm{~g}$ nitrogen $(\mathrm{N}) / \mathrm{kg} \mathrm{DM}$ and $313 \mathrm{~g} \mathrm{NDF} / \mathrm{kg} \mathrm{DM}$, with a minimal digestible nitrogen to digestible energy (DE) ratio (g/MJ) of 1.84 (Xiccato and Trocino, 2010) and meeting the minimal nutrient requirements (De Blas and Mateos, 2010). Arginine:lysine ratio (in total basis) was fixed in $120 \%$ according to previous recommendations (INRA, 1984), that is higher than the recommended for sows (53\% on average; NRC; 2012) and the ratio Gln:lysine was fixed in 331\%, close to the Control diet used by Baylos et al. (2008). Other three diets were obtained by adding to the Control diet $4 \mathrm{~g}$ arginine/kg (Arg), $4 \mathrm{~g}$ glutamine $/ \mathrm{kg}(\mathrm{Gln})$ and a mixture of $4 \mathrm{~g}$ arginine and $4 \mathrm{~g}$ glutamine $/ \mathrm{kg}$ (Arg+Gln). These treatments resulted in an increase of the Arg:lysine and Gln: lysine ratios in a 15 and 37\%. These doses were fixed according the positive effect observed of the supplementation with $5 \mathrm{~g} \mathrm{Gln} / \mathrm{kg}$ on rabbit intestinal health (increase of the Gln: lysine ratio by $17 \%$; Baylos et al., 2008). The ingredient composition of Control diet is shown in Table 1, and chemical composition of experimental diets in Table 2.

\subsubsection{Lactation trial.}

Eighty nulliparous rabbit does New Zealand White x Californian (line V from UPV) were assigned randomly to the four treatments (20 per diet) at $123 \mathrm{~d}$ of age, six days before the first artificial insemination (AI), with a body weight (BW) of $3.6 \pm 0.1 \mathrm{~kg}$ and with a body composition $(\mathrm{g} / \mathrm{kg} \mathrm{BW}): 619 \pm 16.6$ moisture, $182 \pm 2.6$ protein, $130 \pm 17.3$ fat, $32.2 \pm 0.7$ ash and 10.4 $\pm 0.7 \mathrm{MJ}$ gross energy $/ \mathrm{kg} \mathrm{BW}$ (mean \pm standard deviation). After birth, does were inseminated $11 \mathrm{~d}$ after parturition corresponding to a theoretical kindling-to-kindling interval of $42 \mathrm{~d}$ and the weaning was at $25 \mathrm{~d}$ of lactation. Adoptions were made after parturition among rabbit does belonging to the same diets resulting an average litter size of $10.2 \pm 2.8$ kits. In order to synchronize oestrus, 48 hours before insemination, the does were injected 25 IU of equine chorionic gonadotropin (Segiran, Lab. Ovejero, León) (Rebollar et al., 2006). The day of insemination, does received an 
intramuscular injection of $1 \mu \mathrm{g}$ of buserelin Suprefact ${ }^{\circledR}$ (Hoechst Marison Roussel, S.A., Madrid). Buserelin is a Gonadotropin-releasing hormone agonist (GnRH agonist) used to induce ovulation in rabbit does (Quintela et al., 2004). The semen came from rabbit males of the R line (UPV).

The experimental period began the day of the first insemination of nulliparous rabbit does and finished the day of the parturition that corresponded to the fifth insemination. Live weight, feed intake, reproductive traits and body composition were recorded (at insemination, just after parturition and at weaning) for the first five consecutive cycles (derived from the first scheduled five inseminations) in order to obtain data from the first three lactation periods. Only rabbit does that completed at least two lactations were considered in the analysis (56 does with three lactations and 2 does with 2 lactations). Fourteen rabbit does completed four or five consecutive parturitions, but only were considered for statistical purposes the first three parturitions. The whole information about body condition of these 14 rabbit does is shown in Figure 1B. The bioelectrical impedance analysis technique was used to determine the chemical body composition and energy content of the does (Nicodemus et al., 2009; Pereda, 2010). Measurements of resistance and reactance were taken in rabbit does with a body composition analyzer (Model Quantum II, RJL Systems, Detroit, MI, USA) few hours after parturition, at insemination and at weaning (always after suckling), according to Romero et al. (2011). Multiple regression equations according to Nicodemus et al. (2009) were used to estimate water, protein, ash, fat and energy proportions with respect to the body weight of rabbit does. Fertility was expressed as 100/number of scheduled AI (every 42 days) performed until fertile kindling. Prolificacy (total number of rabbits born alive and dead) were also measured. Mortality of young rabbits was recorded daily during lactation and was calculated as the percentage of rabbits dead with respect to the number of rabbits born alive, using the litter as experimental unit. Mortality of rabbit does was also recorded throughout the first three reproductive cycles. Does were separated from their litters after parturition. Milk production was estimated daily from weight loss of does during suckling (10 min, once a day). Litters were moved to another cage at $20 \mathrm{~d}$ of age. They were offered ad libitum the same diet than their mothers and water, and suckled once a day for $10 \mathrm{~min}$ until weaning age ( $25 \mathrm{~d}$ ). During the first gestation until $14 \mathrm{~d}$ before parturition, rabbit does were restricted to approximately $150 \mathrm{~g} / \mathrm{d}$ but afterwards they were 
fed ad libitum along the experiment. Only does that failed to get pregnant were also restricted between weaning and the next insemination.

\subsubsection{Digestibility trial.}

A total of 24 rabbit does (6 per diet) weighing $4.06 \pm 0.30 \mathrm{~kg}$ with an average litter size of $10.4 \pm 1.4$ kits were used to determine the apparent digestibility of dry matter, gross energy, nitrogen and aNDFom. Total faecal output was collected for each doe during four consecutive days (from day 15 to 19 of the third lactation). Feed intake (ad libitum access) was recorded during this period. Faeces were stored at $-20{ }^{\circ} \mathrm{C}$ and later dried at $80^{\circ} \mathrm{C}$ for $48 \mathrm{~h}$ and ground with a $1 \mathrm{~mm}$ screen.

\subsubsection{Housing.}

Rabbit does were housed individually in flat-deck cages $(600 \times 500 \times 320 \mathrm{~mm})$ throughout the trial and kept under controlled environmental conditions with $18-23^{\circ} \mathrm{C}$ and $16 \mathrm{~h}$ daily lighting. An external nestbox $(355 \times 230 \times 360 \mathrm{~mm}$ high $)$ with wood shavings was provided three days before parturition. All the experimental procedures used were approved by the Animal Ethics Committee of the Universidad Politécnica de Madrid, and were in compliance with the Spanish guidelines for care and use of animals in research (BOE, 2013).

\subsubsection{Chemical analysis.}

Procedures of the AOAC (2000) were used to determine the dietary concentrations of DM (934.01), ash (942.05), nitrogen (954.01), ether extract (920.39), starch (amyloglucosidase- $\alpha$-amylase method; method 996.11) and total dietary fibre (985.29). Dietary aNDFom, ADFom and lignin (sa) were determined sequentially using the filter bag system (Ankom Technology, New York, NY). Dietary aNDFom was determined according to Mertens et al. (2002) using a thermo-stable amylase without any sodium sulphite added. Dietary ADFom and ADL were analyzed according to Goering and Van Soest (1970). The soluble fiber was calculated as the difference between total dietary fibre and aNDFom (both corrected for ash and protein). Gross energy was measured by adiabatic bomb calorimeter (model 356, Parr Instrument Company, Moline, IL). Amino acids were determined after acid hydrolysis using a Beckman System 6300HPA AA analyzer (Fullerton, CA). Samples were hydrolyzed in $25 \mathrm{~mL}$ of $\mathrm{HCl} 6 \mathrm{~N}$ with $10 \mathrm{~g} / \mathrm{L}$ of added phenol for $24 \mathrm{~h}$ at $120^{\circ} \mathrm{C}$. For the determination of methionine and cystine, samples were oxidized with performic acid at $0^{\circ} \mathrm{C}$ for $16 \mathrm{~h}$ and then neutralized with $0.5 \mathrm{~g}$ of 
sodium meta-bisulphite before analysis. During acid hydrolysis, tryptophan was destroyed and was not determined.

\subsubsection{Statistical analysis.}

Data of faecal digestibility was analysed as a completely randomized design with level of arginine, glutamine and their interaction as the main sources of variation by using the mixed procedure of SAS (SAS Inst., Cary, NC). Data from total removed, dead and culled does were analysed using a logistic regression (GENMOD procedure of SAS considering a binomial distribution) including the same variables in the model, and the results were transformed from the logit scale. A mixed model for repeated measures analysis was used to analyse the results obtained for the lactation and body composition traits by using the mixed procedure of SAS. The model included the level of arginine, glutamine, parity order, their interactions as fixed effects and the rabbit doe as a random effect (Littell et al., 1996). Parity order indicated for each doe the number of parturitions (at least two) along the experimental period. The number of kits in each period was used as a covariate in the model used for milk production. The evolution of body weight and composition of rabbit does was also analysed considering in the model the time of the events occurred since the beginning of the experiment (e.g. 1st, 2nd, 3rd, 4th and 5th AI) instead of the parturition order. Initial live weight, body composition (protein, fat, moisture, ash) and energy content at $123 \mathrm{~d}$ of age were used as covariates in the model used for body composition and energy content along time of rabbit does. A compound symmetry structure was fitted as it showed the lowest value of the Schwarz Bayesian criterion (Littell et al., 1998). It assumes that measures over time on the same animals had the same variance and that all pairs of measures on the same animal had the same correlation. All data are presented as least-squares means. When interactions were significant $(\mathrm{P}<0.05)$ the Tukey test was used to separate the treatment means.

\subsubsection{Results.}

Treatments had no effect on feed intake during the digestibility trial or throughout the whole experimental period (Tables 3 and 4). Treatments also did not affect apparent faecal DM, gross energy or aNDFom digestibility, but that of $\mathrm{N}$ tended to increase in Gln compared to the Control group $(\mathrm{P}=0.078)$. As expected, amino acid supplementation increased the digestible $\mathrm{N}$ content (23.1 vs. $21.4 \mathrm{~g} / \mathrm{kg} \mathrm{DM} ; \mathrm{P}=0.015)$ and tended to increase the digestible N/DE ratio compared to Control group $(\mathrm{P}=0.077)$. These results 
led to an increase of digestible $\mathrm{N}$ intake during lactation (7.8 vs. $7.1 \mathrm{~g} / \mathrm{d} ; \mathrm{P}=0.005)$, although it was not observed among parturitions. Digestible energy intake during lactation was higher in Gln group than in Control and Arg+Gln groups $(P=0.041)$, whereas no effect was found for Gln supplementation once Arg was already included.

Total number kits born per litter tended to increase in rabbit does supplemented with Arg, and Gln compared to Control and Arg+Gln groups (11.5 vs. 10.6; P = 0.095; Table 5), but no clear effect was observed for the number of kits born alive or dead and, accordingly, on mortality rate at birth $(7.79 \%$ on average; $\mathrm{P}=0.18)$. No effect of treatments was observed on the weight of the litter at birth, although the individual weight of the kits tended to be lower in the Gln supplemented group $(\mathrm{P}=0.10)$. The initial number kits (once made the adoptions) also tended to be higher for Arg and Gln supplemented groups compared to Control and Arg+Gln groups $(\mathrm{P}=0.089)$. This trend was diluted at weaning, where no effect of treatments on the number of weaned rabbits was observed ( 8.76 on average; $\mathrm{P}=0.15$ ) or in the mortality rate during lactation $(11.1 \%$, on average; $\mathrm{P}=0.53$ ). In spite of the lack of differences, the weight of the litters at 20 and $25 \mathrm{~d}$ were higher when compared Arg and Gln supplemented groups to Control and Arg+Gln groups (Arg × Gln interaction: 3.00 vs. $2.85 \mathrm{~kg}$ and 3.77 vs. $3.56 \mathrm{~kg}$, respectively; $\mathrm{P} \leq 0.021)$. No differences were observed in the average weight of kits at 20 or $25 \mathrm{~d}$ of age, average weight gain of kits along lactation or in the kit and litter feed intake between 20 and $25 \mathrm{~d}$ of age. The feed efficiency was not affected by treatments and was on average 0.280 .

Amino acid supplementation did not affect the milk production $(\mathrm{P}=0.18$. Table 6$)$, although it was positively correlated with $\mathrm{DE}$ and digestible $\mathrm{N}$ intake $(\mathrm{r}=0.75 ; \mathrm{P}<0.001)$. Only, Arg supplementation groups tended to decrease milk production from the first to the third lactation period compared the other two groups (Arg $\times$ Parity interaction: $\mathrm{P}=$ 0.085. Data not shown), mainly due to a lower milk production the first $10 \mathrm{~d}$ of lactation $(\mathrm{P}=0.016)$. A trend for this interaction was also observed for fertility that tended to decrease for Arg supplemented does at the second insemination $(\mathrm{P}=0.088)$. Treatments had no effect on the body weight of rabbit does at parturition, insemination or weaning.

There were no significant effects of treatments on body weight, chemical composition and energy content of rabbit does (Table 7). However, rabbit does supplemented with Arg or Gln tended to have a higher body energy content at the third 
insemination and weaning than those from Control and Arg+Gln groups (Arg $\times$ Gln $\times$ Parity interaction: $\mathrm{P} \leq 0.11$. Data not shown).

Amino acid supplementation did not modify the replacement rate of rabbit does that was high (32.9\% on average. Data not shown), most of it due to the mortality just before parturition (31.6\% on average).

Multiparous rabbit does had a higher feed, digestible $\mathrm{N}$ and energy intake, total number of kits born per litter, weight of the litter at birth and at weaning, milk production and feed efficiency than primiparous does (Tables 4, 5 and $6 . \mathrm{P} \leq 0.005$ ), although they showed a similar number of kits at weaning. Fertility rate was lower in the second insemination compared to the first one $(\mathrm{P}=0.001)$. The body weight at parturition and at weaning of multiparous does were higher and body protein proportion lower respect to primiparous does $(\mathrm{P} \leq 0.025)$, whereas the variations of fat proportion depended on the physiological state, with no effect at parturition (Table 7). The temporal evolution with the productive/reproductive events (five reproductive cycles) of body composition, energy content and weight of all the rabbit does considered in this study is showed in Fig 1A (time effect: $\mathrm{P}<0.001$ for all traits). In Fig 1B is represented this evolution but only for rabbit does that had five consecutive and successful inseminations $(n=14)$. These highly productive rabbit does had a similar initial protein content, with a reduced variation along time, but a lower body weight and fat proportion compared to the average obtained considering all the rabbit does $(\mathrm{P}<0.001)$. Highly productive primiparous does trend to mobilized a higher fat proportion from the second insemination until the first weaning compared to the standard does (11.0 vs. $22.8 \% ; \mathrm{P}=0.051)$.

\subsubsection{Discussion.}

The single supplementation with Arg or Gln tended to increase the number of kits born per litter and the litter size once made the adoptions. These results are partially in agreement with the positive effect of Arg supplementation on prolificacy obtained in sows (1\% Arg; +2 piglets; Mateo et al., 2007; 0.8\% Arg; + 3.7 piglets; Berard and Bee, 2010) and rats (1.3\% Arg; +3 rats; Zeng et al., 2008). In rats, Arg supplementation increased the number of implantation sites and the litter size at birth, but in pigs these authors did not found any effect on the total number of piglets born per litter, but a great effect on the piglet survival rate at birth, effect that was not observed in this study. Accordingly, the minor magnitude of the effect of Arg supplementation found in this study might be due 
to the lower dose of Arg employed. Arginine is a common substrate for nitric oxide and polyamine syntheses, and nitric oxide plays an important role in regulating placental-fetal blood flows (Bird et al., 2003), contributing to maternal systemic vasodilatation during pregnancy and regulating the uterine and foetal placental blood flow (Sladek et al., 1997). In this way, recent results obtained in rabbits revealed that the probability of mortality of fetuses is three times higher if they receive a single vein than if they receive two or more veins (Damico et al., 2013). Furthermore, nitric oxide might influence positively the final litter size as it also induced the follicle rupture in vitro in the rabbit ovaries (Yamauchi et al., 1997).

The positive trend observed of Gln supplementation on the initial litter size might be accounted for the benefit of Gln on the in vitro development of oocytes (in hamsters and rabbits; Gwatkin and Haidri, 1973; Bae and Foote, 1975) and embryos (in hamsters and pigs; Carney and Bavister, 1987; Petters et al., 1990), which might be linked to the use of Gln as an energy source. In this sense, Gln was among the most abundant amino acids in the pig follicular fluid and its supplementation in a maturation medium improved fertilization and preimplantation development (Hong and Lee, 2007). Furthermore, Gln (but also Arg) is very abundant in fetal fluids in the first part of pregnancy of sows, when the growth of placenta is more rapid (Wu and Knabe, 1994; Newsholme and Clader, 1997; Self et al., 2004), and it is associated with a high placental nitric oxide and polyamine synthesis and accordingly with foetal development (Wu et al., 2007). However, no positive effect of $1 \%$ Gln in gestating sows was reported on litter size at birth (Wu et al., 2011). Glutamine supplementation in sows, and not Arg, increased the average birth weight of piglets (Mateo et al., 2007; Wu et al., 2011) that contrasts with the trend found in this study in rabbits to reduce it.

Nevertheless, the trend observed on the initial litter size was diluted along the lactation period due to mortality, and no effect of single Arg or Gln supplementation on the litter size at weaning was found. However, the litter size at weaning might be responsible for the higher litter weight at weaning when supplemented only with Arg or Gln, because both variables were positively correlated $(r=0.65 ; \mathrm{P}<0.001)$, and no effect on milk production (only Arg supplemented does tended to reduce milk production at the third lactation) or in the average growth rate of kits during lactation were found. This situation differs from that reported when sows were supplemented with $1 \%$ of Arg or Gln, where the average growth rate of piglets during lactation increased, and Gln 
supplementation also decreased preweaning mortality (Mateo et al., 2008; Wu et al., 2011).

In spite of the heavier litters obtained at weaning when supplemented with Arg or Gln no impairment on body condition was found in rabbit does, and even does of these groups tended to have a greater energy content at the end of the third lactation compared to Control and Arg+Gln groups. It might be related with an improved nitrogen metabolism as Arg supplementation reduced serum/plasmatic urea concentrations in pigs and rats (Mateo et al., 2007; Zeng et al., 2008) or with a spare of branched amino acids when Gln is supplemented, although in this case no influence on plasmatic urea concentrations were observed (Wu et al., 2011).

There was no additive effect of the simultaneous supplementation of Arg and Gln and, in some traits (litter size at birth, litter weight at weaning, or doe energy content at the third lactation), Arg+Gln group tended to show closer values to Control group. There is no previous information about this lack of synergism between Arg and Gln on reproductive traits, although the single supplementation of these amino acids seem to exert different effects on the blood concentration of the other one. The single supplementation of Arg decreased the plasmatic Gln concentration in pregnant gilts (Mateo et al., 2007; Berard and Bee, 2010), whereas the single Gln supplementation increased the plasmatic Arg concentration (Wu et al., 2011). In pregnant rats, the single supplementation of Arg, exerted the opposite effect, and increased the serum Gln concentration (Zeng et al., 2008). In a very different scenario, when the gut barrier function traits are studied the combined supplementation of both amino acids did not improve the single supplementation of Gln in rabbits (Chamorro et al., 2010) or the single supplementation of Arg or Gln in rats (Beutheu et al., 2014).

These results suggest that the physiological period to supplement these amino acids might be different if a synergistic effect is wanted and with a higher dose than the one used in this study. The different way of action of Arg and Gln to promote prolificacy might recommend to supplement Gln few days before insemination until at least embryo implantation (7-8 d after insemination), where fertilization and implantation occurs (Harper, 1961; Denker, 1977), whereas Arg supplementation could be made few days before implantation until the end of pregnancy.

The effects observed for the parity order were those expected and similar to those previously described (Pascual et al., 1999; Xiccato et al., 2004; Rebollar et al., 2009). 
Highly productive does tended to have less fat content at the beginning of the experiment, and showed a numerically lower fat mobilization before the first parturition (but not significant) and a similar fat restoration from birth to next insemination than the average obtained considering all the rabbit does, which agrees with the results reported by Savietto et al. (2016). However, it contrasts with the continuous mobilization of fat reserves along the first lactation reported by Fortun-Lamothe (2006). From the second insemination until the first weaning, highly productive does were able to mobilize in a greater extent their fat reserves compared the average population, and this trend was also observed in successive parturitions. These results question whether the ability of highly productive does in the use of fat reserves accounts for the reproductive success or, on the opposite, the latter is influencing their body condition.

In conclusion, the single supplementation of Arg and Gln had a positive effect on the weight of litters at weaning and litter size at birth. No additive effect was observed for the combined supplementation of Arg and Gln. Further research is required to establish the optimal dose and the best period for their supplementation. 
Table 1. Ingredient composition of the Control diet (g/kg DM).

\begin{tabular}{lc}
\hline Alfalfa hay & 290 \\
Alfalfa hay-Yb & 5 \\
Wheat & 220 \\
Wheat straw & 220 \\
Sunflower meal 28-30 & 130 \\
Soybean meal 44 & 65.0 \\
Soy protein concentrate 61 & 15.0 \\
Defatted grape seed meal & 20.0 \\
Lard & 20.0 \\
L-lysine HCl & 2.00 \\
DL-methionine & 0.50 \\
L-threonine & 0.50 \\
Calcium carbonate & 6.80 \\
Sodium chloride & 5.00 \\
Vitamin $/$ mineral premix $^{1}$ & 5.00 \\
Coccidiostat & \\
\hline
\end{tabular}

${ }^{1}$ Provided by Trouw Nutrition-Tecna (Madrid, España). Mineral and vitamin composition (per $\mathrm{kg}$ of complete diet): $20 \mathrm{mg}$ of $\mathrm{Mn}$ as $\mathrm{MnO} ; 59.2 \mathrm{mg}$ of $\mathrm{Zn}$ as $\mathrm{Zn}$; $10 \mathrm{mg}$ of $\mathrm{Cu}$ as $\mathrm{CuSO}_{4} 5 \mathrm{H}_{2} \mathrm{O} ; 1.25 \mathrm{mg}$ of I as $\mathrm{KI} ; 0.495 \mathrm{mg}$ of $\mathrm{Co}$ as $2 \mathrm{CoCO}_{3}(\mathrm{OH})_{2} \mathrm{H}_{2} \mathrm{O} ; 76 \mathrm{mg}$ of $\mathrm{Fe}$ as $\mathrm{FeCO}_{3} ; 8375 \mathrm{UI}$ of vitamin A; $750 \mathrm{UI}$ of vitamin $\mathrm{D}_{3}, 20 \mathrm{UI}$ of vitamin $\mathrm{E}$ as DL- $\alpha$-tocopherol acetate, $1.0 \mathrm{mg}$ of vitamin $\mathrm{K} ; 1.0 \mathrm{mg}$ of vitamin $\mathrm{B}_{1} ; 2 \mathrm{mg}$ of vitamin $\mathrm{B}_{2} ; 1 \mathrm{mg}$ of vitamin $\mathrm{B}_{6} ; 20 \mathrm{mg}$ of Niacin; $54.1 \mathrm{mg}$ of Betaine; 137,5 mg of Choline chloride.

${ }^{2} 1 \mathrm{ppm}$ diclazuril provided by Esteve (España). 
Table 2. Chemical composition of experimental diets (g/kg DM).

\begin{tabular}{|c|c|c|c|c|}
\hline Diets $^{1}$ & $\mathrm{C}$ & Arg & Gln & Arg+Gln \\
\hline Arginine, $\mathrm{g} / \mathrm{kg}$ & 0 & 4 & 0 & 4 \\
\hline Glutamine, $\mathrm{g} / \mathrm{kg}$ & 0 & 0 & 4 & 4 \\
\hline \multicolumn{5}{|l|}{ Analyzed composition, g/kg DM } \\
\hline Dry matter & 899 & 893 & 897 & 901 \\
\hline Ash & 67.5 & 71.2 & 68.9 & 71.0 \\
\hline Nitrogen & 29.8 & 30.6 & 30.1 & 30.4 \\
\hline Ether extract & 50.0 & 50.0 & 47.0 & 45.0 \\
\hline Starch & 189 & 191 & 181 & 181 \\
\hline Total dietary fibre & 418 & 423 & 426 & 425 \\
\hline Neutral detergent fibre & 313 & 322 & 319 & 321 \\
\hline Acid detergent fibre & 179 & 174 & 176 & 179 \\
\hline Acid detergent lignin & 48.1 & 44.6 & 45.6 & 44.1 \\
\hline Soluble fibre & 105 & 101 & 107 & 105 \\
\hline Gross energy (MJ/kg DM) & 18.0 & 18.5 & 18.4 & 18.4 \\
\hline \multicolumn{5}{|l|}{ Amino acids, $\mathrm{g} / \mathrm{kg} \mathrm{DM}$} \\
\hline Alanine & 8.00 & 7.90 & 8.00 & 8.00 \\
\hline Arginine & 11.3 & 15.3 & 11.6 & 15.3 \\
\hline Aspartic acid & 16.1 & 16.0 & 15.9 & 16.1 \\
\hline Cystine & 2.90 & 2.90 & 2.90 & 2.90 \\
\hline Glutamic acid & 30.8 & 30.3 & 34.5 & 35.3 \\
\hline Glycine & 8.70 & 8.60 & 8.70 & 8.70 \\
\hline Histidine & 4.00 & 3.90 & 4.00 & 3.90 \\
\hline Isoleucine & 6.90 & 6.70 & 6.80 & 6.60 \\
\hline Leucine & 11.9 & 11.8 & 11.8 & 11.9 \\
\hline Lysine & 9.30 & 9.20 & 9.20 & 9.20 \\
\hline Methionine & 3.30 & 3.20 & 3.20 & 3.20 \\
\hline Phenylalanine & 8.10 & 8.00 & 8.10 & 8.00 \\
\hline Proline & 10.4 & 10.3 & 10.3 & 10.4 \\
\hline Serine & 7.90 & 7.80 & 7.70 & 8.10 \\
\hline Threonine & 7.00 & 6.90 & 6.80 & 7.00 \\
\hline Valine & 8.50 & 8.30 & 8.40 & 8.20 \\
\hline
\end{tabular}


Table 3. Effect of type of arginine and glutamine supplementation on feed intake and faecal apparent digestibility of nutrients in rabbit does at 21 $\mathrm{d}$ of lactation of the third parturition.

\begin{tabular}{|c|c|c|c|c|c|c|c|c|}
\hline & \multicolumn{4}{|c|}{ Diets $^{1}$} & \multirow[t]{2}{*}{ rsd } & \multicolumn{3}{|c|}{ P-value } \\
\hline & $\mathrm{C}$ & Arg & Gln & Arg+Gln & & Arg & Gln & $\operatorname{Arg} \times \mathrm{Gln}$ \\
\hline Arginine, $\mathrm{g} / \mathrm{kg}$ & 0 & 4 & 0 & 4 & & & & \\
\hline Glutamine, $\mathrm{g} / \mathrm{kg}$ & 0 & 0 & 4 & 4 & & & & \\
\hline Number of rabbit does & 6 & 6 & 6 & 6 & & & & \\
\hline Feed intake, g DM/day & 322 & 340 & 325 & 327 & 41.6 & 0.58 & 0.78 & 0.65 \\
\hline \multicolumn{9}{|l|}{ Faecal apparent digestibility } \\
\hline Dry matter & 0.622 & 0.633 & 0.636 & 0.630 & 0.014 & 0.67 & 0.41 & 0.15 \\
\hline Gross energy & 0.629 & 0.637 & 0.643 & 0.635 & 0.014 & 0.91 & 0.31 & 0.19 \\
\hline Nitrogen & 0.720 & 0.745 & 0.753 & 0.745 & 0.022 & 0.37 & 0.086 & 0.078 \\
\hline Neutral detergent fibre & 0.231 & 0.254 & 0.243 & 0.251 & 0.034 & 0.27 & 0.76 & 0.58 \\
\hline Digestible energy, MJ/kg DM & 11.6 & 11.8 & 11.8 & 11.7 & 0.26 & 0.82 & 0.45 & 0.12 \\
\hline Digestible nitrogen, g/kg DM & $21.4^{\mathrm{a}}$ & $23.3^{\mathrm{b}}$ & $22.8^{\mathrm{b}}$ & $23.2^{\mathrm{b}}$ & 0.069 & $<0.001$ & 0.036 & 0.015 \\
\hline Ratio digestible [nitrogen/energy], g/MJ & 1.85 & 1.98 & 1.93 & 1.99 & 0.045 & $<0.001$ & 0.038 & 0.077 \\
\hline
\end{tabular}

${ }^{1} \mathrm{C}=$ control diet; $\mathrm{Arg}=0.4 \%$ arginine dietary supplementation; $\mathrm{Gln}=0.4 \%$ glutamine dietary supplementation; $\mathrm{Arg}+\mathrm{Gln}=0.4 \%$ arginine $+0.4 \%$ glutamine supplementation.

${ }^{\mathrm{a}-\mathrm{c}}$ Diet mean values in the same row with a different superscript differ, $\mathrm{P}<0.05$. 
Table 4. Effect of arginine and glutamine supplementation and parity order on digestible energy and nitrogen intake of rabbit does.

\begin{tabular}{|c|c|c|c|c|c|c|c|c|c|c|c|c|}
\hline & \multicolumn{4}{|c|}{ Diets $^{1}$} & \multicolumn{3}{|c|}{ Parity order } & \multirow[t]{5}{*}{ rsd } & \multicolumn{4}{|c|}{ P-value ${ }^{2}$} \\
\hline & $\mathrm{C}$ & Arg & Gln & Arg+Gln & 1 & 2 & 3 & & $\operatorname{Arg}$ & Gln & Arg $\times$ Gln & Parity \\
\hline Arginine, $\mathrm{g} / \mathrm{kg}$ & 0 & 4 & 0 & 4 & & & & & & & & \\
\hline Glutamine, $\mathrm{g} / \mathrm{kg}$ & 0 & 0 & 4 & 4 & & & & & & & & \\
\hline Number of rabbit does & 14 & 14 & 15 & 15 & 58 & 58 & 56 & & & & & \\
\hline \multicolumn{13}{|l|}{ Feed intake of rabbit does, $g / d$} \\
\hline Artificial insemination1-parturition1 & 163 & 150 & 155 & 149 & - & - & - & 22.1 & 0.11 & 0.40 & 0.53 & - \\
\hline Parturition-artificial insemination & 283 & 274 & 287 & 289 & $268^{\mathrm{a}}$ & $285^{\mathrm{ab}}$ & $298^{\mathrm{b}}$ & 41.7 & 0.68 & 0.25 & 0.51 & 0.003 \\
\hline Lactation $(0-25 \mathrm{~d})$ & 332 & 336 & 349 & 333 & $320^{\mathrm{a}}$ & $335^{\mathrm{a}}$ & $359^{\mathrm{b}}$ & 38.6 & 0.37 & 0.33 & 0.16 & $<0.001$ \\
\hline Weaning $(25 \mathrm{~d})$ - next parturition & 185 & 172 & 177 & 180 & 167 & 190 & - & 33.4 & 0.53 & 0.97 & 0.33 & $<0.001$ \\
\hline Among parturitions & 249 & 251 & 258 & 256 & 240 & 266 & - & 37.2 & 0.99 & 0.40 & 0.85 & $<0.001$ \\
\hline \multicolumn{13}{|c|}{ Digestible energy intake of rabbit does, MJ/d } \\
\hline Artificial insemination1-parturition1 & 1.89 & 1.77 & 1.83 & 1.74 & - & - & - & 0.26 & 0.12 & 0.52 & 0.82 & - \\
\hline Parturition-artificial insemination & 3.27 & 3.23 & 3.40 & 3.38 & $3.14^{\mathrm{a}}$ & $3.34^{\mathrm{ab}}$ & $3.48^{\mathrm{b}}$ & 0.49 & 0.73 & 0.16 & 0.87 & 0.003 \\
\hline Lactation $(0-25 \mathrm{~d})$ & 3.84 & 3.95 & 4.13 & 3.90 & $3.74^{\mathrm{a}}$ & $3.92^{\mathrm{a}}$ & $4.20^{\mathrm{b}}$ & 0.47 & 0.44 & 0.18 & 0.041 & $<0.001$ \\
\hline Weaning $(25 \mathrm{~d})$ - next parturition & 2.13 & 2.02 & 2.10 & 2.10 & 1.95 & 2.23 & - & 0.39 & 0.55 & 0.82 & 0.52 & $<0.001$ \\
\hline Among parturitions & 2.88 & 2.95 & 3.05 & 2.99 & 2.82 & 3.12 & - & 0.44 & 0.94 & 0.28 & 0.51 & $<0.001$ \\
\hline \multicolumn{13}{|c|}{ Digestible nitrogen intake of rabbit does, $\mathrm{g} / \mathrm{d}$} \\
\hline Artificial insemination1-parturition1 & 3.49 & 3.49 & 3.53 & 3.45 & - & - & - & 0.51 & 0.77 & 0.97 & 0.78 & - \\
\hline Parturition-artificial insemination & 6.06 & 6.39 & 6.55 & 6.72 & $6.08^{\mathrm{a}}$ & $6.46^{\mathrm{ab}}$ & $6.74^{\mathrm{b}}$ & 0.95 & 0.20 & 0.036 & 0.67 & 0.004 \\
\hline Lactation $(0-25 \mathrm{~d})$ & $7.11^{\mathrm{a}}$ & $7.83^{b}$ & $7.97^{\mathrm{b}}$ & $7.74^{\mathrm{b}}$ & $7.25^{\mathrm{a}}$ & $7.60^{\mathrm{a}}$ & $8.14^{\mathrm{b}}$ & 0.91 & 0.13 & 0.022 & 0.005 & $<0.001$ \\
\hline Weaning $(25 \mathrm{~d})$ - next parturition & 3.95 & 4.00 & 4.04 & 4.18 & 3.77 & 4.31 & - & 0.74 & 0.59 & 0.44 & 0.80 & $<0.001$ \\
\hline Among parturitions & 5.33 & 5.84 & 5.87 & 5.94 & 5.45 & 6.04 & - & 0.84 & 0.11 & 0.084 & 0.23 & $<0.001$ \\
\hline
\end{tabular}

${ }^{1} \mathrm{C}=$ control diet; $\mathrm{Arg}=0.4 \%$ arginine dietary supplementation; $\mathrm{Gln}=0.4 \%$ glutamine dietary supplementation; Arg+Gln $=0.4 \%$ arginine $+0.4 \%$ glutamine supplementation. ${ }^{2}$ No significant differences $(\mathrm{P} \geq 0.14)$ were found when the interaction $\operatorname{Arg} \times \mathrm{Gln} \times$ Parity was analyzed. ${ }^{\mathrm{a}-\mathrm{c}}$ Parity order mean values in the same row with a different superscript differ, $\mathrm{P}<0.05$. 
Table 5. Effect of arginine and glutamine supplementation and parity order on performance of rabbit does and their litters.

\begin{tabular}{|c|c|c|c|c|c|c|c|c|c|c|c|c|}
\hline & \multicolumn{4}{|c|}{ Diets $^{1}$} & \multicolumn{3}{|c|}{ Parity order } & \multirow[t]{5}{*}{$\mathrm{rsd}$} & \multicolumn{4}{|c|}{ P-value ${ }^{2}$} \\
\hline & $\mathrm{C}$ & $\operatorname{Arg}$ & Gln & Arg+Gln & 1 & 2 & 3 & & Arg & Gln & $\operatorname{Arg} \times \mathrm{Gln}$ & Parity \\
\hline Arginine, $\mathrm{g} / \mathrm{kg}$ & 0 & 4 & 0 & 4 & & & & & & & & \\
\hline Glutamine, $\mathrm{g} / \mathrm{kg}$ & 0 & 0 & 4 & 4 & & & & & & & & \\
\hline Number of rabbit does & 14 & 14 & 15 & 15 & 58 & 58 & 56 & & & & & \\
\hline \multicolumn{13}{|l|}{ Number of kits per litter } \\
\hline Total born & 10.3 & 11.6 & 11.3 & 10.9 & $9.88^{\mathrm{a}}$ & $11.2^{\mathrm{ab}}$ & $12.0^{\mathrm{b}}$ & 3.14 & 0.32 & 0.68 & 0.095 & 0.005 \\
\hline Born alive & 9.58 & 10.5 & 10.5 & 10.2 & 9.30 & 10.5 & 10.8 & 3.19 & 0.55 & 0.55 & 0.22 & 0.055 \\
\hline Born dead & 0.66 & 1.10 & 0.80 & 0.79 & $0.58^{\mathrm{a}}$ & $0.69^{\mathrm{ab}}$ & $1.24^{\mathrm{b}}$ & 1.20 & 0.30 & 0.68 & 0.27 & 0.028 \\
\hline Initial number (once homogenized) & 9.52 & 10.3 & 10.3 & 9.81 & 9.50 & 10.2 & 10.2 & 2.30 & 0.65 & 0.74 & 0.089 & 0.19 \\
\hline $20 \mathrm{~d}$ lactation & 8.40 & 8.95 & 9.07 & 8.80 & 8.59 & 9.17 & 8.66 & 2.01 & 0.65 & 0.40 & 0.20 & 0.30 \\
\hline $25 \mathrm{~d}$ (weaning) & 8.30 & 8.92 & 9.05 & 8.78 & 8.54 & 9.11 & 8.64 & 1.98 & 0.57 & 0.31 & 0.15 & 0.32 \\
\hline Mortality at birth, $\%$ & 6.11 & 8.85 & 9.60 & 6.59 & 6.31 & 5.98 & 11.1 & 12.9 & 0.95 & 0.77 & 0.18 & 0.13 \\
\hline Mortality during lactation, \% & 11.3 & 12.2 & 11.2 & 9.73 & $9.49^{\mathrm{a}}$ & $9.65^{\mathrm{a}}$ & $14.2^{\mathrm{b}}$ & 10.2 & 0.89 & 0.49 & 0.53 & 0.040 \\
\hline \multicolumn{13}{|l|}{ Weight of the litter, $\mathrm{kg}$} \\
\hline Weight of litter at birth, $\mathrm{kg}$ & 0.543 & 0.590 & 0.567 & 0.544 & $0.474^{\mathrm{a}}$ & $0.591^{\mathrm{b}}$ & $0.618^{b}$ & 0.14 & 0.63 & 0.64 & 0.13 & $<0.001$ \\
\hline $20 \mathrm{~d}$ & 2.85 & 3.00 & 3.00 & 2.85 & $2.68^{\mathrm{a}}$ & $3.04^{\mathrm{b}}$ & $3.06^{\mathrm{b}}$ & 0.35 & 0.99 & 0.99 & 0.021 & $<0.001$ \\
\hline $25 \mathrm{~d}$ (weaning) & 3.56 & 3.76 & 3.78 & 3.56 & $3.31^{\mathrm{a}}$ & $3.88^{\mathrm{b}}$ & $3.81^{\mathrm{b}}$ & 0.46 & 0.88 & 0.91 & 0.016 & $<0.001$ \\
\hline \multicolumn{13}{|l|}{ Weight of the kits, $g$} \\
\hline Birth & 60.5 & 57.2 & 53.6 & 56.2 & 54.6 & 58.0 & 58.0 & 13.4 & 0.88 & 0.10 & 0.22 & 0.32 \\
\hline $20 \mathrm{~d}$ & 353 & 344 & 350 & 340 & 332 & 341 & 367 & 71.8 & 0.46 & 0.76 & 1.00 & 0.082 \\
\hline $25 \mathrm{~d}$ (weaning) & 445 & 430 & 441 & 427 & $411^{\mathrm{a}}$ & $436^{\mathrm{ab}}$ & $461^{\mathrm{b}}$ & 89.2 & 0.38 & 0.82 & 1.00 & 0.042 \\
\hline Kits average daily gain $0-25, \mathrm{~g} / \mathrm{d}$ & 15.0 & 14.5 & 15.1 & 14.5 & $14.1^{\mathrm{a}}$ & $14.8^{\mathrm{a}}$ & $15.4^{\mathrm{b}}$ & 4.62 & 0.37 & 0.97 & 0.98 & 0.22 \\
\hline Kits feed intake $20-25 \mathrm{~d}, \mathrm{~g} / \mathrm{d}$ & 7.16 & 7.86 & 7.55 & 7.35 & $8.60^{\mathrm{b}}$ & $5.94^{\mathrm{a}}$ & $7.90^{\mathrm{b}}$ & 3.26 & 0.67 & 0.92 & 0.46 & $<0.001$ \\
\hline Litter feed intake $20-25 \mathrm{~d}, \mathrm{~g} / \mathrm{d}$ & 59.8 & 63.8 & 68.5 & 64.5 & $75.1^{\mathrm{b}}$ & $54.1^{\mathrm{a}}$ & $63.2^{\mathrm{ab}}$ & 34.1 & 0.99 & 0.39 & 0.47 & 0.006 \\
\hline $\begin{array}{l}\text { Feed efficiency, } \mathrm{kg} \text { weaned/ } \mathrm{kg} \text { feed doe } \\
\text { among parturition+ kits }\end{array}$ & 0.278 & 0.284 & 0.282 & 0.275 & 0.260 & 0.299 & - & 0.06 & 0.98 & 0.87 & 0.65 & $<0.001$ \\
\hline
\end{tabular}

${ }^{1} \mathrm{C}=$ control diet; $\mathrm{Arg}=0.4 \%$ arginine dietary supplementation; Gln $=0.4 \%$ glutamine dietary supplementation; Arg+Gln $=0.4 \%$ arginine $+0.4 \%$ glutamine supplementation. ${ }^{2} \mathrm{No}$ significant differences $(\mathrm{P} \geq 0.25)$ were found when the interactions Arg $\times$ Parity, Gln $\times$ Parity and Arg $\times$ Gln $\times$ Parity. ${ }^{\text {a-c }}$ Diet mean values in the same row with a different superscript differ. $\mathrm{P}<0.05$ 
Table 6. Effect of arginine and glutamine supplementation and parity order on doe weight, fertility and milk production of rabbit does.

\begin{tabular}{|c|c|c|c|c|c|c|c|c|c|c|c|c|c|c|c|c|}
\hline \multirow[b]{3}{*}{ Arginine, $\mathrm{g} / \mathrm{kg}$} & \multicolumn{4}{|c|}{ Diets $^{1}$} & \multicolumn{4}{|c|}{ Parity order } & \multirow[t]{5}{*}{ rsd } & \multicolumn{7}{|c|}{$\mathrm{P}$-value ${ }^{3}$} \\
\hline & \multirow{2}{*}{$\begin{array}{l}\mathrm{C} \\
0\end{array}$} & \multirow{2}{*}{$\frac{\operatorname{Arg}}{4}$} & \multirow{2}{*}{$\frac{\mathrm{Gln}}{0}$} & \multirow{2}{*}{$\frac{\operatorname{Arg}+\mathrm{Gln}}{4}$} & \multirow[t]{2}{*}{1} & \multirow[t]{2}{*}{2} & \multirow[t]{2}{*}{3} & \multirow[t]{3}{*}{4} & & \multirow[t]{4}{*}{$\operatorname{Cov}^{2}$} & \multirow[t]{4}{*}{ Arg } & \multirow[t]{4}{*}{ Gln } & \multirow[t]{4}{*}{ Arg $\times$ Gln } & \multirow[t]{4}{*}{ Parity } & \multirow{4}{*}{$\begin{array}{c}\text { Arg } \\
\times \text { Parity }\end{array}$} & \multirow[t]{4}{*}{ Gln $\times$ Parity } \\
\hline & & & & & & & & & & & & & & & & \\
\hline Glutamine, $\mathrm{g} / \mathrm{kg}$ & 0 & 0 & 4 & 4 & & & & & & & & & & & & \\
\hline Number of rabbit does & 14 & 14 & 15 & 15 & 58 & 58 & 56 & 56 & & & & & & & & \\
\hline \multicolumn{17}{|l|}{ Doe weight, $\mathrm{g}$} \\
\hline Parturition & 4049 & 4014 & 4073 & 4049 & $3988^{a}$ & $4068^{\mathrm{ab}}$ & $4083^{\mathrm{b}}$ & - & 313 & - & 0.69 & 0.68 & 0.94 & 0.025 & 0.64 & 0.65 \\
\hline Insemination (11d) & 4079 & 4096 & 4119 & 4141 & $3953^{\mathrm{a}}$ & $4184^{\mathrm{b}}$ & $4163^{\mathrm{b}}$ & $4136^{\mathrm{b}}$ & 326 & - & 0.80 & 0.58 & 0.98 & $<0.001$ & 0.54 & 0.74 \\
\hline Weaning $(25 \mathrm{~d})$ & 4373 & 4363 & 4358 & 4361 & $4294^{\mathrm{a}}$ & $4375^{\mathrm{ab}}$ & $4421^{\mathrm{b}}$ & - & 327 & - & 0.96 & 0.91 & 0.93 & 0.020 & 0.65 & 0.12 \\
\hline Fertility, \% & 92.3 & 90.5 & 88.1 & 90.5 & $96.5^{\mathrm{b}}$ & $83.1^{\mathrm{a}}$ & $91.5^{\mathrm{ab}}$ & - & 20.0 & - & 0.93 & 0.51 & 0.51 & 0.001 & 0.088 & 0.68 \\
\hline \multicolumn{17}{|l|}{ Milk production, $\mathrm{kg}$} \\
\hline $0-10 \mathrm{~d}$ & 1.67 & 1.66 & 1.76 & 1.68 & $1.56^{\mathrm{a}}$ & $1.68^{\mathrm{b}}$ & $1.83^{\mathrm{c}}$ & - & 0.25 & $<0.001$ & 0.34 & 0.29 & 0.45 & $<0.001$ & 0.016 & 0.64 \\
\hline $10-20 \mathrm{~d}$ & 2.44 & 2.47 & 2.63 & 2.49 & $2.33^{\mathrm{a}}$ & $2.53^{\mathrm{b}}$ & $2.65^{b}$ & - & 0.32 & $<0.001$ & 0.35 & 0.092 & 0.18 & $<0.001$ & 0.18 & 0.37 \\
\hline $20-25 d$ & 1.11 & 1.14 & 1.22 & 1.14 & $1.08^{\mathrm{a}}$ & $1.24^{\mathrm{b}}$ & $1.13^{\mathrm{a}}$ & - & 0.22 & $<0.001$ & 0.64 & 0.24 & 0.26 & $<0.001$ & 0.32 & 0.17 \\
\hline $0-25 \mathrm{~d}$ & 5.22 & 5.28 & 5.62 & 5.31 & $4.99^{\mathrm{a}}$ & $5.45^{\mathrm{b}}$ & $5.63^{b}$ & - & 0.67 & $<0.001$ & 0.38 & 0.12 & 0.18 & $<0.001$ & 0.085 & 0.38 \\
\hline
\end{tabular}

$\overline{\mathrm{a}-\mathrm{c}}$ Parity order mean values in the same row with a different superscript differ, $\mathrm{P}<0.05 .{ }^{1} \mathrm{C}=$ control diet; Arg $=0.4 \%$ arginine dietary supplementation; Gln $=0.4 \%$ glutamine dietary supplementation; Arg+Gln $=0.4 \%$ arginine $+0.4 \%$ glutamine supplementation. ${ }^{2}$ covariates: number of kits at $10 \mathrm{~d}$ for $0-10 \mathrm{~d}$ milk production, number of kits at $20 \mathrm{~d}$ for 10-20 d milk production, number of kits at $25 \mathrm{~d}$ for $20-25 \mathrm{~d}$ and $0-25 \mathrm{~d}$ milk production. ${ }^{3}$ No significant differences $(\mathrm{P} \geq 0.48)$ were found when the interaction Arg $\times$ Gln $\times$ Parity was analyzed. 
Table 7. Effect of arginine and glutamine supplementation over time (parturition, AI and weaning) and parity order on body chemical composition and energy content of rabbit does.

\begin{tabular}{|c|c|c|c|c|c|c|c|c|c|c|c|c|c|c|c|c|c|}
\hline \multirow[b]{3}{*}{ Arginine, $\mathrm{g} / \mathrm{kg}$} & \multicolumn{4}{|c|}{ Diets } & \multicolumn{4}{|c|}{ Parity order } & \multirow[t]{4}{*}{ rsd } & \multicolumn{8}{|c|}{ P-value } \\
\hline & $\mathrm{C}$ & Arg & Gln & $\mathrm{Arg}+\mathrm{Gln}$ & 1 & 2 & 3 & 4 & & \multirow[t]{3}{*}{$\operatorname{Cov}^{2}$} & \multirow[t]{3}{*}{ Arg } & \multirow[t]{3}{*}{ Gln } & \multirow[t]{3}{*}{$\operatorname{Arg} \times \mathrm{Gln}$} & \multirow[t]{3}{*}{ Parity } & \multirow[t]{3}{*}{ Arg $\times$ Parity } & \multirow[t]{3}{*}{ Gln $\times$ Parity } & \multirow[t]{3}{*}{$\begin{array}{c}\operatorname{Arg} \times \\
\text { Gln } \times \text { Parity }\end{array}$} \\
\hline & 0 & 4 & 0 & 4 & & & & & & & & & & & & & \\
\hline Glutamine, $\mathrm{g} / \mathrm{kg}$ & 0 & 0 & 4 & 4 & & & & & & & & & & & & & \\
\hline Number of rabbit does & 14 & 14 & 15 & 15 & 58 & 58 & 56 & 56 & & & & & & & & & \\
\hline \multicolumn{18}{|l|}{ Parturition } \\
\hline Moisture, $\mathrm{g} / \mathrm{kg}$ & 610 & 610 & 610 & 617 & 612 & 613 & 609 & - & 22.3 & $<0.001$ & 0.40 & 0.44 & 0.45 & 0.47 & 0.20 & 0.52 & 0.59 \\
\hline Protein, $\mathrm{g} / \mathrm{kg}$ & 179 & 179 & 178 & 179 & $179^{\mathrm{b}}$ & $179^{\mathrm{b}}$ & $177^{\mathrm{a}}$ & - & 3.23 & $<0.001$ & 0.40 & 0.96 & 0.33 & 0.002 & 0.096 & 0.098 & 0.87 \\
\hline Fat, $\mathrm{g} / \mathrm{kg}$ & 146 & 146 & 146 & 138 & 142 & 142 & 147 & - & 23.3 & $<0.001$ & 0.39 & 0.48 & 0.51 & 0.37 & 0.14 & 0.52 & 0.69 \\
\hline Ash, $g / k g$ & 31.5 & 31.6 & 31.5 & 31.7 & 31.4 & 31.6 & 31.7 & - & 1.18 & 0.002 & 0.47 & 0.83 & 0.96 & 0.083 & 0.11 & 0.64 & 0.88 \\
\hline Energy, MJ/kg BW & 11.0 & 10.9 & 11.0 & 10.6 & 10.9 & 10.8 & 11.0 & - & 0.95 & $<0.001$ & 0.40 & 0.45 & 0.44 & 0.45 & 0.21 & 0.54 & 0.60 \\
\hline \multicolumn{18}{|c|}{ Artificial insemination $(11 \mathrm{~d})$} \\
\hline Moisture, $\mathrm{g} / \mathrm{kg}$ & 599 & 598 & 593 & 602 & $594^{\mathrm{ab}}$ & $585^{\mathrm{a}}$ & $604^{\mathrm{b}}$ & $610^{\mathrm{b}}$ & 28.2 & $<0.001$ & 0.50 & 0.87 & 0.40 & $<0.001$ & 0.69 & 0.88 & 0.16 \\
\hline Protein, $\mathrm{g} / \mathrm{kg}$ & 181 & 181 & 181 & 182 & $181^{\mathrm{ab}}$ & $183^{\mathrm{b}}$ & $181^{\mathrm{ab}}$ & $180^{\mathrm{a}}$ & 4.16 & 0.062 & 0.85 & 0.90 & 0.49 & 0.019 & 0.23 & 0.73 & 0.85 \\
\hline Fat, $\mathrm{g} / \mathrm{kg}$ & 152 & 154 & 158 & 149 & $154^{\mathrm{a}}$ & $165^{\mathrm{b}}$ & $149^{\mathrm{a}}$ & $145^{\mathrm{a}}$ & 26.8 & $<0.001$ & 0.50 & 0.96 & 0.39 & $<0.001$ & 0.65 & 0.92 & 0.15 \\
\hline Ash, g/kg & 31.3 & 31.2 & 31.2 & 31.4 & $31.1^{\mathrm{b}}$ & $30.7^{\mathrm{a}}$ & $31.4^{\mathrm{bc}}$ & $3.18^{\mathrm{c}}$ & 1.11 & $<0.001$ & 0.74 & 0.90 & 0.61 & $<0.001$ & 0.75 & 0.89 & 0.53 \\
\hline Energy, MJ/kg BW & 11.3 & 11.4 & 11.5 & 11.2 & $11.4^{\mathrm{ab}}$ & $11.8^{\mathrm{b}}$ & $11.1^{\mathrm{a}}$ & $11.0^{\mathrm{a}}$ & 1.11 & $<0.001$ & 0.52 & 0.93 & 0.39 & $<0.001$ & 0.62 & 0.86 & 0.11 \\
\hline \multicolumn{18}{|l|}{ Weaning $(25 \mathrm{~d})$} \\
\hline Moisture, $\mathrm{g} / \mathrm{kg}$ & 629 & 620 & 625 & 632 & $631^{\mathrm{b}}$ & $629^{b}$ & $618^{\mathrm{a}}$ & - & 28.9 & $<0.001$ & 0.90 & 0.57 & 0.24 & 0.007 & 0.54 & 0.65 & 0.046 \\
\hline Protein, g/kg & 179 & 178 & 178 & 179 & $180^{\mathrm{b}}$ & $178^{\mathrm{a}}$ & $178^{\mathrm{a}}$ & - & 2.69 & $<0.001$ & 0.75 & 0.44 & 0.31 & $<0.001$ & 0.26 & 0.26 & 0.89 \\
\hline Fat, $\mathrm{g} / \mathrm{kg}$ & 134 & 142 & 138 & 131 & $130^{\mathrm{a}}$ & $135^{\mathrm{ab}}$ & $143^{b}$ & - & 26.7 & $<0.001$ & 0.99 & 0.52 & 0.25 & 0.007 & 0.81 & 0.55 & 0.13 \\
\hline Ash, $\mathrm{g} / \mathrm{kg}$ & 30.8 & 30.6 & 30.8 & 30.9 & 30.9 & 30.6 & 30.8 & - & 1.00 & $<0.001$ & 0.96 & 0.51 & 0.55 & 0.25 & 0.55 & 0.13 & 0.97 \\
\hline Energy, MJ/kg BW & 10.3 & 10.7 & 10.5 & 10.2 & $10.2^{\mathrm{a}}$ & $10.3^{\mathrm{a}}$ & $10.7^{\mathrm{b}}$ & - & 1.17 & $<0.001$ & 0.94 & 0.53 & 0.25 & 0.007 & 0.64 & 0.59 & 0.068 \\
\hline
\end{tabular}

${ }^{1} \mathrm{C}=$ control diet; $\mathrm{Arg}=0.4 \%$ arginine dietary supplementation; Gln = 0.4\% glutamine dietary supplementation; Arg+Gln = $0.4 \%$ arginine $+0.4 \%$ glutamine supplementation .

${ }^{2}$ Initial body weight. Initial proportion of moisture, protein, fat, ash and energy were not significant as covariates. ${ }^{\mathrm{a}-\mathrm{c}}$ mean values in the same row with a different superscript differ, $\mathrm{P}<0.05$. 


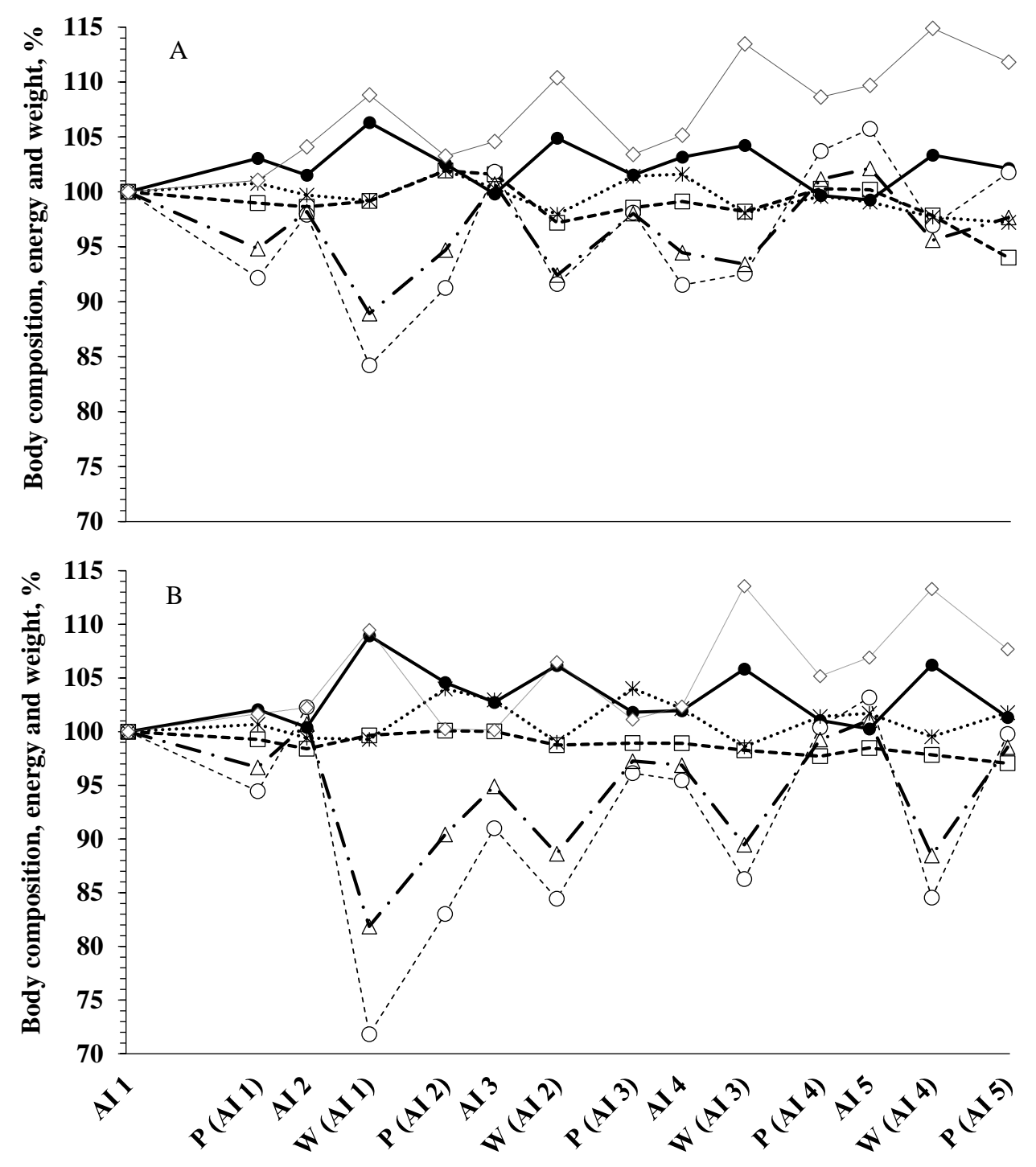

Productive/reproductive events along time

Figure 1. Evolution of body composition, energy and weight (Moisture $\bullet$, protein $\square$, fat $\circ$, ash *, energy $\Delta$, and body weight $\diamond$ ) over time (artificial insemination -AI-, parturition $-\mathrm{P}$ - and weaning $-\mathrm{W}-)$ of all rabbit does considered for productive traits $(\mathrm{n}=58$. Figure. $1 \mathrm{~A})$ or only those that had five consecutive parturitions $(n=14$. Figure $1 \mathrm{~B})$. Values obtained at first artificial insemination (AI 1) were considered as 100 (Fig. $2 \mathrm{~A}-\mathrm{g} / \mathrm{kg}$ BW-: Moisture: $594 \pm 27$, protein: $181 \pm 3$, fat: $155 \pm 29$; ash: $31 \pm 1 \%$; energy: $11.5 \pm$ $1.2 \mathrm{MJ} / \mathrm{kg} \mathrm{BW}$; body weight: $3.9 \pm 0.2 \mathrm{~kg}$. Fig. $2 \mathrm{~B}: 614 \pm 32$, protein: $182 \pm 1$, fat: 135 \pm 32 ; ash: $32 \pm 0.9$; energy: $10.6 \pm 1.38 \mathrm{MJ} / \mathrm{kg} \mathrm{BW}$; body weight: $3.8 \pm 0.1 \mathrm{~kg}$ ) and the values obtained later were expressed as percentage of the value obtained at AI 1 . $\mathrm{P}_{\text {Time }}<$ 0.001 in both figures.

AI 1, AI 2, AI 3 and AI 4: $1^{\text {st }}, 2^{\text {nd, }} 3^{\text {rd }}$ and $4^{\text {th }}$ artificial insemination, respectively. P (IA 1), P (IA 2), P (IA 3), P (IA 4) and P (IA 5): Parturition corresponding to IA 1, AI 2, AI 3 and AI 4, respectively. W (IA 1), W (IA 2), W (IA 3) and W (IA 4): Weaning corresponding to IA 1, AI 2, AI 3 and AI 4, respectively. 


\subsection{Effect of pre- and post-weaning dietary supplementation with arginine and glutamine in growing rabbits.}

\subsubsection{Introduction.}

Glutamine plays a fundamental role in the gastrointestinal integrity and functionality ( $\mathrm{Wu}, 1998)$. It is the major energy source for enterocytes (Wu, 1998), is involved in protein synthesis and inhibits proteolysis in small intestinal cells (Coeffier et al., 2003). In growing rabbits, glutamine supplementation (from 0.5 to $1 \%$ of diet) reduces the mortality caused by ERE without other effects on growth performances (Baylos et al., 2008; Chamorro et al., 2010). However, the optimal dietary level is not clear yet. Whereas Chamorro et al. (2010) reported lower mortality with $1 \%$ of glutamine, Baylos et al. (2008) showed this effect with $0.5 \%$ of glutamine supplementation and observed not effect were with $1 \%$. Dietary supplementation with $1 \%$ of glutamine also modified intestinal microbiota, decreasing the frequency of detention of potential pathogenic bacteria as $\mathrm{C}$. perfringens and Helicobacter spp. and improved the mucosal barrier mechanism decreasing the presence of Eimeria at jejunal level (Chamorro et al., 2010). Nevertheless, in contrast with studies in early weaned piglets, where supplementation with $1 \%$ of glutamine prevents jejunal villi atrophy, in rabbits, glutamine supplementation had not effect on villous length or some indicators of enterocyte functionality ( $\mathrm{N}$-amino peptidase activity).

Arginine increases cell size and protein synthesis (Naomoto et al., 2005) and is the precursor for the nitric oxide (NO), improving the intestinal health (Tapiero et al., 2002). In swine production, it has been demonstrated that dietary supplementation from 0.4 to 1 $\%$ of arginine increased litter size (Ramaekers et al., 2006; Li, 2011). This positive effect was also observed in rabbit does supplemented with $0.4 \%$ of arginine (Chapter 3.1 ). However, when supplementation increased up to $1.23 \%$, negative or no effects were found in litter size and weight (Greiner et al., 2012; Zier-Rush et al., 2012). In young pigs (from 7 to $21 \mathrm{~d}$ of age), dietary supplementation with 0.2 and $0.4 \%$ of arginine improved growth performance. For growing rabbits, arginine is an indispensable amino acid (Gaman and Fisher., 1970; Adamson and fisher., 1976) being $1.0 \%$ (on DM basis) the best dose to optimize the growth rate (Mc Ward et al., 1967; Colin, 1975; Baker and Boebel, 1981). The extra supplementation with $0.4 \%$ of arginine in growing rabbits did not improve growth rates compared with respect to the control diet (Chamorro et al., 
2010). The effect of arginine and glutamine supplementation on nitrogen retention has been poorly studied in rabbits. In this way, Colin (1975) observed that in vivo nitrogen retention coefficient improved up to $1 \%$ (on DM basis) of arginine supplementation.

The aim of this work was to study the effect of supplementation with arginine and glutamine and its interaction on growth performance, apparent ileal and faecal digestibility, in vivo chemical composition (body and carcass) and nitrogen and energy body and carcass retention efficiency and excretion in growing rabbits.

\subsubsection{Materials and methods.}

\subsubsection{Animals and housing.}

Crossbred hybrid (New Zealand White $\times$ Californian, $\mathrm{V} \times \mathrm{R}$ from UPV, Valencia, Spain) rabbits were used. Rabbits were housed in flack-deck cages (650 mm x $250 \mathrm{~mm}$ x $330 \mathrm{~mm}$ ) in groups of 2-3 rabbits/cage throughout the trial (3 consecutive fattening cycles). Rabbits were fed with the experimental diets described in Chapter 3.1. Housing conditions were controlled during the whole experimental period. The farm temperature was maintained between 18 and $24^{\circ} \mathrm{C}$ with $12 \mathrm{~h}$ of light and $12 \mathrm{~h}$ of darkness. All the experimental procedures used were approved by the Animal Ethics Committee of the Universidad Politécnica de Madrid, and were in compliance with the Spanish guidelines for care and use of animals in research (BOE, 2013).

\subsubsection{Growth performance and mortality trial.}

Growth performance and mortality were studied in three consecutive fattening periods using 1223 rabbits. Litters used throughout the study came from rabbit does studied in the Chapter 3.1. In the first trial (T1), litters came from primiparous does resulting pregnant in the first artificial insemination, while in trials 2 (T2) and 3 (T3) came from rabbits does pregnant in the second and third artificial insemination respectively. In each trial, rabbits were weaned at $25 \mathrm{~d}$ of age and controlled until $55 \mathrm{~d}$ of age. Rabbits had ad libitum access to feed and water, and each litter received the same diet as its mother. Feed intake, body weight gain and feed efficiency were measured $10 \mathrm{~d}$ after weaning and at the end of the experiment (day 30), whereas mortality was recorded daily. 
In T1, 491 rabbits weighting $392 \pm 93.3 \mathrm{~g}$ (mean \pm standard deviation), from 62 litters were divided in two groups (T1a and T1b) and housed in collective cages (2-3 rabbits/cage). The first one (T1a) included 312 rabbits weighting $372 \pm 82.9 \mathrm{~g}$ from 36 litters and they were housed in 116 collective cages (from 25 to 33 cages/diet) and T1b consisted in 179 rabbits from 26 litters (average BW of $423 \pm 101 \mathrm{~g}$ ) and housed in 74 collective cages (from 13 to 25 cages/diet). In T2 were used 454 rabbits from 49 litters (average BW $386 \pm 76.4 \mathrm{~g}$ ) allocated in 170 collective cages (from 31 to 46 cages/treatment), and T3 included 278 rabbits from 31 litters (average BW $432 \pm 70.2 \mathrm{~g}$ ) housed in 103 collective cages (from 20 to 32 cages/diet).

In T1a, animals were fed with the experimental diets during the whole fattening (Tables 1 and 2), whereas rabbits from T1b, T2 and T3 were fed with the experimental diets from day 25 to 35 , and with the $\mathrm{C}$ diet from 35 to $55 \mathrm{~d}$.

\subsubsection{Apparent ileal digestibility.}

Ninety-six rabbits (24/diet), weighting $405 \pm 59.9 \mathrm{~g}$ (mean \pm standard deviation) from 9 litters (10-11 rabbits/litter) from rabbit does pregnant in the third artificial insemination, were weaned at $25 \mathrm{~d}$ of age and blocked by litter and assigned at random to the experimental diets and housed individually to determine apparent ileal digestibility of DM, $\mathrm{N}$ and amino-acids after of 10 days adaptation period. All the animals were slaughtered by $\mathrm{CO}_{2}$ inhalation between 19:00 and 21:00 hours to minimize the influence of cecotrophy at $35 \mathrm{~d}$ of age. The last $20 \mathrm{~cm}$ of ileum were excised and ileal contents were removed, frozen, freeze-dried, and the ground. Due to the small quantity of sample, they were pooled in groups of 2-3 animals resulting 7 pools/treatment to analyze ytterbium and $\mathrm{N}$, and calculated ileal digestibility of DM, starch and N according to Gómez-Conde et al. (2007). Once done these determinations, a fixed amount of ileal digesta of each treatment was mixed in one pool per treatment to analyze amino-acids to determine their apparent ileal digestibility.

\subsubsection{Apparent faecal digestibility.}

Forty-four animals (11/diet) from apparent ileal digestibility were chosen at random, blocked by litter and housed individually in metabolism cages to determine apparent faecal digestibility. Rabbits weighed $415 \pm 53.4 \mathrm{~g}$ at weaning (mean \pm standard deviation). Apparent faecal digestibility of DM, N, gross energy and aNDF were determine. Rabbits had ad libitum access to feed and water. Following a 7 day adaptation 
period, feed intake and total fecal output were recorder for each rabbit over 3 day collection period from 32 to $35 \mathrm{~d}$ of age according to Gómez-Conde et al. (2007). Faeces produced daily were collected in labeled polyethylene bags, stored at $-20^{\circ} \mathrm{C}$, dry at $80^{\circ} \mathrm{C}$ during 48 hours and ground with a $1 \mathrm{~mm}$ screen for analysis.

\subsubsection{Carcass chemical composition trial and calculations of energy and nitrogen efficiency.}

One animal per cage, from 104 collectively cages (26/diet) belonging to T1a, was chosen at random to determine their corporal and carcass condition at weaning ( $25 \mathrm{~d}$ of age) and at $55 \mathrm{~d}$ of age. At weaning, rabbits weighed $398 \pm 66.4 \mathrm{~g}$. Carcass chemical composition and energy content was estimated using the bioelectrical impedance analysis (BIA) (Saiz et al., 2013a, b; Saiz et al., 2017). Measurements of resistance and reactance were taken in rabbits with a body composition analyzer (Model Quantum II, RJL Systems, Detroit, MI, USA) at 25 and $55 \mathrm{~d}$ of age. Multiple regression equations according to Saiz et al. (2013a, b and 2017) were used to estimate water, protein, ash, fat and energy proportions both in in the body and in the carcass.

Estimated values for the carcass nitrogen and energy content were used to calculate the nitrogen and energy retention in the carcass (NR carcass and ER carcass, respectively) between 25 and $55 \mathrm{~d}$ of age. Values were expressed per kg BW0.75 and day. Moreover, nitrogen and energy intake ( $\mathrm{Ni}$ and GEi, respectively) and digestible $\mathrm{N}$ and digestible energy intake (DNi and DEi, respectively) were recorded to calculate the overall $\mathrm{N}$ and GE carcass retention efficiency was calculated as: NR carcass/DNi and ER carcass/DEi, both expressed as \%.

Total $\mathrm{N}$ and GE excretion as skin and viscera, faeces or heat production and urine were calculated as follows:

$\mathrm{N}$ excreted as skin and viscera $(\mathrm{g} / \mathrm{kg} \mathrm{BW} 0.75$ and day $)=(\mathrm{g} N \mathrm{~N}$ in vivo $-\mathrm{g} \mathrm{NR}$ carcass)/ kg BW0.75 and day.

$\mathrm{N}$ excreted as faeces $(\mathrm{g} / \mathrm{kg} \mathrm{BW} 0.75$ and day $)=(\mathrm{Ni}-\mathrm{DNi}) / \mathrm{kg}$ BW0.75 and day.

$\mathrm{N}$ excreted as urine $(\mathrm{g} / \mathrm{kg} \mathrm{BW} 0.75$ and day $)=(\mathrm{DNi}-\mathrm{NR}$ in vivo $) / \mathrm{kg} \mathrm{BW} 0.75$ and day.

Energy excreted as skin and viscera $(\mathrm{MJ} / \mathrm{kg} \mathrm{BW0.75}$ and day $)=(\mathrm{MJ}$ ER in vivo MJ ER carcass)/ kg BW0.75 and day.

Energy excreted as faeces $(\mathrm{MJ} / \mathrm{kg}$ BW0.75 and day $)=(\mathrm{GEi}-\mathrm{DEi}) / \mathrm{kg}$ BW0.75 and day. 
Energy excreted as urine and heat production $(\mathrm{MJ} / \mathrm{kg} \mathrm{BW} 0.75$ and day $)=(\mathrm{DEi}-$ $\mathrm{RE}$ in vivo)/ $\mathrm{kg}$ BW0.75 and day.

\subsubsection{Chemical analysis.}

Procedures of the AOAC (2000) were used to determine the dietary concentrations of DM (934.01), ash (942.05), nitrogen (954.01), ether extract (920.39), starch (amyloglucosidase- $\alpha$-amylase method; method 996.11) starch (amyloglucosidase- $\alpha$ amylase method; method 996.11) and total dietary fibre (985.29). Dietary aNDFom, ADFom and lignin (sa) were determined sequentially using the filter bag system (Ankom Technology, New York, NY). Dietary aNDFom was determined according to Mertens et al. (2002) using a thermo-stable amylase without any sodium sulphite added. Dietary ADFom and ADL were analyzed according to Goering and Van Soest (1970), respectively. The soluble fiber was calculated as the difference between total dietary fibre and aNDFom (both corrected for ash and protein). Gross energy was measured by adiabatic bomb calorimeter (model 356, Parr Instrument Company, Moline, IL). Diets were analyzed in triplicate, and ileal digesta and faeces were analyzed in duplicate. Amino acids were determined after acid hydrolysis using a Beckman System 6300HPA AA analyzer (Fullerton, CA). Samples were hydrolyzed in $25 \mathrm{~mL}$ of $\mathrm{HCl} 6 \mathrm{~N}$ with $10 \mathrm{~g} / \mathrm{L}$ of added phenol for $24 \mathrm{~h}$ at $120^{\circ} \mathrm{C}$. For the determination of methionine and cystine, samples were oxidized with performic acid at $0^{\circ} \mathrm{C}$ for $16 \mathrm{~h}$ and then neutralized with $0.5 \mathrm{~g}$ of sodium meta-bisulphite before analysis. During acid hydrolysis, tryptophan was destroyed and was not determined. Besides, ytterbium content of diets and ileal digesta were assessed by atomic absorption spectrometry (Smith Hieftje 22, Thermo Jarrel Ash, MA) (García et al., 1999).

\subsubsection{Statistical analysis.}

Growth performance of T1a and T1b was analyzed as a factorial arrangement using a mixed model (Littell et al., 1996). It included the level of arginine, glutamine, the trial and their interactions as a fixed effects, the rabbit was a random effect and the weaning weight was incleded as a linear covariate. A linear model was used for growth performance of T1b, T2 and T3, faecal digestibility, in vivo chemical composition and energy and nitrogen balances (Mixed procedure of SAS). The main factors studied were arginine and glutamine supplementation and their interactions. Weaning weight was used as a covariate for growth traits. Weaning weight and the in vivo composition (protein, fat 
moisture, ash) and energy content at $25 \mathrm{~d}$ of age were used as covariates for in vivo body and carcass chemical composition. Nitrogen and energy retained in the body and in the carcass were included as covariates for in vivo and carcass nitrogen and energy efficiency, respectively. Ileal digestibility was analyzed as a completely randomized design with type of diet (C, Gln and Arg+Gln) as main effect, by using the GLM procedure of SAS. Mortality was analyzed using a logistic regression (GENMOD procedure of SAS considering a binomial distribution) including arginine and glutamine level and their interactions in the model, and the results were transformed from the logit scale. All data are presented as least-squares means. When interactions were significant $(\mathrm{P}<0.05)$ comparisons among all the treatment means were made using a t-test.

\subsubsection{Results.}

In the whole fattening period ( 25 to $55 \mathrm{~d}$ of age), mortality, was on average $37.4 \%$ for T1a (Figure 1a), 33.5\% for T1b (Figure 1b) and 38.1\% for T1b, T2 and T3 trials (Figure 2), and half of the mortality was observed on average at 42 (T1a), 36 (T1b) and 39 (T1b, T2 and T3) d of age.

From 25 to $35 \mathrm{~d}$ of age, there was not differences in mortality among treatments ( $\mathrm{P}$ $>0.05$ ). From 35 to $55 \mathrm{~d}$ of age, in T1a (where rabbits were fed with experimental diets), mortality was not affected by the treatments and it was on average $36.7 \%(P=0.92)$, whereas in $\mathrm{T} 1 \mathrm{~b}$ (where rabbits were fed with the $\mathrm{C}$ diet), rabbits fed in the first period with Gln supplementation tended to report lower mortality than those unsupplemented (20.9 vs $35.0 \%$; $\mathrm{P}=0.053$ ). However, these differences was not observed in $\mathrm{T} 1 \mathrm{~b}, \mathrm{~T} 2$ and $\mathrm{T} 3$ trials that averaged $33.8 \%(\mathrm{P}=0.14)$. Mortality in the whole experiment of trial $\mathrm{T} 1 \mathrm{~b}$ was lower in rabbits supplemented with glutamine in the first period than those unsupplemented (41.3 vs. 25.6; P = 0.042). In T1b, T2 and T3 trials mortality, tended to decrease with Gln supplementation (35.4 vs. $40.7 \%$; $\mathrm{P}=0.10)$.

In tables 1 and 2 are showed the growth performance obtained only from cages with no mortality. From 25 to $35 \mathrm{~d}$ of age, when all the animals were fed with experimental diets there were no difference in growth traits among treatments. An averaged $34.0 \mathrm{~g} / \mathrm{d}$, $46.9 \mathrm{~g} / \mathrm{d}, 0.723$ and $742 \mathrm{~g}$ respectively for weight gain, feed intake, feed efficiency and body weight at $35 \mathrm{~d}(\mathrm{P} \geq 0.10)$. In the second period ( 35 to $55 \mathrm{~d}$ of age), animals fed with the supplemented diets reported the same values than those that received the $\mathrm{C} \operatorname{diet}(\mathrm{P}=$ 0.65). In this way, in the whole period, treatments did not affect the weight gain, feed 
intake, feed efficiency and final body weight, that averaged $42.2 \mathrm{~g}, 78.6 \mathrm{~g}, 0.537$ and 1849 g respectively.

Rabbits from group T1a had a lower body weight at weaning that rabbits from group T1b (381 vs. $426 \mathrm{~g}, \mathrm{P}=0.032$ ), but in the first period ( 25 to $35 \mathrm{~d}$ of age) showed a higher weight gain and feed intake (36.5 vs. $31.6 \mathrm{~g} / \mathrm{d}$ and 49.9 vs. $44.0 \mathrm{~g} / \mathrm{d}$, respectively; $\mathrm{P} \leq$ 0.042), although both groups reported a similar feed efficiency $(\mathrm{P}=0.28)$. At $35 \mathrm{~d}$ of age animals from T1a had a higher body weight than those of the T1b (766 vs. $718 \mathrm{~g} ; \mathrm{P}=$ 0.029). From 35 to $55 \mathrm{~d}$ of age, T1b animals (all fed with $\mathrm{C}$ diet), increased its weight gain by $12 \%(\mathrm{P}<0.001)$, feed intake by $8 \%(\mathrm{P}=0.006)$ and feed efficiency by $7 \%(\mathrm{P}=$ 0.008 ) respect to those of $\mathrm{T} 1 \mathrm{a}$, reaching a higher final body weight (1894 vs. 1803; $\mathrm{P}=$ $0.039)$.

Rabbits coming from rabbit does fed with Arg or Gln diets had a higher body weight at weaning by 9 and 5\% respectively, than those from litters of rabbit does fed with $\mathrm{C}$ and Arg+Gln diets in T1b, T2 and T3 (P = 0.037; Table 2). However, post-weaning dietary treatments did not affect weight gain, feed intake, feed efficiency and final body weight during the whole fattening and were on average $45.5 \mathrm{~g} / \mathrm{d}, 89.4 \mathrm{~g} / \mathrm{d}, 0.511$ and $1838 \mathrm{~g}$ respectively.

Dietary supplementation with Gln or with Arg+Gln did not affect DM and nitrogen ileal digestibility, which were on average 43.1 and $69.5 \%$ respectively $(\mathrm{P} \geq 0.64$; Table 3). Animals fed with $\mathrm{Arg}+\mathrm{Gln}$ diets increased by $7 \%$ arginine $(\mathrm{P}<0.001)$ and by $4 \%$ methionine $(\mathrm{P}=0.032)$ ileal digestibility and tended to increase glycine ileal digestibility $(\mathrm{P}=0.082)$ compared to $\mathrm{C}$ diet, showing an intermediate value animals fed with Gln diet. Moreover Gln and Arg+Gln diets increased glutamic acid (87.9 vs. 85.4\%; P = 0.008) and tended to increase leucine and lysine ileal digestibility respect to $\mathrm{C} \operatorname{diet}(\mathrm{P} \leq 0.096)$.

Feed intake during the faecal digestibility trial did not differ among treatments $(80.5$ $\mathrm{g} / \mathrm{d}$ on average; $\mathrm{P} \geq 0.30$ ). Dry matter and nitrogen faecal digestibility increased by $6 \%$ $(\mathrm{P}=0.005$; Table 4) and 5\% $(\mathrm{P}=0.008)$ respectively, in animals fed with Arg, Gln or Arg+Gln diets with respect to those fed $\mathrm{C}$ diet, whereas, energy faecal digestibility increased by $6 \%(\mathrm{P}=0.003)$ in animals supplemented with arginine and glutamine respect to rabbits unsupplemented, showing the diet Arg+Gln an intermediate value. Moreover, glutamine supplementation increased faecal digestibility of neutral detergent fibre $(32.7$ vs. $25.2 \% ; \mathrm{P}<0.001)$ respect to unsupplemented diets. 
Animals chosen for carcass chemical composition showed at weaning, a trend to be higher when came from litters whose rabbit does were supplemented with Gln respect to unsupplemented litters $(\mathrm{P}=0.086$; Table 5). However, final body weight at $55 \mathrm{~d}$ of age, were similar for all traits (1883 $\mathrm{g}$ on average; $\mathrm{P} \geq 0.25)$. Treatments did not affect to carcass chemical composition at weaning $(25 \mathrm{~d})$ and at $55 \mathrm{~d}$ of age $(\mathrm{P} \geq 0.12)$. Nevertheless, at weaning, Gln supplementation tended to increase carcass moisture compared to unsupplemented rabbits $(\mathrm{P}=0.099)$.

The feed intake used was the average obtained per treatment and trial (T1a and T1b) from 25 to $55 \mathrm{~d}$ of age.

Total and digestible nitrogen intake increased by 10 and 8\%, respectively with Arg supplementation $(\mathrm{P} \leq 0.002)$, whereas the nitrogen retention in the carcass did not differ among treatments. Moreover, Arg supplementation increased total and digestible energy intake by 7 and $8 \%$ respectively $(P \leq 0.002)$. According by Arg supplementation decreased by 8 and $7 \%$ ( $P<0.001)$ the retention efficiency of digestible nitrogen and energy, respectively. It was associated with an increase of nitrogen in urine excretion (by $23 \% ; \mathrm{P}=0.030)$ and with a tendency to increase nitrogen losses in skin and viscera $(\mathrm{P}=$ 0.098) with Arg supplementation. Also, energy losses in faeces $(P=0.060)$ and in urine + heat production $(\mathrm{P}=0.003)$ increased with Arg supplementation.

Amino acid supplementation decreased faecal nitrogen excretion (by 20\%; $\mathrm{P}<$ 0.001 ) and Gln supplementation decreased faecal energy excretion (by $8.40 \% ; \mathrm{P}<0.001$ ). Rabbits received $\mathrm{C}$ and Arg+Gln diets tend to decrease skin and viscera energy losses respect to those fed Gln and Arg diets, and rabbits fed with Gln diet decreased faecal energy excretion by $20 \%$ with respect to those fed C and Arg + Gln diets $(\mathrm{P}<0.001)$.

\subsubsection{Discussion.}

Mortality was related to ERE and appeared in T1a around 10 days after weaning as was observed by Romero et al. (2009). Dead rabbits exhibited macroscopic lesion characteristic of ERE (Pérez de Rozas et al., 2005; Licois et al., 2005). When animals were supplemented with amino acid during the whole experiment, there was not difference among treatments. However, when rabbits were supplemented with glutamine during the first 10 days of fattening, mortality was reduced in the whole of the fattening period. This is in agreement with previous results obtained with a 0.5 and $1 \%$ of glutamine supplementation (Baylos et al., 2008; Chamorro et al., 2010). 
As it was expected, supplementation with Arg, Gln or Arg+Gln did not affect growth performance because the amino acid levels are enough to meet rabbits postweaning requirements, which is in agreement with previous results (Baylos et al., 2008; Chamorro et al., 2010). However, and regardless the treatments, rabbits had a feed intake around 30-40 \% lower than that would correspond to their age and genetic type, being this effect more acute from 25 to $35 \mathrm{~d}$ of age, which led to a reduction in the weight gain.

The higher arginine and glutamic acid ileal digestibility obtained in rabbits fed with Gln and Arg+Gln suggest that supplemented Arg and Gln was totally digested in the small intestine. Moreover, amino acid supplementation increased faecal digestibility of DM, nitrogen and energy and tended to increase faecal digestibility of FND. This could be related with changes in the caecal microflora as was reported by Chamorro et al. (2007).

The nitrogen and energy retained in the carcass were not modified by treatments, because the diets were adequately balanced according to standard recommendations (De Blas and Mateos., 2010) and allowed rabbits to meet their nutrients requirements. However, rabbits showed lower values of nitrogen and gross energy intake than those obtained in the Chapter 4.2 because feed intake in his study was similar to those obtained with restrictions between 85 and 70\% (Bergaoui et al., 2008; Gidenne et al., 2009). For this reason, rabbits had a lower digestible nitrogen and energy intake, increasing the nitrogen and energy retained in carcass and as a consequence the nitrogen retention efficiency compared to results obtained in Chapter 4.2. In addition, nitrogen and energy losses expressed as skin and viscera, faeces and urine were also lower than reported in chapter 4.2. Rabbits fed with Arg diet, had higher nitrogen and gross energy digestible intake than those not supplemented, which together with the lack of effect on the nitrogen and energy retained in the carcass led to an improvement of the efficiency of digestible nitrogen and energy retained the in carcass. In this sense, the proportion of nitrogen retention in the body was higher with a dietary supplementation of $1 \% \operatorname{Arg}$ (Colin 1975). Nevertheless, in this study, $\mathrm{C}$ diet contained $1.13 \%$ of Arg which might explain why the nitrogen retained in the carcass did not improve with Arg supplementation. Moreover, urinary nitrogen losses and energy losses in urine + heat production showed lower values than those obtained in chapter 4.2 and Arg supplementation increased these nitrogen and energy losses. In conclusion, $0.4 \%$ of glutamine supplementation to post-weaned rabbits during the first days decreased fattening mortality. Amino acid supplementation did not 
affect to growth performance and supplementation with $0.4 \%$ of Arg reduced the nitrogen and energy retention efficiency. 
Table1. Effect of arginine and glutamine supplementation on finishing performance in rabbits fed with experimental diets during all the fattening (Trial 1a; T1a) vs. rabbits fed with experimental treatments from 25 to $35 \mathrm{~d}$ of age and with the control diet from 35 to $55 \mathrm{~d}$ of age (Trial $1 \mathrm{~b}$; T1b).

\begin{tabular}{|c|c|c|c|c|c|c|c|c|c|c|c|c|c|c|c|c|}
\hline & \multicolumn{4}{|c|}{ Diets $^{1}$} & \multicolumn{2}{|c|}{ Trial } & \multicolumn{5}{|c|}{ SEM } & \multicolumn{5}{|c|}{ P-value $^{4}$} \\
\hline & $\mathrm{C}$ & Arg & & & $1 \mathrm{a}$ & $1 b$ & \multirow[t]{2}{*}{ Arg and Gln } & \multirow[t]{2}{*}{ Arg $\times$ Gln } & Trial & \multirow[t]{2}{*}{$\begin{array}{c}\text { Arg } \times \text { Trial } \\
\text { and Gln×Trial } \\
\end{array}$} & $\begin{array}{c}\text { ArgxGln } \\
\times \text { Trial }\end{array}$ & \multirow[t]{2}{*}{$\operatorname{Cov}^{3}$} & \multirow[t]{2}{*}{ Arg } & \multirow[t]{2}{*}{ Gln } & \multirow[t]{2}{*}{$\operatorname{Arg} \times \mathrm{Gln}$} & Trial \\
\hline Arginine & 0 & 0.4 & 0 & 0.4 & & & & & & & & & & & & \\
\hline Glutamine & 0 & 0 & 0.4 & 0.4 & & & & & & & & & & & & \\
\hline $\mathrm{N}^{2}$ & 13 & 15 & 16 & 20 & 34 & 30 & & & & & & & & & & \\
\hline \multicolumn{17}{|l|}{25 to $35 \mathrm{~d}$ of age } \\
\hline Body weight $25 \mathrm{~d}$ & 381 & 407 & 422 & 404 & 381 & 426 & 14.5 & 20.5 & 14.5 & 20.4 & 28.8 & - & 0.84 & 0.37 & 0.29 & 0.032 \\
\hline Weight gain, $\mathrm{g} / \mathrm{d}$ & 33.6 & 34.6 & 32.8 & 35.1 & 36.5 & 31.6 & 1.47 & 2.09 & 1.51 & 2.10 & 2.96 & 0.068 & 0.43 & 0.93 & 0.76 & 0.030 \\
\hline Feed intake, g/d & 47.6 & 48.3 & 45.4 & 46.4 & 49.9 & 44.0 & 1.95 & 2.77 & 2.00 & 2.78 & 3.92 & 0.16 & 0.76 & 0.47 & 0.96 & 0.042 \\
\hline Feed efficiency, g/g & 0.710 & 0.711 & 0.717 & 0.756 & 0.735 & 0.712 & 0.015 & 0.021 & 0.015 & 0.021 & 0.030 & 0.29 & 0.33 & 0.22 & 0.38 & 0.28 \\
\hline \multicolumn{17}{|c|}{35 to $55 \mathrm{~d}$ of age } \\
\hline Body weight 35d & 738 & 748 & 729 & 752 & 766 & 718 & 14.7 & 20.9 & 15.0 & 21.0 & 29.6 & $<0.001$ & 0.43 & 0.93 & 0.75 & 0.029 \\
\hline Weight gain, g/d & 54.8 & 56.0 & 55.5 & 54.2 & 51.6 & 58.7 & 1.23 & 1.74 & 1.26 & 1.75 & 2.47 & 0.56 & 0.97 & 0.76 & 0.48 & $<0.001$ \\
\hline Feed intake, g/d & 120 & 121 & 128 & 120 & 117 & 127 & 3.37 & 4.78 & 3.45 & 4.80 & 6.77 & 0.12 & 0.50 & 0.53 & 0.33 & 0.006 \\
\hline Feed efficiency, g/g & 0.470 & 0.462 & 0.441 & 0.452 & 0.438 & 0.474 & 0.009 & 0.012 & 0.009 & 0.013 & 0.018 & 0.10 & 0.89 & 0.13 & 0.46 & 0.008 \\
\hline \multicolumn{17}{|l|}{25 to $55 \mathrm{~d}$ of age } \\
\hline Body weight 55d & 1834 & 1865 & 1855 & 1842 & 1803 & 1894 & 29.3 & 41.5 & 30.0 & 41.7 & 58.8 & $<0.001$ & 0.82 & 0.98 & 0.60 & 0.039 \\
\hline Weight gain, g/d & 42.3 & 43.6 & 39.6 & 43.3 & 42.5 & 41.8 & 1.25 & 1.77 & 1.27 & 1.78 & 2.50 & 0.015 & 0.17 & 0.39 & 0.49 & 0.71 \\
\hline Feed intake, g/d & 78.4 & 81.2 & 75.0 & 80.0 & 80.3 & 76.9 & 2.23 & 3.16 & 2.28 & 3.18 & 4.48 & 0.004 & 0.22 & 0.47 & 0.73 & 0.30 \\
\hline Feed efficiency, g/g & 0.541 & 0.538 & 0.526 & 0.543 & 0.531 & 0.543 & 0.007 & 0.009 & 0.007 & 0.010 & 0.013 & 0.29 & 0.45 & 0.65 & 0.31 & 0.21 \\
\hline
\end{tabular}

${ }^{1} \mathrm{C}=$ control diet; $\mathrm{Arg}=0.4 \%$ arginine dietary supplementation; Gln = 0.4\% glutamine dietary supplementation; Arg+Gln = 0.4\% arginine $+0.4 \%$ glutamine supplementation. ${ }^{2} \mathrm{~N}=$ Number of cages. ${ }^{3}$ Average body weight per cage at $25 \mathrm{~d} .{ }^{4}$ An interaction Arg $\times$ trial was found in feed intake from 35 to $55 \mathrm{~d}$ of age $(\mathrm{P}=0.036)$ and a trend in feed efficiency from 25 to $35 \mathrm{~d}$ of age $(\mathrm{P}=0.068)$, in all the other cases $\mathrm{P} \geq 0.14$. No significant differences were found when the interaction Gln $\times$ Trial and Arg $\times$ Gln $\times$ Trial was analyzed $(\mathrm{P} \geq 0.13)$. 
Table 2. Effect of arginine and glutamine supplementation on finishing performance in rabbits fed with experimental treatments from 25 to $35 \mathrm{~d}$ of age and with the control diet from 35 to $55 \mathrm{~d}$ of age of trial $1 \mathrm{~b}(\mathrm{~T} 1 \mathrm{~b})$, trial 2 (T2) and trial 3 (T3).

\begin{tabular}{|c|c|c|c|c|c|c|c|c|c|c|}
\hline & \multicolumn{4}{|c|}{ Diets $^{1}$} & \multicolumn{2}{|c|}{ SEM } & \multicolumn{4}{|c|}{$\mathrm{P}$-value } \\
\hline & $\mathrm{C}$ & Arg & Gln & Arg+Gln & Arg and & Arg $\times$ Gln & $\operatorname{Cov}^{3}$ & Arg & Gln & Arg $\times$ Gln \\
\hline Arginine & 0 & 0.4 & 0 & 0.4 & & & & & & \\
\hline Glutamine & 0 & 0 & 0.4 & 0.4 & & & & & & \\
\hline $\mathrm{N}^{2}$ & 29 & 25 & 27 & 32 & & & & & & \\
\hline \multicolumn{11}{|l|}{25 to $35 \mathrm{~d}$ of age } \\
\hline Body weight $25 \mathrm{~d}$ & 403 & 443 & 426 & 403 & 10.6 & 14.9 & - & 0.56 & 0.60 & 0.037 \\
\hline Weight gain, g/d & 29.1 & 29.8 & 31.1 & 29.4 & 1.06 & 1.51 & 0.28 & 0.74 & 0.60 & 0.41 \\
\hline Feed intake, g/d & 41.7 & 45.4 & 45.1 & 42.7 & 1.32 & 1.87 & 0.65 & 0.73 & 0.84 & 0.11 \\
\hline Feed efficiency, g/g & 0.696 & 0.660 & 0.694 & 0.687 & 0.01 & 0.02 & 0.33 & 0.32 & 0.56 & 0.50 \\
\hline \multicolumn{11}{|l|}{35 to $55 \mathrm{~d}$ of age } \\
\hline Body weight $35 \mathrm{~d}$ & 708 & 716 & 729 & 711 & 10.6 & 45.1 & $<0.001$ & 0.40 & 0.60 & 0.41 \\
\hline Weight gain , g/d & 53.4 & 56.8 & 57.5 & 56.9 & 106 & 1.50 & 0.029 & 0.35 & 0.16 & 0.19 \\
\hline Feed intake, g/d & 116 & 121 & 123 & 121 & 2.55 & 3.62 & $<0.001$ & 0.67 & 0.25 & 0.31 \\
\hline Feed efficiency, g/g & 0.464 & 0.474 & 0.471 & 0.471 & 0.006 & 0.009 & 0.005 & 0.62 & 0.81 & 0.58 \\
\hline \multicolumn{11}{|l|}{25 to $55 \mathrm{~d}$ of age } \\
\hline Body weight $55 \mathrm{~d}$ & 1776 & 1847 & 1882 & 1849 & 24.9 & 35.3 & $<0.001$ & 0.59 & 0.13 & 0.15 \\
\hline Weight gain, g/d & 43.9 & 45.5 & 46.2 & 46.6 & 0.94 & 1.33 & 0.063 & 0.44 & 0.20 & 0.67 \\
\hline Feed intake, g/d & 86.8 & 89.9 & 89.7 & 91.4 & 1.92 & 2.73 & 0.002 & 0.38 & 0.41 & 0.78 \\
\hline Feed efficiency, g/g & 0.506 & 0.512 & 0.515 & 0.512 & 0.005 & 0.008 & 0.023 & 0.84 & 0.58 & 0.57 \\
\hline
\end{tabular}


Table 3. Effect of arginine and glutamine supplementation on ileal apparent digestibility of fattening rabbits.

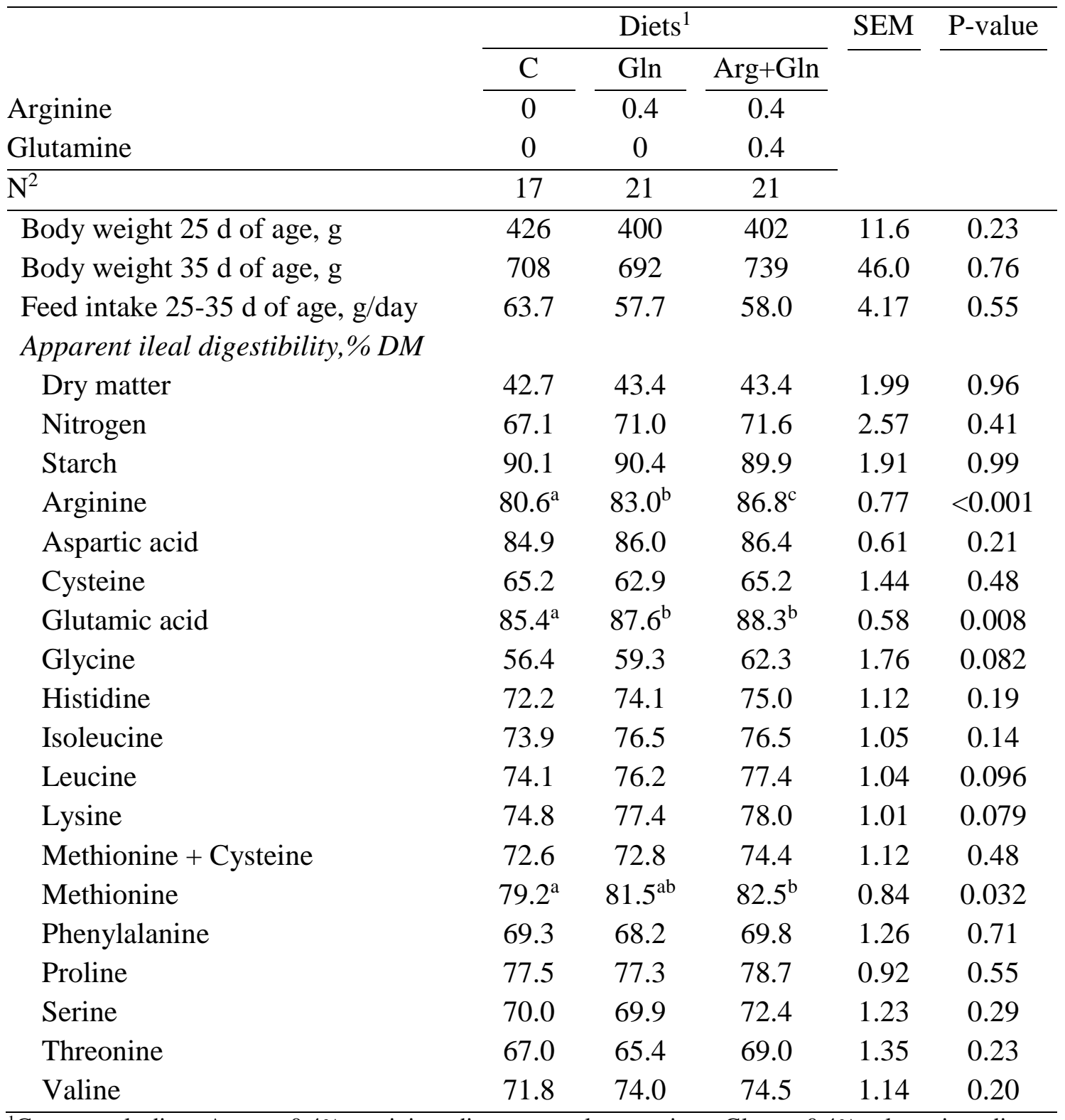

${ }^{1} \mathrm{C}=$ control diet; $\operatorname{Arg}=0.4 \%$ arginine dietary supplementation; $\mathrm{Gln}=0.4 \%$ glutamine dietary supplementation; $\mathrm{Arg}+\mathrm{Gln}=0.4 \%$ arginine $+0.4 \%$ glutamine supplementation. ${ }^{2} \mathrm{~N}$ (pools/treatment): $\mathrm{C}=$ 6; $\mathrm{Gln}=4 ; \mathrm{Arg}+\mathrm{Gln}=5{ }^{\mathrm{a}-\mathrm{c}}$ Diet mean values in the same row with a different superscript differ. $\mathrm{P}<0.05$ 
Table 4. Effect of arginine and glutamine supplementation on fecal apparent digestibility from 32 to $35 \mathrm{~d}$ of age.

\begin{tabular}{|c|c|c|c|c|c|c|c|c|c|}
\hline & \multicolumn{4}{|c|}{ Diets $^{1}$} & \multicolumn{2}{|c|}{ SEM } & \multicolumn{3}{|c|}{$\mathrm{P}$-value } \\
\hline & $\mathrm{C}$ & Arg & Gln & Arg+Gln & Arg and Gln & $\operatorname{Arg} \times$ Gln & Arg & Gln & $\operatorname{Arg} \times \mathrm{Gln}$ \\
\hline Arginine & 0 & 0 & 0.4 & 0.4 & & & & & \\
\hline Glutamine & 0 & 0.4 & 0 & 0.4 & & & & & \\
\hline$\overline{\mathrm{N}}$ & 8 & 8 & 9 & 8 & & & & & \\
\hline Feed intake 32-35d & 74.5 & 86.2 & 86.2 & 75.2 & 7.65 & 10.8 & 0.97 & 0.97 & 0.30 \\
\hline \multicolumn{10}{|c|}{ Apparent faecal digestibility, $\% D M$} \\
\hline Dry matter & $65.1^{\mathrm{a}}$ & $68.9^{b}$ & $70.3^{b}$ & $68.7^{\mathrm{b}}$ & 0.62 & 0.88 & 0.22 & 0.007 & 0.005 \\
\hline Energy & $65.5^{\mathrm{a}}$ & $69.3^{\mathrm{b}}$ & $70.1^{b}$ & $68.1^{\mathrm{ab}}$ & 0.71 & 1.01 & 0.37 & 0.11 & 0.008 \\
\hline Nitrogen & $80.3^{\mathrm{a}}$ & $84.1^{\mathrm{b}}$ & $85.7^{\mathrm{b}}$ & $83.3^{\mathrm{b}}$ & 0.69 & 0.97 & 0.48 & 0.026 & 0.003 \\
\hline Neutral detergent fibre & 23.9 & 26.5 & 33.8 & 31.6 & 1.06 & 1.49 & 0.90 & $<0.001$ & 0.11 \\
\hline
\end{tabular}

${ }^{1} \mathrm{C}=$ control diet; Arg $=0.4 \%$ arginine dietary supplementation; Gln $=0.4 \%$ glutamine dietary supplementation; Arg+Gln $=0.4 \%$ arginine $+0.4 \%$ glutamine supplementation. ${ }^{2} \mathrm{~N}=$ number of rabbits/treatment. ${ }^{\mathrm{a}-\mathrm{c}}$ Diet mean values in the same row with a different superscript differ. $\mathrm{P}<0.05$. 
Table 5. Effect of arginine and glutamine supplementation on body chemical composition and energy content of weaning rabbits at 25 and $55 \mathrm{~d}$ of age.

\begin{tabular}{|c|c|c|c|c|c|c|c|c|c|c|c|}
\hline & \multicolumn{4}{|c|}{ Diets $^{1}$} & \multicolumn{2}{|c|}{ SEM } & \multicolumn{5}{|c|}{ P-value } \\
\hline & $\mathrm{C}$ & $\operatorname{Arg}$ & Gln & $\overline{A r g}+\mathrm{Gln}$ & Arg and Gln & $\operatorname{Arg} \times \mathrm{Gln}$ & $\mathrm{Cov}^{3}$ & $\operatorname{Cov}^{4}$ & Arg & Gln & $\operatorname{Arg} \times \mathrm{Gln}$ \\
\hline Arginine & 0 & 0.4 & 0.4 & 0.4 & & & & & & & \\
\hline Glutamine & 0 & 0 & 0 & 0.4 & & & & & & & \\
\hline $\mathrm{N}^{2}$ & 17 & 10 & 14 & 18 & & & & & & & \\
\hline Body weight $25 \mathrm{~d}$ of age, $\mathrm{g}$ & 388 & 378 & 435 & 391 & 12.2 & 17.1 & - & - & 0.12 & 0.086 & 0.32 \\
\hline Body weight $55 \mathrm{~d}$ of age, $\mathrm{g}$ & 1897 & 1915 & 1891 & 1828 & 27.9 & 39.4 & $<0.001$ & - & 0.56 & 0.25 & 0.31 \\
\hline \multicolumn{12}{|l|}{ Carcass composition, \%DM } \\
\hline \multicolumn{12}{|l|}{$25 \mathrm{~d}$ of age } \\
\hline Moisture & 72.5 & 72.5 & 72.7 & 72.6 & 0.08 & 0.12 & - & - & 0.60 & 0.099 & 0.81 \\
\hline Protein & 60.1 & 60.0 & 59.9 & 59.9 & 0.09 & 0.13 & - & - & 0.70 & 0.49 & 0.93 \\
\hline Fat & 20.3 & 20.4 & 20.3 & 20.2 & 0.19 & 0.27 & - & - & 0.93 & 0.55 & 0.64 \\
\hline Ash & 17.2 & 17.2 & 17.0 & 17.3 & 0.11 & 0.15 & - & - & 0.45 & 0.97 & 0.53 \\
\hline Energy, kJ /100g & 2035 & 2034 & 2044 & 2028 & 8.04 & 11.3 & - & - & 0.45 & 0.88 & 0.49 \\
\hline \multicolumn{12}{|l|}{$55 \mathrm{~d}$ of age, $\% \mathrm{DM}$} \\
\hline Moisture & 68.3 & 68.4 & 68.2 & 68.6 & 0.18 & 0.25 & $<0.001$ & 0.12 & 0.37 & 0.89 & 0.68 \\
\hline Protein & 56.4 & 56.6 & 56.4 & 56.9 & 0.20 & 0.28 & $<0.001$ & 0.34 & 0.26 & 0.60 & 0.45 \\
\hline Fat & 28. & 28.1 & 28.6 & 27.7 & 0.31 & 0.44 & $<0.001$ & 0.075 & 0.12 & 0.70 & 0.63 \\
\hline Ash & 12.9 & 13.2 & 13.0 & 13.3 & 0.24 & 0.34 & 0.054 & 0.16 & 0.33 & 0.85 & 0.93 \\
\hline Energy, $\mathrm{kJ} / 100 \mathrm{~g}$ & 2405 & 2385 & 2403 & 2374 & 16.6 & 23.4 & 0.005 & 0.12 & 0.31 & 0.78 & 0.86 \\
\hline
\end{tabular}

${ }^{1} \mathrm{C}=$ control diet; $\operatorname{Arg}=0.4 \%$ arginine dietary supplementation; Gln $=0.4 \%$ glutamine dietary supplementation; $\mathrm{Arg}+\mathrm{Gln}=0.4 \%$ arginine $+0.4 \%$ glutamine supplementation. ${ }^{2} \mathrm{~N}=$ number of rabbit/treatment. ${ }^{3}$ weight at weaning $(25 \mathrm{~d}) .{ }^{4}$ initial body corporal condition $(25 \mathrm{~d})$. 
Table 6. Effect of dietary arginine and glutamine supplementation on nitrogen and energy balance of rabbits from 25 to $55 \mathrm{~d}$ of age.

\begin{tabular}{|c|c|c|c|c|c|c|c|c|c|}
\hline & \multicolumn{4}{|c|}{ Diets $^{1}$} & \multicolumn{2}{|c|}{ SEM } & \multicolumn{3}{|c|}{ P-value } \\
\hline & $\mathrm{C}$ & Arg & Gln & Arg+Gln & Arg and Gln & $\operatorname{Arg} \times \mathrm{Gln}$ & Arg & Gln & $\operatorname{Arg} \times$ Gln \\
\hline Arginine & 0 & 0 & 0.4 & 0.4 & & & & & \\
\hline Glutamine & 0 & 0.4 & 0 & 0.4 & & & & & \\
\hline$\overline{\mathrm{N}^{2}}$ & 17 & 10 & 14 & 18 & & & & & \\
\hline \multicolumn{10}{|l|}{ Nitrogen intake, $\mathrm{g} / \mathrm{kg} \mathrm{BW} \mathrm{B}^{0.75}$ and day } \\
\hline $\mathrm{N}_{\mathrm{i}}$ & 1.962 & 2.034 & 1.822 & 2.033 & 0.030 & 0.043 & 0.002 & 0.11 & 0.12 \\
\hline $\mathrm{DN}_{\mathrm{i}}$ & 1.575 & 1.708 & 1.561 & 1.693 & 0.025 & 0.036 & $<0.001$ & 0.70 & 0.99 \\
\hline $\begin{array}{l}\text { Nitrogen retained carcass, g/kg } \mathrm{BW}^{0.75} \\
\text { and day }{ }^{3}\end{array}$ & 0.748 & 0.748 & 0.734 & 0.735 & 0.010 & 0.014 & 0.99 & 0.34 & 0.99 \\
\hline Nitrogen efficiency, NR carcass/DNi & 0.471 & 0.437 & 0.482 & 0.441 & 0.007 & 0.010 & $<0.001$ & 0.48 & 0.77 \\
\hline \multicolumn{10}{|l|}{ Nitrogen losses, $\mathrm{g} / \mathrm{kg} \mathrm{BW} \mathrm{BW}^{0.75}$ and day } \\
\hline Skin and viscera & 0.494 & 0.517 & 0.469 & 0.503 & 0.011 & 0.017 & 0.098 & 0.25 & 0.75 \\
\hline Faeces & $0.386^{\mathrm{c}}$ & $0.324^{\mathrm{b}}$ & $0.260^{\mathrm{a}}$ & $0.340^{\mathrm{b}}$ & 0.005 & 0.007 & 0.20 & $<0.001$ & $<0.001$ \\
\hline Urine & 0.332 & 0.445 & 0.358 & 0.455 & 0.033 & 0.046 & 0.030 & 0.70 & 0.87 \\
\hline \multicolumn{10}{|l|}{ Energy intake, MJ/ kg BW0.75 and day } \\
\hline GEi & 1.185 & 1.228 & 1.099 & 1.231 & 0.019 & 0.027 & 0.002 & 0.12 & 0.11 \\
\hline DEi & 0.776 & 0.851 & 0.770 & 0.838 & 0.012 & 0.018 & $<0.001$ & 0.60 & 0.85 \\
\hline $\begin{array}{l}\text { Energy retained carcass, } \mathrm{kJ} / \mathrm{kg} \mathrm{BW}^{0.75} \\
\text { and day }{ }^{4}\end{array}$ & 195 & 192 & 201 & 186 & 4.50 & 6.33 & 0.16 & 0.96 & 0.32 \\
\hline Energy efficiency, ER carcass /DEi & 0.250 & 0.231 & 0.253 & 0.238 & 0.003 & 0.004 & $<0.001$ & 0.23 & 0.71 \\
\hline \multicolumn{10}{|l|}{ Energy losses, MJ/ kg BW 0.75 and day } \\
\hline Skin and viscera, & 0.129 & 0.137 & 0.131 & 0.124 & 0.003 & 0.004 & 0.89 & 0.16 & 0.069 \\
\hline Faeces & $0.409^{c}$ & $0.377^{\mathrm{b}}$ & $0.328^{\mathrm{a}}$ & $0.392^{\mathrm{bc}}$ & 0.006 & 0.008 & 0.060 & $<0.001$ & $<0.001$ \\
\hline Urine + heat production & 0.452 & 0.521 & 0.438 & 0.529 & 0.018 & 0.026 & 0.003 & 0.89 & 0.68 \\
\hline
\end{tabular}

${ }^{1} \mathrm{C}=$ control diet; $\operatorname{Arg}=0.4 \%$ arginine dietary supplementation; $\mathrm{Gln}=0.4 \%$ glutamine dietary supplementation; $\mathrm{Arg}+\mathrm{Gln}=0.4 \%$ arginine $+0.4 \%$ glutamine supplementation. ${ }^{2} \mathrm{~N}=$ number of rabbit/treatment. ${ }^{3}$ Nitrogen retained in carcass $\left(\mathrm{g} / \mathrm{kg} \mathrm{BW}^{0.75}\right.$ and day) was used as covariate for nitrogen efficiency in carcass (NR carcass/DNi). Covariate was significant $(\mathrm{P}<0.001)$. Skin and viscera $(\mathrm{g} \mathrm{N} / \mathrm{kg}$ $\mathrm{BW}^{0.75}$ and day): ( $\mathrm{g} \mathrm{N}$ retained in vivo $-\mathrm{g}$ retained in carcass) $/ \mathrm{kg} \mathrm{BW}^{0.75}$ and day. Faeces $\left(\mathrm{g} / \mathrm{kg} \mathrm{BW}^{0.75}\right.$ and day): (Total $\mathrm{N}$ intake - $\left.\mathrm{DN}_{\mathrm{i}}\right) / \mathrm{kg} \mathrm{BW}^{0.75}$ and day. Urine $\left(\mathrm{g} / \mathrm{kg} \mathrm{BW}{ }^{0.75}\right.$ and day): $\left(\mathrm{DN}_{\mathrm{i}}-\mathrm{N}\right.$ Retained in carcass$\mathrm{N}$ excreted in skin and viscera $) / \mathrm{kg} \mathrm{BW}^{0.75}$ and day. ${ }^{4}$ Energy retained in carcass $\left(\mathrm{kJ}^{\circ} / \mathrm{kg} \mathrm{BW}^{0.75}\right.$ and day) as a covariate for energy efficiency in carcass $\left(\mathrm{ER}\right.$ carcass $\left./ \mathrm{DE}_{\mathrm{i}}\right)$. Covariate was significant $(\mathrm{P}<0.001)$. Skin and viscera (MJ/ $\mathrm{kg} \mathrm{BW}^{0.75}$ and day): (MJ gross energy retained in vivo - MJ gross energy retained in carcass) $/ \mathrm{kg}$ $\mathrm{BW}^{0.75}$ and day. Faeces $\left(\mathrm{MJ} / \mathrm{kg} \mathrm{BW}^{0.75}\right.$ and day): (Gross energy intake $\left.-\mathrm{DE}_{\mathrm{i}}\right) / \mathrm{Kg} \mathrm{BW}^{0.75}$ and day. Urine + heat production $\left(\mathrm{MJ} / \mathrm{kg} \mathrm{BW}^{0.75}\right.$ and day): ( $\mathrm{DE}_{\mathrm{i}}-$ Gross energy retained in carcass- GE excreted in skin and viscera) $/ \mathrm{kg} \mathrm{BW}^{0.75}$ and day. 

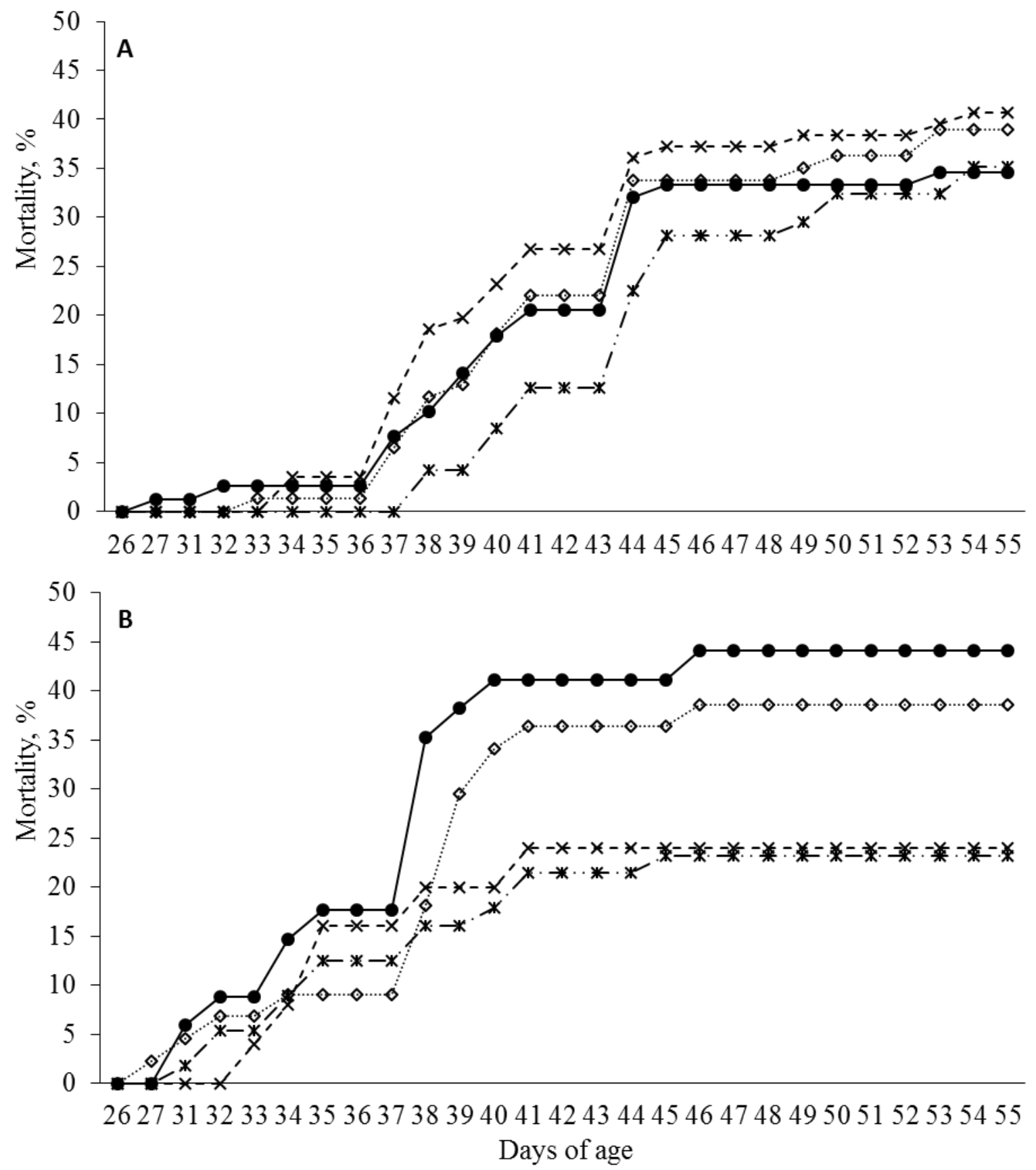

Figure 1. Evolution of mortality by treatment $\left(\mathrm{C} \rightarrow\right.$-Arg $\quad \cdots$, Gln $\quad-\mathbf{x}^{-}$nd Arg+Gln $\quad * \cdot-$ ) with the age in rabbits of trial 1a (T1a) fed with the experimental diets during all the fattening, (Fig 1A) and in rabbits of trial 1b (T1b) fed with experimental diets from 25 to 35 $\mathrm{d}$ of age and fed the $\mathrm{C}$ diet from 35 to $55 \mathrm{~d}$ of age (Fig 1B). Initial $\mathrm{N}$ T1a ( $\mathrm{n}^{\circ}$ cages/diet; 2-3 rabbits/cage): $\mathrm{C}=28$ (78 rabbits); $\mathrm{Arg}=30$ (77 rabbits); Gln $=33$ (86 rabbits) and Arg+Gln $=25$ (71 rabbits). Initial N T1b ( $n^{\circ}$ cages/diet; 2-3 rabbits/cage): $\mathrm{C}=16$ (39 rabbits); $\mathrm{Arg}=20$ (49 rabbits); Gln = 13 (30 rabbits) and Arg+Gln $=25$ (61 rabbits). $\mathrm{P} \geq 0.24$ for T1a and $\mathrm{P}=$ 0.053 (25- $35 \mathrm{~d}$ of age) and $\mathrm{P}=0.042$ (25-55 d of age) for Gln in T1b. 


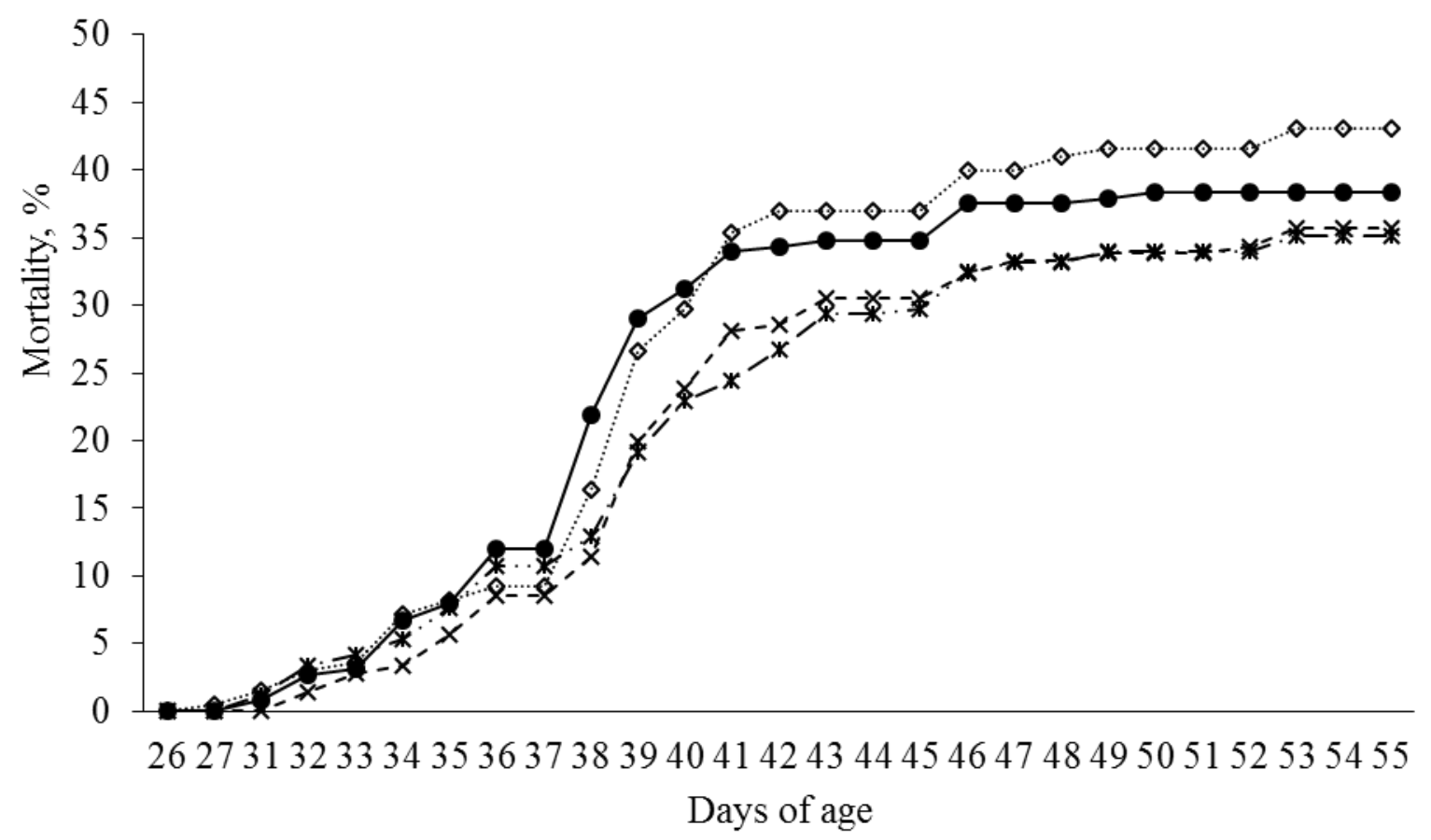

Figure 2. Evolution of mortality of trial $1 \mathrm{~b}$ (T1b), trial 2 (T2) and trial 3 (T3) by treatment $\left(\mathrm{C} \longrightarrow-\right.$, Arg $\cdots \cdots \cdots$, Gln - $\mathbf{x}^{--}$and Arg+Gln $\left.* \cdot-\right)$ ) with the age in rabbits fed with experimental diets from 25 to $35 \mathrm{~d}$ of age and with the $\mathrm{C}$ diet from 35 to $55 \mathrm{~d}$ of age (Fig 1B). Initial $N$ ( $n^{\circ}$ cages/diet; 2-3 rabbits/cage): $C=88$ (229 rabbits); $\operatorname{Arg}=75$ (200 rabbits); Gln $=81$ (215 rabbits) and Arg+Gln $=103$ (267 rabbits). $\mathrm{P}=0.14$ (25- $35 \mathrm{~d}$ of age) and $\mathrm{P}=0.10(25-55 \mathrm{~d}$ of age) for Gln in T1b. 


\subsection{Effect of pre- and post-weaning dietary supplementation with arginine and glutamine on rabbit performance and intestinal health.}

\subsubsection{Introduction.}

The use of feed additives for the correct development of the gastrointestinal tract along the neonatal and weaning phases is becoming a common practice to prevent diseases in young productive animals (de Lange et al., 2010). Among them amino acids, and especially those with functional properties such as arginine and glutamine, have been proven to be nutritionally essentials for neonates and under stressful conditions such as weaning (Rezaei et al., 2013; Wu, 2013), where important physiological and metabolic changes occurs (Chapter 3.2).

Despite arginine can be synthetized from other amino acids (glutamine, glutamate and proline) in young animals is considered an essential amino acid as their needs exceeds endogenous synthesis (Ruth and Field, 2013; Wu, 2013). It is an important $\mathrm{N}$ carrier and precursor for amino acids, proteins and polyamines needed for immune cell proliferation (Rezaei et al., 2013). Also, it is a substrate for the synthesis of nitrogen oxide (NO) a powerful mediator in both innate and adaptive immunity (Ruth and Field, 2013). Arginine supplementation $(0.5-1 \% \mathrm{w} / \mathrm{w})$ to young pigs supports intestinal epithelial growth and maintains gut barrier integrity and function against bacterial toxins (Ruth and Field, 2013).

Glutamine is also considered an indispensable amino acid for intestinal development and function (Lobley et al., 2001; Rezaei et al., 2013; Ruth and Field, 2013). It provides energy and it is the precursor for other amino acids (including citruline, arginine and glutamate) and derivatives needed for enterocytes and immune cells to function and proliferate (Rezaei et al., 2013; Ruth and Field, 2013). Moreover, it has been proven to play important roles under disease and stress situations by maintaining epithelial integrity and GALT function (Lobley et al., 2001; Ruth and Field, 2013; Wu 2013). Recently, beneficial effects of glutamine on gut health have been also associated to a direct use of this amino acid by commensal bacteria (Dai et al., 2013).

Several authors observed that the combination of arginine and glutamine have beneficial additive effects (Gennari et al., 1995; Kul et al., 2009; Zhou et al., 2012). Our previous research in growing rabbits, (Chamorro et al., 2010), suggest that diets 
supplemented with $1 \%$ of glutamine and $0.5 \%$ of arginine tend to improve productive performances reducing the presence of Clostridium spp. and Helicobacter ssp. in the caecum and in the ileum. Also, ex vivo experiments suggest that the combination of arginine and glutamine decrease the production of pro-inflammatory cytokines (Lecleire et al., 2008).

The aim of this study was to determine if the rabbit gastrointestinal tract development is positively affected by feeding pre-weaning (pregnancy period) and postweaning diets supplemented with arginine, glutamine and their interaction.

\subsubsection{Materials and methods.}

\subsubsection{Animals and housing.}

Rabbits (New Zealand White $\times$ Californian, $\mathrm{V} \times \mathrm{R}$ from UPV, Valencia, Spain) were offspring of primiparous does. They were nursed by their mothers until $25 \mathrm{~d}$ of age. Does and offspring were housed and managed as described in Chapter 3.1. At the time of weaning ( $25 \mathrm{~d}$ of age) rabbits were housed collectively in groups of 2 or 3 animals per cage $(650 \mathrm{~mm}$ x $250 \mathrm{~mm}$ x $330 \mathrm{~mm})$. Rabbits were fed with the same treatments described in Chapter 3.1. In total 471 rabbits weighting 390 $\pm 82 \mathrm{~g}$ were allocated into 190 cages and assigned the same dietary treatment as during the lactating (pre-weaning) period. Housing conditions were controlled during the whole experimental period. The farm temperature was maintained between 18 and $24^{\circ} \mathrm{C}$ with $12 \mathrm{~h}$ of light and $12 \mathrm{~h}$ of darkness. All the experimental procedures used were approved by the Animal Ethic Committee of the Universidad Politécnica de Madrid, according with principles of care of animals in experimentation (Spanish Royal Decree, 53/2013, BOE, 2013).

\subsubsection{Bacterial translocation to mesenteric lymphoid nodes.}

Six days after parturition one kit per litter (24 litters; 6 litters/diet) was slaughtered by cervical dislocation at 12:00 h a.m. The mesenteric lymph nodes (MLN) located at the base of the small-bowel mesentery was excised completely under sterile conditions for bacterial analysis. The nodes, weighing on average $19 \pm 9 \mathrm{mg}$, were dissected free from fat and placed in a sterile eppendorf containing $1 \mathrm{ml}$ of sterile peptone water. Later, they were homogenized using a mixer mill (Reisch MM 400) by applying a frequency of 22 $\mathrm{Hz}$ during 2 minutes. Each $\mathrm{ml}$ of MLN homogenized was blended with other $9 \mathrm{ml}$ of peptone water, vortexed and further diluted (3 dilutions per sample). Dilutions were 
plated onto blood agar (columbia agar + sheep blood, Oxoid S.A.) and incubated at $37^{\circ} \mathrm{C}$ for $48 \mathrm{~h}$ in aerobic conditions, for aerobes growth, or in jars of 61 with anaerobic atmosphere (two AeroGen 3.51 per jar; Oxoid S.A.) for anaerobes. Facultative anaerobes microorganisms were incubated in jars of 61 with one carbon dioxide generating envelopes (AeroGen 3.5 1; Oxoid S.A.). For each analysis, a blank with sterile peptone water was cultured onto blood agar to verify there was not environmental contamination. After incubation, colonies were counted and recorded as CFU per mg of sample.

\subsubsection{Gut histology and enzymatic activity.}

Forty-eight rabbits with $6 \mathrm{~d}$ of age (12/diet) and 40 rabbits with 25 and $35 \mathrm{~d}$ of age respectively, (10/diet) were killed by cervical dislocation and $3 \mathrm{~cm}$ of middle part of jejunum collected in $10 \%$ buffered neutral formaldehyde solution ( $\mathrm{pH} 7.2$ to 7.4 ) for histological analysis. Also, at 25 and $35 \mathrm{~d}$ of age, tissue samples from middle part of jejunum $(6 \mathrm{~cm}$ each) were collected to determine intestinal sucrose enzymatic activity. This tissue was cleaned with saline solution, snap frozen and stored at $-80^{\circ} \mathrm{C}$.

Collected jejunal samples were gradually dehydrated in an ethanol series (50 to $100 \%$ ) and infiltrated with paraffin wax using tissue processor LEICA ASP 300. Samples were sectioned at $5 \mu \mathrm{m}$ with microtome LEICA RM 2255. The slides were stained with Alcian blue to visualize acidic mucins (Kiernan, 1999), by using an automatic procedure (ArtisanTM Link Special Staining System). The sections were placed in acetic acid$\mathrm{AB} 2.5, \mathrm{pH} 2.5$, for $5 \mathrm{~min}$, and then they were placed in alcian blue-AB 2.5, $\mathrm{pH} 2.5$ for 10 min, at $37^{\circ} \mathrm{C}$ and subsequently washed in water six times. The sections were counterstained with eosin, dehydrated, and covered with a cover slip using nuclear fast red-AB 2.5 for 10 min and subsequently washed in water six times (Brunsgaard, 1997). One slide containing jejunal section was prepared for each sample and all of them were viewed at 40X magnification using an Olympus BX-40 light microscope. Images were digitally captured for later analysis using Soft software version 3.2 C4040Z (Soft Imaging System, Olympus, GmbH, Hamburg, Germany), and analyzed eye blinded by the same person. Villous height and crypt depth were measured individually (Hampson, 1986) and an average of the measurements was obtained for each animal. The amount of mucin granulates secreted by goblet cell from each villi measured were counted. Sucrose enzymatic activity in jejunal samples was analyzed as previously described in GomezConde et al. (2007). 


\subsubsection{Phenotypical and functional analysis of intraepithelial lymphocytes from the} appendix.

Appendix were taken from 24 animals (6/diet) at 6, 25 and $35 \mathrm{~d}$ of age. After removal, tissue was placed in ice-cold $10 \mathrm{mM}$ PBS, $\mathrm{pH} 7.4$ and immediately processed for intraepithelial lymphocyte isolation. For this, appendix samples were cut in small pieces with a scalpel and incubated in 9\% HBSS containing Dispase I (100 u; Sigma, Alcobendas España), DNase I (30ug/ml; Sigma, Alcobendas España), 10\% Fetal Calf Serum and HEPES $(1,5 \%$; $\mathrm{pH}=7,2)$ following the method of (Montufar-Solis and Klein, 2006). Isolated lymphocytes were count in a Neubauer chamber and stored at $-80^{\circ} \mathrm{C}$ in RPMI/ DMSO (12\%) at a final concentration of $106 \mathrm{cel} / \mathrm{ml}$.

For the phenotypic characterization of lymphocytes, cells were incubated in commercial monoclonal antibodies and flow cytometry acquisition was performed on an Accuri cytometer (BD Accuri Cytometers, Ann Arbor, MI). The following antibodies were used for flow cytometry: anti-rabbit CD45+ (VMRD INC, Pullman WA, USA) for total lymphocytes, CD5+ (BioRad) for T lymphocytes, CD4+ for T helper lymphocytes, and CD8+ (AbynteK Biopharma, S.L, Bizkaia, Spain) for cytotoxic T lymphocytes.

For lymphocyte functional response, total RNA was isolated from approximately 2 x 106 cells using the GenElute Mammalian Total RNA Miniprep kit (Sigma-Aldrich, St Louise, MO, USA) according to manufacturer's instructions. The relative gene expression of selected interleukins (IL) was analyzed by using real-time, quantitative PCR. First strand cDNA was synthesized using the High-Capacity cDNA Archive Kit (Applied Biosystems Foster City, CA, USA) according to the manufacturer's instructions. Target ILs were selected for their known functional proinflammatory (IL-2, IL-6, IL-8) and antiinflamatory (IL-10) roles in the appendix. The specific primers for rabbit GAPDH and hypoxanthine phosphoribosyltransferase (HPRT) (housekeeping genes) and those for IL-10 were obtained from Godornes et al. (2007) and Chamorro et al. (2010). Those for IL-2, IL-6 and IL-8 were designed by us using Primer Express ${ }^{\circledR}$ v.2 (Applied Biosystems, Foster City, CA, USA) (Table 3). The quantitative PCR was performed in an ABI Prism 7300 Sequence Detector System (Applied Biosystems, Foster City, CA, USA). Each reaction mix consisted on around $100 \mathrm{ng}$ of first strand cDNA as a template, specific primers, ultra-purified water and SYBR® Green Master Mix (Applied Biosystems Foster City, CA, USA) as fluorescent DNA intercalating agent. All samples were run in triplicate and quantified by normalizing the cytokine signal of GADPH and HPRT. 


\subsubsection{Chemical analysis.}

Procedures of the AOAC (2000) were used to determine the dietary concentrations of DM (934.01), ash (942.05), nitrogen (954.01), ether extract (920.39), starch (amyloglucosidase- $\alpha$-amylase method; method 996.11) and total dietary fibre (985.29). Dietary aNDFom, ADFom and lignin (sa) were determined sequentially using the filter bag system (Ankom Technology, New York, NY). Dietary aNDFom was determined according to Mertens et al. (2002) using a thermo-stable amylase without any sodium sulphite added. Dietary ADFom and ADL were analyzed according to Goering and Van Soest (1970), respectively. The soluble fiber was calculated as the difference between total dietary fibre and aNDFom (both corrected for ash and protein). Gross energy was measured by adiabatic bomb calorimeter (model 356, Parr Instrument Company, Moline, IL). Amino acids were determined after acid hydrolysis using a Beckman System 6300HPA AA analyzer (Fullerton, CA). Samples were hydrolyzed by reflux in $25 \mathrm{~mL}$ of $\mathrm{HCl} 6 \mathrm{~N}$ with $10 \mathrm{~g} / \mathrm{L}$ of added phenol for $24 \mathrm{~h}$ at $120^{\circ} \mathrm{C}$. For the determination of sulfur AA (Met and Cys), samples were oxidized with per-formic acid at $0^{\circ} \mathrm{C}$ for $16 \mathrm{~h}$ and then neutralized with $0.5 \mathrm{~g}$ of sodium meta-bisulphite before analysis. During acid hydrolysis, tryptophan was destroyed and was not determined.

\subsubsection{Statistical analysis.}

Rabbit performance (BW, ADG, ADFI and G:F) was analyzed using a variance analysis with the MIXED procedure of SAS (SAS Inst., Cary, NC) with, Arg level, Gln level and their interactions as a fixed effects and the number of rabbits per cage at $25 \mathrm{~d}$ of age as a covariate. Mortality was analyzed using a logistic regression (GENMOD procedure of SAS considering a binomial distribution) including Arg level, Gln level and their interactions in the model, and the results were transformed from the logit scale. Bacterial translocation were analyzed as a completely randomized design with Arg level, Gln level and their interaction as the main sources of variation by using the GLM procedure of SAS. Means were compared using a protected t-test, and the differences were considered significant at $\mathrm{P}<0.05$. Mucosal morphology, lymphocyte proportions and cytokine expression were analyzed by repeated measurement model with the MIXED procedure of SAS. The model included Arg level, Gln level, their interactions and the age (repeated measurement) as fixed effects. The litter was considered as a random effect. 


\subsubsection{Results.}

No significant differences on animal performance were observed among dietary treatments (Table 2). Rabbits showed similar weight gain, feed intake feed efficiency and final body weight during the experimental period averaging $32.4 \mathrm{~g}, 45.0 \mathrm{~g}, 0.722 \mathrm{~g} / \mathrm{g}$ and $739 \mathrm{~g}$ respectively $(\mathrm{P} \geq 0.28)$. Also, dietary treatment did not affect the mortality from 25 to $35 \mathrm{~d}$ of age which was on average $2.33 \%(\mathrm{P} \geq 0.27)$.

At $6 \mathrm{~d}$ of age, bacterial translocation to MLN was observed, with aerobes, anaerobes and facultative anaerobes present on average at 5.73, 5.2, and 7.84 CFU/mg MLN, respectively (Table 3). Kits from rabbit does supplemented with Gln tended to reduce the total number of both aerobic (2.62 vs $5.74 \mathrm{CFU} / \mathrm{mg} \mathrm{MLN} ; \mathrm{P}=0.091)$ and facultative anaerobic bacteria (2.63 vs $5.86 \mathrm{CFU} / \mathrm{mg} \mathrm{MLN}$; $\mathrm{P}=0.10$ ) compared to those fed the no supplemented Gln diets.

Dietary treatments did not affect jejunal villous height, crypt depth or villous height to crypt depth ratio (Table 4). Moreover, the number of goblet cells and sucrose activity in the jejunum was not affected by diet (Table 4). However, villous height decreased by $17.7 \%$, crypt depth increased $110 \%$ and the number of goblet cells per villous increased by $393 \%(\mathrm{P}<0.05)$ in rabbits at $25 \mathrm{~d}$ of age compared to rabbits at $6 \mathrm{~d}$ of age. In addition, the villous height/crypt depth ratio decreased from 6 to $25 \mathrm{~d}$ of age (16.3 vs. 6.36; $\mathrm{P}<$ 0.05). From 25 to $35 \mathrm{~d}$ of age, villous height recovered its value of $6 \mathrm{~d}$ of age and crypt depth increased by $4.7 \%(\mathrm{P}<0.05)$. This led to a villous height/crypt depth ratio increase from 25 to $35 \mathrm{~d}$ of age (6.36 vs. 7.38; $\mathrm{P}<0.05)$. The number of goblet cells per villous also increased by $33 \%$ from 25 to $35 \mathrm{~d}$ of age ( $\mathrm{P}>0.05$ ). Supplementation with Gln increased maintained villous height at 25 and at $35 \mathrm{~d}$ of age compared to the no supplemented Gln diets ( $\mathrm{P}=0.019$ for diet $\mathrm{x}$ age interaction) (Figure 1). Sucrose activity increased by $81 \%$ from 25 to $35 \mathrm{~d}$ of age $(\mathrm{P}<0.001)$.

The percentages of CD45+CD5+, CD45+CD4+ and CD45+CD8+ intraepithelial lymphocytes (IEL) were not affected by dietary means $(\mathrm{P}=0.44$; Table 5$)$. However, the proportions of CD45+CD4+ tended to decrease $(\mathrm{P}=0.065)$ from 6 to $25 \mathrm{~d}$ of age and then to increase again up to $35 \mathrm{~d}$ of age. Also, the percentage of CD45+CD8+ tended to increase $(\mathrm{P}=0.099)$ with age.

The expression of IL-2 in the appendix was significantly affected by age $(\mathrm{P}<0.001)$ with an overexpression at $25 \mathrm{~d}$ compared to 6 and $35 \mathrm{~d}$ (Figure 2). Moreover, glutamine 
significantly increased the expression of IL-2 at 25 and $35 \mathrm{~d}$ of age $(\mathrm{P}=0.01$ for the interaction). The inclusion of dietary Arg did not affected IL-2 expression (data not shown). A similar trend with age was observed for IL-6 who was significantly overexpressed at $25 \mathrm{~d}$ compared to $6 \mathrm{~d}(\mathrm{P}<0.05)$ and $35 \mathrm{~d}(\mathrm{P}<0.001)$ (Figure 3$)$. The inclusion of dietary Arg increased the expression of IL- 6 at $6 \mathrm{~d}$ of age compared to the no supplemented diet $(\mathrm{P}=0.01$ for the interaction). However, a significant IL-6 downregulation was observed at $25 \mathrm{~d}$ of age in Gln fed animals compared to rabbits fed the no supplemented diets ( $\mathrm{P}=0.01$ for the interaction). The expression of IL- 8 in the appendix was affected by age with a significant downregulation $(\mathrm{P}<0.001)$ at $25 \mathrm{~d}$ and $35 \mathrm{~d}$ compared to $6 \mathrm{~d}$ of age (Figure 4). Rabbits fed the Arg diets overexpressed (P < $0.001)$ IL-8 at $6 \mathrm{~d}$ of age while a downregulation $(\mathrm{P}<0.05)$ of this gene was observed at $35 \mathrm{~d}$ of age compared to those fed the no supplemented diets $(\mathrm{P}<0.001$ for the interaction). The inclusion of dietary Gln did not affected IL-8 expression (data not shown). Finally, the expression of IL-10 was significantly $(\mathrm{P}<0.001)$ upregulated in rabbits at 25 and $35 \mathrm{~d}$ of age compared to those at $6 \mathrm{~d}$ (Figure 5). The inclusion of dietary Arg decreased the expression of IL-10 at $35 \mathrm{~d}$ of age compared to the no supplemented $\operatorname{diet}(\mathrm{P}=0.02$ for the interaction). However, a significant IL-10 upregulation was observed at $25 \mathrm{~d}$ of age in rabbits fed the Gln supplemented diets compared to those fed the no supplemented diets ( $\mathrm{P}=0.02$ for the interaction).

\subsubsection{Discussion.}

Individual dietary amino acids such as Gln and Arg are receiving much attention as functional nutrients for young animals as they promote gut health and development (Ruth and Field, 2013; Wu, 2013). It has been shown that dietary supplementation with Gln $(0,5-5 \% \mathrm{w} / \mathrm{w})$ at weaning modulates the piglet GALT function towards an immunetolerant response increasing also the intestinal barrier performance (Ruth and Field, 2013). Also, dietary supplementation with Arg to gilts and piglets (10\% and 0.4-0.8 w/w respectively) increased animal performance and immune function (Mateo et al., 2007; Tan et al., 2009). The purpose of the present study was to assess if the exposure to Gln, Arg or their combination from pregnancy, through the maternal diet, to a post weaning supplemented diet, can stimulate litter performance, gut development and immune function, once we observed a positive effect of the single supplementation of Arg and Gln on the weight of the litters at weaning and litter size at birth (Chapter 3.1). Feeding diets to does and rabbits supplemented with $0.4 \%$ Gln, Arg or their combination did not affect 
animal performance. Studies in piglets, recently reviewed by Hanczakowska and Niwinska (2013), have shown that despite the well reported positive effects of Gln on gut integrity and physiology there is not always a productive enhancement with Gln supplementation. In previous research, we were also unable to detect significant differences on feed efficiency, daily gain or feed intake in young rabbits fed diets supplemented with $1 \%$ Gln (Chamorro et al., 2010). However, studies with Arg seem to be more consistent regarding the positive effects of supplementing this amino acid on preand post-weaning pig performance (Yang et al., 2016). A lack of effect of Arg on performance in our study compared to those in pigs might depend on species differences or dosage used. Also, the combination of Gln and Arg showed no significant improvement on performance as previously reported (Chamorro et al., 2010).

Intestinal bacterial translocation to MLN is a spontaneous event during rabbit development that peaks at around $6 \mathrm{~d}$ of age and then decreases as the gut barrier mechanisms mature (Urao et al., 1995). In the present study, aerobic, facultative aerobic and anaerobic bacteria were isolated from MLN of rabbits at $6 \mathrm{~d}$ of age. Moreover, there was a tendency to decrease the total and facultative anaerobe translocation in the litters of does fed the Gln supplemented diets. A decreased bacterial translocation to MLN as the rabbit ages might be related to a higher degree of intestinal mucosal maturation and function triggered by the presence of milk components such as immune cells, Gln or epidermal growth factor (Okuyama et al., 1998). Gut maturation includes increase number of goblet cells, higher villus, or T lymphocyte proliferation (Urao et al., 1995; Okuyama et al., 1998). Sows fed diets supplemented with $2.5 \%$ Gln significantly increased by $265 \%$ the concentration of this amino acid in the milk (Kitt et al., 2004). Therefore, it is plausible to relate the lower MLN bacterial counts in our study with a higher presence of Gln in the milk of does fed the Gln supplemented diets. However, we were unable to detect a significant increase of goblet cells, villous height or T lymphocyte proportions in rabbits fed the Gln supplemented diets. Thus, future research with higher Gln supplementation is desired to corroborate the potential benefit of supplementing does with this amino acid on bacterial translocation.

The inclusion of Gln or Arg has been proven to support mucosal integrity by increasing or maintaining villous height and crypt depth in pre- and post-weaning healthy piglets (reviewed by Ruth and Field, 2013). In the present study, we were unable to detect significant differences on gut histology and function with dietary supplementation of Gln, 
Arg or their combination as previously reported (Chamorro et al., 2010). However, in agreement with studies in piglets (Wu et al., 1996) and rabbits (Gutierrez et al., 2003; Carabaño et al., 2008) a decrease in villous height was observed around weaning in the jejunum, although it may depend on the type of diet supplied (Gómez-Conde et al., 2007). Moreover, villous height in jejunum was maintained at pre-weaning levels in rabbits fed Gln as described by Wu et al. (1996) in pigs consistent with its preventive role on villous atrophy around weaning. Crypt depth, the number of goblet cells and sucrose activity progressively increased with age as an indicative of gut maturity (Carabaño et al., 2008; Bivolarski and Vachkova, 2014), but were not affected by dietary means.

Glutamine plays a key role on lymphocyte function and cytokine production in healthy weaning piglets (Ruth and Field, 2013). It is a source of energy for lymphocyte proliferation and modulates pro- and anti-inflammatory cytokine production in intestinal epithelial cells (Coëffier et al., 2010; Wu et al., 2011). Arginine also has an important role on immune cell function through the synthesis of NO favouring immune cell proliferation and activity (Suchner et al., 2002). In the present study, the percentage of CD45+CD5+ was not altered by diet or age. Despite intestinal T cells mainly express CD5+ in the rabbit appendix most B cells express CD5+, so our results are in agreement with the observed maintenance of this kind of immune cells along time in the appendix of healthy rabbits (Pospisil et al., 2006). The percentage of IEL CD45+CD4+ and CD45+CD8+ were not affected by dietary treatments, however their proportions tended to change with age. The proportions of CD4+ decreased from 6 to $25 \mathrm{~d}$ of age and then increased again. On the other hand, CD8+ increased with age. This is in agreement with Jeklova et al. (2007b) who reported a decreased CD4+/CD8+ ratio in rabbit spleen, lymph nodes and circulation supported by a significant increase in CD8+ T-lymphocytes as the rabbit ages. An increase in a controlled $\mathrm{T}$ cytotoxic response as the animal ages seems to be related to the normal function of the adaptive immune response (Jeklova et al., 2007b). Moreover, most of the IEL in the appendix are CD8+ regulatory T cells important to control inflammation and maintain immune tolerance (Kooij et al. 2016). The observed increase in CD8+ T lymphocytes with age is in agreement with a significant increase in IL-10 expression together with a down-regulation of the chemokyne IL-8. Both interleukins participate in the control of lymphocyte-mediated inflammatory responses, i.e. IL-10 attract CD8+ T lymphocytes and inhibits the CD4+ T lymphocyte migration by an inhibitory effect on IL-8 (Jinquan et al., 1993). The commensal microflora in the appendix seems to play an 
important role in developing and maintaining a normal immune function by a direct interaction with lymphocyte function (Kooij et al., 2016). It was also noticeable the significant increase of IL-2 and IL-6 expression at weaning decreasing thereafter. This cytokine expression pattern at weaning was also observed by Vázquez et al. (2000) in mice, who reported a significant increase of IL-2, IL-6 and IL-10 in small intestine lamina propria total lymphocytes after weaning. The exposure to food antigens together with changes on gut microbiota results in a transient Th1 vs. Th2 balanced cytokine profile that helps the GALT mature and differentiates (Vázquez et al., 2000). Dietary Gln fed to 25d old rabbits significantly upregulated IL-2 and IL-10 and downregulated IL-6 expression. The concentration of extracellular Gln has been shown to increase IL-2 production and signaling in $\mathrm{T}$ lymphocytes (Newsholme, 2001). Also, in IL-1bstimulated duodenal biopsies the addition of Gln significantly increased IL-10 expression and reduced that of IL-6 and IL-8 (Coëffier, 2003). Given the important role of IL-2 in regulatory $\mathrm{T}$ cell homeostasis and function (Antony et al., 2006) it is plausive that the cytokine profile observed in our study is the result of a more moderate and balanced Th1Th2 response at weaning in rabbits fed the Gln supplemented diets. In contrast, Arg was shown to be more reactive at $6 \mathrm{~d}$ of age displaying a pro-inflammatory profile with increasing IL-8 and IL-6 expression in the appendix. In early weaned piglets Tan et al. (2009) reported a positive effect of dietary Arg by enhancing cellular and humoral immunity. They observed lower IL-8 serum concentrations but higher IL-8 gene expression in the piglet spleen with no significant changes on IL-6 concentration or expression. Arginine derived NO might enhance the immune response by means of increase lymphocyte proliferation, and macrophage and natural killer activity (Suchner et al., 2002). However, NO overproduction can also produce intestinal mucosa injury and dysfunction (Suchner et al., 2002). Moreover, NO production seems to be of relevance to control intestinal epithelial injury and restitution in neonatal necrotizing enterocolitis (Chokshi et al., 2008).

In conclusion, despite a lack of effect on performance and mortality the inclusion of $0.4 \%$ Gln has a positive effect by maintaining intestinal villous height and inducing a cytokine profile with a more moderate and balanced Th1-Th2 response at weaning. The supplementation with Arg or Arg+Gln at the selected doses in this study did not report any beneficial effect on the analyzed variables. 
Table 1. Primers for PCR amplification.

\begin{tabular}{lccc}
\hline Gene & GenBank & Sense primer & Antisense primer \\
\hline HPRT $^{1}$ & M31642 & 5'-TGATAGATCCATTCCTATGACTGTAGA-3' & 5'-GGGTCCTTTTCACCAGCAG-3' \\
GADPH & AB231852 & 5'-GGG CGT GAA CCA CGA GAA- 3' & 5'-GCC GAA GTG GTC GTG GAT-3' \\
IL-10 & D84217 & 5'-GAGAACCACAGTCCAGCCAT-3' & 5'-CATGGCTTTGTAGACGCCTT-3' \\
IL-6 & DQ680161 & 5'-GAGCATCCTGGAGACCATCAA-3' & 5'-CCAGTGCCTCCTTTCTGTTCA-3' \\
IL-8 & Ensembl $^{3}$ & 5'-GCAACCTTCCTGCTCTCTCTGA-3' & 5'-CACTGGCATCGAAGCTCTGTAC-3' \\
IL-2 & Ensembl $^{4}$ & 5'-CAAACTTTCCAGGATGCTCACA-3' & 5'-GAGGTTTGAGTTCTTCTTCTAGACACTGA-3'
\end{tabular}

${ }^{1}$ Godornes et al., 2008. ${ }^{2}$ Chamorro et al., 2010. ${ }^{3}$ Rabbit Ensembl ENSOCUG0000001 1835. ${ }^{4}$ Rabbit Ensembl ENSOCUT00000010098. 
Table 2. Effect of arginine and glutamine supplementation on finishing performance and mortality.

\begin{tabular}{|c|c|c|c|c|c|c|c|c|c|c|}
\hline & \multicolumn{4}{|c|}{ Diets $^{1}$} & \multicolumn{3}{|c|}{ SEM } & \multicolumn{3}{|c|}{$\mathrm{P}$-value } \\
\hline & $\mathrm{C}$ & Arg & Gln & Arg+Gln & Arg & Gln & Arg $\times$ Gln & Arg & Gln & Arg $\times$ Gln \\
\hline Arginine & 0 & 0.4 & 0 & 0.4 & & & & & & \\
\hline Glutamine & 0 & 0 & 0.4 & 0.4 & & & & & & \\
\hline $\mathrm{N}^{2}$ & 39 & 46 & 45 & 47 & & & & & & \\
\hline Body weight $25 \mathrm{~d}^{3}$ & 386 & 386 & 395 & 393 & 8.80 & 8.80 & 12.4 & 0.96 & 0.51 & 0.95 \\
\hline Body weight $35 \mathrm{~d}^{3}$ & 725 & 745 & 762 & 723 & 19.7 & 19.7 & 27.8 & 0.74 & 0.79 & 0.30 \\
\hline Weight gain, $\mathrm{g} / \mathrm{d}^{3}$ & 31.3 & 33.4 & 32.7 & 32.3 & 0.84 & 0.84 & 1.18 & 0.48 & 0.87 & 0.30 \\
\hline Feed intake, $\mathrm{g} / \mathrm{d}^{3}$ & 43.7 & 46.6 & 45.1 & 44.5 & 1.13 & 1.13 & 1.59 & 0.48 & 0.81 & 0.28 \\
\hline Feed efficiency, $\mathrm{g} / \mathrm{g}^{3}$ & 0.711 & 0.719 & 0.732 & 0.727 & 0.011 & 0.011 & 0.016 & 0.92 & 0.38 & 0.69 \\
\hline Mortality & 3.57 & 2.48 & 0.90 & 2.36 & - & - & - & 0.31 & 0.66 & 0.27 \\
\hline
\end{tabular}

${ }^{1} \mathrm{C}=$ control diet; $\mathrm{Arg}=0.4 \%$ arginine dietary supplementation; $\mathrm{Gln}=0.4 \%$ glutamine dietary supplementation; Arg $+\mathrm{Gln}=0.4 \%$ arginine $+0.4 \%$ glutamine supplementation. ${ }^{2} \mathrm{~N}=$ number of cages $\left(2-3\right.$ rabbits/cage). ${ }^{3} \mathrm{~N}$ (rabbits/diet): $\mathrm{C}=112, \mathrm{Arg}=121, \mathrm{Gln}=111$ and $\mathrm{Arg}+\mathrm{Gln}=127$. 
Table 3. Effect of dietary arginine and glutamine supplementation of primiparous rabbit does on mesenteric lymph nodes (MLN) microbiota of 6-d suckling kits. Values expressed as $\operatorname{Ln}$ (forming colonies unit/mg MLN) ${ }^{1}$

\begin{tabular}{|c|c|c|c|c|c|c|c|}
\hline \multirow[b]{3}{*}{ Arcinine } & \multicolumn{4}{|c|}{ Diets $^{2}$} & \multicolumn{3}{|c|}{ P-value } \\
\hline & $\mathrm{C}$ & Arg & Gln & Arg+Gln & Arg & Gln & ArgxGln \\
\hline & 0 & 0.4 & 0 & 0.4 & & & \\
\hline Glutamine & 0 & 0 & 0.4 & 0.4 & & & \\
\hline $\mathrm{N}$ & 6 & 6 & 6 & 6 & & & \\
\hline Total aerobes & $4.47 \pm 1.37$ & $7.02 \pm 0.38$ & $2.65 \pm 3.40$ & $2.59 \pm 3.50$ & 0.65 & 0.091 & 0.64 \\
\hline Facultative aerobes & $4.61 \pm 1.42$ & $7.11 \pm 0.41$ & $2.82 \pm 3.49$ & $2.45 \pm 4.19$ & 0.73 & 0.10 & 0.63 \\
\hline Total anaerobes & $8.65 \pm 0.50$ & $7.55 \pm 0.88$ & $6.19 \pm 1.73$ & $7.63 \pm 0.84$ & 0.87 & 0.22 & 0.19 \\
\hline
\end{tabular}

${ }^{1}$ Values expressed as Ln (forming colonies unit/mg MLN) \pm standard error. ${ }^{2} \mathrm{C}=$ control diet; $\operatorname{Arg}=0.4 \%$ arginine dietary supplementation; Gln $=0.4 \%$ glutamine dietary supplementation; $\operatorname{Arg}+\mathrm{Gln}=0.4 \%$ arginine $+0.4 \%$ glutamine supplementation . 
Table 4. Effect of arginine and glutamine supplementation on intestinal morphology.

\begin{tabular}{|c|c|c|c|c|c|c|c|c|c|c|c|c|c|c|c|c|}
\hline \multirow[b]{4}{*}{ Arginine } & \multicolumn{4}{|c|}{ Diets $^{1}$} & \multicolumn{3}{|c|}{ Age } & \multicolumn{5}{|c|}{ SEM } & \multicolumn{4}{|c|}{ P-value ${ }^{3}$} \\
\hline & $\mathrm{C}$ & Arg & Gln & $\mathrm{Arg}+\mathrm{Gln}$ & \multirow[t]{2}{*}{6} & 25 & 35 & \multirow{2}{*}{$\begin{array}{l}\text { Arg } \\
\text { and } \\
\text { Gln }\end{array}$} & \multirow[t]{2}{*}{$\operatorname{Arg} \times \mathrm{Gln}$} & \multirow[t]{2}{*}{ Age } & \multirow{2}{*}{$\begin{array}{c}\text { Arg } \times \text { Age } \\
\text { and } \\
\text { Gln } \times \text { Age }\end{array}$} & \multirow[t]{2}{*}{ Arg $\times$ Gln $\times$ Age } & \multirow[t]{2}{*}{ Arg } & \multirow[t]{2}{*}{ Gln } & \multirow[t]{2}{*}{ Arg $\times$ Gln } & \multirow[t]{2}{*}{ Age } \\
\hline & & & & & & & & & & & & & & & & \\
\hline & 0 & 0.4 & 0 & 0.4 & & & & & & & & & & & & \\
\hline Glutamine & 0 & 0 & 0.4 & 0.4 & & & & & & & & & & & & \\
\hline $\mathrm{N}$ & 31 & 32 & 32 & 32 & 48 & 40 & 39 & & & & & & & & & \\
\hline Villous height, $\mu \mathrm{m}$ & 609 & 580 & 577 & 575 & $620^{\mathrm{b}}$ & $510^{\mathrm{a}}$ & $626^{\mathrm{b}}$ & 13.6 & 19.2 & 16.6 & 23.5 & 33.2 & 0.44 & 0.34 & 0.48 & $<0.001$ \\
\hline Crypt depth, $\mu \mathrm{m}$ & 68.5 & 67.4 & 67.8 & 66.4 & $38.1^{\mathrm{a}}$ & $80.2^{b}$ & $84.2^{\mathrm{c}}$ & 0.71 & 1.01 & 0.87 & 1.23 & 1.74 & 0.21 & 0.42 & 0.86 & $<0.001$ \\
\hline Ratio villous/crypt & 10.2 & 10.0 & 9.94 & 9.96 & $16.3^{\mathrm{c}}$ & $6.36^{\mathrm{a}}$ & $7.38^{\mathrm{b}}$ & 0.22 & 0.31 & 0.27 & 0.38 & 0.53 & 0.76 & 0.61 & 0.71 & $<0.001$ \\
\hline Goblet cells, n\%/villi & 13.7 & 12.8 & 12.7 & 12.7 & $2.94^{\mathrm{a}}$ & $14.5^{\mathrm{b}}$ & $21.6^{c}$ & 0.38 & 0.53 & 0.46 & 0.65 & 0.92 & 0.41 & 0.30 & 0.42 & $<0.001$ \\
\hline $\begin{array}{l}\text { Mucose protein, } \mathrm{mg} / \mathrm{g} \text { of } \\
\text { tissue }^{2}\end{array}$ & 103 & 105 & 102 & 105 & - & 102 & 106 & 2.80 & 3.96 & 2.79 & 3.95 & 5.59 & 0.51 & 0.86 & 0.80 & 0.36 \\
\hline $\begin{array}{l}\text { Sucrose activity, } \mu \mathrm{mol} \text { of } \\
\text { glucose/mg of protein }{ }^{2}\end{array}$ & 390 & 386 & 314 & 352 & - & 116 & 605 & 37.8 & 53.4 & 37.7 & 53.4 & 75.5 & 0.76 & 0.31 & 0.70 & $<0.001$ \\
\hline
\end{tabular}


Table 5. Effects of the experimental diets and age on lymphocyte proportions in the appendix of rabbits.

\begin{tabular}{|c|c|c|c|c|c|c|c|c|c|c|c|c|c|c|c|c|}
\hline \multirow{4}{*}{$\begin{array}{l}\text { Arginine } \\
\text { Glutamine }\end{array}$} & \multicolumn{4}{|c|}{ Diets } & \multicolumn{3}{|c|}{ Age } & \multicolumn{5}{|c|}{ SEM } & \multicolumn{4}{|c|}{ P-value ${ }^{3}$} \\
\hline & $\mathrm{C}$ & Arg & Gln & Arg+Gln & 6 & 25 & 35 & $\begin{array}{l}\text { Arg } \\
\text { and } \\
\text { Gln }\end{array}$ & $\operatorname{Arg} \times$ Gln & Age & $\begin{array}{c}\text { Arg } \times \text { Age } \\
\text { and } \\
\text { Gln } \times \text { Age }\end{array}$ & $\operatorname{Arg} \times \operatorname{Gln} \times$ Age & Arg & Gln & Arg $\times$ Gln & Age \\
\hline & 0 & $\overline{0.4}$ & 0 & 0.4 & & & & & & & & & & & & \\
\hline & 0 & 0 & 0.4 & 0.4 & & & & & & & & & & & & \\
\hline $\mathrm{N}$ & 14 & 14 & 14 & 14 & 20 & 20 & 17 & & & & & & & & & \\
\hline $\mathrm{CD} 45^{+} \mathrm{CD}^{+2}$ & 30.3 & 29.1 & 31.8 & 35.7 & 36.3 & 26.3 & 32.7 & 3.79 & 5.35 & 4.64 & 6.56 & 9.27 & 0.79 & 0.45 & 0.65 & 0.30 \\
\hline $\mathrm{CD} 45^{+} \mathrm{CD} 4^{+2}$ & 19.4 & 20.6 & 23.7 & 24.8 & 23.2 & 13.6 & 29.5 & 3.85 & 5.44 & 4.71 & 6.66 & 9.41 & 0.84 & 0.44 & 0.99 & 0.065 \\
\hline $\mathrm{CD} 45^{+} \mathrm{CD}^{+2}$ & 16.1 & 17.2 & 20.2 & 20.7 & 15.8 & 12.4 & 27.5 & 4.08 & 5.77 & 4.99 & 7.06 & 9.97 & 0.89 & 0.52 & 0.96 & 0.099 \\
\hline
\end{tabular}

${ }^{1} \mathrm{C}=$ control diet; $\mathrm{Arg}=0.4 \%$ arginine dietary supplementation; Gln = 0.4\% glutamine dietary supplementation; Arg+Gln $=0.4 \%$ arginine $+0.4 \%$ glutamine supplementation.

$2 \%$ of total lymphocytes. ${ }^{3}$ No significant differences $(\mathrm{P} \geq 0.84)$ were found when the interaction Arg $\times$ Age, Gln $\times$ Age and Arg $\times$ Gln $\times$ Age were analyzed. 


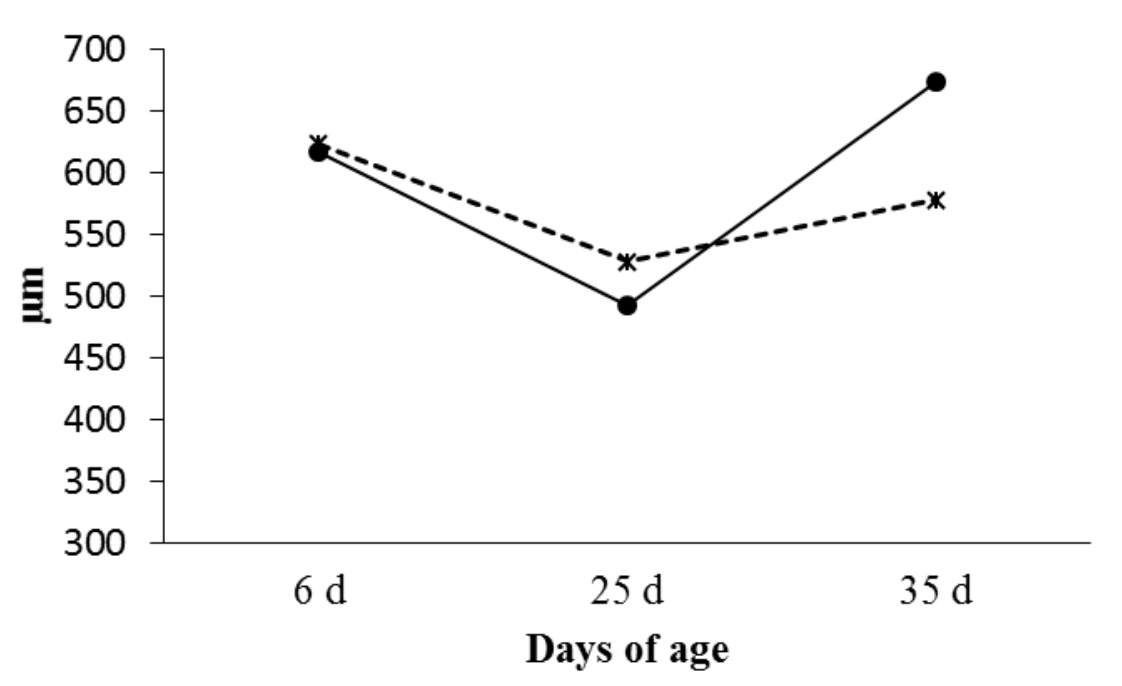

Figure 1. Effect of rabbit age and glutamine supplementation $(\mathrm{g} \ln 0 \bullet$ and gln $0.4 *$ ) on jejunal villous height. $\mathrm{P}=0.019$ 


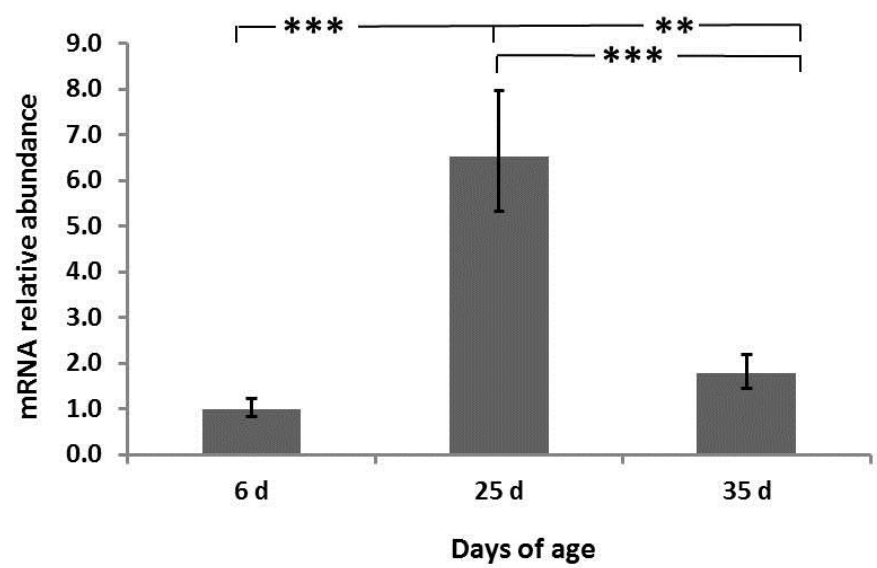

A)

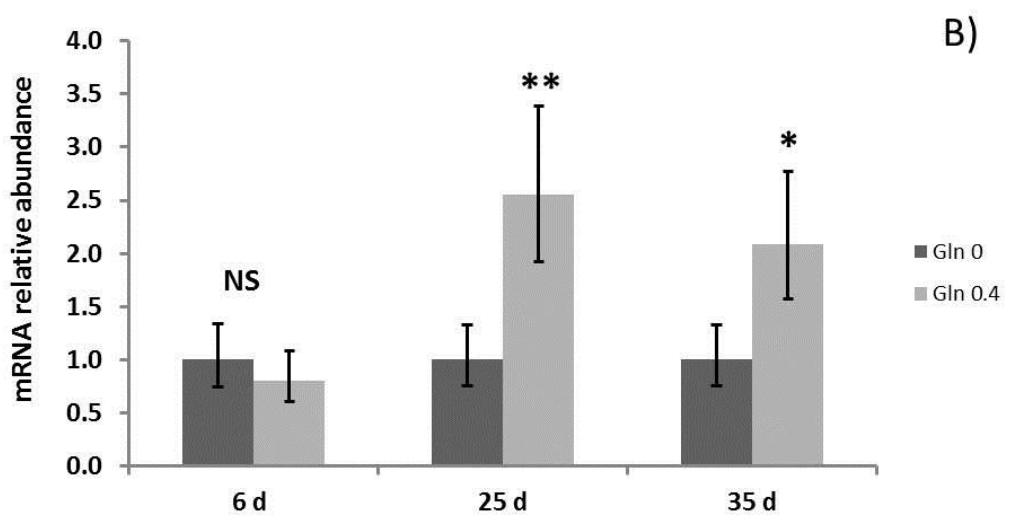

Figure 2. Interleukin (IL) 2 mRNA expression in intraepithelial lymphocytes isolated from rabbit Appendix. A) Relative gene expression values are fold change of 25 and 35 $\mathrm{d}$ relative to $6 \mathrm{~d}$ old rabbits set to be 1.0. B) Relative gene expression values are fold change of rabbits fed Gln 0.4 diets relative to no Gln supplemented diets set to be 1.0. Bars indicate the $95 \%$ confidence interval (Fold change up - Fold change low). (*: P < $0.05 ; * *: \mathrm{P}<0.01 ; * * *: \mathrm{P}<0.001)$. 

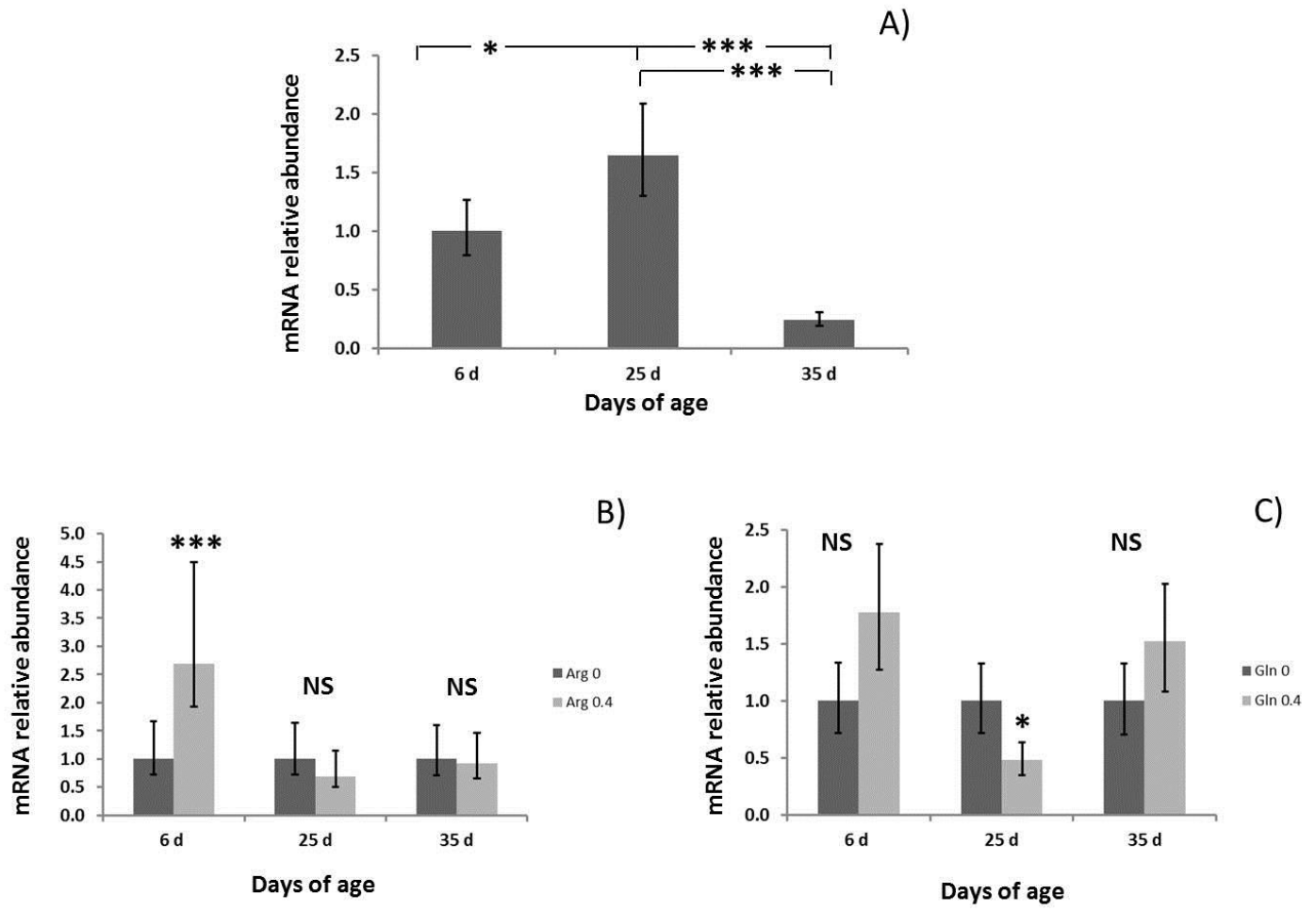

Figure 3. Interleukin (IL) 6 mRNA expression in intraepithelial lymphocytes isolated from rabbit Appendix. A) Relative gene expression values are fold change of 25 and 35 $\mathrm{d}$ relative to $6 \mathrm{~d}$ old rabbits set to be 1.0. B) Relative gene expression values are fold change of rabbits fed Arg 0.4 diets relative to no Arg supplemented diets set to be 1.0. C) Relative gene expression values are fold change of rabbits fed Gln 0.4 diets relative to no Gln supplemented diets set to be 1.0. Bars indicate the 95\% confidence interval (Fold change up - Fold change low). (*: $\mathrm{P}<0.05 ; * * *$ : $<0.001)$. 

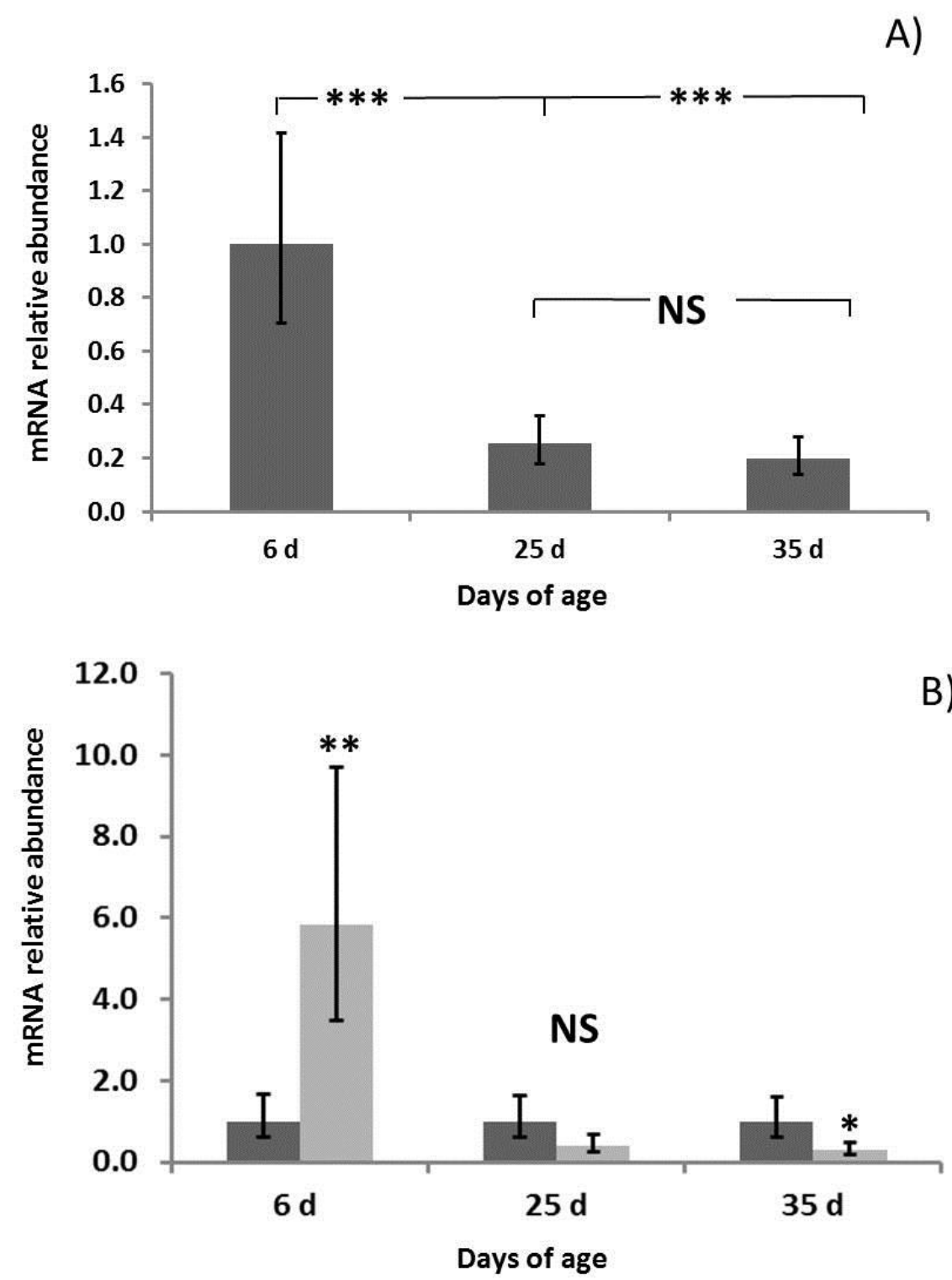

Figure 4. Interleukin (IL) $8 \mathrm{mRNA}$ expression in intraepithelial lymphocytes isolated from rabbit Appendix. A) Relative gene expression values are fold change of 25 and 35 $\mathrm{d}$ relative to $6 \mathrm{~d}$ old rabbits set to be 1.0. B) Relative gene expression values are fold change of rabbits fed Gln 0.4 diets relative to no Gln supplemented diets set to be 1.0. Bars indicate the $95 \%$ confidence interval (Fold change up - Fold change low). (*: P < $0.05 ; * *$ P $<0.01 ; * *: \mathrm{P}<0.001)$. 


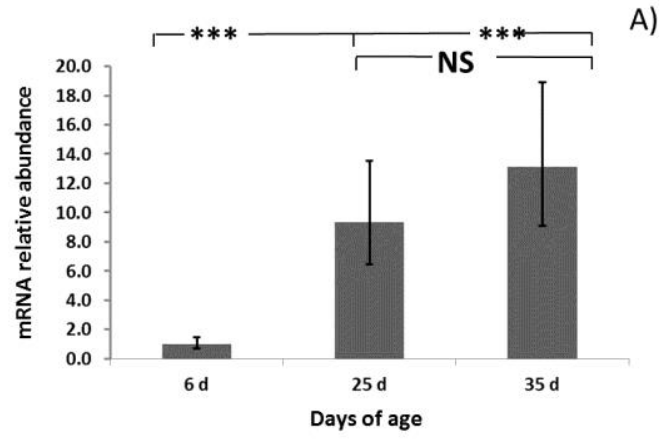

B)

C)
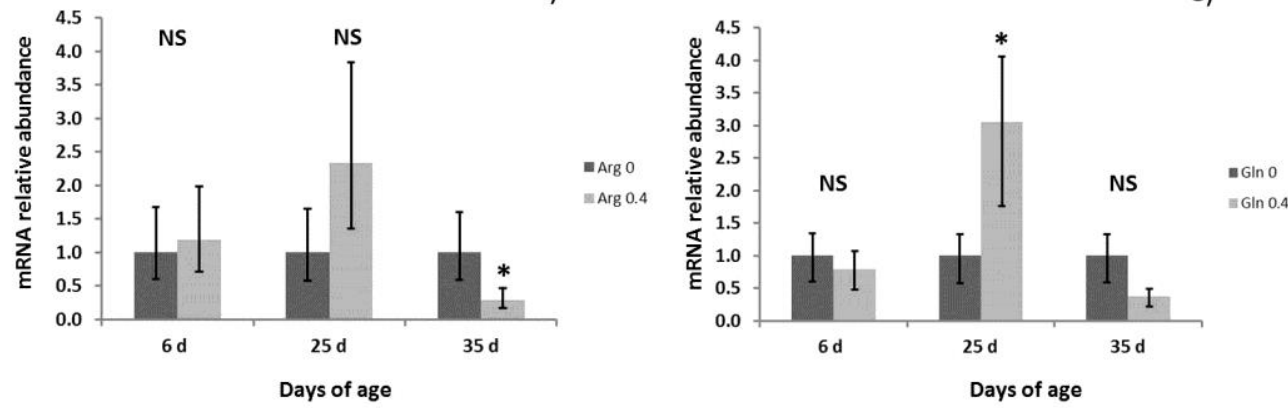

Figure 5. Interleukin (IL) 10 mRNA expression in intraepithelial lymphocytes isolated from rabbit Appendix. A) Relative gene expression values are fold change of 25 and 35 $\mathrm{d}$ relative to $6 \mathrm{~d}$ old rabbits set to be 1.0. B) Relative gene expression values are fold change of rabbits fed Arg 0.4 diets relative to no Arg supplemented diets set to be 1.0. C) Relative gene expression values are fold change of rabbits fed Gln 0.4 diets relative to no Gln supplemented diets set to be 1.0. Bars indicate the 95\% confidence interval (Fold change up - Fold change low). (*: $\mathrm{P}<0.05 ; * * *$ : $\mathrm{P}<0.001)$. 
Chapter 4

Dietary soluble fibre level and n-6/n-3 fatty acid ratio 



\subsection{Effect of dietary soluble fibre level and n-6/n-3 fatty acid ratio on the performance of rabbit does and their litters during the first four lactations.}

\subsubsection{Introduction.}

The increase of soluble fiber in diets for rabbits, using sugar beet pulp in the diet, improves the health status of young rabbits after weaning (Trocino et al., 2013a). It exerts positive effects on intestinal microbiota, immune response, mucosa functionality, growth performance and mortality (Gómez-Conde et al., 2007). However, the increase of soluble fiber in high insoluble fiber diets for rabbit does reduced their feed and DE intake, milk production and consequently the weight of kits at weaning (Martínez-Vallespín et al., 2011). These effects might be related to the cecal filling effect produced by the high dietary NDF level and/or the inclusion of sugar beet pulp (Carabaño et al., 1997) that might limit both feed and DE intake (García et al., 2002).

The inclusion of n-3 fatty acids might enhance rabbit health and productivity, although there are wide variations in the results obtained and no defined requirements or recommendations. The reduction of the dietary n-6/n-3 fatty acid ratio maintaining the same fat level, from 4.1 to 1.0 , using extruded linseed increased milk fat content of rabbit does and reduced kit mortality after weaning (Maertens et al., 2005). The reduction of $n-$ 6/n-3 ratio from 7.3 to 2.2 using salmon oil tended to increase kit weight and survival rate at birth (Rebollar et al., 2014), although the supplementation with marine algae PUFA impaired kit weight at birth and at weaning (Mordenti et al., 2010). This situation is similar to that found with sow productivity where the main positive and consistent effect of n-3 fatty acid supplementation was to improve piglet vitality (reviewed by Thange and De Smet, 2013). However, a positive effect of linseed oil supplementation on sow prolificacy was recently reported (Tanghe et al., 2014).

The aim of this work is to study the long-term effect of combining two levels of soluble fiber (at a lower NDF level than those previously studied) with two n-6/n-3 fatty acids ratio on the productivity of rabbit does and their litters along four parturitions and on milk composition. This design allow to study the potential additive effect of soluble fiber combined with a reduction of the n-6/n-3 fatty acid ratio that is unexplored in rabbits. 


\subsubsection{Materials and methods.}

\subsubsection{Experimental diets.}

Four diets in a $2 \times 2$ factorial arrangement were used with two levels of soluble fiber (7.8 vs. 13.0, on DM basis) and two different n-6/n-3 fatty acids ratio (13.4/1 vs. 3.5/1. Table 1). A control diet was formulated to meet nutrient requirements of rabbit does (De Blas and Mateos, 2010) with low soluble fiber level and high n-6/n-3 fatty acids ratio (LSF_Hn-6/n-3). The n-6/n-3 fatty acid ratio was selected considering that in rabbit diets with low alfalfa hay content $(<20 \%)$ and no added fat this ratio is usually above 15 (Santomá et al., 1987). The increase of soluble/fermentable fiber was obtained by replacing wheat straw and bran from control diet by sugar beet pulp (HSF_Hn-6/n-3). The level of inclusion of sugar beet pulp was maximized in order to obtain the highest dietary soluble fiber content, but under the threshold of $20 \%$ to limit the potential reduction of ADFI (Carabaño et al., 1997). In these two diets, the n-6/n-3 fatty acids ratio was increased by replacing high oleic sunflower oil and part of the standard sunflower oil by linseed oil (LSF_Ln-6/n-3 and HSF_Ln-6/n-3). It resulted in the replacement of oleic acid by linolenic acid, maintaining constant linoleic acid (Table 2). Levels of crude protein and NDF were 16.4 and $30.9 \%$ DM respectively, while the level of starch content was higher in low soluble fiber diets (22.4 vs. $18.3 \%$ DM).

\subsubsection{Lactation trial.}

Ninety six nulliparous $130 \mathrm{~d}$ old rabbit does New Zealand White $\times$ Californian (line V from UPV, Spain) were randomly assigned to the four treatments (24 rabbit does/diet) one week before the first artificial insemination. Rabbit does weighted on average $3.9 \pm$ $0.2 \mathrm{~kg} \mathrm{BW}$ and their body composition and energy content was (g/kg BW): $595 \pm 17.1$ moisture, $177 \pm 3.9$ protein, $157 \pm 16.8$ fat, $30.6 \pm 0.9$ ash and $11.4 \pm 0.7 \mathrm{MJ}$ gross energy (mean \pm standard deviation). After birth, does were inseminated $11 \mathrm{~d}$ after parturition corresponding to a theoretical kindling-to-kindling interval of $42 \mathrm{~d}$ and the weaning was at $25 \mathrm{~d}$ of lactation. Adoptions were made after parturition among rabbit does belonging to the same diets resulting an average litter size of $10.5 \pm 1.8$ kits. In order to synchronize oestrus, $48 \mathrm{~h}$ before insemination, the does were injected 25 IU of eCG (Segiran, Lab. Ovejero, León) (Rebollar et al., 2006). The day of insemination, does received an intramuscular injection of $1 \mu \mathrm{g}$ of buserelin Suprefact ${ }^{\circledR}$ (Hoechst Marison Roussel, S.A., Madrid). Buserelin is a Gonadotropin-releasing hormone agonist (GnRH agonist) used to 
induce ovulation in rabbit does (Quintela et al., 2004). The semen came from rabbit males of the R line (Universidad Politécnica de Valencia, Spain). Rabbit does that failed to get pregnant in two consecutive inseminations were excluded from the experiment.

Experimental period begun at first insemination and finished at weaning of the fourth cycle of inseminations (at the end of the fourth lactation of rabbit does that got pregnant in each insemination). Live weight, feed intake, reproductive traits and body composition was recorded at insemination, just after parturition and at weaning, and only rabbit does that completed at least two lactations were considered in the analysis. The bioelectrical impedance analysis (BIA) technique was used to determine the chemical body composition and energy content of rabbit does (Nicodemus et al., 2009; Pereda, 2010). Measurements of resistance and reactance were taken in rabbit does with a body composition analyzer (Model Quantum II, RJL Systems, Detroit, MI, USA) few hours after parturition, at insemination and at weaning (always after suckling), according to Romero et al. (2011). Multiple regression equations according to Nicodemus et al. (2009) were used to estimate water, protein, ash, fat and energy proportions with respect to the body weight of rabbit does. Fertility was expressed as 100/number of scheduled inseminations (every 42 days) performed until fertile kindling. Prolificacy (total number of rabbits born alive and dead) and mortality of rabbit does were also recorded. Mortality of young rabbits was recorded daily during lactation and was calculated as the percentage of rabbits dead with respect to the number of rabbits per litter once homogenized, using the litter as experimental unit. Milk iproduction was estimated daily from weight loss of does during suckling (10 min, once a day). Litters were moved to another cage at $20 \mathrm{~d}$ of age. They were offered ad libitum the same feed as their mothers and water, and suckled once a day for 10 min until weaning age ( $25 \mathrm{~d}$ ). One day after weaning, in vivo body and carcass chemical composition and energy content was estimated using the bioelectrical impedance analysis (BIA) technique in 40 rabbits/diet from this group, weaned from multiparous does and weighing $467 \pm 84 \mathrm{~g}$. Measurements of resistance and reactance were taken in rabbits with a body composition analyzer (Model Quantum II, RJL Systems, Detroit, MI, USA). Multiple regression equations according to Saiz et al. (2013a, 2013b and 2017) were used to estimate water, protein, ash, fat and energy proportions both in the body and in the carcass.

During the first gestation until $14 \mathrm{~d}$ before parturition, rabbit does were restricted to approximately $150 \mathrm{~g} / \mathrm{d}$ but afterwards diets were offered ad libitum along the 
experiment. Only does that failed to get pregnant were also restricted between weaning and the next insemination.

\subsubsection{Milk composition trial.}

A total of 36 rabbit does (9/diet) weighing $4.30 \pm 0.31 \mathrm{~kg}$ and with an average litter size of $10.6 \pm 0.87$ rabbits, were used to determine the milk composition of DM, ash, CP, fat and fatty acids profile. Five days after the first parturition, the area of the top mammary glands were shaved, disinfected with ethanol and $0.3 \mathrm{ml}$ oxitocin (Oxiton, Laboratorios Ovejero, León, Spain) were injected in the ear (i.v.) and 7-8 $\mathrm{ml}$ of milk were recollected in sterile tubes (scrapping the first jets). Samples were freeze-dried and stored frozen to determine milk composition.

\subsubsection{Digestibility trial.}

A total of 24 rabbit does (6/diet) weighing $4.04 \pm 0.21 \mathrm{~kg}$ and with an average litter size of $10.2 \pm 1.6$ kits were used to determine the apparent digestibility of DM, GE, CP and, total dietary fiber and NDF. Total faecal output was collected for each doe during four consecutive days (from day 15 to 19 of the third lactation). Feed intake (ad libitum access) was recorded during this period. Feces were stored at $-20{ }^{\circ} \mathrm{C}$ and later dried at $80^{\circ} \mathrm{C}$ for $48 \mathrm{~h}$ and ground to $1 \mathrm{~mm}$ for further analysis.

\subsubsection{Housing.}

Rabbit does were housed individually in flat-deck cages $(600 \times 500 \times 320 \mathrm{~mm})$ throughout the trial. An external nestbox $(355 \times 230 \times 360 \mathrm{~mm}$ high $)$ with wood shavings was provided three days before parturition. Housing conditions were controlled during the whole experimental period as follows: a 16-h light: 8-h dark cycle was established and temperature conditions were maintained between 18 and $24^{\circ} \mathrm{C}$. All the experimental procedures used were approved by the Animal Ethics Committee of the Universidad Politécnica de Madrid, and were in compliance with the Spanish guidelines for care and use of animals in research (BOE, 2013).

\subsubsection{Chemical analysis.}

Procedures of the AOAC (2000) were used to determine DM (method 934.01), ash (method 942.05), CP (method 968.06), ether extract (920.39), starch (amyloglucosidase$\alpha$-amylase method; method 996.11), and total dietary fibre (985.29). Sugars were 
analyzed according to Yemm and Willis (1954). Dietary NDF was determined using the filter bag system (Ankom Technology, New York) according to Mertens et al. (2002), and a thermo-stable amylase without any sodium sulphite added. It was corrected for its own ash and protein as indicated for total dietary fiber. Dietary ADF and ADL were analyzed according to Goering and Van Soest (1970), respectively. The soluble fiber was calculated by difference as TDF-NDF. Gross energy was determined by adiabatic calorimetry. Dietary fatty acids of experimental diets were extracted and quantified by the one-step procedure described by Sukhija and Palmquist (1988) in lyophilised samples. Gas chromatography analysis and conditions were as described elsewhere (Daza et al., 2007) using a 6890 Hewlett Packard gas chromatograph and a $30 \mathrm{~m} \times 0.3 \mathrm{~mm} \times 0.25 \mathrm{~m}$ cross-linked polyethylene glycol capillary column. Diets were analyzed in triplicate, and faeces in duplicate.

\subsubsection{Statistical analysis.}

The results obtained for faecal digestibility (DM, GE, CP, total dietary fiber, NDF, and soluble fiber) and milk composition (DM, ash, CP, fat, and fatty acid profile) were analyzed using a mixed model considering the level of soluble fibre, n-6/n-3 ratio and their interaction as the main sources of variation. Data from total removed, dead and culled does were analysed using logistic regression (GENMOD procedure of SAS, considering a binomial distribution) including the same variables in the model, and the results were transformed from the logit scale. Data from the lactation trial and body composition were analyzed in a factorial arrangement repeated for four parturitions by the mixed procedure of SAS (Littell et al., 1996) including in the model the level of soluble fibre, n-6/n-3 ratio, parity order and their interactions, and the rabbit doe as a random effect. The number of kits in each period was used as covariate in the model for milk production. Initial BW, body composition (protein, fat, moisture, ash) and energy content at $130 \mathrm{~d}$ of age were used as covariates in the model used for body composition and energy content along time. A compound symmetry structure was fitted as it showed the lowest value of the Schwarz Bayesian criterion (Littell et al., 1998). It assumes that measures over time on the same animals had the same variance and that all pairs of measures on the same animal had the same correlation. The data are presented as leastsquares means. When interactions were significant $(\mathrm{P}<0.05)$ comparisons among all the treatment means were made using a t-test. 


\subsubsection{Results.}

Treatments did not affect fecal DM and GE digestibility, but CP digestibility tended to decrease in HSF compared with LSF groups $(\mathrm{P}=0.072$; Table 3$)$ and led to a reduction of the digestible $\mathrm{CP} / \mathrm{DE}$ ratio (by $4 \% ; \mathrm{P}<0.001$ ). Fecal digestibility of total dietary fiber, NDF and soluble fiber increased in rabbit does fed HSF diets respect to does fed LSF diets (by 17, 12 and 22 percentage units, respectively; $\mathrm{P}<0.001$ ). The reduction of the $\mathrm{n}-$ 6/n-3 ratio reduced the total dietary fiber digestibility in rabbit does fed LSF diets but it had no effect in those fed HSF diets, resulting in an interaction soluble fiber $\times n-6 / n-3$ ratio $(P=0.043)$. A similar trend was observed for NDF digestibility $(P=0.091)$. Fecal digestibility of ether extract tended to be higher in does fed LSF_Hn-6/n-3 and HSF_Ln6/n-3 diets $(\mathrm{P}=0.092)$. Dry matter intake during the digestibility period was higher in rabbit does fed Ln-6/n-3 diets than in Hn-6/n-3 groups $(\mathrm{P}=0.038)$.

Feed intake during the first gestation (Artificial insemination1-parturition1) and during the average lactation period was lower in rabbits does fed with HSF compared to those fed LSF diets (by 10 and 6\%, respectively; $\mathrm{P} \leq 0.047$. Table 4). However, treatments had no effect on ADFI among parturitions $(P=0.16)$. It resulted in a minor effect on DE intake along the experiment (only a trend to reduce it in the first gestation in HSF groups), but in a reduction of digestible CP intake among parturitions (by 7\%) and throughout the experiment in does fed HSF diets $(\mathrm{P} \leq 0.005 ; \mathrm{P}=0.079$ for the weaning-parturition period). The dietary n-6/n-3 ratio had a minor influence on ADFI, DE and digestible CP intake. Feed intake from the third weaning to the fourth parturition tended to decrease in Ln-6/n-3 groups, leading to a reduction of DE and digestible CP intake in this period (interaction $\mathrm{n}-6 / \mathrm{n}-3$ ratio $\times$ parity; $\mathrm{P} \leq 0.054$; data not shown). On the opposite feed, $\mathrm{DE}$ and digestible CP intake tended to increase in Ln-6/n-3 groups at the beginning of lactation (parturition-insemination) from the second to the third and fourth parturitions ( $\mathrm{P}$ $\leq 0.081$; data not shown).

Total number of kits born (either alive or dead) and litter or average kit weight at birth were not affected by the treatments (Table 5). Once homogenized litter size the does fed the lower n-6/n-3 ratio (Ln-6/n-3 groups) showed a higher initial number of kits $(+0.5$; $\mathrm{P}=0.039)$ due to the artificial reduction of the standard error, whereas those fed HSF diets tended to reduce it $(\mathrm{P}=0.091)$. Rabbit does from LSF_Hn-6/n-3 and HSF_Ln-6/n3 tended to reduce gradually kit mortality during lactation from the first to the fourth 
lactation (14 to 0\%; Figure 1), whereas those fed LSF_Ln-6/n-3 and HSF_Hn-6/n-3 showed a constant mortality along lactations (10.5\% on average), resulting in an interaction soluble fiber $\times n-6 / n-3$ ratio $\times$ parity $(P=0.007)$. However, treatments had no effect on litter size at weaning $(\mathrm{P} \geq 0.29)$. The average weight of kits at weaning from LSF_Hn-6/n-3 and HSF_Ln-6/n-3 groups decreased by 6\% compared with those from the other two groups $(\mathrm{P}=0.030)$. Furthermore, only in the fourth lactation kit weight at 20 and $25 \mathrm{~d}$ and litter feed intake from 20 to $25 \mathrm{~d}$ was higher in LSF compared with HSF groups (data not shown; $\mathrm{P} \leq 0.047$ ). Feed efficiency of rabbit does did not differ among rabbit does fed different treatments $(\mathrm{P} \geq 0.11)$.

Weight of rabbit does at parturition and at weaning were not affected by the diet, but those fed Ln-6/n-3 diets tended to be heavier than Hn-6/n-3 group the day of insemination $(P=0.10$. Table 6$)$. Fertility averaged $94.4 \%$ and dietary treatments did not influence it $(\mathrm{P} \geq 0.34)$. The increase of soluble fiber in the diet, tended to reduce the milk production from 10 to $20 \mathrm{~d}$ of lactation $(\mathrm{P}=0.089)$, but had no effect on the total milk production $(\mathrm{P}=0.12)$. Treatments had no effect on body chemical composition and body energy content of rabbit does at parturition, artificial insemination and weaning (Table 7). Only at weaning was found a reduction of body protein from the first to the fourth weaning in rabbit does from all treatments but in those from LSF_Hn-6/n-3 group this value remained constant leading to an interaction among level of soluble fiber $\times n-6 / n-3$ fatty acid ratio $\times$ parity was $(\mathrm{P}=0.049$. Data not shown). The proportion of total removed does decreased in HSF respect to LSF groups (22.9 vs. 50.0\%; $\mathrm{P}=0.005)$, due to the trend to reduce the culled and dead rabbit does $(\mathrm{P} \leq 0.059$. Table 8$)$. The proportion of total removed does tended to decrease in LSF groups when the $n-6 / n-3$ ratio increased and in HSF diets when the $n-6 / n-3$ ratio decreased $(P=0.059)$. The causes of mortality were reproductive (mainly abortions), digestive troubles and other causes that could not be established.

The milk DM and CP contents did not differ among rabbit does fed different dietary treatments $(P \geq 0.13$. Table 9$)$. The reduction of the dietary $n-6 / n-3$ ratio increased the milk fat content by $12 \%(\mathrm{P}=0.031)$, with no effect of the level of soluble fiber. The proportion of milk odd fatty acids and SFA increased in rabbit does fed the HSF diets compared with those fed LSF diets (by 11 and 3\%, respectively; $\mathrm{P} \leq 0.037$ ), whereas the proportion of short and medium chain fatty acids tended also to increase in HSF groups $(\mathrm{P}=0.080)$. The dietary $\mathrm{n}-6 / \mathrm{n}-3$ fatty acid ratio had no effect on these proportions. 
However, the reduction of the dietary n-6/n-3 ratio reduced the milk C18:1n9 (by $19 \%$; $\mathrm{P}$ $<0.001$ ) and increased the $\mathrm{C} 18: 3 \mathrm{n} 3$ proportion (by 306\%; $\mathrm{P}<0.001$ ). The $\mathrm{C} 18: \ln 9$ and $\mathrm{C} 18: 3 \mathrm{n} 3$ milk concentrations were closely correlated to their concentrations in the diet $(\mathrm{r}$ $=0.95$ and $\mathrm{P}=0.046$ for $\mathrm{C} 18: 1 \mathrm{n} 9 ; \mathrm{r}=0.99$ and $\mathrm{P}=0.002$ for $\mathrm{C} 18: 3 \mathrm{n} 3)$. Dietary linolenic acid also was positively correlated with $\mathrm{C} 14: 4 \mathrm{n} 3, \mathrm{C} 20: 5 \mathrm{n} 3$ and $\mathrm{C} 22: \ln 9$ ( $\mathrm{r} \geq 0.98 ; \mathrm{P} \leq$ 0.022). The efficiency of $\mathrm{C} 18: 3 \mathrm{n} 3$ retention in milk was higher for rabbit does fed HSF diets $(P=0.002)$, especially when combined with a high n-6/n3 ratio (HSF_Hn-6/n-3 diet. $\mathrm{P}<0.05)$. The milk $\mathrm{C} 18: 2 \mathrm{n} 6$ proportion decreased by $4 \%$ in rabbit does fed HSF diets ( $\mathrm{P}$ $=0.025)$ and increased by $4 \%$ in does fed Ln- $6 / \mathrm{n}-3$ diets $(\mathrm{P}=0.022)$, but it did not correlate with the dietary concentration of C18:2n6. The efficiency of C18:2n6 retention in milk was higher for rabbit does fed Ln-6/n-3 diets ( $\mathrm{P}<0.001)$, and decreased especially in LSF_Hn-6/n-3 group ( $\mathrm{P}<0.05)$. Overall, the efficiency of C18:2n6 retention in milk was 12 percentage units higher (on average; $\mathrm{P}<0.001$ ) than for $\mathrm{C} 18: 3 \mathrm{n} 3$, and it increased with the higher dietary $n-6 / n-3$ ratio especially when combined with a low soluble fiber diet $(P<0.001)$. The reduction of the $n-6 / n-3$ ratio in the diet increased the milk concentrations of C18:4n3 (by 710\%), C20:3n3 (by 122\%), C20:4n3 (by 22\%) and $\mathrm{C} 20: 5 \mathrm{n} 3$ (by $105 \%)(\mathrm{P} \leq 0.027)$ and decreased $\mathrm{C} 20: \ln 9$ concentration $(\mathrm{P}=0.010)$. These changes were reflected in a reduction of the milk n-6/n-3 ratio and an increase of PUFA when the dietary n-6/n-3 ratio decreased $(\mathrm{P}<0.001)$, with no effect of the level of soluble fiber. These changes in milk composition had minor effects on the body and carcass composition of weaned rabbits (Table 10 ). The reduction of the $n-6 / n-3$ ratio slightly increased the body protein and moisture but decreased the carcass protein proportion, while the level of soluble fibre reduced minimally the body energy content.

The weight of rabbit does at parturition, their feed intake, DE and digestible $\mathrm{CP}$ intake, and milk production increased progressively from the first until the fourth parturition (Table 4 and 6; $\mathrm{P}<0.001$ ). Fertility rate was higher in the first and fourth parturition compared with the second and third ones $(\mathrm{P}<0.001)$. Total number kits born per litter and at weaning increased between the first and the second parturition, decreasing from the second to the fourth parturition (Table 5; $\mathrm{P}<0.008$ ). Weight of litter at birth and at weaning increased in the second parturition respect to the first parturition and remained constant in the following parturitions $(\mathrm{P}<0.001)$. However, average weight of kits at birth and at weaning increased from the first to the fourth parturition $(\mathrm{P}<0.001)$. Feed 
efficiency increased in the second and third parturition respect to the first parturition ( $\mathrm{P}$ $<0.001)$.

Body protein proportion at parturition increased in multiparous does compared to nulliparous does $(\mathrm{P}<0.001$. Table 7$)$, whereas no change was found for the fat content. At first insemination rabbit does had a lower body protein and higher body fat content than multiparous does $(\mathrm{P}<0.001)$, although body protein decreased at fourth parturition. At weaning the body protein remained constant until the fourth parturition where it decreased, whereas body fat content increased successively from the first to the fourth parturition $(\mathrm{P}<0.001)$. The temporal evolution with the productive/reproductive events (five reproductive cycles) of body composition, energy content and weight of all the rabbit does considered in this study is showed in Figure 1A (time effect: $\mathrm{P}<0.001$ for all traits). In Figure 1B is represented this evolution but only for rabbits does that had five successful and consecutive inseminations $(n=18)$. These highly productive rabbit does did not differ from the whole group in the initial body weight, protein, fat and energy content ( $\mathrm{P} \geq 0.26$. Figure $1 \mathrm{~A}$ and $1 \mathrm{~B})$. Highly productive primiparous does tended to mobilize a higher proportion of fat from the second insemination until the first weaning compared to the standard does $(\mathrm{P}=0.10)$.

\subsubsection{Discussion.}

Dietary soluble fiber has demonstrated to improve the intestinal health of young rabbits after weaning when they suffer of epizootic rabbit enteropathy (MartínezVallespín et al., 2011; Trocino et al., 2013a). The soluble fiber exert positive effects on the jejunal mucosa and on the ileal starch digestibility in young rabbits (Gómez-Conde et al., 2007) and increase the ileal flow of mucins in adult rabbits (Abad-Guamán et al., 2015), which might indicate a better gut barrier function in the small intestine. In this study, the increase of the level of soluble fiber also reduced the proportion of the rabbit does removed due to the trend to decrease of both the mortality and the culling rate, although the health of intestinal mucosa does not seem to be a key factor in adult animals. However, the higher fecal NDF and soluble fiber digestibility in rabbit does fed HSF diets might be related to this effect, because a higher amount of fermented fiber might promote a change in the intestinal microbiota profile. In fact, Delgado et al. (2015b) found that the fecal microbiota of these rabbit does differed according to the dietary soluble fiber content. 
The increase of soluble fiber affected negatively ADFI during the first pregnancy and along the lactation period, where ADFI is maximal, in spite of the level of sugar beet pulp inclusion was not high. This might be explained by the accumulation of digesta in the caecum when sugar beet pulp is included substituting other sources of fiber (Carabaño et al., 1997; Falcao-e-Cunha et al., 2004; Gómez-Conde et al., 2009) that reduce the rate of passage of the digesta through the gut (Gidenne et al., 1987). The reduction of ADFI in HSF groups did not affect DE intake, due to the increase of fiber digestibility, but reduced the digestible $\mathrm{CP}$ intake throughout the experiment. However, the performance of rabbit does fed HSF diets did not impair (milk production, litter size and weight at weaning, or body condition) although the initial litter size at the beginning of lactation (once homogenized) tended to be lower. In contrast, the substitution of sugar beet pulp for wheat in highly fibrous diets decreased ADFI, CP and DE intake in rabbit does leading to a reduction of milk production and litter weight at weaning (Martínez-Vallespín et al., 2011).

The reduction of the dietary n-6/n-3 fatty acid ratio did not influence the proportion of removed rabbit does and their performance (ADFI, DE and digestible CP intake, milk production, litter size and weight at birth and at weaning, and body condition). It indicates that there is no relevant and practical effect of $n-6 / n-3$ ratio on fetal development during pregnancy (prolificacy o average kit weight at birth). Only, the number of rabbits per litter at the beginning of the lactation increased, once homogenized the litters, due to the artificial reduction of the variability of this trait. It might suggest a potential minor effect of the reduction of this ratio on rabbit prolificacy, similar to that reported in sows (Tanghe et al., 2014), although it should be confirmed using a higher number of rabbit does.

The level of soluble fiber and the n-6/n-3 fatty acid ratio interacted and influenced the litter performance during lactation. The average growth rate of kits during lactation tended to impair with the reduction of n-6/n-3 ratio for HSF groups, whereas no effect was found in LSF groups. In contrast, the mortality during lactation of litters from LSF_Hn-6/n-3 and HSF_ Ln-6/n-3 groups was reduced along the successive lactations compared with the other two groups. There is no clear explanation for these effects, and they do not seem to be related to differences in milk production and/or composition or ADFI before weaning. Boudry et al. (2009) suggested that suckling piglets, from sows supplemented with linseed oil, would be less sensitive to stress or challenge involving mast cell degranulation. However, this would not explain these effects. The effect of the 
soluble fiber level and n-6/n-3 ratio on the fecal and milk microbial profile of rabbit does (from this experiment), respectively, might influence the microbial profile observed in the mesenteric lymph nodes of 5-d old kits and might be potentially behind these effects (Delgado et al., 2015b). In fact, the gut microbiota seem to play an important role in the interaction between dietary fermentable carbohydrates (fructooligosaccharides) and n-3 PUFA on growth rate or cecal weight in adult mice (Pachikian et al, 2011).

Both dietary factors, level of soluble fiber and n-6/n-3 fatty acid ratio, produced important changes in the fatty acid profile of milk, although they would not seem related to litter performance and survival as already commented. The dietary $n-6 / n-3$ ratio modified the major fatty acids with 18 carbon atoms or more, as expected, with a minor influence of soluble fiber on this fraction. Besides, the increase of the $n-6 / n-3$ ratio enhanced the milk C20:5n3 (EPA) content, confirming its capacity to elongate C18:2n3, although no DHA was detected. The n-6/n-3 fatty acid ratio increased in milk compared with that found in the experimental diets, especially in LSF_Ln-6/n-3 and HSF_Hn-6/n3 diets respect the other two diets (by 52 and 24\%, respectively). This effect is similar to that obtained previously by Castellini et al. (2004) and Volek et al. (2014), although other studies did not report it (Maertens et al., 2005). It might be partially explained by the higher milk retention efficiency of C18:2n6 compared with C18:3n3. These both effects might be mediated by microbial activity and the final microbiota-derived PUFA metabolites obtained (Druart et al., 2014). All these changes produced by the reduction of the dietary n-6/n-3 ratio on the milk fatty acid profile were accompanied by an increase of the milk fat level, in agreement with Maertens et al. (2005). There is no clear explanation for this effect, as there is no modification of DE intake or energy mobilization in this period. Only a positive correlation between the efficiency of $\mathrm{C} 18: 2 \mathrm{n} 6$ retention in milk and the milk fat content was found $(\mathrm{r}=0.59 ; \mathrm{P}<0.001)$.

In contrast, rabbit does fed HSF diets increased the proportion of milk odd-chain fatty acids that constitutes a minor proportion of milk fat, with no effect of the $n-6 / n-3$ ratio. Odd-chain fatty acids are synthetized by the intestinal microbiota through the elongation of propionate and valuate, minor volatile fatty acids derived from microbial fermentation in rabbits, and in ruminants are used as a biomarker of ruminal function (Vlaeminck et al., 2006). In this study, the sum of all milk odd-chain fatty acids tended to be positively correlated with the fecal digestible total dietary fiber $(\mathrm{r}=0.91 ; \mathrm{P}=0.089)$, that is another indicator of microbial activity although it would not represent the whole 
organic matter fermented (Abad-Guamán et al., 2015). These fatty acids would be transferred to milk through the digestion of microbial fat recycled through cecotrophy or by the direct transference of intestinal bacteria to the milk (Donnet-Huhghes et al., 2010; Delgado et al., 2015b). The increase of soluble fiber also tended to increase the proportion of milk short and medium chain fatty acids, but it was not clearly correlated with digestible total dietary fiber $(r=0.89 ; \mathrm{P}=0.11)$, with no influence of $n-6 / n-3$ ratio. It is explained because short and medium fatty acids are mainly synthetized from glucose and acetate (Jones and Parker, 1981), and HSF diets supplied of higher digestible fiber content (and accordingly probably of acetic) but of a lower starch content). Dietary soluble fiber tended to increase the milk caprioic acid concentration that is a fatty acid with demonstrated in vitro antibacterial activity towards E. Coli (Marounek et al., 2003). This fatty acid combined with caprylic acid also reduced the post-weaning mortality in rabbits (Skrivanova and Marounek., 2006), although no direct effect of these fatty acid on kit health were observed in this experiment.

In conclusion, SF reduced the replacement rate of rabbit does with no effect of the n-6/n-3 ratio, while both dietary factors modified milk composition and fatty acid profile with minor influence on litter productivity. 
Table 1. Ingredient and chemical composition of experimental diets.

\begin{tabular}{|c|c|c|c|c|}
\hline \multirow{2}{*}{$\overline{\text { Item }^{1}}$} & \multicolumn{2}{|c|}{ Low soluble fibre } & \multicolumn{2}{|c|}{ High soluble fibre } \\
\hline & LSF_Hn-6/n-3 & LSF_Ln-6/n-3 & HSF_Hn-6/n-3 & HSF_Ln-6/n-3 \\
\hline \multicolumn{5}{|l|}{ Ingredient, (g/kg DM) } \\
\hline Wheat bran & 280 & 280 & 130 & 130 \\
\hline Wheat straw & 100 & 100 & 50.0 & 50.0 \\
\hline Beet pulp & 0.00 & 0.00 & 180 & 180 \\
\hline Wheat & 227 & 227 & 217 & 217 \\
\hline Dehydrated alfalfa & 150 & 150 & 150 & 150 \\
\hline Dehydrated alfalfa-Yb & 5.0 & 5.0 & 5.0 & 5.0 \\
\hline Soybean meal & 80.0 & 80.0 & 80.0 & 80.0 \\
\hline Sunflower meal & 99.7 & 99.7 & 129.7 & 129.7 \\
\hline High oleic sunflower oil & 8.50 & 0.00 & 8.50 & 0.00 \\
\hline Standard sunflower oil & 21.5 & 20.0 & 21.5 & 20.0 \\
\hline Linseed oil & 0.00 & 10.0 & 0.00 & 10.0 \\
\hline L-lysine $\mathrm{HCl}$ & 4.40 & 4.40 & 4.40 & 4.40 \\
\hline DL-methionine & 0.80 & 0.80 & 0.60 & 0.60 \\
\hline L-threonine & 3.10 & 3.10 & 3.20 & 3.20 \\
\hline Calcium carbonate & 12.0 & 12.0 & 7.0 & 7.0 \\
\hline Sodium chloride & 3.0 & 3.0 & 3.10 & 3.10 \\
\hline Calcium phosphate & 5.0 & 5.0 & 10.0 & 10.0 \\
\hline Mineral/vitamin premix ${ }^{2}$ & 5.0 & 5.0 & 5.0 & 5.0 \\
\hline \multirow{2}{*}{\multicolumn{5}{|c|}{$\begin{array}{l}\text { Analyzed chemical composition, } \mathrm{g} / \mathrm{kg} \\
\text { DM }\end{array}$}} \\
\hline & & & & \\
\hline DM & 908 & 906 & 908 & 910 \\
\hline Ash & 70.8 & 72.9 & 67.5 & 67.2 \\
\hline $\mathrm{CP}$ & 167 & 164 & 165 & 165 \\
\hline CP-Total dietary fiber & 92.9 & 98.7 & 96.5 & 97.8 \\
\hline CP-NDF & 58.3 & 57.0 & 78.6 & 78.6 \\
\hline Total dietary fiber & 391 & 380 & 442 & 438 \\
\hline NDF & 307 & 309 & 312 & 308 \\
\hline $\mathrm{ADF}$ & 165 & 167 & 185 & 187 \\
\hline ADL & 31.0 & 31.0 & 33.0 & 34.0 \\
\hline Soluble fiber & 84.0 & 71.9 & 130 & 130 \\
\hline Starch & 226 & 222 & 182 & 184 \\
\hline Ether extract & 53.8 & 49.1 & 48.7 & 50.0 \\
\hline Sugars & 79.9 & 82.3 & 81.7 & 84.4 \\
\hline GE, MJ/kg MS & 18.4 & 18.2 & 18.3 & 18.1 \\
\hline
\end{tabular}

${ }^{1}$ LSF_Hn-6/n-3 = Low soluble fibre_High n-6/n-3 fatty acid ratio; LSF_Ln-6/n-3 = Low soluble fibre_Low n6/n-3 fatty acid ratio; HSF_Hn-6/n-3 = High soluble fibre_High n-6/n-3 fatty acid ratio; HSF_Ln-6/n-3 = High soluble fibre_Low n-6/n-3 fatty acid ratio. ${ }^{2}$ Provided by Trouw Nutrition (Madrid, Spain). Mineral and vitamin composition (per kg of complete diet): $20 \mathrm{mg}$ of $\mathrm{Mn}$ as $\mathrm{MnO} ; 59.2 \mathrm{mg}$ of $\mathrm{Zn}$ as $\mathrm{ZnO} ; 10 \mathrm{mg}$ of $\mathrm{Cu}$ as $\mathrm{CuSO} 45 \mathrm{H} 2 \mathrm{O} ; 1.25$ $\mathrm{mg}$ of I as KI; $0.495 \mathrm{mg}$ of $\mathrm{Co}$ as $\mathrm{CoCO} 3 \mathrm{H} 2 \mathrm{O} \mathrm{H} 2 \mathrm{O} ; 76 \mathrm{mg}$ of $\mathrm{Fe}$ as FeCO3; $8375 \mathrm{UI}$ of vitamin A; $750 \mathrm{UI}$ of vitamin D3, $20 \mathrm{UI}$ of vitamin $\mathrm{E}$ as DL- $\alpha$-tocopherol acetate, $1.0 \mathrm{mg}$ of vitamin $\mathrm{K} ; 1.0 \mathrm{mg}$ of vitamin B1; $2 \mathrm{mg}$ of vitamin B2; $1 \mathrm{mg}$ of vitamin B6; $20 \mathrm{mg}$ of Niacin; $54.1 \mathrm{mg}$ of Betaine; 137,5 mg of Choline chloride; $66 \mathrm{mg}$ of robenidine; $50 \mathrm{mg}$ of ethoxyquin. 
Table 2. Fatty acid profile of experimental diets ( $\mathrm{g} / \mathrm{kg} \mathrm{DM})$.

\begin{tabular}{|c|c|c|c|c|}
\hline \multirow[b]{2}{*}{ Item $^{1}$} & \multicolumn{2}{|c|}{ Low soluble fibre } & \multicolumn{2}{|c|}{ High soluble fibre } \\
\hline & LSF_Hn-6/n-3 & LSF_Ln-6/n-3 & HSF_Hn-6/n-3 & HSF_Ln-6/n-3 \\
\hline Myristic, C14:0 & 2.20 & 2.70 & 2.60 & 3.50 \\
\hline Pentadecanoic, C15:0 & 0.90 & 0.90 & 1.10 & 1.40 \\
\hline Palmitic, C16:0 & 110 & 116 & 107 & 114 \\
\hline Palmitoleic, C16:1n7 & 1.90 & 1.50 & 1.60 & 1.60 \\
\hline Cis-7hexadecenoic, C16:1n9 & 1.80 & 2.10 & 1.50 & 1.60 \\
\hline Stearic, C18:0 & 29.8 & 32.0 & 31.7 & 33.3 \\
\hline Oleic, C18:1n9 & 303 & 201 & 314 & 201 \\
\hline Vaccenic, C18:1n7 & 6.60 & 7.00 & 6.70 & 7.50 \\
\hline Linoleic, C18:2n6 & 489 & 480 & 472 & 468 \\
\hline$\alpha$-Linolenic, C18:3n3 & 28.5 & 124 & 27.0 & 133 \\
\hline$\gamma$-Linolenic, C18:3n6 & 0.70 & 0.70 & 0.90 & 1.00 \\
\hline Stearidonic, C18:4n3 & 1.00 & 0.80 & 1.20 & 1.10 \\
\hline Arachidic, C20:0 & 4.10 & 4.10 & 4.50 & 4.60 \\
\hline Gondoic,C20:1n9 & 4.10 & 4.50 & 3.90 & 3.60 \\
\hline Dihomo- $\gamma$-linolenic,C20:3n6 & 0.00 & 1.50 & 1.40 & 1.80 \\
\hline Eicapentaenoic, C20:5n3 & 0.00 & 1.30 & 1.30 & 1.80 \\
\hline Erucic, C22:1n9 & 7.80 & 6.00 & 8.10 & 7.00 \\
\hline Unidentified & 7.80 & 13.6 & 13.4 & 13.4 \\
\hline SFA & 147 & 156 & 147 & 157 \\
\hline MUFA & 325 & 222 & 336 & 223 \\
\hline PUFA & 519 & 608 & 504 & 607 \\
\hline$n-6$ & 490 & 482 & 474 & 471 \\
\hline$n-3$ & 34.0 & 130 & 38.0 & 140 \\
\hline$n-6 / n-3$ & 144 & 37.1 & 125 & 33.6 \\
\hline
\end{tabular}

${ }^{1}$ LSF_Hn-6/n-3 = Low soluble fibre_High n-6/n-3 fatty acid ratio; LSF_Ln-6/n-3 = Low soluble fibre_Low n-6/n-3 fatty acid ratio; HSF_Hn-6/n-3 = High soluble fibre_High n-6/n-3 fatty acid ratio; HSF_Ln-6/n-3 $=$ High soluble fibre_Low $n-6 / n-3$ fatty acid ratio. 
Table 3. Effect of level of soluble fiber and n-6/n-3 fatty acids profile on feed intake and faecal apparent digestibility of nutrients in rabbit does.

\begin{tabular}{|c|c|c|c|c|c|c|c|c|c|}
\hline \multirow[b]{3}{*}{$\mathrm{N}$} & \multicolumn{4}{|c|}{ Diets $^{1}$} & \multicolumn{2}{|c|}{ SEM } & \multicolumn{3}{|c|}{ Parity order } \\
\hline & $\begin{array}{c}\text { LSF_Hn- } \\
6 / n-3\end{array}$ & $\begin{array}{c}\text { LSF_Ln- } \\
6 / n-3\end{array}$ & $\begin{array}{c}\mathrm{HSF}_{-} \mathrm{Hn}- \\
6 / \mathrm{n}-3\end{array}$ & $\begin{array}{c}\text { HSF_Ln- } \\
6 / n-3\end{array}$ & $\begin{array}{c}\text { SF and n-6/n- } \\
3\end{array}$ & $\begin{array}{c}\text { SF } \times n-6 / n- \\
3\end{array}$ & SF & $n-6 / n-3$ & $S F \times n-6 / n-3$ \\
\hline & 8 & 8 & 8 & 8 & & & & & \\
\hline DMI, g DM/d & 318 & 368 & 319 & 340 & 11.5 & 16.3 & 0.43 & 0.038 & 0.37 \\
\hline \multicolumn{10}{|l|}{ Fecal apparent digestibility, \% } \\
\hline $\mathrm{DM}$ & 62.3 & 61.4 & 62.6 & 64.0 & 0.85 & 1.21 & 0.23 & 0.83 & 0.34 \\
\hline GE & 62.7 & 60.7 & 62.4 & 63.3 & 0.86 & 1.21 & 0.34 & 0.64 & 0.25 \\
\hline $\mathrm{CP}$ & 69.5 & 69.2 & 65.9 & 66.6 & 1.17 & 1.65 & 0.072 & 0.90 & 0.76 \\
\hline Ether extract & 73.2 & 70.3 & 71.2 & 74.2 & 1.17 & 1.66 & 0.57 & 0.98 & 0.092 \\
\hline Total dietary fiber & $29.0^{\mathrm{b}}$ & $23.2^{\mathrm{a}}$ & $42.3^{c}$ & $43.8^{c}$ & 1.21 & 1.74 & $<0.001$ & 0.22 & 0.043 \\
\hline $\mathrm{NDF}$ & 24.3 & 20.0 & 33.1 & 35.4 & 1.31 & 1.85 & $<0.001$ & 0.60 & 0.091 \\
\hline Soluble fiber & 46.4 & 36.8 & 64.4 & 63.8 & 2.30 & 2.49 & $<0.001$ & 0.13 & 0.18 \\
\hline Digestible energy, MJ/kg DM & 11.5 & 11.0 & 11.3 & 11.4 & 0.16 & 0.22 & 0.69 & 0.26 & 0.19 \\
\hline Digestible CP, \% DM & 11.7 & 11.2 & 11.0 & 11.0 & 0.19 & 0.28 & 0.11 & 0.51 & 0.37 \\
\hline Ratio digestible [CP/energy], g/MJ & 10.1 & 10.2 & 9.70 & 9.71 & 0.09 & 0.12 & $<0.001$ & 0.61 & 0.69 \\
\hline
\end{tabular}

${ }^{1}$ LSF_Hn-6/n-3 = Low soluble fibre_High n-6/n-3 fatty acid ratio; LSF_Ln-6/n-3 = Low soluble fibre_Low n-6/n-3 fatty acid ratio; HSF_Hn-6/n-3 = High soluble fibre_High n-6/n-3 fatty acid ratio; HSF_Ln-6/n-3 = High soluble fibre_Low n-6/n-3 fatty acid ratio. ${ }^{\mathrm{a}-\mathrm{c}}$ Diet mean values in the same row with a different superscript differ, $\mathrm{P}<$ 0.05 
Table 4. Effect of level of soluble fiber and n-6/n-3 fatty acids profile and parity order on DE and digestible CP intake of rabbit does.

\begin{tabular}{|c|c|c|c|c|c|c|c|c|c|c|c|c|c|c|c|c|c|c|}
\hline \multirow[b]{3}{*}{$\mathrm{N}$} & \multicolumn{4}{|c|}{ Diets $^{1}$} & \multicolumn{4}{|c|}{ Parity order } & \multicolumn{4}{|c|}{ SEM } & \multicolumn{6}{|c|}{ P-value ${ }^{4}$} \\
\hline & $\begin{array}{l}\text { LSF_Hn- } \\
6 / \mathrm{n}-3 \\
\end{array}$ & $\begin{array}{l}\text { LSF_Ln- } \\
6 / \mathrm{n}-3 \\
\end{array}$ & $\begin{array}{c}\mathrm{HSF}_{-} \\
\mathrm{Hn}-6 / \mathrm{n}-3 \\
\end{array}$ & $\begin{array}{c}\mathrm{HSF}_{-} \mathrm{Ln}- \\
6 / \mathrm{n}-3 \\
\end{array}$ & 1 & 2 & 3 & 4 & $\begin{array}{c}\text { SF } \\
\text { and } \\
n-6 / n- \\
3\end{array}$ & $\begin{array}{c}\text { SFx } \\
\mathrm{n}-6 / \mathrm{n}- \\
3\end{array}$ & Parity & $\begin{array}{c}\text { SF } \times \text { Parity } \\
\text { and } \\
\text { n- } 6 / n- \\
3 \times \text { Parity }\end{array}$ & $\mathrm{SF}$ & $\begin{array}{l}n-6 / \\
n-3\end{array}$ & $\begin{array}{c}\text { SFx } \\
\mathrm{n}-6 / \mathrm{n}- \\
3\end{array}$ & Parity & $\begin{array}{c}\text { SF } \\
\times \text { Parity }\end{array}$ & $\begin{array}{l}n-6 / n- \\
3 x \\
\text { Parity }\end{array}$ \\
\hline & 15 & 18 & 22 & 20 & 75 & 75 & 62 & 40 & & & & & & & & & & \\
\hline \multicolumn{19}{|l|}{$\mathrm{ADFI}^{2}, \mathrm{~g} / \mathrm{d}$} \\
\hline $\mathrm{AI}^{3} 1$-Parturition 1 & 147 & 139 & 131 & 126 & - & - & - & - & 4.99 & 7.06 & - & - & 0.042 & 0.38 & 0.80 & - & - & - \\
\hline Parturition-AI & 292 & 310 & 289 & 279 & $232^{\mathrm{a}}$ & $300^{\mathrm{b}}$ & $314^{\mathrm{bc}}$ & $324^{\mathrm{c}}$ & 5.57 & 7.85 & 6.49 & 9.13 & 0.034 & 0.60 & 0.069 & $<0.001$ & 0.60 & 0.081 \\
\hline Lactation & 340 & 347 & 327 & 324 & $297^{\mathrm{a}}$ & $335^{\mathrm{b}}$ & $346^{\mathrm{bc}}$ & $361^{\mathrm{c}}$ & 6.19 & 8.73 & 6.57 & 9.27 & 0.047 & 0.81 & 0.55 & $<0.001$ & 0.37 & 0.90 \\
\hline Weaning-Parturition & 200 & 196 & 200 & 190 & $180^{\mathrm{a}}$ & $198^{\mathrm{b}}$ & $211^{\mathrm{b}}$ & - & 4.42 & 6.22 & 4.66 & 6.56 & 0.60 & 0.23 & 0.65 & $<0.001$ & 0.89 & 0.051 \\
\hline Among parturitions & 270 & 276 & 268 & 260 & $239^{\mathrm{a}}$ & $273^{\mathrm{b}}$ & $294^{c}$ & - & 4.52 & 6.37 & 4.76 & 6.71 & 0.16 & 0.83 & 0.28 & $<0.001$ & 0.67 & 0.76 \\
\hline \multicolumn{19}{|l|}{ DE intake, $\mathrm{MJ} / \mathrm{d}$} \\
\hline AI 1-Parturition 1 & 1.57 & 1.42 & 1.40 & 1.33 & - & - & - & - & 0.05 & 0.07 & - & - & 0.074 & 0.14 & 0.58 & - & - & - \\
\hline Parturition-AI & 3.12 & 3.17 & 3.09 & 2.93 & $2.44^{\mathrm{a}}$ & $3.14^{\mathrm{b}}$ & $3.30^{\mathrm{bc}}$ & $3.41^{\mathrm{c}}$ & 0.06 & 0.08 & 0.07 & 0.10 & 0.11 & 0.48 & 0.20 & $<0.001$ & 0.65 & 0.075 \\
\hline Lactation & 3.63 & 3.54 & 3.49 & 3.40 & $3.12^{\mathrm{a}}$ & $3.52^{\mathrm{b}}$ & $3.63^{\mathrm{bc}}$ & $3.80^{\mathrm{c}}$ & 0.06 & 0.09 & 0.07 & 0.10 & 0.13 & 0.32 & 0.98 & $<0.001$ & 0.38 & 0.88 \\
\hline Weaning-Parturition & 2.14 & 2.00 & 2.14 & 1.99 & $1.89^{\mathrm{a}}$ & $2.08^{\mathrm{b}}$ & $2.22^{\mathrm{b}}$ & - & 0.05 & 0.07 & 0.05 & 0.07 & 0.94 & 0.028 & 0.99 & $<0.001$ & 0.88 & 0.047 \\
\hline Among parturitions & 2.89 & 2.81 & 2.87 & 2.73 & $2.51^{\mathrm{a}}$ & $2.87^{\mathrm{b}}$ & $3.10^{\mathrm{c}}$ & - & 0.05 & 0.07 & 0.05 & 0.07 & 0.43 & 0.11 & 0.65 & $<0.001$ & 0.68 & 0.70 \\
\hline \multicolumn{19}{|l|}{$\begin{array}{l}\text { Digestible CP intake, } \\
\mathrm{g} / \mathrm{d}\end{array}$} \\
\hline AI 1-Parturition 1 & 16.0 & 14.6 & 13.5 & 12.9 & - & - & - & - & 0.53 & 0.75 & - & - & 0.005 & 0.18 & 0.57 & - & - & - \\
\hline Parturition-AI & 31.5 & 32.6 & 29.8 & 28.4 & $24.3^{\mathrm{a}}$ & $31.4^{\mathrm{b}}$ & $32.8^{\mathrm{bc}}$ & $33.8^{\mathrm{c}}$ & 0.59 & 0.83 & 0.68 & 0.96 & $<0.001$ & 0.86 & 0.15 & $<0.001$ & 0.50 & 0.072 \\
\hline Lactation & 36.8 & 36.4 & 33.6 & 33.1 & $31.1^{\mathrm{a}}$ & $35.0^{\mathrm{b}}$ & $36.1^{\mathrm{bc}}$ & $37.8^{\mathrm{c}}$ & 0.65 & 0.92 & 0.69 & 0.97 & $<0.001$ & 0.61 & 0.92 & $<0.001$ & 0.33 & 0.88 \\
\hline Weaning-Parturition & 21.7 & 20.5 & 20.6 & 19.3 & $18.8^{\mathrm{a}}$ & $20.7^{\mathrm{b}}$ & $22.1^{\mathrm{b}}$ & - & 0.46 & 0.64 & 0.48 & 0.68 & 0.079 & 0.067 & 0.93 & $<0.001$ & 0.90 & 0.054 \\
\hline Among parturitions & 29.3 & 29.0 & 27.6 & 26.5 & $25.0^{\mathrm{a}}$ & $28.5^{\mathrm{b}}$ & $30.8^{\mathrm{c}}$ & - & 0.47 & 0.66 & 0.50 & 0.70 & 0.003 & 0.29 & 0.54 & $<0.001$ & 0.63 & 0.77 \\
\hline
\end{tabular}

${ }^{1}$ LSF_Hn-6/n-3 = Low soluble fibre_High n-6/n-3 fatty acid ratio; LSF_Ln-6/n-3 = Low soluble fibre_Low n-6/n-3 fatty acid ratio; HSF_Hn-6/n-3 = High soluble fibre_High n-6/n-3 fatty acid ratio; HSF_Ln-6/n-3 = High soluble fibre_Low n-6/n-3 fatty acid ratio. ${ }^{2}$ ADFI = average daily feed intake. ${ }^{3}$ AI: Artificial insemination. ${ }^{4}$ No significant differences were found when the interaction $\mathrm{SF} \times \mathrm{n}-6 / \mathrm{n}-3 \times$ Parity was analyzed $(\mathrm{P} \geq 0.50) .{ }^{\mathrm{a}-\mathrm{c}}$ Parity order mean values in the same row with a different superscript differ, $\mathrm{P}<0.05$. 
Table 5. Effect of level of soluble fiber and n-6/n-3 fatty acids profile and parity order on performance of rabbit does and their litters.

\begin{tabular}{|c|c|c|c|c|c|c|c|c|c|c|c|c|c|c|c|c|c|c|}
\hline \multirow[b]{3}{*}{$\mathrm{N}$} & \multicolumn{4}{|c|}{ Diets $^{1}$} & \multicolumn{4}{|c|}{ Parity order } & \multicolumn{4}{|c|}{ SEM } & \multicolumn{6}{|c|}{ P-value $^{4}$} \\
\hline & $\begin{array}{c}\text { LSF_Hn- } \\
6 / n-3\end{array}$ & $\begin{array}{c}\text { LSF_Ln- } \\
6 / \mathrm{n}-3\end{array}$ & $\begin{array}{c}\mathrm{HSF}_{-} \\
\mathrm{Hn}-6 / \mathrm{n}-3 \\
\end{array}$ & $\begin{array}{c}\text { HSF_Ln- }_{-} \text {Ln-3 } \\
6 / \mathrm{n}-3\end{array}$ & 1 & 2 & 3 & 4 & $\begin{array}{c}\text { SF } \\
\text { and } \\
n-6 / n-3\end{array}$ & $\begin{array}{c}\text { SFx } \\
\text { n-6/n-3 }\end{array}$ & Parity & $\begin{array}{c}\text { SF } \times \text { Parity } \\
\text { and } \\
n-6 / n-3 \times \text { Parity }\end{array}$ & $\mathrm{SF}$ & $\begin{array}{l}n-6 / \\
n-3\end{array}$ & $\begin{array}{c}\text { SFx } \\
n-6 / n-3\end{array}$ & Parity & $\begin{array}{l}\text { SFx } \\
\text { Parity }\end{array}$ & $\begin{array}{l}\mathrm{n}-6 / \mathrm{n}-3 \\
\times \text { Parity }\end{array}$ \\
\hline & 15 & 18 & 22 & 20 & 75 & 75 & 62 & 40 & & & & & & & & & & \\
\hline Total born & 11.4 & 11.6 & 11.0 & 11.3 & $11.8^{\mathrm{bc}}$ & $12.5^{\mathrm{c}}$ & $10.7^{\mathrm{b}}$ & $10.2^{\mathrm{a}}$ & 0.43 & 0.61 & 0.50 & 0.71 & 0.59 & 0.66 & 0.87 & 0.003 & 0.90 & 0.95 \\
\hline Born alive & 10.3 & 11.0 & 10.0 & 10.5 & 10.7 & 11.4 & 10.0 & 9.74 & 0.44 & 0.63 & 0.51 & 0.72 & 0.55 & 0.36 & 0.90 & 0.073 & 0.46 & 0.97 \\
\hline Born dead & 0.98 & 0.64 & 0.95 & 0.78 & 1.17 & 1.04 & 0.69 & 0.45 & 0.19 & 0.27 & 0.24 & 0.33 & 0.84 & 0.34 & 0.75 & 0.14 & 0.57 & 0.88 \\
\hline $20 \mathrm{~d}$ lactation & 9.43 & 9.60 & 8.97 & 9.46 & $9.27^{\mathrm{a}}$ & $10.1^{\mathrm{b}}$ & $9.35^{\mathrm{a}}$ & $8.76^{\mathrm{a}}$ & 0.21 & 0.29 & 0.27 & 0.38 & 0.32 & 0.26 & 0.60 & 0.005 & 0.27 & 0.52 \\
\hline $25 \mathrm{~d}$ (weaning) & 9.37 & 9.55 & 8.91 & 9.38 & $9.22^{\mathrm{a}}$ & $10.0^{\mathrm{b}}$ & $9.27^{\mathrm{a}}$ & $8.70^{\mathrm{a}}$ & 0.21 & 0.29 & 0.27 & 0.38 & 0.29 & 0.27 & 0.61 & 0.008 & 0.31 & 0.61 \\
\hline Mortality at birth, $\%$ & 8.59 & 7.09 & 11.0 & 5.91 & 9.45 & 9.50 & 6.28 & 7.41 & 2.04 & 2.89 & 2.26 & 3.18 & 0.83 & 0.25 & 0.53 & 0.56 & 0.11 & 0.83 \\
\hline Mortality during lactation, $\%$ & 7.56 & 11.5 & 9.60 & 7.70 & 12.7 & 8.50 & 9.08 & 6.13 & 1.55 & 2.18 & 2.01 & 2.82 & 0.68 & 0.63 & 0.18 & 0.15 & 0.98 & 0.77 \\
\hline \multicolumn{19}{|l|}{ Weight of the litter, $\mathrm{kg}$} \\
\hline Birth & 0.551 & 0.572 & 0.554 & 0.562 & $0.479^{\mathrm{a}}$ & $0.620^{\mathrm{b}}$ & $0.570^{\mathrm{b}}$ & $0.570^{\mathrm{b}}$ & 0.19 & 0.26 & 0.23 & 0.32 & 0.90 & 0.60 & 0.82 & $<0.001$ & 0.96 & 0.87 \\
\hline $20 \mathrm{~d}$ & 2.907 & 2.983 & 2.827 & 2.846 & $2.588^{\mathrm{a}}$ & $2.946^{\mathrm{b}}$ & $2.990^{\mathrm{b}}$ & $3.039^{\mathrm{b}}$ & 0.56 & 0.79 & 0.65 & 0.92 & 0.18 & 0.55 & 0.72 & $<0.001$ & 0.045 & 0.64 \\
\hline \multicolumn{19}{|l|}{ Weight of the kits, $g$} \\
\hline Birth & 55.1 & 54.6 & 55.1 & 55.9 & $46.4^{\mathrm{a}}$ & $56.6^{\mathrm{b}}$ & $58.1^{\mathrm{b}}$ & $59.6^{\mathrm{b}}$ & 1.12 & 1.59 & 1.36 & 1.91 & 0.66 & 0.92 & 0.67 & $<0.001$ & 0.35 & 0.98 \\
\hline $20 \mathrm{~d}$ & 310 & 323 & 325 & 307 & $281^{\mathrm{a}}$ & $297^{\mathrm{b}}$ & $326^{c}$ & $360^{\mathrm{d}}$ & 5.68 & 8.00 & 7.04 & 9.92 & 0.91 & 0.78 & 0.053 & $<0.001$ & 0.90 & 0.11 \\
\hline $25 \mathrm{~d}$ (weaning) & $399^{\mathrm{ab}}$ & $414^{\mathrm{ab}}$ & $423^{\mathrm{a}}$ & $391^{\mathrm{b}}$ & $351^{\mathrm{a}}$ & $379^{\mathrm{b}}$ & $425^{c}$ & $473^{d}$ & 7.40 & 10.4 & 9.03 & 12.7 & 0.95 & 0.44 & 0.030 & $<0.001$ & 0.94 & 0.16 \\
\hline ADG of kits $0-25, g / d$ & 13.6 & 14.0 & 14.4 & 13.3 & $11.9^{\mathrm{a}}$ & $12.6^{\mathrm{b}}$ & $14.5^{\mathrm{c}}$ & $16.4^{\mathrm{d}}$ & 0.30 & 0.42 & 0.35 & 0.49 & 0.89 & 0.44 & 0.074 & $<0.001$ & 0.91 & 0.25 \\
\hline Kits ADFI $20-25$ d, g/d & 6.31 & 6.24 & 5.99 & 5.66 & $6.48^{\mathrm{bc}}$ & $6.78^{\mathrm{b}}$ & $5.67^{\mathrm{ab}}$ & $5.26^{\mathrm{a}}$ & 0.29 & 0.41 & 0.37 & 0.51 & 0.28 & 0.63 & 0.76 & 0.016 & 0.20 & 0.35 \\
\hline Litter ADFI $20-25 \mathrm{~d}, \mathrm{~g} / \mathrm{d}$ & 59.0 & 62.1 & 54.0 & 53.4 & $60.3^{\mathrm{b}}$ & $68.4^{\mathrm{c}}$ & $54.0^{\mathrm{ab}}$ & $45.9^{\mathrm{a}}$ & 3.16 & 4.46 & 3.83 & 5.39 & 0.13 & 0.77 & 0.68 & $<0.001$ & 0.047 & 0.46 \\
\hline Feed efficiency ${ }^{3}$ & 0.281 & 0.298 & 0.301 & 0.300 & $0.263^{\mathrm{a}}$ & $0.302^{\mathrm{b}}$ & $0.320^{\mathrm{b}}$ & - & 0.005 & 0.007 & 0.007 & 0.010 & 0.11 & 0.23 & 0.21 & $<0.001$ & 0.50 & 0.98 \\
\hline
\end{tabular}

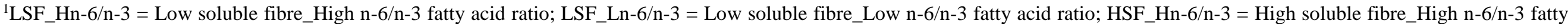

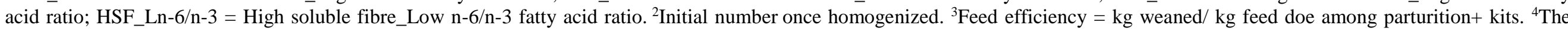

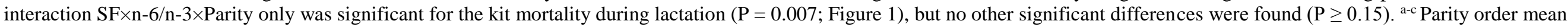
values in the same row with a different superscript differ. $\mathrm{P}<0.05$. 
Table 6. Effect of level of soluble fiber and n-6/n-3 fatty acids profile and parity order on doe weight, fertility and milk production of rabbit does.

\begin{tabular}{|c|c|c|c|c|c|c|c|c|c|c|c|c|c|c|c|c|}
\hline \multirow[b]{3}{*}{$\mathrm{N}$} & \multicolumn{4}{|c|}{ Diets $^{1}$} & \multicolumn{5}{|c|}{ Parity order } & \multicolumn{3}{|c|}{ SEM } & \multicolumn{4}{|c|}{$P$-value ${ }^{2}$} \\
\hline & \multirow{2}{*}{$\begin{array}{c}\begin{array}{c}\text { LSF_Hn- } \\
6 / n-3\end{array} \\
15\end{array}$} & \multirow{2}{*}{$\begin{array}{c}\begin{array}{c}\text { LSF_Ln- } \\
6 / n-3\end{array} \\
18\end{array}$} & \multirow{2}{*}{$\begin{array}{c}\begin{array}{c}\text { HSF_Hn- } \\
6 / n-3\end{array} \\
22\end{array}$} & \multirow{2}{*}{$\begin{array}{c}\begin{array}{c}\text { HSF_Ln- } \\
6 / n-3\end{array} \\
20\end{array}$} & \multirow{2}{*}{$\begin{array}{c}1 \\
75 \\
\end{array}$} & \multirow{2}{*}{2} & \multirow{2}{*}{$\begin{array}{l}3 \\
62 \\
\end{array}$} & \multirow{2}{*}{$\begin{array}{l}4 \\
40 \\
\end{array}$} & \multirow{2}{*}{$\frac{5}{40}$} & \multirow{2}{*}{$\begin{array}{c}\text { SF } \\
\text { and } \\
n-6 / n-3\end{array}$} & \multirow[t]{2}{*}{$\underset{\mathrm{n}-6 / \mathrm{n}-3}{\mathrm{SFx}}$} & \multirow[t]{2}{*}{ Parity } & \multirow[t]{2}{*}{ SF } & \multirow[t]{2}{*}{$n-6 / n-3$} & \multirow[t]{2}{*}{$\underset{n-6 / n-3}{S F x}$} & \multirow[t]{2}{*}{ Parity } \\
\hline & & & & & & & & & & & & & & & & \\
\hline \multicolumn{17}{|l|}{ Doe weight, $\mathrm{g}$} \\
\hline Parturition & 3939 & 3952 & 3999 & 3995 & $3910^{\mathrm{a}}$ & $3942^{\mathrm{ab}}$ & $3979^{\mathrm{bc}}$ & $4055^{\mathrm{c}}$ & - & 47.9 & 67.8 & 40.0 & 0.45 & 0.95 & 0.90 & 0.002 \\
\hline $\begin{array}{l}\text { Artificial insemination } \\
\text { (11 d) }\end{array}$ & 3931 & 4111 & 4094 & 4174 & 4034 & 4069 & 3996 & 4132 & 4158 & 55.3 & 78.2 & 53.7 & 0.15 & 0.10 & 0.53 & 0.066 \\
\hline Weaning (25d) & 4167 & 4237 & 4229 & 4236 & $4161^{\mathrm{a}}$ & $4163^{\mathrm{a}}$ & $4240^{\mathrm{b}}$ & $4305^{b}$ & - & 48.4 & 68.4 & 42.3 & 0.66 & 0.58 & 0.65 & 0.005 \\
\hline Number parturitions & 3.07 & 3.72 & 3.77 & 3.65 & - & - & - & - & - & 0.17 & 0.24 & - & 0.19 & 0.27 & 0.11 & - \\
\hline Fertility, $\%$ & 92.0 & 96.1 & 95.3 & 94.2 & $100^{\mathrm{b}}$ & $87.2^{\mathrm{a}}$ & $90.5^{\mathrm{a}}$ & $99.9^{\mathrm{b}}$ & - & 1.87 & 2.63 & 2.55 & 0.79 & 0.58 & 0.34 & $<0.001$ \\
\hline \multicolumn{17}{|l|}{ Milk production, $\mathrm{kg}$} \\
\hline $0-10 \mathrm{~d}$ & 1.73 & 1.75 & 1.70 & 1.64 & $1.42^{\mathrm{a}}$ & $1.75^{\mathrm{b}}$ & $1.80^{\mathrm{c}}$ & $1.85^{\mathrm{b}}$ & - & 0.029 & 0.042 & 0.034 & 0.11 & 0.61 & 0.30 & $<0.001$ \\
\hline $10-20 \mathrm{~d}$ & 2.63 & 2.69 & 2.57 & 2.52 & $2.35^{\mathrm{a}}$ & $2.51^{\mathrm{b}}$ & $2.69^{\mathrm{c}}$ & $2.86^{\mathrm{d}}$ & - & 0.045 & 0.064 & 0.053 & 0.089 & 0.93 & 0.38 & $<0.001$ \\
\hline $20-25 \mathrm{~d}$ & 1.35 & 1.35 & 1.36 & 1.28 & 1.34 & 1.28 & 1.33 & 1.39 & - & 0.032 & 0.045 & 0.038 & 0.55 & 0.34 & 0.39 & 0.29 \\
\hline $0-25 \mathrm{~d}$ & 5.73 & 5.80 & 5.67 & 5.46 & $5.09^{\mathrm{a}}$ & $5.60^{\mathrm{b}}$ & $5.84^{\mathrm{c}}$ & $6.13^{\mathrm{c}}$ & - & 0.088 & 0.124 & 0.099 & 0.12 & 0.60 & 0.26 & $<0.001$ \\
\hline
\end{tabular}

${ }^{1}$ LSF_Hn-6/n-3 = Low soluble fibre_High n-6/n-3 fatty acid ratio; LSF_Ln-6/n-3 = Low soluble fibre_Low n-6/n-3 fatty acid ratio; HSF_Hn-6/n-3 = High soluble fibre_High n-6/n-3 fatty acid ratio; HSF_Ln-6/n-3 = High soluble fibre_Low n-6/n-3 fatty acid ratio. ${ }^{2}$ Number of kits at $10 \mathrm{~d}$ for $0-10 \mathrm{~d}$ milk production, number of kits at $20 \mathrm{~d}$ for $10-20 \mathrm{~d}$ milk production, number of kits at $25 \mathrm{~d}$ for $20-25 \mathrm{~d}$ and $0-25 \mathrm{~d}$ milk production were significant as covariates $(\mathrm{P} \leq 0.001)$. No significant differences were found when the interactions $\mathrm{SF} \times$ Parity, $\mathrm{n}-6 / \mathrm{n}-3 \times \mathrm{Parity}$ and $\mathrm{SF} \times \mathrm{n}-6 / \mathrm{n}-3 \times$ Parity $(\mathrm{P} \geq 0.15)$ were analyzed. ${ }^{\mathrm{a}-\mathrm{c}}$ Parity order mean values in the same row with a different superscript differ, $\mathrm{P}<0.05$. 
Table 7. Effect of level of soluble fiber and n-6/n-3 fatty acids profile and parity order on body chemical composition and energy content of rabbit does.

\begin{tabular}{|c|c|c|c|c|c|c|c|c|c|c|c|c|c|c|c|c|c|c|}
\hline \multirow[b]{3}{*}{$\mathrm{N}$} & \multicolumn{4}{|c|}{ Diets $^{1}$} & \multicolumn{5}{|c|}{ Parity order } & \multicolumn{4}{|c|}{ SEM } & \multicolumn{5}{|c|}{$P$-value } \\
\hline & $\begin{array}{c}\text { LSF_Hn- } \\
6 / n-3 \\
\end{array}$ & $\begin{array}{c}\text { LSF_Ln- } \\
6 / \mathrm{n}-3 \\
\end{array}$ & $\begin{array}{c}\mathrm{HSF}_{-} \\
\text {Hn-6/n-3 } \\
\end{array}$ & $\begin{array}{c}\mathrm{HSF}_{-} \\
\text {Ln-6/n-3 } \\
\end{array}$ & 1 & 2 & 3 & 4 & 5 & $\begin{array}{c}\mathrm{SF} \\
\text { and } \\
\mathrm{n}-6 / \mathrm{n}- \\
3\end{array}$ & $\begin{array}{c}\mathrm{SFx} \\
\mathrm{n}-6 / \mathrm{n}- \\
3\end{array}$ & Parity & $\begin{array}{l}\text { SF×n- } \\
6 / \mathrm{n}-3 \\
\times \text { Parity }\end{array}$ & $\operatorname{Cov}^{1}$ & SF & $\begin{array}{l}n-6 / \\
n-3\end{array}$ & $\begin{array}{c}\mathrm{SFx} \\
\mathrm{n}-6 / \mathrm{n}- \\
3\end{array}$ & Parity \\
\hline & 15 & 18 & 22 & 20 & 75 & 75 & 62 & 40 & 40 & & & & & & & & & \\
\hline \multicolumn{19}{|l|}{ Parturition } \\
\hline Moisture, $\mathrm{g} / \mathrm{kg}$ & 609 & 611 & 609 & 607 & 612 & 611 & 609 & 605 & - & 0.23 & 0.33 & 0.25 & 0.49 & $<0.001$ & 0.48 & 0.93 & 0.53 & 0.20 \\
\hline Protein, $g / \mathrm{kg}$ & 179 & 179 & 179 & 178 & $177^{\mathrm{a}}$ & $179^{\mathrm{b}}$ & $180^{\mathrm{b}}$ & $179^{\mathrm{b}}$ & - & 0.03 & 0.05 & 0.04 & 0.07 & 0.001 & 0.51 & 0.76 & 0.75 & $<0.001$ \\
\hline Fat, $\mathrm{g} / \mathrm{kg}$ & 146 & 144 & 147 & 149 & 145 & 144 & 146 & 151 & - & 0.25 & 0.35 & 0.26 & 0.51 & $<0.001$ & 0.44 & 0.91 & 0.52 & 0.25 \\
\hline Ash, $\mathrm{g} / \mathrm{kg}$ & 31.7 & 31.8 & 31.6 & 31.6 & $31.1^{\mathrm{a}}$ & $31.7^{\mathrm{b}}$ & $31.9^{\mathrm{b}}$ & $31.9^{\mathrm{b}}$ & - & 0.01 & 0.02 & 0.01 & 0.03 & $<0.001$ & 0.38 & 0.86 & 0.88 & $<0.001$ \\
\hline $\mathrm{GE}, \mathrm{kJ} / 100 \mathrm{~g} \mathrm{BW}$ & 1100 & 1090 & 1101 & 1109 & 1089 & 1092 & 1100 & 1118 & - & 10.1 & 14.2 & 10.5 & 20.9 & $<0.001$ & 0.47 & 0.93 & 0.53 & 0.19 \\
\hline \multicolumn{19}{|c|}{$\begin{array}{l}\text { Artificial insemination (11 } \\
\text { d) }\end{array}$} \\
\hline Moisture, g/kg & 597 & 596 & 593 & 589 & $580^{\mathrm{a}}$ & $597^{\mathrm{b}}$ & $599^{\mathrm{b}}$ & $597^{\mathrm{b}}$ & 597 & 0.29 & 0.41 & 0.36 & 0.72 & $<0.001$ & 0.19 & 0.52 & 0.73 & $<0.00$ \\
\hline Protein, $g / \mathrm{kg}$ & 179 & 179 & 179 & 178 & $176^{\mathrm{a}}$ & $182^{\mathrm{b}}$ & $181^{\mathrm{b}}$ & $178^{\mathrm{a}}$ & $178^{\mathrm{a}}$ & 0.05 & 0.06 & 0.07 & 0.14 & $<0.001$ & 0.53 & 0.38 & 0.34 & $<0.001$ \\
\hline Fat, $\mathrm{g} / \mathrm{kg}$ & 156 & 157 & 160 & 165 & $173^{\mathrm{b}}$ & $155^{\mathrm{a}}$ & $153^{\mathrm{a}}$ & $158^{\mathrm{a}}$ & $158^{\mathrm{a}}$ & 0.28 & 0.40 & 0.34 & 0.67 & $<0.001$ & 0.16 & 0.47 & 0.65 & $<0.001$ \\
\hline Ash, g/kg & 31.4 & 31.1 & 31.1 & 30.7 & $30.0^{\mathrm{a}}$ & $30.8^{\mathrm{b}}$ & $31.6^{\mathrm{c}}$ & $31.3^{\mathrm{c}}$ & $31.6^{\mathrm{c}}$ & 0.01 & 0.02 & 0.02 & 0.04 & $<0.001$ & 0.11 & 0.14 & 0.84 & $<0.001$ \\
\hline GE, kJ/100 g BW & 1140 & 1147 & 1159 & 1176 & $1207^{\mathrm{b}}$ & $1139^{\mathrm{a}}$ & $1135^{\mathrm{a}}$ & $1150^{\mathrm{a}}$ & $1147^{\mathrm{a}}$ & 11.6 & 16.3 & 14.2 & 28.2 & $<0.001$ & 0.16 & 0.47 & 0.77 & $<0.001$ \\
\hline \multicolumn{19}{|l|}{ Weaning (25 d) } \\
\hline Moisture, g/kg & 630 & 636 & 635 & 634 & $652^{\mathrm{c}}$ & $639^{\mathrm{b}}$ & $635^{\mathrm{b}}$ & $610^{\mathrm{a}}$ & - & 0.50 & 0.71 & 0.50 & 0.99 & 0.11 & 0.78 & 0.72 & 0.61 & $<0.001$ \\
\hline Protein, $g / k g$ & 180 & 179 & 179 & 179 & $180^{\mathrm{b}}$ & $180^{\mathrm{b}}$ & $179^{\mathrm{b}}$ & $178^{\mathrm{a}}$ & - & 0.04 & 0.05 & 0.04 & 0.07 & $<0.001$ & 0.74 & 0.58 & 0.61 & 0.005 \\
\hline Fat, g/kg & 132 & 127 & 127 & 127 & $110^{\mathrm{a}}$ & $123^{\mathrm{b}}$ & $128^{c}$ & $152^{\mathrm{d}}$ & - & 0.46 & 0.65 & 0.45 & 0.90 & 0.076 & 0.75 & 0.72 & 0.67 & $<0.001$ \\
\hline Ash, g/kg & 31.3 & 31.4 & 31.3 & 31.4 & 31.3 & 31.4 & 31.5 & 31.2 & - & 0.01 & 0.02 & 0.01 & 0.03 & $<0.001$ & 0.97 & 0.67 & 0.79 & 0.36 \\
\hline $\mathrm{GE}, \mathrm{kJ} / 100 \mathrm{~g} \mathrm{BW}$ & 1026 & 1001 & 1004 & 1007 & $932^{\mathrm{a}}$ & $989^{b}$ & $1006^{\mathrm{b}}$ & $1111^{\mathrm{c}}$ & - & 20.5 & 28.9 & 20.3 & 40.3 & 0.095 & 0.78 & 0.70 & 0.62 & $<0.001$ \\
\hline
\end{tabular}

${ }^{1}$ LSF_Hn-6/n-3 = Low soluble fibre_High n-6/n-3 fatty acid ratio; LSF_Ln-6/n-3 = Low soluble fibre_Low n-6/n-3 fatty acid ratio; HSF_Hn-6/n-3 = High soluble fibre_High n-6/n-3 fatty acid ratio; HSF_Ln-6/n-3 = High soluble fibre_Low n-6/n-3 fatty acid ratio. ${ }^{2}$ Initial body weight. Initial proportion of moisture, protein, fat, ash and energy were not significant as covariates (P $\left.\geq 0.34\right)$. No significant differences were found for the interactions SF $\times$ Parity, $n-6 / n-3 \times P$ arity and SF $\times n-6 / n-3 \times$ Parity $(P \geq 0.12)$. ${ }^{\text {a-c }}$ parity order mean values in the same row with a different superscript differ, $\mathrm{P}<0.05$. 
Table 8. Effect of level of soluble fiber and n-6/n-3 fatty acids profile and parity order on the proportion of total removed, dead and culled does.

\begin{tabular}{|c|c|c|c|c|c|c|c|c|c|c|c|c|}
\hline \multirow[b]{3}{*}{$\mathrm{N}$} & \multicolumn{4}{|c|}{ Diets $^{1}$} & \multicolumn{4}{|c|}{ Parity order } & \multicolumn{4}{|c|}{ P-value } \\
\hline & $\begin{array}{c}\text { LSF_Hn- } \\
6 / \mathrm{n}-3\end{array}$ & $\begin{array}{c}\text { LSF_Ln-6/n- } \\
3\end{array}$ & $\begin{array}{c}\text { HSF_Hn- } \\
6 / \mathrm{n}-3\end{array}$ & $\begin{array}{c}\text { HSF_Ln- } \\
6 / n-3\end{array}$ & 1 & 2 & 3 & 4 & SF & $\begin{array}{l}\mathrm{n}-6 / \mathrm{n}- \\
3\end{array}$ & $\begin{array}{c}\text { SF } \times n-6 / n- \\
3\end{array}$ & Parity \\
\hline & 24 & 24 & 24 & 24 & 96 & 78 & 64 & 61 & & & & \\
\hline Total removed, \% & 62.5 & 37.5 & 16.7 & 29.1 & 18.7 & 17.9 & 4.69 & 0.00 & 0.005 & 0.75 & 0.056 & 0.11 \\
\hline Culled,\% & 20.8 & 20.8 & 4.17 & 12.5 & 7.29 & 8.97 & 0.00 & 0.00 & 0.059 & 0.37 & 0.37 & 0.96 \\
\hline Mortality, $\%$ & 41.7 & 16.7 & 12.5 & 29.2 & 11.5 & 8.97 & 4.69 & 0.00 & 0.13 & 0.38 & 0.13 & 0.54 \\
\hline
\end{tabular}

${ }^{1}$ LSF_Hn-6/n-3 = Low soluble fibre_High n-6/n-3 fatty acid ratio; LSF_Ln-6/n-3 = Low soluble fibre_Low n-6/n-3 fatty acid ratio; HSF_Hn-6/n-3 = High soluble fibre_High n-6/n-3 fatty acid ratio; HSF_Ln-6/n-3 = High soluble fibre_Low n-6/n-3 fatty acid ratio. ${ }^{\text {a-b }}$ parity order mean values in the same row with a different superscript differ, $\mathrm{P}<0.05$. 
Table 9. Effect of level of soluble fiber and n-6/n-3 fatty acids profile and parity order on milk composition at the $7^{\text {th }}$ day of lactation.

\begin{tabular}{|c|c|c|c|c|c|c|c|c|c|}
\hline \multirow[b]{3}{*}{$\mathrm{N}$} & \multicolumn{4}{|c|}{ Diets $^{1}$} & \multicolumn{2}{|c|}{ SEM } & \multicolumn{3}{|c|}{$P$-value } \\
\hline & $\begin{array}{l}\text { LSF_Hn- } \\
6 / n-3\end{array}$ & $\begin{array}{l}\text { LSF_Ln- } \\
6 / n-3\end{array}$ & $\begin{array}{c}\text { HSF_Hn- } \\
6 / n-3\end{array}$ & $\begin{array}{l}\text { HSF_Ln- } \\
6 / n-3\end{array}$ & $\begin{array}{l}\text { SF and } \\
n-6 / n-3\end{array}$ & SF $\times n-6 / n-3$ & SF & $n-6 / n-3$ & $\begin{array}{l}\text { SF } \times n- \\
6 / n-3\end{array}$ \\
\hline & 9 & 9 & 9 & 8 & & & & & \\
\hline$\overline{\mathrm{DM}}, \%$ & 30.0 & 31.4 & 30.6 & 31.5 & 0.53 & 0.75 & 0.65 & 0.13 & 0.79 \\
\hline $\mathrm{CP}, \%$ & 9.74 & 8.98 & 9.43 & 9.11 & 0.37 & 0.53 & 0.87 & 0.31 & 0.68 \\
\hline Fat, \% & 14.5 & 17.1 & 15.8 & 16.9 & 0.58 & 0.82 & 0.52 & 0.031 & 0.36 \\
\hline \multicolumn{10}{|l|}{$\begin{array}{l}\text { Fatty acids, } g / 100 \mathrm{~g} \text { of total fatty } \\
\text { acids }\end{array}$} \\
\hline Caproic, C6:0 & 0.258 & 0.241 & 0.255 & 0.258 & 0.009 & 0.040 & 0.60 & 0.56 & 0.44 \\
\hline Caprylic, C8:0 & 13.31 & 12.50 & 14.08 & 13.70 & 0.55 & 0.78 & 0.22 & 0.45 & 0.79 \\
\hline Capric, C10:0 & 14.62 & 13.81 & 15.89 & 15.02 & 0.46 & 0.65 & 0.066 & 0.20 & 0.96 \\
\hline Lauric, C12:0 & 2.593 & 2.461 & 2.909 & 2.668 & 0.11 & 0.16 & 0.12 & 0.26 & 0.74 \\
\hline Lauroleic, C12:1 & 0.011 & 0.039 & 0.054 & 0.015 & 0.018 & 0.025 & 0.72 & 0.83 & 0.20 \\
\hline Myristic, C14:0 & 1.893 & 1.966 & 1.870 & 1.830 & 0.06 & 0.08 & 0.36 & 0.85 & 0.52 \\
\hline Myristoleic, C14:1 & 0.181 & 0.166 & 0.163 & 0.179 & 0.014 & 0.020 & 0.88 & 0.98 & 0.45 \\
\hline Pentadecanoic, C15:0 & 0.359 & 0.373 & 0.427 & 0.422 & 0.006 & 0.009 & $<0.001$ & 0.69 & 0.32 \\
\hline Pentadecylic, C15:1 & $0.042^{\mathrm{a}}$ & $0.039^{\mathrm{a}}$ & $0.056^{\mathrm{b}}$ & $0.066^{\mathrm{b}}$ & 0.001 & 0.001 & $<0.001$ & 0.13 & 0.008 \\
\hline Palmitic, C16:0 & 14.90 & 16.02 & 14.23 & 14.49 & 0.46 & 1.29 & 0.10 & 0.30 & 0.51 \\
\hline Palmitoleic, C16:1n7 & 1.869 & 1.878 & 1.670 & 1.939 & 0.16 & 0.23 & 0.76 & 0.55 & 0.57 \\
\hline Hexadecenoic, C16:1n9 & 0.218 & 0.203 & 0.207 & 0.192 & 0.007 & 0.009 & 0.28 & 0.13 & 0.99 \\
\hline Margaric, C17:0 & 0.366 & 0.373 & 0.397 & 0.401 & 0.008 & 0.012 & 0.019 & 0.64 & 0.87 \\
\hline Heptadecenoic, C17:1 & 0.184 & 0.197 & 0.177 & 0.195 & 0.009 & 0.013 & 0.75 & 0.27 & 0.86 \\
\hline Stearic, C18:0 & 3.042 & 3.658 & 3.539 & 3.534 & 0.16 & 0.23 & 0.43 & 0.20 & 0.19 \\
\hline Oleic, C18:1n9 & 21.53 & 17.40 & 20.44 & 16.44 & 0.45 & 0.64 & 0.12 & $<0.001$ & 0.92 \\
\hline Vaccenic, C18:1n7 & 0.668 & 0.716 & 0.644 & 0.755 & 0.02 & 0.03 & 0.80 & 0.010 & 0.29 \\
\hline Linoleic, C18:2n6 & 21.58 & 22.34 & 20.64 & 21.60 & 0.25 & 0.36 & 0.025 & 0.022 & 0.78 \\
\hline$\alpha$-Linolenic, C18:3n3 & 1.202 & 4.361 & 1.113 & 5.020 & 0.16 & 0.23 & 0.22 & $<0.001$ & 0.11 \\
\hline$\gamma$-Linolenic, C18:3n6 & 0.210 & 0.228 & 0.245 & 0.213 & 0.030 & 0.040 & 0.78 & 0.85 & 0.51 \\
\hline Stearidonic, C18:4n3 & 0.009 & 0.071 & 0.011 & 0.090 & 0.004 & 0.005 & 0.055 & $<0.001$ & 0.097 \\
\hline Arachidic, C20:0 & 0.118 & 0.118 & 0.121 & 0.119 & 0.002 & 0.002 & 0.43 & 0.76 & 0.68 \\
\hline Gondoic, C20:1n9 & 0.195 & 0.178 & 0.183 & 0.167 & 0.004 & 0.006 & 0.059 & 0.010 & 0.94 \\
\hline Eicosadienoic, C20:2 & 0.160 & 0.153 & 0.156 & 0.157 & 0.004 & 0.006 & 0.97 & 0.60 & 0.48 \\
\hline Dihomo- $\gamma$-linolenic, C20:3n6 & 0.063 & 0.063 & 0.084 & 0.059 & 0.005 & 0.007 & 0.26 & 0.098 & 0.11 \\
\hline Arachidonic, C20:4n6 & 0.238 & 0.230 & 0.234 & 0.226 & 0.009 & 0.013 & 0.78 & 0.50 & 0.98 \\
\hline Eicosatrienoic, C20:3n3 & 0.017 & 0.032 & 0.015 & 0.039 & 0.002 & 0.003 & 0.43 & $<0.001$ & 0.18 \\
\hline Eicosatetraenoic, C20:4n3 & 0.015 & 0.021 & 0.022 & 0.024 & 0.001 & 0.002 & 0.009 & 0.027 & 0.18 \\
\hline Eicosapentaenoic, C20:5n3 & 0.021 & 0.037 & 0.017 & 0.041 & 0.003 & 0.004 & 0.97 & $<0.001$ & 0.31 \\
\hline Behenic, C22:0 & 0.083 & 0.081 & 0.100 & 0.099 & 0.010 & 0.015 & 0.23 & 0.93 & 0.95 \\
\hline Erucic, C22:1n9 & 0.037 & 0.043 & 0.036 & 0.042 & 0.002 & 0.003 & 0.83 & 0.087 & 0.92 \\
\hline SMCFA & 30.8 & 29.0 & 33.2 & 31.7 & 0.98 & 1.38 & 0.080 & 0.24 & 0.94 \\
\hline OFA & 0.95 & 0.98 & 1.06 & 1.08 & 0.021 & 0.030 & 0.002 & 0.37 & 0.96 \\
\hline SFA & 51.55 & 51.59 & 53.83 & 52.54 & 0.52 & 0.74 & 0.037 & 0.40 & 0.37 \\
\hline MUFA & 24.94 & 20.88 & 23.62 & 20.00 & 0.60 & 0.85 & 0.21 & $<0.001$ & 0.80 \\
\hline PUFA & 23.5 & 27.5 & 22.5 & 27.5 & 0.34 & 0.47 & 0.26 & $<0.001$ & 0.34 \\
\hline$n-6 / n-3$ & 17.5 & 5.91 & 18.0 & 4.26 & 0.50 & 0.69 & 0.43 & $<0.001$ & 0.13 \\
\hline$n-3$ & 1.262 & 4.530 & 1.178 & 5.212 & 0.17 & 0.23 & 0.21 & $<0.001$ & 0.11 \\
\hline$n-6$ & 22.10 & 22.86 & 21.19 & 22.09 & 0.23 & 0.33 & 0.017 & 0.019 & 0.84 \\
\hline $\mathrm{C} 18: 2 \mathrm{n} 6$ retained in milk, $\%$ & $68.2^{\mathrm{a}}$ & $90.6^{\mathrm{c}}$ & $80.7^{b}$ & $86.7^{\mathrm{bc}}$ & 1.85 & 2.62 & 0.10 & $<0.001$ & 0.002 \\
\hline $\mathrm{C} 18: 3 \mathrm{n} 3$ retained in milk, $\%$ & $64.0^{\mathrm{a}}$ & $68.5^{\mathrm{a}}$ & $76.1^{\mathrm{b}}$ & $70.9^{\mathrm{ab}}$ & 1.60 & 2.26 & 0.002 & 0.87 & 0.037 \\
\hline $\begin{array}{l}\mathrm{C} 18: 2 \mathrm{n} 6 \text { vs } \mathrm{C} 18: 3 \mathrm{n} 3 \text { retention, } \\
\%\end{array}$ & $4.13 \mathrm{a}$ & $22.1 \mathrm{c}$ & $4.63 \mathrm{a}$ & $15.8 \mathrm{~b}$ & 0.30 & 0.42 & $<0.001$ & $<0.001$ & $<0.001$ \\
\hline
\end{tabular}

${ }^{1}$ LSF_Hn-6/n-3 = Low soluble fibre_High n-6/n-3 fatty acid ratio; LSF_Ln-6/n-3 = Low soluble fibre_Low n-6/n-3 fatty acid ratio; HSF_Hn-6/n-3 = High soluble fibre_High n-6/n-3 fatty acid ratio; HSF_Ln-6/n-3 $=$ High soluble fibre_Low $\mathrm{n}-6 / \mathrm{n}-3$ fatty acid ratio. ${ }^{\mathrm{a}-\mathrm{c}}$ Diet mean values in the same row with a different superscript differ, $P<0.05$ 
Table 10. Effect of dietary soluble fiber and n-6/n-3 fatty acid ratio on body chemical composition and energy content of rabbits two days after weaning ( $26 \mathrm{~d}$ of age).

\begin{tabular}{|c|c|c|c|c|c|c|c|c|c|}
\hline \multirow[b]{3}{*}{$\mathrm{N}$} & \multicolumn{4}{|c|}{ Diets $^{1}$} & \multicolumn{2}{|c|}{ SEM } & \multicolumn{3}{|c|}{ P-value } \\
\hline & \multirow{2}{*}{$\frac{\text { LSF_Hn-6/n-3 }}{40}$} & \multirow{2}{*}{$\frac{\text { LSF_Ln-6/n-3 }}{40}$} & \multirow{2}{*}{$\frac{\text { HSF_Hn-6/n-3 }}{40}$} & \multirow{2}{*}{$\frac{\text { HSF_Ln-6/n-3 }}{40}$} & \multirow{2}{*}{$\begin{array}{l}\text { SF and } \\
n-6 / n-3\end{array}$} & \multirow{2}{*}{$\begin{array}{c}\text { SFx } \\
n-6 / n-3\end{array}$} & \multirow[t]{2}{*}{ SF } & \multirow[t]{2}{*}{$n-6 / n-3$} & \multirow[t]{2}{*}{$S F \times n-6 / n-3$} \\
\hline & & & & & & & & & \\
\hline Body weight & $447^{\mathrm{a}}$ & $496^{\mathrm{b}}$ & $471^{\mathrm{ab}}$ & $452^{\mathrm{a}}$ & 8.83 & 12.5 & 0.42 & 0.23 & 0.007 \\
\hline \multicolumn{10}{|l|}{ Body composition } \\
\hline Moisture, $\%$ & 69.5 & 70.3 & 69.6 & 70.0 & 0.24 & 0.34 & 0.70 & 0.068 & 0.51 \\
\hline Protein, \% DM & 56.8 & 56.9 & 56.4 & 57.0 & 0.13 & 0.18 & 0.46 & 0.044 & 0.12 \\
\hline Fat, \% DM & 25.9 & 25.8 & 25.9 & 25.6 & 0.11 & 0.16 & 0.59 & 0.16 & 0.33 \\
\hline Ash, \% DM & 11.1 & 11.1 & 11.2 & 11.1 & 0.03 & 0.04 & 0.038 & 0.39 & 0.75 \\
\hline GE, kJ/100 g BW & 2214 & 2211 & 2204 & 2209 & 2.13 & 3.00 & 0.036 & 0.71 & 0.14 \\
\hline \multicolumn{10}{|l|}{ Carcass composition } \\
\hline Moisture, \% & 71.0 & 71.5 & 71.5 & 71.3 & 0.15 & 0.21 & 0.57 & 0.41 & 0.10 \\
\hline Protein, \% DM & 61.9 & 61.3 & 62.2 & 61.6 & 0.19 & 0.27 & 0.30 & 0.021 & 0.95 \\
\hline Fat, \% DM & 22.6 & 22.1 & 22.0 & 22.3 & 0.20 & 0.29 & 0.49 & 0.59 & 0.18 \\
\hline Ash, DM & 15.4 & 15.9 & 16.0 & 15.8 & 0.20 & 0.28 & 0.39 & 0.61 & 0.15 \\
\hline $\mathrm{GE}, \mathrm{kJ} / 100 \mathrm{~g} \mathrm{BW}$ & 2157 & 2125 & 2117 & 2133 & 13.0 & 18.3 & 0.37 & 0.66 & 0.20 \\
\hline
\end{tabular}

${ }^{1}$ LSF_Hn-6/n-3 = Low soluble fibre_High n-6/n-3 fatty acid ratio; LSF_Ln-6/n-3 = Low soluble fibre_Low n-6/n-3 fatty acid ratio; HSF_Hn-6/n-3 = High soluble fibre_High n-6/n-3 fatty acid ratio; HSF_Ln-6/n-3

$=$ High soluble fibre_Low n-6/n-3 fatty acid ratio. 


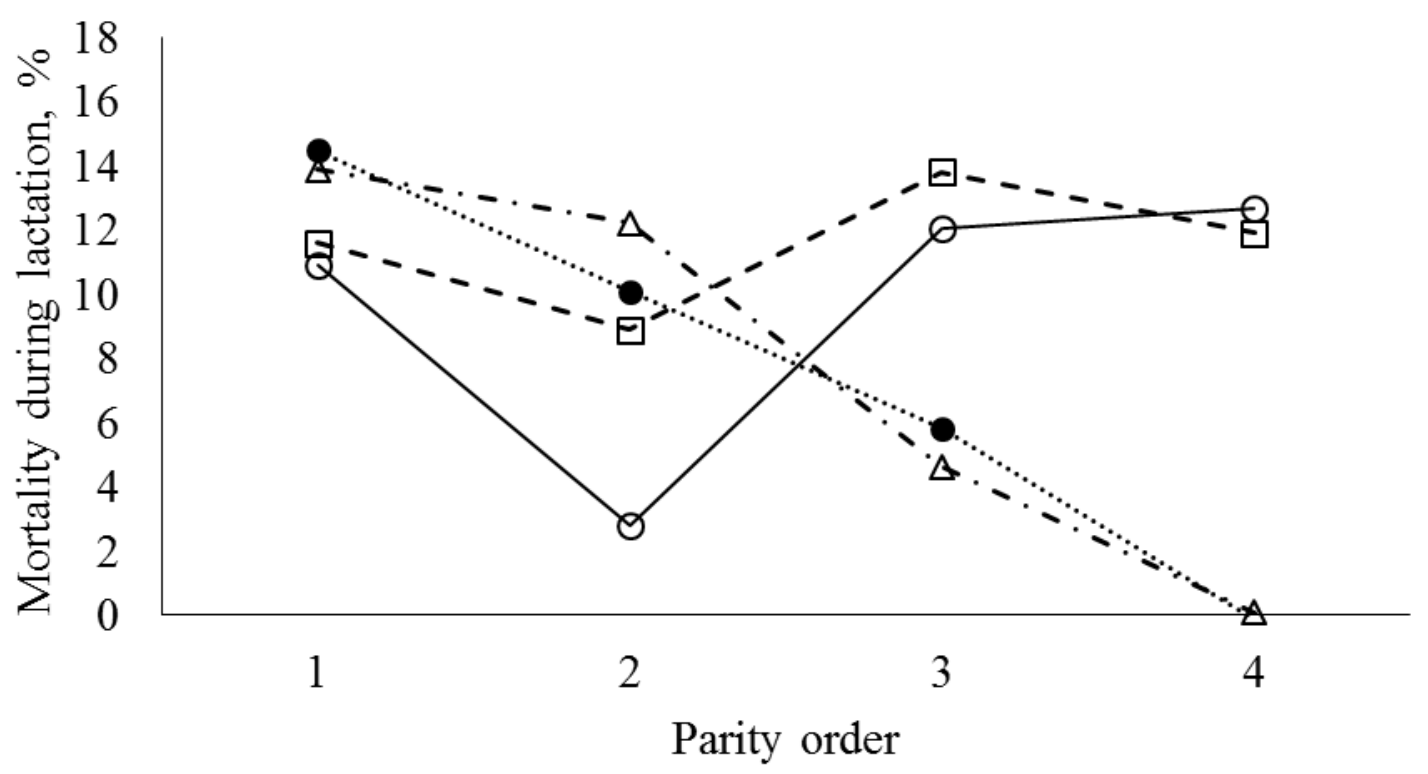

Figure 1. Effect of level of soluble fiber and n-6/n-3 fatty acids profile over parity order on litter mortality during lactation [LSF_Hn-6/n-3 • ; LSF_Ln-6/n-3 $\square$; HSF_ Hn-6/n-3 0 ; $\left.\mathrm{HSF}_{-} \mathrm{Ln}-6 / \mathrm{n}-3 \Delta\right] . \mathrm{P}=0.007$. 

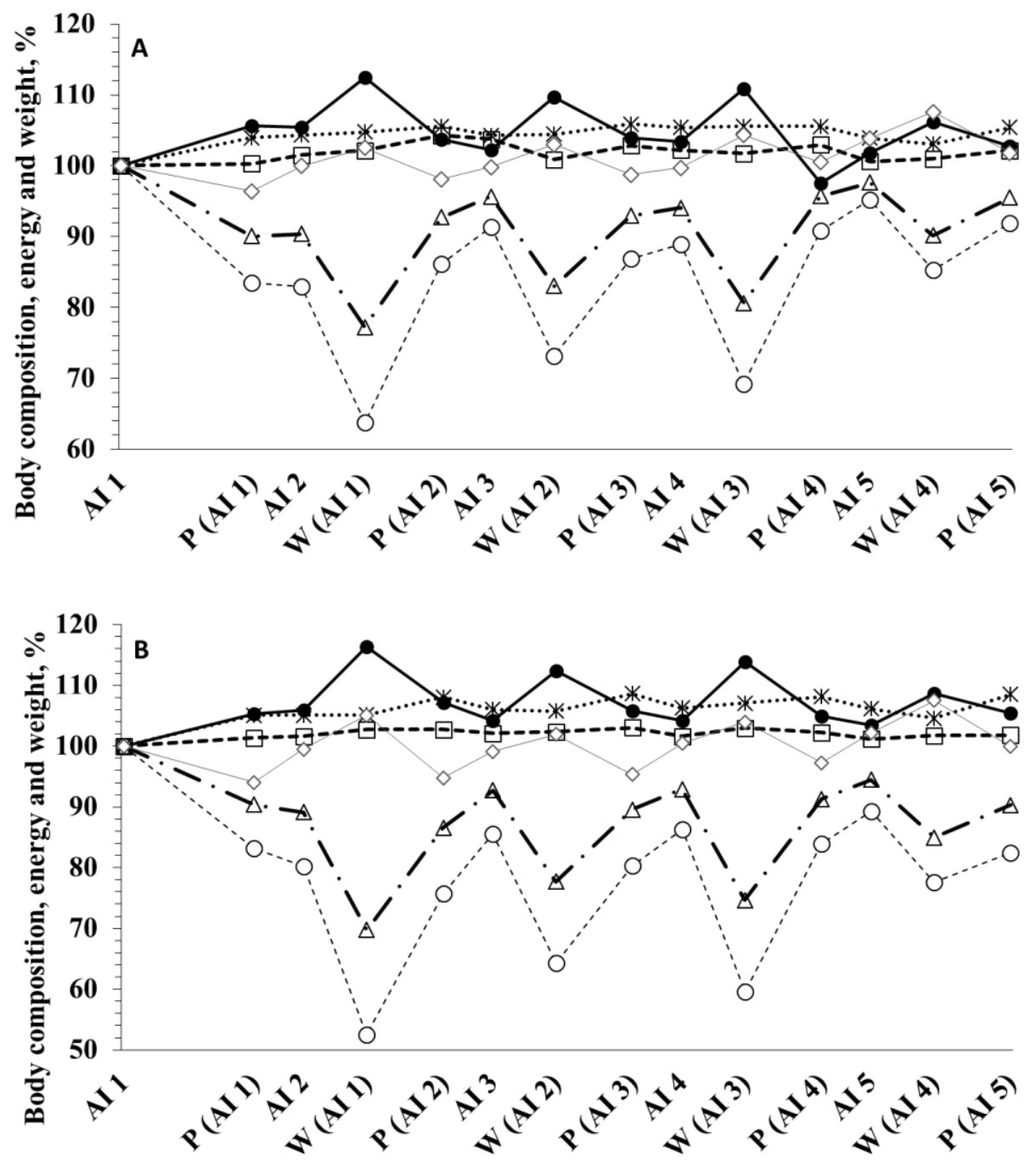

Productive/reproductive events along time

Figure 2. Evolution of body composition, energy and weight (Moisture $\bullet$, protein $\square$, fat $\circ$, ash *, energy $\Delta$, and body weight $\diamond$ ) over time (artificial insemination -AI-, parturition $-\mathrm{P}$ - and weaning $-\mathrm{W}-)$ of all rabbit does considered for productive traits $(\mathrm{n}=75$. Fig. $2 \mathrm{~A})$ or only those that had five consecutive parturitions $(\mathrm{n}=18$. Fig. $2 \mathrm{~B})$. Values obtained at first artificial insemination (AI 1) were considered as 100 (Fig. 2 A: Moisture: $59.6 \pm$ $1.66 \%$, protein: $17.7 \pm 0.40 \%$, fat: $15.7 \pm 1.62 \%$; ash: $3.07 \pm 0.09 \%$; energy: $11.40 \pm 0.71$ $\mathrm{MJ} / \mathrm{kg}$; Body weight: $3846 \pm 221 \mathrm{~g}$. Fig. 2 B: Moisture: $59.6 \pm 1.46 \%$, protein: $17.8 \pm$ $0.38 \%$, fat: $15.6 \pm 1.64 \%$; ash: $3.06 \pm 0.09 \%$; energy: $11.14 \pm 0.62 \mathrm{MJ} / \mathrm{kg}$; Body weight: $3904 \pm 139 \mathrm{~g})$ and the values obtained later were expressed as percentage of the value obtained at AI 1. P Time $<0.001$ in both figures.

AI 1, AI 2 , AI 3 and AI $4: 1^{\text {st }}, 2^{\text {nd, }} 3^{\text {rd }}$ and $4^{\text {th }}$ artificial insemination, respectively. P (IA 1), P (IA 2), P (IA 3), P (IA 4) and P (IA 5): Parturition corresponding to IA 1, AI 2, AI 3 and AI 4, respectively. W (IA 1), W (IA 2), W (IA 3) and W (IA 4): Weaning corresponding to IA 1, AI 2, AI 3 and AI 4, respectively. 


\subsection{Effect of dietary soluble fibre level and n-6/n-3 fatty acid ratio on growth performance and nutrient and energy efficiency in growing rabbits.}

\subsubsection{Introduction.}

The inclusion of $12 \%$ of soluble fibre in diets for growing rabbits affected with epizootic rabbit enteropathy (ERE) reduces the mortality, although it did not disappear (Trocino et al., 2013a), with different results in growth performance depending on the ingredients substituted (Gómez-Conde et al., 2009; Martínez-Vallespín et al., 2011). The recommended level of dietary soluble fibre is usually attained by including 15-25\% sugar beet pulp. However, its inclusion might impair the nutrient retention efficiency. Thus, the substitution of barley by sugar beet pulp limited the digestible energy intake and decreased the nitrogen and energy retention efficiencies when sugar beet pulp inclusion exceeded a 15\% (García et al., 1993; De Blas and Carabaño, 1996). In contrast, the substitution of alfalfa hay by sugar beet pulp did not affect these traits (Carabaño et al., 1997). It would be interesting the combination of soluble fibre with other nutrients that could have a synergy effect on rabbit health and that might improve nutrient efficiency. In this way, the dietary enrichment with omega-3 fatty acids using linseed, that decrease the $n-6 / n-3$ fatty acid ratio, also reduced the mortality in growing rabbits compared with a control diet (n-6/n-3 ratio: 1 vs. 4.8 Maertens et al., 2005; and 0.8 vs. 5.9 Casado et al., 2013). The reduction of the $n-6 / n-3$ ratio did not modify the fat content of different tissues in rabbits but their fatty acid profile (Bernardini et al., 1999; Dal Bosco et al., 2004). It is not known whether these changes in the fatty acid profile might improve the efficiency of retention of digestible energy and nitrogen.

Thus, the aim of this work was to study the effect of the combination of two levels of soluble fibre and two ratios of n-6/n-3 fatty acids on growth performance, in vivo chemical composition (body and carcass) and nitrogen and energy body and carcass retention and excretion in growing rabbits using a novel technique based on the bioelectrical impedance recording (Saiz et al.,2013 a, b and 2017). 


\subsubsection{Materials and methods.}

\subsubsection{Animals and housing.}

Crossbred hybrid rabbits (New Zealand White $\times$ Californian, $\mathrm{V} \times \mathrm{R}$ line from UPV, Valencia, Spain) obtained from a farm affected by ERE were used. Weaned rabbits came from multiparous rabbit does fed with the same diets described in Chapter 4.1. After weaning rabbits received the same diets offered to their mother during the lactation. Rabbits had ad libitum access to water throughout the experimental period. Rabbits were individually housed in flat-deck cages of $600 \times 250 \times 330 \mathrm{~mm}$ throughout the trial and kept under controlled environmental conditions $\left(18-23^{\circ} \mathrm{C}\right.$ and $12 \mathrm{~h}$ light: dark cycle lighting). All the experimental procedures used were approved by the Animal Ethics Committee of the Universidad Politécnica de Madrid, and were in compliance with the Spanish guidelines for care and use of animals in research (BOE, 2013).

\subsubsection{Growth performance and body chemical composition trial.}

Two hundred forty rabbits (60 per diet) weighing $458 \pm 89$ were weaned at $26 \mathrm{~d}$ of age and growth rate, feed intake, feed efficiency and mortality was recorded at 39 and at $62 \mathrm{~d}$ of age. In vivo body and carcass chemical composition and energy content was estimated using the bioelectrical impedance analysis (BIA) technique in 40 rabbits/diet from this group, weighing $460 \pm 80 \mathrm{~g}$ (Saiz et al., 2013a, b and 2017). Measurements of resistance and reactance were taken in rabbits with a body composition analyzer (Model Quantum II, RJL Systems, Detroit, MI, USA) at 27, 39 and $62 \mathrm{~d}$ of age. Multiple regression equations according to Saiz et al. (2013a, b and 2017) were used to estimate water, protein, ash, fat and energy proportions both in the body and in the carcass. Phase angle was calculated as the relation between the two vector components of impedance: resistance/reactance. It usually reflects electrical properties of tissues that are affected by disease, nutritional and hydration status (Kyle et al., 2004).

\subsubsection{Faecal digestibility trial.}

Another group of 56 rabbits (14/diet) weighing $449 \pm 54 \mathrm{~g}$ were weaned at $26 \mathrm{~d}$ of age and caged individually in metaboslism cages to determine the apparent faecal digestibility of gross energy and nitrogen. Feed intake and total faecal output were recorded for each rabbit during three consecutive days (from 39 to $42 \mathrm{~d}$ of age). Faeces 
daily collected were stored at $-20^{\circ} \mathrm{C}$, dried at $80^{\circ} \mathrm{C}$ for $48 \mathrm{~h}$ and ground with a $1 \mathrm{~mm}$ screen for analysis.

\subsubsection{Calculations of energy and nitrogen efficiency.}

Estimated values for the total body nitrogen and energy content were used to obtain the nitrogen and energy retention in vivo (NR in vivo and ER in vivo, respectively) between 26 and $62 \mathrm{~d}$ of age. Values were expressed per kg BW0.75 and day (where the BW was calculated as the average of the final and the initial body weight in each period). Estimated values for the carcass nitrogen and energy content were used to calculate the nitrogen and energy retention in the carcass (NR carcass and ER carcass, respectively) between 26 and $62 \mathrm{~d}$ of age. Values were expressed per kg BW0.75 and day. Moreover, nitrogen and GE intake (Ni and GEi, respectively) and digestible $\mathrm{N}$ and digestible energy intake (DNi and DEi, respectively) were recorded to calculate the overall $\mathrm{N}$ and GE in vivo body retention efficiency as: $\mathrm{NR}$ in vivo/Ni, NR in vivo/DNi, ER in vivo/GEi and ER in vivo/DEi, expressed as \%. Besides, the overall $\mathrm{N}$ and GE carcass retention efficiency as: NR carcass/DNi and ER carcass/DEi, both expressed as \%.

Total $\mathrm{N}$ and GE excretion as skin and viscera, faeces or heat production and urine were calculated as follows:

$\mathrm{N}$ excreted as skin and viscera $(\mathrm{g} / \mathrm{kg} \mathrm{BW} 0.75$ and day $)=(\mathrm{g} \mathrm{NR}$ in vivo $-\mathrm{g}$ NR carcass)/ kg BW0.75 and day.

$\mathrm{N}$ excreted as faeces $(\mathrm{g} / \mathrm{kg} \mathrm{BW} 0.75$ and day $)=(\mathrm{Ni}-\mathrm{DNi}) / \mathrm{kg} \mathrm{BW} 0.75$ and day.

$\mathrm{N}$ excreted as urine $(\mathrm{g} / \mathrm{kg} \mathrm{BW} 0.75$ and day $)=(\mathrm{DNi}-\mathrm{NR}$ in vivo $) / \mathrm{kg} \mathrm{BW} 0.75$ and day.

Energy excreted as skin and viscera $(\mathrm{MJ} / \mathrm{kg} \mathrm{BW0.75}$ and day $)=(\mathrm{MJ}$ ER in vivo MJ ER carcass)/ kg BW0.75 and day.

Energy excreted as faeces $(\mathrm{MJ} / \mathrm{kg} \mathrm{BW0.75}$ and day $)=(\mathrm{GEi}-\mathrm{DEi}) / \mathrm{kg} \mathrm{BW0.75}$ and day.

Energy excreted as urine and heat production $(\mathrm{MJ} / \mathrm{kg}$ BW0.75 and day $)=(\mathrm{DEi}-$ $\mathrm{RE}$ in vivo)/ $\mathrm{kg} \mathrm{BW} 0.75$ and day.

\subsubsection{Chemical analysis.}

Procedures of the AOAC (2000) were used to determine DM (method 934.01), ash (method 942.05), CP (method 968.06), ether extract (920.39), starch (amyloglucosidase- 
$\alpha$-amylase method; method 996.11), and total dietary fibre (985.29). Sugars were analyzed according to Yemm and Willis (1954). Dietary NDF, ADF and ADL were determined sequentially using the filter bag system (Ankom Technology, New York, NY). Dietary aNDFom was determined according to Mertens et al. (2002) using a thermostable amylase without any sodium sulphite added. Dietary ADFom and ADL were analyzed according Goering and Van Soest (1970). The soluble fiber was calculated as TDF-NDF (both corrected for ash and protein). Gross energy was measured by adiabatic bomb calorimeter (model 356, Parr Instrument Company, Moline, IL).

\subsubsection{Statistical analysis.}

A general linear model was used for data of growth performance, faecal digestibility, and nitrogen and energy balances (GLM procedure of SAS). The main factors studied were the level of soluble fibre, the n-6/n-3 fatty acid ratio, the age and their interactions. Weaning weight was used as a covariate for growth traits. Nitrogen and energy retained in the body and in the carcass were included as covariates for in vivo and carcass nitrogen and energy efficiency, respectively. Data of in vivo chemical composition along the time were analyzed as a factorial arrangement $2 \times 2$ repeated at 27 , 39 and $62 \mathrm{~d}$ of age using a mixed model for repeated measurements (Littell et al., 1996). It included the level of soluble fibre, the n- $6 / n-3$ fatty acid ratio, the age and their interactions and the rabbit was included as a random effect. Live weight and the in vivo composition (protein, fat, moisture, and ash) and energy content at $27 \mathrm{~d}$ of age were used as covariates for in vivo body and carcass chemical composition. Mortality was analyzed using a logistic regression (GENMOD procedure of SAS considering a binomial distribution) including the same variables in the model, and the results were transformed from the logit scale. All data are presented as least-squares means. When interactions were significant $(\mathrm{P}<0.05)$ comparisons among all the treatment means were made using a t-test.

\subsubsection{Results.}

At weaning, rabbits from litters whose mothers received LSF_Ln-6/n-3 diet, weighed more than those whose mothers were fed with LSF_Hn-6/n-3 diet $(\mathrm{P}=0.016$; Table 1), showing rabbits fed HSF_Hn-6/n-3 and HSF_Ln-6/n-3 diets intermediate values. The increase of soluble fiber reduced the mortality from 21.6 to $2.5 \%(\mathrm{P}<0.001)$ from weaning to $39 \mathrm{~d}$ of age (26-36 d of age), but in the second period (39 to $62 \mathrm{~d}$ of age) 
there were not differences among treatments (18.8\% on average). Consequently, in the whole experimental period the mortality was lower in rabbits fed with HSF diets compared to those of LSF groups ( 24.1 vs. $38.3 \%$; $P=0.018$ ), with no effect of the $n-6 / n-$ 3 ratio on mortality. The feed efficiency in the whole experimental period (26-62 d of age) improved with the increase of the level of soluble fibre (by 3.5\%; $\mathrm{P}=0.003$ ) and with the reduction of the $n-6 / n-3$ ratio (by $2.3 \% ; P \leq 0.048$ ). These effects were observed in the two phases of fattening (from 26 to $39 \mathrm{~d}$ of age, and from 39 to $62 \mathrm{~d}$ of age). The improvement of feed efficiency obtained with the increase of soluble fibre was due to the reduction of feed intake (by $3.5 \% ; \mathrm{P}=0.035$ ), as no effect on growth rate was observed. In contrast, the decrease of the $\mathrm{n}-6 / \mathrm{n}-3$ ratio improved the growth rate (by $4.8 \% ; \mathrm{P}=$ 0.007), with no effect on feed intake, which accounted for the increase of the feed efficiency. The treatments had no effect on the faecal digestibility of gross energy and DE content ( $\mathrm{P} \geq 0.24$; Table 2). The increase of soluble fibre decreased the digestible protein concentration and the ratio digestible protein/digestible energy (by $2.3 \% ; \mathrm{P} \leq$ 0.050). The reduction of the $n-6 / n-3$ ratio also decreased the digestible protein content (by $3 \% ; \mathrm{P}=0.009$ ).

At weaning, rabbits from litters whose mothers received Ln-6/n-3 diets tended to contain a lower body fat concentration and higher proportion of body moisture and protein ( $\mathrm{P} \leq 0.085$; Table 3). Dietary soluble fibre did not affect body composition at weaning. In contrast, the carcass protein proportion decreased in rabbits from Ln-6/n-3 groups (by $1.1 \% ; \mathrm{P}=0.043$ ), and rabbits from LSF_Ln-6/n-3 and HSF_Hn-6/n-3 groups tended to have a lower fat and energy content and a higher ash and moisture content $(\mathrm{P} \leq 0.089$; Table 4). There was no interaction soluble fibre $\times n-6 / n-3$ ratio $\times$ age for body or carcass composition, or soluble fibre $\times$ age $(\mathrm{P} \geq 0.16$. Data not shown). However, it was reported a relevant effect of the age on all traits of body and carcass composition $(\mathrm{P}<0.001$; Tables 3 and 4). There was an interaction of the dietary n-6/n-3 ratio with the age for live weight $(\mathrm{P}=0.048)$ and body protein $(\mathrm{P}=0.036)$, fat $(\mathrm{P}=0.015)$ and energy $(\mathrm{P}=0.022)$ contents (Table 3 and Figure 1). Rabbits fed Ln-6/n-3 diets tended to have less body fat and more body protein concentrations at $27 \mathrm{~d}$ of age, but this situation reversed at the end of fattening ( $62 \mathrm{~d}$ of age) when they tended to be heavier and to have more body fat and less body protein proportions $(\mathrm{P} \leq 0.11)$. The carcass protein content showed a similar evolution from 39 to the end of fattening than that found for body protein (Figure 2). Dietary soluble fibre had a minor influence on the body and carcass composition at 
different ages. Phase angle was not affected by treatments and was not related to mortality.

The total and digestible nitrogen and energy intake and the nitrogen and energy retained in the body and in the carcass used to calculate the nitrogen and energy efficiency are reported in Tables 6 and 7. The increase of soluble fibre and the reduction of the n6/n-3 ratio reduced the digestible nitrogen intake from 26 to $62 \mathrm{~d}$ of age (by $4 \%$.; $\mathrm{P} \leq$ 0.030). However, the amount of nitrogen retained in the body or in the carcass was not affected by treatments along the fattening period $(\mathrm{P} \geq 0.26)$. Consequently, the increase of dietary soluble fibre improved the in vivo body (NR in vivo/Ni and NR in vivo/DNi) and carcass (NR carcass/DNi) nitrogen retention efficiency from 26 to $62 \mathrm{~d}$ of age (by $3.5,5.4$ and $4.7 \%$ respectively; $\mathrm{P} \leq 0.034$ ), that is similar to that observed in the two phases of fattening. Moreover, the reduction of the $n-6 / n-3$ ratio increased the in vivo body ( $\mathrm{NR}$ in vivo/Ni and $\mathrm{NR}$ in vivo/DNi) and carcass (NR carcass/DNi) nitrogen retention efficiency from 26 to $62 \mathrm{~d}$ of age (by 2.4, 3.9 and 3.4\%, respectively; $\mathrm{P} \leq 0.043$ ), and a similar trend was also found in the two phases of fattening. These results were partially accounted for the trend to reduce these efficiencies in the LSF_Hn-6/n-3 groups. This improvement of the nitrogen efficiency was associated with a reduction of the urinary nitrogen excretion in HSF respect to LSF groups (by $12.6 \% ; \mathrm{P}=0.004$ ) and in Ln-6/n-3 respect to $\mathrm{Hn}-6 / \mathrm{n}-3$ group (by $12.1 \%$; $\mathrm{P}=0.006$ ) in the whole experimental period. In contrast, the increase of soluble fibre increased the faecal nitrogen excretion by $5.2 \%(\mathrm{P}=0.004)$, and this effect tended to be more pronounced for $\mathrm{Ln}-6 / \mathrm{n}-3$ group $(\mathrm{P}=$ 0.072). No effect of the type of fibre or $n-6 / n-3$ ratio was found on the nitrogen losses as skin + viscera.

The GE intake from 26 to $62 \mathrm{~d}$ of age decreased in HSF respect to LSF groups (by $3.7 \% ; \mathrm{P}=0.033$ ), but no effect was found for the DE intake. The ratio $n-6 / n-3$ had no effect on GE and DE intake. The body and carcass energy retention from 26 to $62 \mathrm{~d}$ of age was not affected by treatments $(\mathrm{P} \geq 0.13)$. The increase of soluble fibre improved the in vivo body (ER in vivo/GEi and ER in vivo/DEi) and carcass (ERcarcass/DEi) energy retention efficiency from 26 to $62 \mathrm{~d}$ of age (by 4.4, 2.7 and 3.0\%. P $\leq 0.042$; Table 7). The improvement of the retention of DE in the carcass in HSF groups was mainly due to the impairment observed in rabbis fed LSF_Hn-6/n-3 respect to those fed LSF_Ln-6/n-3 $\operatorname{diet}(\mathrm{P}=0.071)$. There was no influence of soluble fibre on the energy losses as urine and heat production, but they tended to be lower when the $n-6 / n-3$ ratio decreased $(P=0.058)$. 
The faecal losses of energy were lower with the HSF than with the LSF diets (by $6.1 \%$; $\mathrm{P}<0.001)$.

\subsubsection{Discussion.}

The dietary soluble fibre confirmed its role in reducing and delaying the mortality rate when rabbits are affected by ERE, although mortality was not below a reasonable threshold. This is in agreement with previous results using the same diets (Chapter 4.3) and with data reported by other authors (Gómez-Conde et al., 2007; Martínez-Vallespín et al., 2011; Xiccato et al., 2011). The reduction of the dietary n-6/n-3 ratio did not affect the mortality rate, alone or in combination with the soluble fibre, in spite to the relevant influence exerted on the immune system (Chapter 4.3) and to the positive results obtained by Maertens et al. (2005) and Casado et al. (2013). The lack of agreement with the latter studies might be related to the differences in the $n-6 / n-3$ ratios or in the dietary fatty acid profile (in this study the main change was the substitution of oleic for linolenic acid).

The increase of soluble fibre and the reduction of the $n-6 / n-3$ ratio improved the feed efficiency during the whole fattening period, but these effects were not additive. The increase of soluble fibre, or the level of inclusion of sugar beet pulp, is usually related to a decrease in feed intake, which sometimes is accompanied by an improvement of growth rate (Trocino et al., 2011) or not (Gómez-Conde et al., 2009). It might depend on the effect of the level of soluble fibre on DE intake, which in turn depends on the component substituted by soluble fibre (starch, insoluble fibre or both). When the level of inclusion of sugar beet pulp (substituting starch) was higher than $15 \%$ the feed intake reduction was more pronounced, compromising DE intake (and sometimes digestible protein intake), decreasing also feed conversion ratio and dressing out percentage (García et al., 1992ab, 1993; Martínez-Vallespín et al., 2011). However, it also depended on the insoluble fibre level, as the combination of high sugar beet pulp inclusion with low insoluble fibre level might limit these negative effects (Trocino et al., 2011). In contrast, when sugar beet pulp substitutes another source of fibre, feed intake also decreased but the DE intake remained constant, while digestible protein intake decreased (Carabaño et al., 1997). In this study, where the soluble fibre was substituted with both starch and fibre and it combined with a low insoluble fibre level did not modified DE intake but it reduced the digestible protein intake, in agreement with the lower digestible protein/DE ratio found in these diets. 
The nitrogen and energy retained were not modified by treatments. Since the diets were adequately balanced according to standard recommendations (De Blas and Mateos, 2010), rabbits met their nutrient requirements. Accordingly, the lower digestible protein intake, produced by the increase of the level of soluble fibre, combined with the lack of effect on the nitrogen retained led to an improvement of the efficiency of digestible nitrogen retained in the body and in the carcass. Thus, results are similar to those reported by García et al. (1993) for a similar level of inclusion of sugar beet pulp and confirmed that moderate levels of inclusion of soluble fibre/sugar beet pulp do not impair the nitrogenous retention efficiency. Furthermore, the nitrogen losses as urine decreased with the level of soluble fibre due to the lower digestible nitrogen intake and probably to the greater microbial activity in HSF rabbits, according to the higher of both TDF digestibility (ileal and faecal) and protein content in soft faeces compared to LSF rabbits (Chapter 4.3). However, the faecal nitrogen losses increased with the level of soluble fibre. It might be partially explained by the increase of faecal microbial nitrogen, since in the previous chapter it was hypothesized that not all the caecal contents were recycled through caecotrophy, but part of them might be excreted as hard faeces. In fact, the important fraction of the faecal N (45\% of total N, García et al., 2005) is lower than found by these authors for soft faeces (67\% of total $\mathrm{N}$ ). The microbial $\mathrm{N}$ concentration although it is probably also derived from caecal contents not recycled through caecotrophy.

The differences observed among treatments were lower for the energy than for the nitrogen retention efficiency. These results confirm that the moderate inclusion of soluble fibre/sugar beet pulp do not impair the energetic retention efficiency (García et al., 1993; Carabaño et al., 1997), but even improve this trait. This positive result might be related to the reduction of the energetic cost of urea synthesis according to the reduction of the nitrogen lost as urine (and to the small but not significant reduction of DE intake). However, this effect was not reflected in the energetic losses as urine + heat production, which might be due to the potential parallel increase of the heat of fermentation (included in the heat production fraction. De Blas and Carabaño, 1996), according to the increase of TDF digestibility with the level of soluble fibre and the lower energetic efficiency of volatile fatty acids compared with glucose (Chapter 4.3). The trend to reduce the energetic efficiency in LSF_Hn-6/n-3 group respect to the other treatments accounted for part of the effect found, but there is no clear explanation for this result. 
The positive effect of the reduction of the $n-6 / n-3$ ratio on feed efficiency during the fattening period was not reported by other authors (Bernardini et al., 1999; Dal Bosco et al., 2004; Maertens et al., 2005; Casado et al., 2013). It was explained by the increase of growth rate instead by a change in feed intake, and accordingly by a better nutrient utilization and/or a change in the composition of the weight gain. The reduction of the n6/n-3 ratio did not modify the retained nitrogen and energy, but changed the body and carcass composition. Rabbits fed Ln-6/n-3 diets had a higher body fat and energy content, and a lower body and carcass protein than those fed Hn-6/n-3 diets. It might account for the improvement of the efficiency of energy retention, because the fat deposition is more efficient than the protein one (Xiccato and Trocino, 2010). It may also reduce the heat production and explain the trend to reduce the loss of energy as urine + heat production in rabbits fed Ln-6/n-3 diets, together with the lower nitrogen losses in the urine observed. These effects are also influenced by the trend to reduce the energetic efficiency in LSF_Hn-6/n-3 group respect to the other, with no satisfactory explanation. The efficiency of digestible nitrogen retained in the body or in the carcass was also improved when the $n-6 / n-3$ ratio decreased due to the reduction of the digestible protein content in Ln- $6 / n-3$ diets that led to a reduction of digestible nitrogen intake, reducing nitrogen losses in urine.

The digestible nitrogen retention in the carcass in the second phase of the growing period (39-62 d) is one third lower than in the post-weaning period (25-39 d), whereas the digestible energy retention in the carcass is one fourth higher in the second phase, which remark the interest to use different diets along the fattening period to fit better with the requirements (Maertens et al., 1997). The growth performance recorded in this study is much higher than that obtained 25 years ago increasing growth rate (by $42 \%$ ), nitrogen and energy retention (by 54\%) and digestible nitrogen and energy intake (around 20\%), leading to an improvement of the retention efficiency of digestible energy (by 28\%) and nitrogen (by 56\%) in the same growth period (García et al., 1992a,b; García et al., 1993; Motta-Ferreira et al., 1996). It is accounted for the success of the genetic programs and the adjustment of the protein requirements that has led to a reduction of the dietary digestible protein/digestible energy ratio. However, the proportion of the nitrogen retained in the saleable portion (carcass) respect the whole nitrogen retained (59\%) is similar to that reported by Partridge et al. (1989).

In conclusion, the increase of soluble fibre improved the survival of fattening rabbits, but the reduction of the n- $6 / n-3$ ratio did not influence the health of rabbits during 
fattening. In contrast, both the increase of soluble fibre and the reduction of the $n-6 / n-3$ ratio improved the efficiency of the digestible energy and protein retained in the body and in the carcass. No additive effect of both factors was found. 
Table 1. Effect of dietary soluble fiber and n-6/n-3 fatty acid ratio on growth performance from weaning (26 d) to $62 \mathrm{~d}$ of age.

\begin{tabular}{|c|c|c|c|c|c|c|c|c|c|c|}
\hline \multirow[b]{3}{*}{$\mathrm{N}$} & \multicolumn{4}{|c|}{ Diets $^{1}$} & \multicolumn{2}{|c|}{ SEM } & \multicolumn{4}{|c|}{ P-value } \\
\hline & $\begin{array}{c}\text { LSF_Hn- } \\
6 / n-3\end{array}$ & $\begin{array}{c}\text { LSF_Ln- } \\
6 / n-3\end{array}$ & $\begin{array}{c}\text { HSF_Hn- } \\
6 / n-3\end{array}$ & $\begin{array}{c}\text { HSF_Ln- } \\
6 / n-3\end{array}$ & $\begin{array}{l}\text { SF and } \\
n-6 / n-3\end{array}$ & $\begin{array}{c}\mathrm{SF} \times \\
n-6 / n-3\end{array}$ & $\operatorname{Cov}^{2}$ & SF & $n-6 n-3$ & $\mathrm{SF} \times \mathrm{n}-6 / \mathrm{n}-3$ \\
\hline & 37 & 34 & 46 & 44 & & & & & & \\
\hline \multicolumn{11}{|l|}{26 to $39 \mathrm{~d}$ of age } \\
\hline Body weight $26 \mathrm{~d}$ & $426^{\mathrm{a}}$ & $480^{c}$ & $471^{\mathrm{bc}}$ & $440^{\mathrm{ab}}$ & 9.45 & 13.4 & - & 0.83 & 0.39 & 0.001 \\
\hline Weight gain, g/d & 42.3 & 46.1 & 45.4 & 46.0 & 1.05 & 1.49 & 0.003 & 0.31 & 0.14 & 0.30 \\
\hline Feed efficiency, g/g & 0.563 & 0.610 & 0.617 & 0.646 & 0.010 & 0.014 & 0.039 & 0.002 & 0.009 & 0.55 \\
\hline Mortality $^{3}, \%$ & 20.0 & 23.3 & 3.33 & 1.67 & - & - & - & $<0.001$ & 0.69 & 0.48 \\
\hline \multicolumn{11}{|l|}{39 to $62 \mathrm{~d}$ of age } \\
\hline Body weight $39 \mathrm{~d}$ & 995 & 1040 & 1033 & 1038 & 15.0 & 21.4 & $<0.001$ & 0.51 & 0.17 & 0.27 \\
\hline Weight gain, g/d & 49.6 & 52.4 & 49.2 & 51.1 & 0.68 & 0.96 & 0.20 & 0.37 & 0.015 & 0.65 \\
\hline Feed intake, g/d & 137 & 143 & 133 & 136 & 1.80 & 2.57 & $<0.001$ & 0.034 & 0.093 & 0.56 \\
\hline Feed efficiency, g/g & 0.364 & 0.368 & 0.370 & 0.375 & 0.004 & 0.006 & 0.014 & 0.26 & 0.50 & 0.90 \\
\hline \multicolumn{11}{|l|}{26 to $62 \mathrm{~d}$ of age } \\
\hline Body weight $62 \mathrm{~d}$ & 2135 & 2253 & 2166 & 2213 & 21.4 & 30.4 & $<0.001$ & 0.87 & 0.007 & 0.25 \\
\hline Weight gain, g/d & 46.1 & 49.3 & 46.9 & 48.2 & 0.59 & 0.84 & 0.062 & 0.88 & 0.007 & 0.25 \\
\hline Feed intake, g/d & 112 & 117 & 110 & 111 & 1.46 & 2.08 & $<0.001$ & 0.035 & 0.17 & 0.36 \\
\hline Feed efficiency, g/g & 0.411 & 0.423 & 0.428 & 0.435 & 0.003 & 0.005 & $<0.001$ & 0.003 & 0.048 & 0.71 \\
\hline Mortality $^{3}, \%$ & 35.0 & 41.7 & 23.3 & 25.0 & - & - & - & 0.018 & 0.51 & 0.74 \\
\hline
\end{tabular}

${ }^{1}$ LSF_Hn-6/n-3 = Low soluble fibre_High n-6/n-3 fatty acid ratio; LSF_Ln-6/n-3 = Low soluble fibre_Low n-6/n-3 fatty acid ratio; HSF_Hn-6/n-3 = High soluble fibre_High $\mathrm{n}-6 / \mathrm{n}-3$ fatty acid ratio; HSF_Ln-6/n-3 = High soluble fibre_Low n-6/n-3 fatty acid ratio. ${ }^{2}$ weight at weaning $(26 \mathrm{~d})$ as a covariate. ${ }^{3} \mathrm{n}=60$ (initial number of rabbits/treatment).

${ }^{\mathrm{a}-\mathrm{c}}$ Fattening mean values in the same column with a different superscript differ $\mathrm{P}<0.05$. 
Table 2. Effect of dietary soluble fiber and n-6/n-3 fatty acid ratio on faecal digestibility.

\begin{tabular}{|c|c|c|c|c|c|c|c|c|c|}
\hline \multirow[b]{3}{*}{$\mathrm{N}$} & \multicolumn{4}{|c|}{ Diets $^{1}$} & \multicolumn{2}{|c|}{ SEM } & \multicolumn{3}{|c|}{ P-value } \\
\hline & $\begin{array}{c}\text { LSF_Hn-6/n- } \\
3 \\
\end{array}$ & $\begin{array}{c}\text { LSF_Ln-6/n- } \\
3 \\
\end{array}$ & $\begin{array}{c}\text { HSF_Hn- } \\
6 / n-3 \\
\end{array}$ & $\begin{array}{c}\text { HSF_Ln-6/n- } \\
3 \\
\end{array}$ & $\begin{array}{c}\text { SF and } \\
\text { n- } 6 / n- \\
3\end{array}$ & $\begin{array}{c}\mathrm{SF} \times \\
\mathrm{n}-6 / \mathrm{n}- \\
3\end{array}$ & SF & $\begin{array}{c}n-6 / n- \\
3\end{array}$ & $\begin{array}{c}\mathrm{SF} \times \mathrm{n}-6 / \mathrm{n}- \\
3\end{array}$ \\
\hline & 15 & 13 & 15 & 13 & & & & & \\
\hline Gross energy, \% DM & 65.1 & 64.4 & 65.5 & 65.8 & 0.55 & 0.77 & 0.24 & 0.79 & 0.50 \\
\hline Crude protein, \% DM & 77.6 & 77.2 & 76.2 & 75.2 & 0.56 & 0.79 & 0.040 & 0.39 & 0.75 \\
\hline Digestible energy, MJ/kg DM & 12.0 & 11.7 & 12.0 & 11.9 & 0.10 & 0.14 & 0.70 & 0.26 & 0.52 \\
\hline Digestible crude protein, $\% \mathrm{DM}$ & 13.1 & 12.6 & 12.8 & 12.5 & 0.94 & 0.13 & 0.14 & 0.009 & 0.40 \\
\hline Digestible protein/digestible energy, g/MJ & 1.09 & 1.08 & 1.07 & 1.05 & 0.007 & 0.001 & 0.050 & 0.20 & 0.99 \\
\hline
\end{tabular}

${ }^{1}$ LSF_Hn-6/n-3 = Low soluble fibre_High n-6/n-3 fatty acid ratio; LSF_Ln-6/n-3 = Low soluble fibre_Low n-6/n-3 fatty acid ratio; HSF_Hn-6/n-3 = High soluble fibre_High n-6/n-3 fatty acid ratio; HSF_Ln-6/n-3 = High soluble fibre_Low n-6/n-3 fatty acid ratio. ${ }^{\mathrm{a}-\mathrm{c}}$ Fattening mean values in the same column with a different superscript differ P < 0.05 
Table 3. Effect of dietary soluble fiber and n-6/n-3 fatty acid ratio on body chemical composition and energy content of weaning rabbits at 25,39 and $62 \mathrm{~d}$ of age.

\begin{tabular}{|c|c|c|c|c|c|c|c|c|c|c|c|}
\hline \multirow[b]{3}{*}{$\mathrm{N}$} & \multicolumn{4}{|c|}{ Diets $^{1}$} & \multicolumn{2}{|c|}{ SEM } & \multicolumn{5}{|c|}{ P-value } \\
\hline & \multirow{2}{*}{$\frac{\text { LSF_Hn-6/n-3 }}{25}$} & \multirow{2}{*}{$\frac{\text { LSF_Ln-6/n-3 }}{25}$} & \multirow{2}{*}{$\frac{\text { HSF_Hn-6/n-3 }}{31}$} & \multirow{2}{*}{$\frac{\text { HSF_Ln-6/n-3 }}{28}$} & \multirow{2}{*}{$\begin{array}{l}\text { SF and } \\
n-6 / n-3\end{array}$} & \multirow{2}{*}{$\begin{array}{c}\mathrm{SF} \times \\
n-6 / n-3\end{array}$} & \multirow[t]{2}{*}{$\operatorname{Cov}^{2}$} & \multirow[t]{2}{*}{$\operatorname{Cov}^{3}$} & \multirow[t]{2}{*}{$\mathrm{SF}$} & \multirow[t]{2}{*}{$n-6 / n-3$} & \multirow[t]{2}{*}{$\mathrm{SF} \times \mathrm{n}-6 / \mathrm{n}-3$} \\
\hline & & & & & & & & & & & \\
\hline \multicolumn{12}{|l|}{$27 \mathrm{~d}$ of age } \\
\hline Body weight & $432^{\mathrm{a}}$ & $486^{\mathrm{b}}$ & $466^{\mathrm{ab}}$ & $444^{\mathrm{ab}}$ & 11.3 & 16.0 & - & - & 0.78 & 0.30 & 0.016 \\
\hline Moisture, \% & 69.3 & 70.6 & 69.7 & 69.8 & 0.28 & 0.39 & - & - & 0.68 & 0.085 & 0.11 \\
\hline Protein, $\%$ & 56.7 & 56.9 & 56.4 & 56.9 & 0.15 & 0.21 & - & - & 0.51 & 0.076 & 0.56 \\
\hline Fat, \% & 26.0 & 25.7 & 26.0 & 25.6 & 0.13 & 0.19 & - & - & 0.76 & 0.064 & 0.78 \\
\hline Ash, \% & 11.1 & 11.1 & 11.2 & 11.2 & 0.03 & 0.05 & - & - & 0.13 & 0.85 & 0.98 \\
\hline Energy ${ }^{4}$ & 2215 & 2208 & 2205 & 2207 & 2.53 & 3.58 & - & - & 0.12 & 0.44 & 0.21 \\
\hline Phase angle & 8.29 & 8.21 & 7.55 & 8.24 & & & - & - & 0.16 & 0.22 & 0.13 \\
\hline \multicolumn{12}{|l|}{$39 \mathrm{~d}$ of age } \\
\hline Body weight & 1025 & 1026 & 1019 & 1032 & 17.9 & 25.5 & $<0.001$ & - & 0.99 & 0.78 & 0.82 \\
\hline Moisture, \% & $70.3^{\mathrm{a}}$ & $71.0^{\mathrm{b}}$ & $71.3^{b}$ & $70.7^{\mathrm{ab}}$ & 0.18 & 0.26 & $<0.001$ & 0.63 & 0.22 & 0.73 & 0.009 \\
\hline Protein, $\%$ & 57.2 & 57.6 & 57.7 & 57.3 & 0.17 & 0.24 & $<0.001$ & 0.84 & 0.65 & 0.82 & 0.12 \\
\hline Fat, \% & 25.6 & 25.3 & 25.2 & 25.5 & 0.18 & 0.26 & $<0.001$ & 0.77 & 0.65 & 0.87 & 0.22 \\
\hline Ash, $\%$ & 12.0 & 12.0 & 12.1 & 12.1 & 0.05 & 0.07 & $<0.001$ & 0.36 & 0.37 & 0.79 & 0.83 \\
\hline Energy ${ }^{4}$ & 2189 & 2183 & 2183 & 2183 & 2.47 & 3.52 & $<0.001$ & 0.84 & 0.43 & 0.41 & 0.37 \\
\hline Phase angle & 10.7 & 10.5 & 10.3 & 10.5 & & & - & - & 0.49 & 0.89 & 0.51 \\
\hline \multicolumn{12}{|l|}{$62 \mathrm{~d}$ of age } \\
\hline Body weight & 2158 & 2231 & 2160 & 2208 & 25.8 & 36.7 & $<0.001$ & - & 0.77 & 0.11 & 0.75 \\
\hline Moisture, \% & 66.5 & 66.6 & 66.9 & 66.7 & 0.19 & 0.27 & $<0.001$ & 0.80 & 0.33 & 0.83 & 0.50 \\
\hline Protein, $\%$ & 47.9 & 47.4 & 48.1 & 47.6 & 0.21 & 0.23 & $<0.001$ & 0.093 & 0.64 & 0.11 & 0.92 \\
\hline Fat, \% & 32.6 & 33.4 & 32.6 & 33.3 & 0.31 & 0.44 & $<0.001$ & 0.22 & 0.83 & 0.10 & 0.87 \\
\hline Ash, $\%$ & 10.4 & 10.3 & 10.4 & 10.3 & 0.07 & 0.10 & $<0.001$ & 0.24 & 0.64 & 0.24 & 0.87 \\
\hline Energy $^{4}$ & 2357 & 2368 & 2352 & 2364 & 6.96 & 9.90 & $<0.001$ & 0.24 & 0.64 & 0.24 & 0.98 \\
\hline Phase angle & 10.9 & 10.7 & 10.6 & 10.7 & & & - & - & 0.48 & 0.95 & 0.61 \\
\hline
\end{tabular}

${ }^{1}$ LSF_Hn-6/n-3 = Low soluble fibre_High n-6/n-3 fatty acid ratio; LSF_Ln-6/n-3 = Low soluble fibre_Low n-6/n-3 fatty acid ratio; HSF_Hn-6/n-3 = High soluble fibre_High n-6/n-3 fatty acid ratio; HSF_Ln-6/n-3 = High soluble fibre_Low n-6/n-3 fatty acid ratio. ${ }^{2}$ weight at weaning (27 d) as a covariate. ${ }^{3}$ initial body corporal condition $\left(27 \mathrm{~d}\right.$ ) as a covariate. ${ }^{4}$ gross energy, $\mathrm{kJ} / 100 \mathrm{~g}$. ${ }^{\mathrm{a}-\mathrm{c}}$ Fattening mean values in the same column with a different superscript differ $\mathrm{P}<0.05$. 
Table 4. Effect of dietary soluble fiber and n-6/n-3 fatty acid ratio on carcass composition and energy content of weaning rabbits at 27,39 and 62 d of age.

\begin{tabular}{|c|c|c|c|c|c|c|c|c|c|c|c|}
\hline \multirow[b]{3}{*}{$\mathrm{N}$} & \multicolumn{4}{|c|}{ Diets $^{1}$} & \multicolumn{2}{|c|}{ SEM } & \multicolumn{5}{|c|}{ P-value } \\
\hline & \multirow{2}{*}{$\frac{\text { LSF_Hn-6/n-3 }}{25}$} & \multirow{2}{*}{$\frac{\text { LSF_Ln-6/n-3 }}{25}$} & \multirow{2}{*}{$\frac{\text { HSF_Hn-6/n-3 }}{31}$} & \multirow{2}{*}{$\frac{\text { HSF_Ln-6/n-3 }}{28}$} & \multirow{2}{*}{$\begin{array}{l}\text { SF and } \\
n-6 / n-3\end{array}$} & \multirow{2}{*}{$\begin{array}{c}\mathrm{SF} \times \\
n-6 / n-3\end{array}$} & \multirow[t]{2}{*}{$\operatorname{Cov}^{2}$} & \multirow[t]{2}{*}{$\operatorname{Cov}^{3}$} & \multirow[t]{2}{*}{$\mathrm{SF}$} & \multirow[t]{2}{*}{$n-6 / n-3$} & \multirow[t]{2}{*}{$\mathrm{SF} \times \mathrm{n}-6 / \mathrm{n}-3$} \\
\hline & & & & & & & & & & & \\
\hline \multicolumn{12}{|l|}{$27 \mathrm{~d}$ of age } \\
\hline Moisture, \% & 71.1 & 71.7 & 71.7 & 71.3 & 0.17 & 0.32 & - & - & 0.69 & 0.77 & 0.043 \\
\hline Protein, $\%$ & 62.1 & 61.1 & 62.2 & 61.8 & 0.24 & 0.35 & - & - & 0.30 & 0.043 & 0.37 \\
\hline Fat, $\%$ & 22.6 & 21.8 & 21.8 & 22.2 & 0.23 & 0.33 & - & - & 0.54 & 0.55 & 0.057 \\
\hline Ash, \% & 15.5 & 16.2 & 16.4 & 15.7 & 0.23 & 0.33 & - & - & 0.53 & 0.98 & 0.067 \\
\hline Energy ${ }^{4}$ & 2148 & 2111 & 2097 & 2133 & 15.2 & 21.5 & - & - & 0.51 & 0.98 & 0.089 \\
\hline \multicolumn{12}{|l|}{$39 \mathrm{~d}$ of age } \\
\hline Moisture, \% & $69.8^{\mathrm{a}}$ & $70.3^{\mathrm{ab}}$ & $70.5^{b}$ & $70.0^{\mathrm{ab}}$ & 0.16 & 0.23 & $<0.001$ & 0.056 & 0.32 & 0.94 & 0.043 \\
\hline Protein, \% & 60.1 & 60.0 & 60.0 & 60.0 & 0.04 & 0.06 & $<0.001$ & 0.17 & 0.71 & 0.49 & 0.44 \\
\hline Fat, $\%$ & $24.4^{\mathrm{b}}$ & $23.6^{\mathrm{ab}}$ & $23.3^{\mathrm{a}}$ & $23.9^{\mathrm{ab}}$ & 0.21 & 0.30 & $<0.001$ & 0.17 & 0.19 & 0.84 & 0.034 \\
\hline Ash, $\%$ & 14.1 & 14.8 & 15.0 & 14.4 & 0.22 & 0.32 & $<0.001$ & 0.009 & 0.54 & 0.93 & 0.052 \\
\hline Energy $^{4}$ & 2273 & 2230 & 2218 & 2259 & 15.0 & 21.5 & $<0.001$ & 0.011 & 0.55 & 0.96 & 0.059 \\
\hline \multicolumn{12}{|l|}{$62 \mathrm{~d}$ of age } \\
\hline Moisture, \% & 66.1 & 66.4 & 66.7 & 66.4 & 8.19 & 0.27 & $<0.001$ & 0.62 & 0.26 & 0.91 & 0.32 \\
\hline Protein, \% & 54.1 & 53.5 & 54.1 & 53.7 & 0.22 & 0.31 & $<0.001$ & 0.025 & 0.75 & 0.097 & 0.80 \\
\hline Fat, \% & 32.3 & 32.2 & 31.7 & 32.1 & 0.27 & 0.39 & $<0.001$ & 0.65 & 0.32 & 0.66 & 0.56 \\
\hline Ash, $\%$ & 11.4 & 11.8 & 12.1 & 11.8 & 0.24 & 0.34 & $<0.001$ & 0.40 & 0.26 & 0.85 & 0.33 \\
\hline Energy ${ }^{4}$ & 2520 & 2498 & 2475 & 2496 & 15.9 & 22.7 & $<0.001$ & 0.35 & 0.29 & 0.98 & 0.37 \\
\hline
\end{tabular}

${ }^{1}$ LSF_Hn-6/n-3 = Low soluble fibre_High n-6/n-3 fatty acid ratio; LSF_Ln-6/n-3 = Low soluble fibre_Low n-6/n-3 fatty acid ratio; HSF_Hn-6/n-3 = High soluble fibre_High n-6/n-3 fatty acid ratio; HSF_Ln-6/n-3 = High soluble fibre_Low n-6/n-3 fatty acid ratio. ${ }^{2}$ weight at weaning (27d) as a covariate. ${ }^{3}$ initial body corporal condition $(27 \mathrm{~d})$ as a covariate. ${ }^{4}$ gross energy, $\mathrm{kJ} / 100 \mathrm{~g} .{ }^{\mathrm{a}-\mathrm{c}}$ Fattening mean values in the same column with a different superscript differ $\mathrm{P}<0.05$. 
Table 5. Effect of level of soluble fibre type of fatty acids and age on in vivo (body and carcass) chemical composition and energy content of weaning rabbits at 27,39 and $62 \mathrm{~d}$ of age.

\begin{tabular}{|c|c|c|c|c|c|c|c|c|c|c|c|c|c|c|}
\hline \multirow[b]{2}{*}{$\mathrm{N}$} & \multicolumn{5}{|c|}{ SEM } & \multicolumn{9}{|c|}{ P-value } \\
\hline & $\begin{array}{c}\text { SF and } \\
\text { n6/n-3 } \\
109\end{array}$ & $\begin{array}{c}\mathrm{SF} \times \\
\mathrm{n}-6 / \mathrm{n}-3 \\
109\end{array}$ & $\begin{array}{l}\text { age } \\
109\end{array}$ & $\begin{array}{l}\text { SF×age and n- } \\
6 / n-3 \times \text { age }\end{array}$ & $\begin{array}{l}\text { SF } \times n-6 / n-3 \\
\quad \times \text { age }\end{array}$ & $\operatorname{Cov}^{1}$ & $\mathrm{Cov}^{2}$ & SF & $n-6 / n-3$ & $S F \times n-6 / n-3$ & Age & SF×age & $\begin{array}{c}n-6 / n-3 \times \\
\text { age }\end{array}$ & $\begin{array}{c}\text { SF } \times \text { n- } 6 / n-3 \\
\times \text { age }\end{array}$ \\
\hline Body weight, g & & & & & & $<0.001$ & & 0.98 & 0.73 & 0.92 & $<0.001$ & 0.99 & 0.048 & 0.81 \\
\hline \multicolumn{15}{|l|}{ Body composition } \\
\hline Moisture, $\%$ & 0.10 & 0.14 & 0.15 & 0.21 & 0.30 & $<0.001$ & $<0.001$ & 0.16 & 0.70 & 0.042 & $<0.001$ & 0.42 & 0.17 & 0.26 \\
\hline Protein, $\%$ & 0.12 & 0.18 & 0.14 & 0.19 & 0.28 & $<0.001$ & $<0.001$ & 0.54 & 0.57 & 0.41 & $<0.001$ & 0.53 & 0.036 & 0.61 \\
\hline Fat, \% & 0.17 & 0.25 & 0.18 & 0.26 & 0.74 & 0.17 & 0.037 & 0.37 & 0.19 & 0.45 & $<0.001$ & 0.87 & 0.015 & 0.37 \\
\hline Ash, $\%$ & 0.04 & 0.11 & 0.04 & 0.06 & 0.08 & $<0.001$ & $<0.001$ & 0.26 & 0.10 & 0.24 & $<0.001$ & 0.94 & 0.15 & 0.50 \\
\hline Energy $^{3}$ & 3.38 & 4.82 & 3.88 & 4.00 & 7.97 & 0.095 & $<0.001$ & 0.28 & 0.25 & 0.44 & $<0.001$ & 0.99 & 0.022 & 0.16 \\
\hline \multicolumn{15}{|l|}{$\begin{array}{l}\text { Carcass } \\
\text { composition }\end{array}$} \\
\hline Moisture, $\%$ & 0.22 & 0.31 & 0.27 & 0.39 & 0.55 & 0.004 & 0.41 & 0.78 & 0.28 & 0.23 & $<0.001$ & 0.50 & 0.31 & 0.29 \\
\hline Protein, $\%$ & 0.09 & 0.13 & 0.14 & 0.20 & 0.29 & $<0.001$ & $<0.001$ & 0.74 & 0.30 & 0.80 & $<0.001$ & 0.72 & 0.10 & 0.63 \\
\hline Fat, \% & 0.20 & 0.28 & 0.24 & 0.34 & 0.48 & $<0.001$ & $<0.001$ & 0.71 & 0.31 & 0.084 & $<0.001$ & 0.76 & 0.18 & 0.23 \\
\hline Ash, $\%$ & 0.13 & 0.18 & 0.16 & 0.22 & 0.31 & $<0.001$ & $<0.001$ & 0.28 & 0.58 & 0.078 & $<0.001$ & 0.82 & 0.92 & 0.41 \\
\hline Energy 1 & 8.75 & 12.5 & 10.4 & 14.8 & 21.0 & $<0.001$ & $<0.001$ & 0.31 & 0.64 & 0.10 & $<0.001$ & 0.84 & 0.86 & 0.43 \\
\hline
\end{tabular}

${ }^{1}$ weight at weaning (27d) as a covariate. ${ }^{2}$ initial body corporal condition (27d) as a covariate. ${ }^{3}$ gross energy, $\mathrm{kJ} / 100 \mathrm{~g}$ 
Table 6. Effect of dietary soluble fiber and n-6/n-3 fatty acid ratio on nitrogen balance.

\begin{tabular}{|c|c|c|c|c|c|c|c|c|c|}
\hline \multirow[b]{3}{*}{$\mathrm{N}$} & \multicolumn{4}{|c|}{ Diets $^{1}$} & \multicolumn{2}{|c|}{ SEM } & \multicolumn{3}{|c|}{ P-value ${ }^{2}$} \\
\hline & \multirow{2}{*}{$\frac{\text { LSF_Hn-6/n-3 }}{25}$} & \multirow{2}{*}{$\frac{\text { LSF_Ln-6/n-3 }}{25}$} & \multirow{2}{*}{$\begin{array}{c}\text { HSF_Hn-6/n-3 } \\
31 \\
\end{array}$} & \multirow{2}{*}{$\frac{\text { HSF_Ln-6/n-3 }}{28}$} & \multirow[t]{2}{*}{$\begin{array}{l}S F \text { and } \\
n-6 / n-3\end{array}$} & \multirow[t]{2}{*}{$\begin{array}{c}\mathrm{SF} \times \\
\mathrm{n}-6 / \mathrm{n}-3\end{array}$} & \multirow[t]{2}{*}{ SF } & \multirow[t]{2}{*}{$n-6 / n-3$} & \multirow[t]{2}{*}{$S F \times n-6 / n-3$} \\
\hline & & & & & & & & & \\
\hline \multicolumn{10}{|c|}{26 to $39 \mathrm{~d}$ of age } \\
\hline \multicolumn{10}{|c|}{ Nitrogen intake, $g / \mathrm{kg} \mathrm{BW}^{0.75} \mathrm{~d}$} \\
\hline $\mathrm{N}_{\mathrm{i}}$ & 2.614 & 2.470 & 2.429 & 2.431 & 0.046 & 0.064 & 0.086 & 0.28 & 0.26 \\
\hline $\mathrm{DN}_{\mathrm{i}}$ & 2.028 & 1.908 & 1.851 & 1.829 & 0.035 & 0.049 & 0.011 & 0.15 & 0.32 \\
\hline \multicolumn{10}{|c|}{ Nitrogen retained, $\mathrm{g} / \mathrm{kg} \mathrm{BW}^{0.75} \mathrm{~d}$} \\
\hline $\mathrm{NR}$ in vivo & 1.553 & 1.507 & 1.550 & 1.595 & 0.034 & 0.048 & 0.38 & 0.99 & 0.35 \\
\hline NR carcass & 0.923 & 0.899 & 0.916 & 0.925 & 0.030 & 0.042 & 0.81 & 0.86 & 0.69 \\
\hline \multicolumn{10}{|l|}{ Nitrogen efficiency ${ }^{1}$} \\
\hline $\mathrm{NR}$ in vivo/ $\mathrm{N}_{\mathrm{i}}$ & 0.593 & 0.630 & 0.645 & 0.653 & 0.010 & 0.015 & 0.012 & 0.13 & 0.34 \\
\hline $\mathrm{NR}$ in vivo/ $\mathrm{DN}_{\mathrm{i}}$ & 0.764 & 0.816 & 0.847 & 0.869 & 0.013 & 0.019 & $<0.001$ & 0.060 & 0.46 \\
\hline $\mathrm{NR}$ carcass $/ \mathrm{DN}_{\mathrm{i}}$ & 0.453 & 0.485 & 0.502 & 0.513 & 0.009 & 0.013 & 0.003 & 0.097 & 0.42 \\
\hline \multicolumn{10}{|c|}{ Nitrogen losses, $\mathrm{g} / \mathrm{kg} \mathrm{BW}^{0.75} \mathrm{~d}$} \\
\hline Skin and viscera & 0.631 & 0.608 & 0.635 & 0.670 & 0.027 & 0.038 & 0.39 & 0.88 & 0.45 \\
\hline Faeces & 0.578 & 0.562 & 0.565 & 0.586 & 0.013 & 0.018 & 0.77 & 0.89 & 0.31 \\
\hline Urine & 0.482 & 0.400 & 0.314 & 0.251 & 0.035 & 0.050 & 0.002 & 0.15 & 0.85 \\
\hline \multicolumn{10}{|l|}{39 to $62 \mathrm{~d}$ of age } \\
\hline \multicolumn{10}{|c|}{ Nitrogen intake, $\mathrm{g} / \mathrm{kg} \mathrm{BW}^{0.75} \cdot \mathrm{d}$} \\
\hline $\mathrm{N}_{\mathrm{i}}$ & 2.534 & 2.434 & 2.443 & 2.428 & 0.035 & 0.050 & 0.35 & 0.26 & 0.40 \\
\hline $\mathrm{DN}_{\mathrm{i}}$ & 1.966 & 1.879 & 1.863 & 1.826 & 0.027 & 0.039 & 0.046 & 0.11 & 0.52 \\
\hline Nitrogen retained, $\mathrm{g} / \mathrm{kg}$ & & & & & & & & & \\
\hline $\mathrm{NR}$ in vivo & 1.041 & 1.087 & 1.056 & 1.071 & 0.021 & 0.030 & 0.99 & 0.32 & 0.60 \\
\hline NR carcass & 0.619 & 0.641 & 0.624 & 0.622 & 0.012 & 0.018 & 0.70 & 0.56 & 0.49 \\
\hline Nitrogen efficiency $^{1}$ & & & & & & & & & \\
\hline $\mathrm{NR}$ in vivo/ $\mathrm{N}_{\mathrm{i}}$ & 0.417 & 0.440 & 0.439 & 0.439 & 0.004 & 0.007 & 0.13 & 0.094 & 0.094 \\
\hline $\mathrm{NR}$ in vivo/ $\mathrm{DN}_{\mathrm{i}}$ & 0.538 & 0.570 & 0.576 & 0.583 & 0.006 & 0.008 & 0.004 & 0.026 & 0.17 \\
\hline $\mathrm{NR}$ carcass $/ \mathrm{DN}_{\mathrm{i}}$ & 0.318 & 0.335 & 0.340 & 0.342 & 0.003 & 0.005 & 0.006 & 0.057 & 0.12 \\
\hline Nitrogen losses, $\mathrm{g} / \mathrm{kg} \mathrm{BV}$ & & & & & & & & & \\
\hline Skin and viscera & 0.422 & 0.445 & 0.433 & 0.448 & 0.012 & 0.017 & 0.67 & 0.27 & 0.84 \\
\hline Faeces & 0.568 & 0.555 & 0.582 & 0.601 & 0.008 & 0.012 & 0.015 & 0.77 & 0.18 \\
\hline Urine & 0.925 & 0.972 & 0.807 & 0.755 & 0.027 & 0.038 & 0.046 & 0.018 & 0.29 \\
\hline 26 to $62 \mathrm{~d}$ of age & & & & & & & & & \\
\hline Nitrogen intake, $\mathrm{g} / \mathrm{kg} \mathrm{BV}$ & & & & & & & & & \\
\hline $\mathrm{N}_{\mathrm{i}}$ & 2.505 & 2.390 & 2.403 & 2.383 & 0.029 & 0.041 & 0.19 & 0.11 & 0.26 \\
\hline $\mathrm{DN}_{\mathrm{i}}$ & 1.945 & 1.845 & 1.832 & 1.792 & 0.022 & 0.032 & 0.011 & 0.030 & 0.35 \\
\hline Nitrogen retained, $\mathrm{g} / \mathrm{kg} \mathrm{H}$ & & & & & & & & & \\
\hline $\mathrm{NR}$ in vivo & 1.137 & 1.158 & 1.148 & 1.167 & 0.012 & 0.018 & 0.57 & 0.26 & 0.94 \\
\hline NR carcass & 0.674 & 0.686 & 0.678 & 0.677 & 0.007 & 0.011 & 0.84 & 0.61 & 0.54 \\
\hline Nitrogen efficiency $^{1}$ & & & & & & & & & \\
\hline $\mathrm{NR}$ in vivo/ $\mathrm{N}_{\mathrm{i}}$ & 0.458 & 0.484 & 0.489 & 0.486 & 0.005 & 0.007 & 0.034 & 0.043 & 0.066 \\
\hline $\mathrm{NR}$ in vivo/ $\mathrm{DN}_{\mathrm{i}}$ & 0.590 & 0.627 & 0.636 & 0.647 & 0.006 & 0.008 & $<0.001$ & 0.008 & 0.13 \\
\hline $\mathrm{NR}$ carcass $/ \mathrm{DN}_{\mathrm{i}}$ & 0.349 & 0.370 & 0.375 & 0.379 & 0.004 & 0.005 & 0.001 & 0.017 & 0.13 \\
\hline Nitrogen losses, g/kg BV & & & & & & & & & \\
\hline Skin and viscera & 0.462 & 0.472 & 0.470 & 0.470 & 0.099 & 0.014 & 0.36 & 0.31 & 0.73 \\
\hline Faeces & 0.561 & 0.544 & 0.572 & 0.591 & 0.007 & 0.097 & 0.004 & 0.91 & 0.072 \\
\hline Urine & 0.808 & 0.687 & 0.683 & 0.624 & 0.023 & 0.033 & 0.005 & 0.006 & 0.34 \\
\hline
\end{tabular}

${ }^{1}$ LSF_Hn-6/n-3 = Low soluble fibre_High n-6/n-3 fatty acid ratio; LSF_Ln-6/n-3 = Low soluble fibre Low n-6/n-3 fatty acid ratio; HSF_Hn-6/n-3 = High soluble fibre_High n-6/n-3 fatty acid ratio; HSF_Ln-6/n-3 = High soluble fibre_Low n-6/n-3 fatty acid ratio. ${ }^{2}$ Nitrogen retained in vivo ( $/ \mathrm{gg} \mathrm{BW}{ }^{0.75}$ and day) was used as covariate for $\mathrm{NR}$ in vivo/ $\mathrm{Ni}$ and $\mathrm{NR}$ in vivo/ $\mathrm{DNi}$, while nitrogen retained in carcass $\left(\mathrm{g} / \mathrm{kg} \mathrm{BW}^{0.75}\right.$ and day) was used as covariate for NR carcass/DNi. Both covariates were significant in all cases ( $\mathrm{P}$ $<0.001) . \mathrm{N}_{\mathrm{i}}\left(\mathrm{g} \mathrm{N}_{\mathrm{i}} / \mathrm{kg} \mathrm{BW}^{0.75}\right.$ and day): Nitrogen intake. $\mathrm{DN}_{\mathrm{i}}\left(\mathrm{g} \mathrm{DN}_{\mathrm{i}} / \mathrm{kg} \mathrm{BW}^{0.75}\right.$ and day): Digestible $\mathrm{N}$ intake. NR in vivo $\left(\mathrm{g} / \mathrm{kg} \mathrm{BW}^{0.75}\right.$ and day): retained $\mathrm{N}$ in vivo. $\mathrm{NR}$ carcass ( $\mathrm{g} / \mathrm{kg} \mathrm{BW}^{0.75}$ and day): retained $\mathrm{N}$ in carcass. $\mathrm{NR} / \mathrm{N}_{\mathrm{i}}$ in vivo: In vivo $\mathrm{N}$ retention efficiency (NR in vivo/Ni). $\mathrm{NR} / \mathrm{DN}_{\mathrm{i}}$ carcass: Carcass $\mathrm{N}$ retention efficiency; ( $\mathrm{NR}$ carcass/DNi). Skin and viscera (g N/kg BW ${ }^{0.75}$ and day): (g N retained in vivo $-\mathrm{g}$ retained in carcass) $/ \mathrm{kg} \mathrm{BW}^{0.75}$ and day. Faeces $\left(\mathrm{g} / \mathrm{kg} \mathrm{BW}^{0.75}\right.$ and day): (Total N intake $\left.-\mathrm{DN}_{\mathrm{i}}\right) / \mathrm{kg} \mathrm{BW}^{0.75}$ and day. Urine (g/kg BW ${ }^{0.75}$ and day): $\left(\mathrm{DN}_{\mathrm{i}}-\mathrm{N}\right.$ Retained in carcass- $\mathrm{N}$ excreted in skin and viscera) $/ \mathrm{kg} \mathrm{BW}^{0.75}$ and day 
Table 7. Effect of dietary soluble fiber and n-6/n-3 fatty acid ratio on energy balance.

\begin{tabular}{|c|c|c|c|c|c|c|c|c|c|c|}
\hline \multirow[b]{3}{*}{$\mathrm{N}$} & \multicolumn{4}{|c|}{ Diets $^{1}$} & \multicolumn{2}{|c|}{ SEM } & \multicolumn{4}{|c|}{ P-value ${ }^{2}$} \\
\hline & \multirow{2}{*}{$\begin{array}{c}\text { LSF_Hn- } \\
6 / n-3 \\
25\end{array}$} & \multirow{2}{*}{$\begin{array}{c}\begin{array}{c}\text { LSF_Ln- } \\
6 / n-3\end{array} \\
25 \\
\end{array}$} & \multirow{2}{*}{$\begin{array}{c}\text { HSF_Hn- } \\
6 / n-3 \\
31\end{array}$} & \multirow{2}{*}{$\begin{array}{c}\text { HSF_Ln- } \\
6 / n-3 \\
28\end{array}$} & \multirow{2}{*}{$\begin{array}{c}\text { SF and } \\
\text { n-6/n- } \\
3\end{array}$} & \multirow[t]{2}{*}{$\begin{array}{c}\mathrm{SF} \times \\
n-6 / n-3\end{array}$} & \multirow[t]{2}{*}{$\operatorname{Cov}^{1}$} & \multirow[t]{2}{*}{ SF } & \multirow[t]{2}{*}{$\begin{array}{c}n-6 / n- \\
3\end{array}$} & \multirow[t]{2}{*}{$\begin{array}{c}\mathrm{SF} \times \mathrm{n}- \\
6 / \mathrm{n}-3\end{array}$} \\
\hline & & & & & & & & & & \\
\hline \multicolumn{11}{|l|}{26 to $39 \mathrm{~d}$ of age } \\
\hline \multicolumn{11}{|l|}{ Energy intake, $\mathrm{MJ} / \mathrm{kg} \mathrm{BW}^{0.75} \cdot \mathrm{d}$} \\
\hline $\mathrm{GE}_{\mathrm{i}}$ & 1.731 & 1.668 & 1.602 & 1.599 & 0.030 & 0.043 & - & 0.023 & 0.44 & 0.48 \\
\hline $\mathrm{DE}_{\mathrm{i}}$ & 1.127 & 1.075 & 1.049 & 1.052 & 0.020 & 0.028 & - & 0.074 & 0.38 & 0.33 \\
\hline \multicolumn{11}{|l|}{ Energy retained, $\mathrm{kJ} / \mathrm{kg} \mathrm{BW}{ }^{0.75} \cdot \mathrm{d}$} \\
\hline $\mathrm{ER}$ in vivo & 349 & 351 & 360 & 349 & 12.0 & 17.0 & - & 0.78 & 0.78 & 0.72 \\
\hline ER carcass & 164 & 171 & 164 & 163 & 9.58 & 13.5 & - & 0.75 & 0.81 & 0.77 \\
\hline \multicolumn{11}{|l|}{ Energy efficiency ${ }^{1}$} \\
\hline $\mathrm{ER}$ in vivo $/ \mathrm{GE}_{\mathrm{i}}$ & 0.203 & 0.214 & 0.223 & 0.225 & 0.004 & 0.005 & $<0.001$ & 0.005 & 0.22 & 0.38 \\
\hline $\mathrm{ER}$ in vivo $/ \mathrm{DE}_{\mathrm{i}}$ & 0.311 & 0.332 & 0.340 & 0.342 & 0.006 & 0.008 & $<0.001$ & 0.021 & 0.17 & 0.23 \\
\hline $\mathrm{ER}$ carcass $/ \mathrm{DE}_{\mathrm{i}}$ & 0.146 & 0.155 & 0.160 & 0.161 & 0.003 & 0.004 & $<0.001$ & 0.021 & 0.22 & 0.36 \\
\hline \multicolumn{11}{|l|}{ Energy losses, $\mathrm{MJ} / \mathrm{kg} \mathrm{BW}^{0.75} \cdot \mathrm{d}$} \\
\hline Skin and viscera, & 0.184 & 0.179 & 0.196 & 0.187 & 0.007 & 0.096 & - & 0.31 & 0.45 & 0.82 \\
\hline Faeces & 0.605 & 0.594 & 0.552 & 0.547 & 0.010 & 0.015 & - & 0.001 & 0.61 & 0.85 \\
\hline Urine + heat production & 0.777 & 0.724 & 0.690 & 0.704 & 0.021 & 0.029 & - & 0.073 & 0.51 & 0.26 \\
\hline \multicolumn{11}{|l|}{39 to $62 \mathrm{~d}$ of age } \\
\hline Energy intake, $\mathrm{MJ} / \mathrm{kg} \mathrm{BW}^{0.75} \mathrm{c}$ & & & & & & & & & & \\
\hline $\mathrm{GE}_{\mathrm{i}}$ & 1.678 & 1.644 & 1.614 & 1.598 & 0.024 & 0.033 & - & 0.10 & 0.45 & 0.79 \\
\hline $\mathrm{DE}_{\mathrm{i}}$ & 1.093 & 1.057 & 1.057 & 1.051 & 0.015 & 0.021 & - & 0.33 & 0.34 & 0.48 \\
\hline Energy retained, $\mathrm{kJ} / \mathrm{kg} \mathrm{BW} W^{0.75}$ & & & & & & & & & & \\
\hline ER in vivo & 313 & 341 & 323 & 330 & 6.42 & 9.09 & - & 0.96 & 0.057 & 0.24 \\
\hline ER carcass & 202 & 218 & 207 & 208 & 4.13 & 5.84 & - & 0.70 & 0.16 & 0.20 \\
\hline Energy efficiency ${ }^{1}$ & & & & & & & & & & \\
\hline $\mathrm{ER}$ in vivo $/ \mathrm{GE}_{\mathrm{i}}$ & 0.193 & 0.201 & 0.205 & 0.205 & 0.002 & 0.003 & $<0.001$ & 0.012 & 0.17 & 0.25 \\
\hline $\mathrm{ER}$ in vivo $/ \mathrm{DE}_{\mathrm{i}}$ & 0.296 & 0.312 & 0.313 & 0.312 & 0.003 & 0.005 & $<0.001$ & 0.10 & 0.12 & 0.098 \\
\hline ER carcass $/ \mathrm{DE}_{\mathrm{i}}$ & 0.190 & 0.199 & 0.200 & 0.198 & 0.002 & 0.003 & $<0.001$ & 0.13 & 0.19 & 0.077 \\
\hline Energy losses, MJ/ kg BW ${ }^{0.75}$ & & & & & & & & & & \\
\hline Skin and viscera, & 0.111 & 0.124 & 0.116 & 0.122 & 0.003 & 0.004 & - & 0.63 & 0.039 & 0.42 \\
\hline Faeces & 0.585 & 0.585 & 0.557 & 0.546 & 0.008 & 0.012 & - & 0.005 & 0.64 & 0.67 \\
\hline Urine + heat production & 0.779 & 0.717 & 0.734 & 0.721 & 0.015 & 0.021 & - & 0.34 & 0.083 & 0.26 \\
\hline 26 to $62 \mathrm{~d}$ of age & & & & & & & & & & \\
\hline Energy intake, $\mathrm{MJ} / \mathrm{kg} \mathrm{BW} \mathrm{W}^{0.75}$ & & & & & & & & & & \\
\hline $\mathrm{GE}_{\mathrm{i}}$ & 1.660 & 1.614 & 1.586 & 1.568 & 0.019 & 0.027 & - & 0.033 & 0.25 & 0.62 \\
\hline $\mathrm{DE}_{\mathrm{i}}$ & 1.080 & 1.039 & 1.039 & 1.032 & 0.012 & 0.017 & - & 0.17 & 0.19 & 0.33 \\
\hline Energy retained, $\mathrm{kJ} / \mathrm{kg} \mathrm{BW} \mathrm{BW}^{0.75}$. & & & & & & & & & & \\
\hline ER in vivo & 316 & 337 & 326 & 328 & 5.23 & 7.40 & - & 0.90 & 0.13 & 0.21 \\
\hline ER carcass & 190 & 203 & 194 & 194 & 3.50 & 4.95 & - & 0.61 & 0.18 & 0.19 \\
\hline Energy efficiency ${ }^{1}$ & & & & & & & & & & \\
\hline $\mathrm{ER}$ in vivo $/ \mathrm{GE}_{\mathrm{i}}$ & 0.196 & 0.204 & 0.208 & 0.209 & 0.002 & 0.003 & $<0.001$ & 0.002 & 0.12 & 0.21 \\
\hline $\mathrm{ER}$ in vivo $/ \mathrm{DE}_{\mathrm{i}}$ & 0.301 & 0.317 & 0.318 & 0.318 & 0.003 & 0.004 & $<0.001$ & 0.032 & 0.074 & 0.069 \\
\hline ER carcass $/ \mathrm{DE}_{\mathrm{i}}$ & 0.180 & 0.189 & 0.190 & 0.190 & 0.002 & 0.003 & $<0.001$ & 0.042 & 0.088 & 0.071 \\
\hline Energy losses, MJ/ kg BW 0.75 & & & & & & & & & & \\
\hline Skin and viscera, & 0.126 & 0.133 & 0.132 & 0.134 & 0.002 & 0.003 & - & 0.32 & 0.18 & 0.44 \\
\hline Faeces & 0.579 & 0.574 & 0.547 & 0.536 & 0.007 & 0.009 & - & $<0.001$ & 0.41 & 0.73 \\
\hline Urine + heat production & 0.764 & 0.703 & 0.713 & 0.703 & 0.012 & 0.018 & - & 0.17 & 0.058 & 0.16 \\
\hline
\end{tabular}

${ }^{1}$ LSF_Hn-6/n-3 = Low soluble fibre_High n-6/n-3 fatty acid ratio; LSF_Ln-6/n-3 = Low soluble fibre_Low n-6/n-3 fatty acid ratio; HSF_Hn-6/n-3 = High soluble fibre_High n-6/n-3 fatty acid ratio; HSF_Ln-6/n-3 = High soluble fibre_Low n-6/n-3 fatty acid ratio. ${ }^{2}$ Energy retained in vivo $\left(\mathrm{kJ} / \mathrm{kg} \mathrm{BW}{ }^{0.75}\right.$ and day) as a covariate for energy efficiency in vivo and energy retained in carcass $(\mathrm{kJ} / \mathrm{kg}$ $\mathrm{BW}^{0.75}$ and day) as a covariate for energy efficiency in carcass. $\mathrm{GE}_{\mathrm{i}}$ : Gross Energy intake $\left(\mathrm{MJ} / \mathrm{kg} \mathrm{BW} \mathrm{BW}^{0.75}\right.$ and day). DE $\mathrm{DE}_{\mathrm{i}}$ : Digestible Energy intake (MJ/ kg BW ${ }^{0.75}$ and day). ER in vivo $\left(\mathrm{kJ} / \mathrm{kg} \mathrm{BW}^{0.75}\right.$ and day): EB retained in vivo. ER carcass $\left(\mathrm{kJ} / \mathrm{kg} \mathrm{BW} \mathrm{BW}^{0.75}\right.$ and day): $\mathrm{GE}$ retained in carcass. ER/GE $\mathrm{G}_{\mathrm{i}}$ in vivo: In vivo energy retention efficiency (RE in vivo/GE $\mathrm{G}_{\mathrm{i}}$. ER/DE $\mathrm{E}_{\mathrm{i}}$ carcass: Carcass energy retention efficiency (ER carcass-DE $\mathrm{D}_{\mathrm{i}}$ ). Skin and viscera $\left(\mathrm{MJ} / \mathrm{kg} \mathrm{BW}^{0.75}\right.$ and day): (MJ GE retained in vivo - $\mathrm{MJ} \mathrm{GE}$ retained in carcass $) / \mathrm{kg} \mathrm{BW}^{0.75}$ and day. Faeces $\left(\mathrm{MJ} / \mathrm{kg} \mathrm{BW}{ }^{0.75}\right.$ and day): $\left(\mathrm{GE}_{\mathrm{i}}-\mathrm{DE}_{\mathrm{i}}\right) / \mathrm{Kg} \mathrm{BW}^{0.75}$ and day. Urine + heat production $\left(\mathrm{MJ} / \mathrm{kg} \mathrm{BW} \mathrm{BW}^{0.75}\right.$ and day): (DE - GE retained in carcass- GE excreted in skin and viscera) $/ \mathrm{kg} \mathrm{BW}^{0.75}$ and day. 

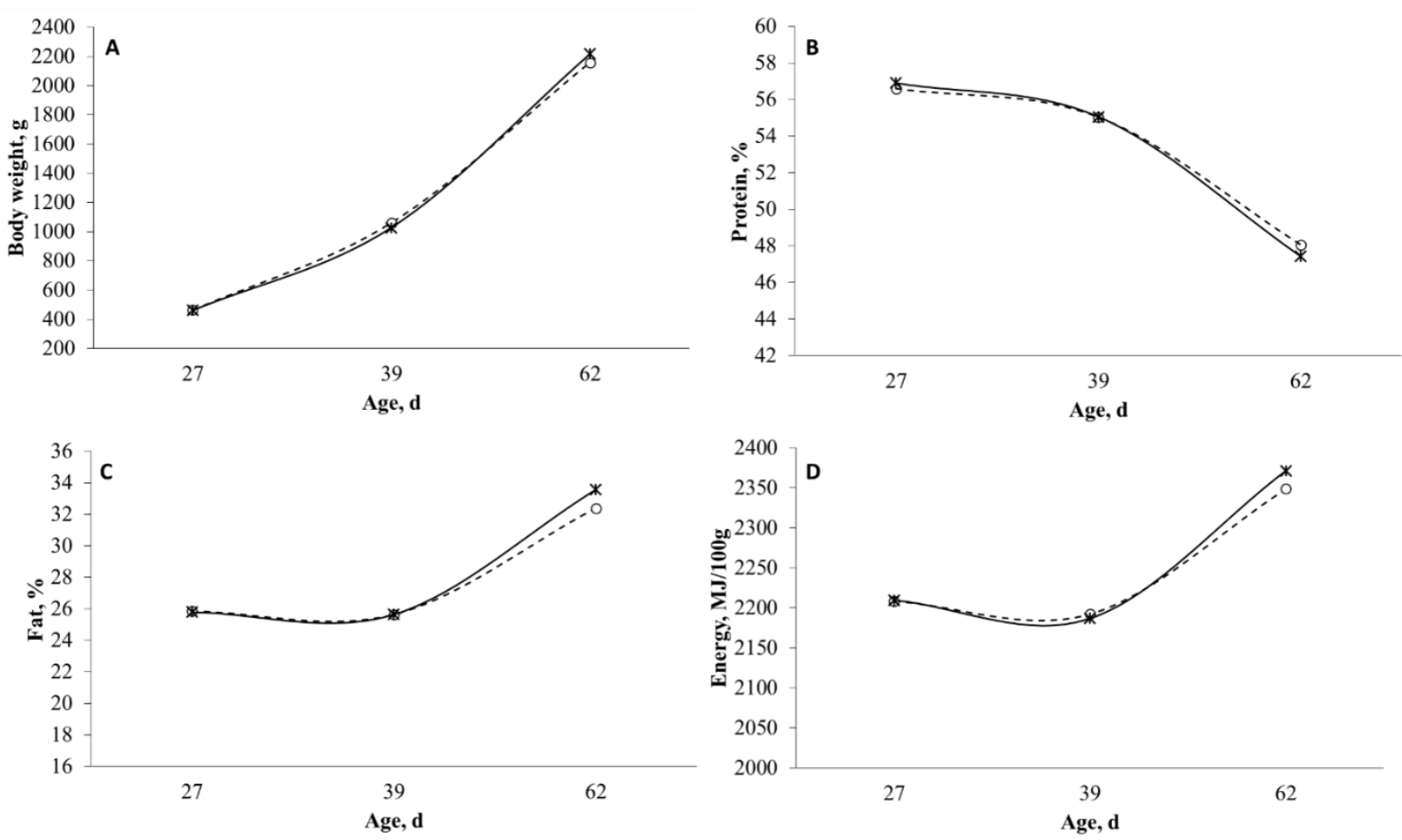

Figure 1. Effect of fatty acids level over time (27, 39 and $62 \mathrm{~d}$ of age) on body chemical composition, energy content and body weight of rabbit [Hn-6/n-3 $\circ(n=56) ;$ Ln-6/n-3 * $(\mathrm{n}=53) ; \mathrm{P}_{\text {Body weight }}=0.048 ; \mathrm{P}_{\text {Protein }}=0.036$ and $\mathrm{P}_{\text {Fat }}=0.015$ and $\left.\mathrm{P}_{\text {Energy }}=0.022\right]$. 


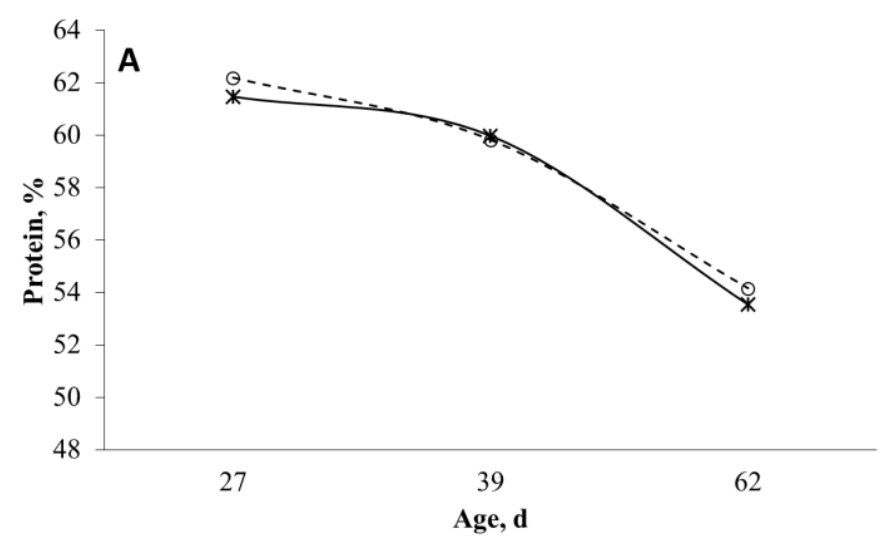

Figure 2. Effect of fatty acids level over time (27, 39 and $62 \mathrm{~d}$ of age) on carcass protein composition, [Hn-6/n-3 $\left.\circ(\mathrm{n}=56) ; \mathrm{Ln}-6 / \mathrm{n}-3 *(\mathrm{n}=53) ; \mathrm{P}_{\text {Protein }}=0.097\right]$. 


\subsection{Effect of dietary soluble fibre level and n-6/n-3 fatty acid ratio on digestion and intestinal health in growing rabbits.}

\subsubsection{Introduction.}

Reducing mortality in young rabbits caused by digestive disturbances such as epizootic rabbit enteropathy (ERE) and improving performance and immune response can be achieved by dietary means. Among nutritional strategies the most relevant one seems to be the reduction of the ileal flow of crude protein by selecting the appropriate dietary source (Gutiérrez et al., 2003) or by reducing the dietary level of crude protein (Chamorro et al., 2007). Also, the type of starch and its processing, i.e. the use of wheat instead of peas, or the increase in dietary soluble fibre have been proven to be positive nutritional interventions to reduce digestive related diseases (Gutiérrez et al., 2002; Gómez-Conde et al., 2007, 2009). Combinations of these factors have been also studied in farms with a high mortality caused by ERE and it was observed that the increase of the dietary soluble and insoluble fibre combined with the reduction of the dietary crude protein improved the health status of the rabbits (Martínez-Vallespín et al., 2011; Xiccato et al., 2011; Gidenne et al., 2013). Another strategy that showed positive effects on rabbit health is the restriction of feed intake after weaning (Gidenne et al., 2012). However, none of these options, or their combination, seems to be able to control completely the digestive disturbances and reduce mortality below $10 \%$ in the long term. Accordingly, it remains important to look for additional nutritional factors that may interact positively with those commented in order to decrease mortality after weaning.

There is wide evidence on the effects of the dietary fat on the immune system (Calder, 2003). Dietary lipids are sources of essential polyunsaturated fatty acids (PUFA) linoleic acid (LA, 18:2n-6) and linolenic acid (ALA,18:3n-3) that are precursors of the long chain PUFA arachidonic acid (AA, 20:4n-6), eicosapentaenoic acid (EPA, 20:5n-3) and docosahexaenoic acid (DHA, 22:6n-3) which are important components of membrane phospholipids being AA a major fatty acid component in immune cells (Calder, 2003; Harbige, 2003). Therefore, the dietary lipid source has a direct impact on the immune cells composition and function (Calder, 2003; Harbige, 2003). However, lipid effects on immune response are largely variable given the antagonistic effects of both fatty acid series n- 6 and n-3 on inflammatory processes (Anderson et al., 2002). It seems that a well-balanced dietary $n-6 / n-3$ ratio is needed to ensure an optimal immune 
response against pathogens (Harbige, 2003). In this regard, Maertens et al. (2005) in an experimental farm naturally affected by ERE reported a decrease of mortality in rabbits weaned from does fed an n-3 rich diet and fed the n-3 rich diet after weaning (n-6/n-3, ratio $=1.0$, obtained with extruded linseed), compared with a control diet $(n-6 / n-3$, ratio= 4.8). A similar positive effect on mortality was reported by Casado et al. (2013), when decreased the $n-6 / n-3$ ratio from 5.9 to 0.8 using linseed oil. It might be related to the enhanced immune status in rabbits fed linseed oil than in those fed hydrogenated soybean oil, safflower oil or menhaden oil (Kelley et al., 1988).

The aim of this study was to evaluate whether the reduction of the ratio $n-6 / n-3$ improves rabbit digestive function and health and exert a synergistic effect with soluble fibre. To this end four consecutive trials were performed in a farm naturally affected by ERE. Two of them designed to determine dietary effects on digestibility, gut function and immune related genes, and another two to test the effect of feeding the experimental diets pre- and post-weaning or only pre-weaning on mortality rates.

\subsubsection{Materials and methods.}

\subsubsection{Animals and housing.}

Crossbred hybrid healthy mixed-sex rabbits (New Zealand White $\times$ Californian, $\mathrm{V}$ $\times \mathrm{R}$ from UPV, Valencia, Spain) from multiparous rabbit does, weaned at $26 \mathrm{~d}$ of age obtained from a farm affected by Epizootic Rabbit Enteropathy were used in all the experiments. In trials 1, 2 and 4 rabbits were housed collectively in groups of 2, 3 or 4 animals per cage. In trial 3 rabbits were housed individually in metabolism cages throughout the trial. Rabbits were kept under controlled environmental conditions (18$23^{\circ} \mathrm{C}$ and $12 \mathrm{~h}$ light: dark cycle lighting, 07:00-19:00 h) and had free access to feed and water at any time. All procedures involving animals were carried out in accordance with the Spanish guidelines for experimental animal protection (Royal Decree 53/2013 of February 1st on the protection of animals used for experimentation or other scientific purposes) after being approved by the Animal Ethics Committee of the Universidad Politécnica de Madrid. 
4.3.2.2. Trial 1. Mortality trial in collective cages with the experimental diets fed pre and post-weaning.

Five hundred and seventeen rabbits were housed into 185 cages in groups of 2 or 3 rabbits per cage. They were fed with the experimental diets from 26 (weaning) to $39 \mathrm{~d}$ of age. Both mothers and their litters received the same experimental diet. From 39 to $54 \mathrm{~d}$ of age they all were fed with the same commercial diet (169 g CP, $463 \mathrm{~g}$ TDF, $384 \mathrm{~g}$ aNDFom-cp, 42.9 ADL and 79.0 soluble fibre per kg DM). Mortality was monitored throughout the trial.

\subsubsection{Trial 2. Mortality trial in collective cages with the experimental diets fed only} pre-weaning.

Eight hundred and fifty-three rabbits were housed into 286 cages in groups of 2 or 3 rabbits per cage. The mothers and their litters were fed the same experimental diets but after weaning rabbits were fed during all the fattening period (25-56 d of age) with the same commercial diet than in the previous experiment. Mortality was monitored throughout the trial.

\subsubsection{Trial 3: Faecal digestibility and soft faeces excretion.}

Fifty-six weanling mixed-sex rabbits (14/diet) of $26 \mathrm{~d}$ of age, with a BW of $449 \pm$ $54 \mathrm{~g}$ (mean \pm standard deviation) were used to determine the apparent faecal digestibility of DM, CP, ether extract, starch, gross energy, total dietary fibre (TDF), aNDFom-cp (aNDFom corrected for crude protein) and soluble fibre (estimated as: TDF-aNDFomcp). Faecal mucin content was determined to correct the faecal TDF value (Abad et al., 2013 and 2015). Both mothers and their litters received the same experimental diet. Rabbits were placed individually in metabolism cages and from 39 to $42 \mathrm{~d}$ of age, DM intake and total faecal output were recorded according to the method of Gómez-Conde et al. (2007). Faeces produced daily were collected in labeled polyethylene bags and stored at $-20^{\circ} \mathrm{C}$, dried at $80^{\circ} \mathrm{C}$ for $48 \mathrm{~h}$ and ground to $1 \mathrm{~mm}$ for further analysis.

At $42 \mathrm{~d}$ of age, a plastic collar were put around the neck at 8:00 for 24 hs in 48 rabbits of this group (12/treatment) to collect individually the soft faeces excreted. Faeces were collected at 12 and $24 \mathrm{~h}$ and were stored at $-20^{\circ} \mathrm{C}$ and freeze- dried to analyze $\mathrm{CP}$ and estimated the recycled protein. 


\subsubsection{Trial 4: Ileal digestibility, digestive traits, sucrose activity and immune} function.

Two-hundred eight rabbits (56/treatment), $26 \mathrm{~d}$ in age, and a BW of $422 \pm 27.4 \mathrm{~g}$, were caged in groups of 3 ( 8 cages) or 4 rabbits ( 8 cages). Both mothers and their litters received the same experimental diet. Rabbits were fed the experimental diets from 25 to $39 \mathrm{~d}$ of age and mortality was recorded. At $39 \mathrm{~d}$ of age all the rabbits were slaughtered by $\mathrm{CO}_{2}$ inhalation between 19:00 and 22:00 h, to minimize the influence of caecotrophy. The whole gastrointestinal tract, stomach, caecum and liver were removed and weighed and caecal $\mathrm{pH}$ measured. Six $6 \mathrm{~cm}$ samples were excised from the middle part of the jejunum from 40 of the slaughtered rabbits and flushed with saline solution, frozen in dry ice, and immediately stored at $-20^{\circ} \mathrm{C}$ to determine sucrose activity (10/treatment). The caudal $20 \mathrm{~cm}$ of the ileum was excised, emptied, and the ileal digesta frozen, freeze-dried, and ground to determine the apparent ileal digestibility of DM, starch and TDF. Due to the small quantities of sample, ileal digesta from 4 to 5 rabbits for each treatment were pooled, resulting in 9-11 samples/treatment. The ileal digestibility of DM and starch was determined by the dilution technique using ytterbium as a marker (Gómez-Conde et al., 2007). Once done these determinations, a fixed amount of ileal digesta of each single pool was mixed in one pool per treatment to analyze TDF and ileal mucin content to determine their apparent ileal digestibility (Abad-Guamán et al., 2013 and 2015). The ileal flow of DM, starch and TDF was calculated by multiplying the apparent ileal digestibilities obtained for each pool of samples and the average daily intake of DM, starch and TDF recorded for the corresponding animals.

Segments of $3 \mathrm{~cm}$ of ileum between the ileo-caecal valve and the first Peyer's patch, and $2 \mathrm{~cm}$ of the last section of the appendix were collected in 32 rabbits (8/treatment) to analyze the expression of immune related genes. They were cleaned with saline solution $(\mathrm{NaCl} 0.9 \%)$ cut longitudinally and scraped, to obtain approximately $50 \mathrm{mg}$ of mucosa, and stored in vials containing $1 \mathrm{ml}$ of RNA preserving solution (RNA later, Ambion) and frozen at $-80^{\circ} \mathrm{C}$.

Total RNA from intestinal mucosal scrapings and appendix were extracted and first strand cDNA synthesized as previously described by Ipharraguerre et al. (2013). Approximately $2 \mu \mathrm{g}$ of RNA with an average A260/A280 of 1.9 were retrotranscribed. Primers and optimal PCR conditions for glyceraldehyde-3 phosphate (GADPH) and hipoxantine-guanine phosphoriltransferase (HPRT) (housekeepings), interleukin 10 (IL- 
10) and interferon-gamma (IFN- $\gamma$ ) were taken from Godornes et al. (2007) and Chamorro el al. (2010). Those for TLR-2, TLR-4 Chen et al. 2014, MUC-1 and MUC-13 were taken from Bäuerl et al. (2014). Primers for IL-2, IL-6, IL-8 and the inductible nitric oxide synthase (iNOS) were designed by us using Primer Express ${ }^{\circledR}$ v.2 (Applied Biosystems, Foster City, CA, USA) (Table 3). Each reaction mix consisted on around $100 \mathrm{ng}$ of first strand cDNA as a template, specific primers, ultra-purified water and SYBR ${ }^{\circ}$ Green Master Mix (Applied Biosystems Foster City, CA, USA) as fluorescent DNA intercalating agent. All samples were run in triplicate and quantified by normalizing the cytokine signal of GADPH and HPRT.

\subsubsection{Chemical analysis.}

Procedures of the AOAC (2000) were used to determine DM (method 934.01), ash (method 942.05), CP (method 968.06), ether extract (920.39), starch (amyloglucosidase$\alpha$-amylase method; method 996.11), and total dietary fibre (985.29). Sugars were analyzed according to Yemm and Willis (1954). Dietary NDF was determined using the filter bag system (Ankom Technology, New York) according to Mertens et al. (2002), and a thermo-stable amylase without any sodium sulphite added. It was corrected for its own ash and protein as indicated for total dietary fibre. Dietary ADF and ADL were analyzed according Goering and Van Soest (1970). The soluble fibre was calculated by difference as TDF-NDF. Gross energy was determined by adiabatic calorimetry. Dietary fatty acids of experimental diets were extracted and quantified by the one-step procedure described by Sukhija and Palmquist (1988) in lyophilised samples. Gas chromatography analysis and conditions were as described elsewhere (Daza et al., 2007) using a 6890 Hewlett Packard gas chromatograph and a $30 \mathrm{~m} \times 0.3 \mathrm{~mm} \times 0.25 \mathrm{~m}$ cross-linked polyethylene glycol capillary column. Diets were analyzed in triplicate, and ileal digesta and faeces were analyzed in duplicate. Crude mucin was determined according to the method of precipitation with ethanol as described by Leterme et al. (1998) and Romero et al. (2011), and using pectinase (Sigma P2401) to remove soluble fibre as described by (Abad et al., 2013). One gram of ileal content and three grams of faeces were used to determine crude mucin. Besides, ytterbium content of diets and ileal digesta were assessed by atomic absorption spectrometry (Smith Hieftje 22, Thermo Jarrel Ash, MA) (García et al., 1999). 


\subsubsection{Statistical analysis.}

Results of the apparent faecal and ileal digestibility, digestive traits, sucrose activity and soft faeces were analyzed using a mixed model that included as fixed effects the level of soluble fibre, the ratio $n-6 / n-3$, and their interactions. When interactions were significant $(\mathrm{P}<0.05)$ comparisons among all the treatment means were made using a $\mathrm{t}-$ test. Mortality was analyzed using a logistic regression (GENMOD procedure of SAS considering a binomial distribution) including in the model the level of soluble fibre, the ratio $n-6 / n-3$, and their interactions and the results were transformed from the logit scale. Also, differences in gene expression were determined using a mixed model in which was included as fixed effects the level of soluble fibre, the ratio $n-6 / n-3$, and their interactions and the sample as a random effect (Steibel et al., 2009). For genes displaying efficiencies different from 2 ( $E \neq 2), C t$ values were adjusted according to the model described by Steibel et al. (2009).

\subsubsection{Results.}

In trial 1 mortality caused by ERE was on average $24.5 \%$ in animals fed with experimental diets from 25 to $39 \mathrm{~d}$ of age and the commercial diet from 39 to $54 \mathrm{~d}$ of age. A significant reduction on mortality (by 26\%; $\mathrm{P}=0.04$ ), was observed in rabbits fed the HSF diets (Table 2). In trial 2 mortality caused by ERE was on average $34.7 \%$ and no significant differences were observed among rabbits fed with the experimental diets before weaning and a commercial diet during all the fattening period. Finally, the average mortality caused by ERE from 25 to $39 \mathrm{~d}$ of age in trial 4 was $8.1 \%$ (Table 2). Mortality rates were lower (by 87\%; $\mathrm{P}<0.001$ ) in rabbits fed with HSF diets respect to those fed with LSF diets.

No significant differences were observed on body weight or weight gain at $39 \mathrm{~d}$ of age (Trial 4, Table 3). However, feed intake decreased by $8 \%$ in rabbits fed with HSF diets (Trial 4, $\mathrm{P}=0.012$ ) from 26 to $39 \mathrm{~d}$ of age and tended to decrease from 39 to $42 \mathrm{~d}$ of age (Trial 3, $\mathrm{P}=0.099$; Table 5), while the $\mathrm{n}-6 / \mathrm{n}-3$ ratio did not influence feed intake. A significant improvement on feed efficiency was observed in rabbits fed the HSF diets (Trial 4, P = 0.05; Table 5). Treatments did not affect ileal and faecal DM digestibility (48.7 and $64.2 \%$ on average, respectively; Tables 4 and 5). The increase of soluble fibre in the diet doubled the TDF ileal digestibility (12.8 vs. $25.3 \%)$ and increased its faecal digestibility by $40 \%$ (29.9 vs. $42.0 \% ; \mathrm{P} \leq 0.029)$. It was accounted for the increase of both 
faecal NDF and soluble fibre digestibility in rabbits fed HSF diets (26.6 vs. $32.9 \%$ and 44.2 vs. $63.5 \%$, respectively; $\mathrm{P}<0.001)$.

The increase of soluble fibre tended to improve the ileal digestibility of starch, reducing the ileal starch flow $(\mathrm{P} \leq 0.064)$ but impaired its faecal digestibility $(99.1$ vs. 98.6; $\mathrm{P}<0.001$ ) (Tables 4 and 5). The reduction of the $\mathrm{n}-6 / \mathrm{n}-3$ ratio in the diet, decreased the faecal digestibility of the total dietary fibre and soluble fibre in LSF group but no effect was observed in HSF fed rabbits $(\mathrm{P} \leq 0.028)$. The faecal digestibility of fat increased by $3 \%$ in rabbits fed diets with the low $n-6 / n-3$ ratio $(79.0$ vs. $81.5 \% ; \mathrm{P}=0.043)$. The increase of soluble fibre increased by $17 \%$ the ileal flow of crude mucins $(\mathrm{P}=0.043)$, with no effect on faecal mucin excretion. Protein content in jejunal mucosa decreased in rabbits fed Ln-6/n-3 diets (71.8 vs. $63.3 \mathrm{mg}$ protein/g tissue, $\mathrm{P}=0.026, \mathrm{SEM}=3.68$ ), while the saccharidase specific activity tended to increase in rabbits fed with HSF_Hn6/n-3 diet compared the other three groups (406 vs. $322 \mu$ mol glucose/g protein. $\mathrm{P}=$ 0.068. $\mathrm{SEM}=32.0$. (Data not shown).

Rabbits fed with LSF_Ln-6/n-3 decreased by $10 \%$ their total digestive tract $(\mathrm{P}=$ 0.001; expressed as \% BW) (Trial 4, Table 6), due to the trend to reduce stomach and caecum weights $(\mathrm{P} \leq 0.063)$ respect to rabbits fed with LSF_Hn-6/n-3 diet. The relative weight of the liver of rabbits fed HSF diets decreased by $6 \%$ compared with those fed LSF diets $(\mathrm{P}=0.030)$ (Trial 4, Table 6). Caecal $\mathrm{pH}$ was $10 \%$ higher in rabbits fed LSF_Hn-6/n-3 diet compared with the other three groups $(\mathrm{P}<0.001)$. Soft faeces excretion at $42 \mathrm{~d}$ of age decreased by $6 \%$ in rabbits fed with HSF diets (31.0 vs. $29.2 \mathrm{~g}$ $\mathrm{DM} / \mathrm{d} ; \mathrm{P}=0.037$. Trial 3, Table 7), but their soft faeces contained a 7\% more protein than those fed LSF diet (30.2 vs. $27.7 \% ; \mathrm{P}=0.015)$ and the reduction of the $\mathrm{n}-6 / \mathrm{n}-3$ ratio tended to increase the CP content in soft faeces when combined with HSF diet $(\mathrm{P}=0.11)$. It resulted in a trend to increase protein recycled through caecotrophy in rabbits fed HSF_Ln-6/n-3 diet compared with HSF_Hn-6/n-3 (P = 0.092).

The level SF and n-6/n-3 ratio had a minor influence on the gene expression of immune related genes in the appendix (Table 8). In the appendix a significant interaction $(\mathrm{P}=0.04)$ between SF and $n-6 / n-3$ ratio was observed for IL-8 with a down-regulation of this chemokine in rabbits fed the Ln-6/n-3 diet in LSF groups having no such effect in those fed the HSF. The expression of IL- 6 tended $(\mathrm{P}=0.09)$ to show a similar interaction. Also, the expression of TLR-4 significantly decreased $(\mathrm{P}=0.03)$ in rabbits fed the Ln6/n-3 diets. Rabbits fed HSF diets showed a higher ileal MUC-13 gene expression ( $\mathrm{P}=$ 
0.046) and lower ileal iNOS gene expression $(\mathrm{P}=0.050)$ than those fed LSF diets. In contrast, the reduction of the $n-6 / n-3$ ratio increased the ileal gene expression of IL2, IL10, IFN- $\gamma$ and TLR-2 $(\mathrm{P} \leq 0.028)$.

\subsubsection{Discussion.}

Nutritional strategies have been shown to decrease mortality rates in young rabbits after weaning caused by ERE. Among them, the use of an adequate fibre source and level, and the inclusion of n-3 in rabbit diets have been previously shown to reduce mortality (Maertens et al., 2005; Gómez-Conde et al., 2007, 2009; Trocino et al., 2013a). In the present study (trial 4) we were able to confirm that diets with an increased level of SF (around 12\%) can be used to reduce mortality caused by ERE after weaning (Trocino et al., 2013a). This level of SF seems to be especially required in the post weaning period from 25 to $39 \mathrm{~d}$ of age, because the effect was not maintained in time when rabbits were fed the experimental diets throughout the fattening period (Delgado et al., 2015a). Moreover, feeding the SF from 25 to $39 \mathrm{~d}$ of age and then a commercial diet (trial 1) was enough to maintain the positive effect on mortality during the fattening period. By contrast, only feeding this level of SF during lactation (through the maternal diet) it is not enough to have the desired effects after weaning (trial 2). This was somehow unexpected given the positive effect of dietary SF and n-6/n-3 fatty acid ratio LSF_Ln-6/n-3 and HSF_Hn-67n-3on growth performance of suckling kits and milk characteristics (Delgado et al., 2015b and Chapter 4.1). Therefore, the present study stresses the important influence of post-weaning diets on rabbit health that might be related to the important changes and evolution observed in the caecal microbiota after weaning (Delgado et al., submitted; Chapter1).

The reduction of dietary n-6/n-3 fatty acid ratio by increasing C18:3n-3 levels caused no effects on mortality. This is in contrast to observed by Maertens et al. (2005) who reported a reduced mortality in rabbits fed diets with a n-6/n-3 ratio of $1: 1$ compared to those fed a ratio 4:1 after weaning. In the study of Maertens et al. (2005) the increase of dietary n-3 was at expenses of reducing C18:2n-6, while in our study C18:2n-6 concentration was maintained among diets and therefore the effects are directly related to changes in the $n-3$ concentration. Also, differences between the concentrations of dietary C18:3n-3 in both studies, $34 \%$ vs. $13 \%$ in Martens et al. (2005) and the current study respectively, might be behind the different results obtained in mortality. Therefore, it is 
plausible that the beneficial effects of $n-3$ on mortality might be as a result of a substantial reduction of $\mathrm{C} 18: 2 \mathrm{n}-6$ counterbalanced with higher $\mathrm{C} 18: 3 \mathrm{n}-3$ concentrations, more than simply increase dietary $n-3$ inclusion level. No interactions between the $n-6 / n-3$ ratio and SF were observed on mortality rates.

The positive effects of dietary SF on mortality during the fattening period might be related to modifications occurred in the gut function and/or microbiota profile (Carabaño et al., 2008). In this regard, better feed efficiency together with improvements on ileal starch digestibility and a significant reduction of the ileal starch flow were also observed in rabbits fed the high SF diets. The increase of ileal starch digestibility is indicative of an enhanced functionality in the small intestine (Gómez-Conde et al., 2007) although it might be also related to the slight reduction of standard level in HSF diets. Moreover, the level of soluble fibre increased the ileal flow of mucins as previously described in adult rabbits (Abad-Guamán et al., 2015). This agrees with the higher number of goblet cells per villi found in the jejunum when the soluble fibre is increased in rabbits (El Abed et al., 2011) and rats (Ito et al., 2009). Mucins play an important role on intestinal protection acting as a physical and chemical barrier to microorganisms and interacting with the immune system (McGuckin et al., 2011; Sheng et al., 2013). In the gastrointestinal tract transmembrane mucins are expressed by epithelial cells and although their functions remain to be elucidated they seem to be more involved in enterocyte sensing and signaling compared to the gel forming ones (Johanson et al., 2013). In this regard, it has been reported the immunodulatory action of transmembrane mucins MUC-1 and MUC-13 and their reciprocal role to control intestinal immune homeostasis (Sheng et al., 2013). MUC1 plays an anti-inflammatory role and MUC-13 the pro-inflammatory one and the disruption or abnormal expression of both make the intestinal epithelium more susceptible to infection and disease (Sheng et al. 2013). According to this, Bäuerl et al. (2014) showed significantly higher MUC-1 and MUC-13 expression in the appendix and caeca of rabbits affected by ERE compared to the healthy ones. In the present study, in apparently healthy rabbits, no significant differences in the expression of both mucins were observed in the appendix. However, in the ileum MUC-13 was down-regulated in rabbits fed the high SF diets coincident with a lower expression of the pro-inflammatory iNOS and a lack of effect on MUC-1 and the pro- and anti-inflammatory interleukins tested. If the beneficial effects of SF in a context of ERE can be partly explained by its 
contribution to a better immune homeostasis in the enterocyte through MUC-13 remains to be tested under controlled conditions of the disease and merits further research.

The increase of dietary SF using sugar beet pulp improved the faecal digestibility of insoluble (NDF) and soluble (TDF-NDF) fractions as expected (Trocino et al., 2011; Xiccato et al., 2011). Also, SF exerted improved ileal TDF digestibility. This result obtained with young rabbits is similar to that found in adult-canulated does by AbadGuamán et al. (2015). The increase of the fermentative activity in the ileum and caecum might imply a modification of the microbiota profile with positive implications on the intestinal health (Gómez-Conde et al., 2007). Also, important metabolic implications were observed in rabbits fed the HSF diets showing a decreased relative liver weight. This is in agreement with previous studies (Falcao e-Cunha et al., 2004;Papadomichelakis et al., 2012; Pascual et al., 2014; Tazzoli et al., 2015). Papadomichelakis et al., (2012) found a reduction of the liver relative weight together with reduced hepatic glycogen and cholesterol concentrations in rabbits fed diets rich in soluble and insoluble fibre. Authors explained the observed effects because of the inhibition of cholesterol absorption and increased faecal excretion of bile acids and/or to the lower postprandial glucose levels due to the lower starch level when fermentable fibre increased (Papadomichelakis et al,. 2012).

The increase of the fermentative activity in the caecum agrees with the reduction of urine nitrogen excretion (Delgado et al., 2015a; Chapter 4.2) and the increase of protein content of soft faces in HSF fed rabbits, although the daily recycled protein through caecotrophy was not affected due to the lower soft faeces excretion of HSF fed rabbits. On the other hand, a lower faecal digestibility of protein and starch were observed in HSF fed rabbits. This might be explained by the fact that sugar beet pulp inclusion usually increases the caecal relative weight (Gómez-Conde et al., 2009) although its mean retention time in the caecum is not increased (Gidenne et al., 1987) which would lead to an important fraction of the material fermented in the caecum to be lost in hard faeces, and accordingly part of the microorganisms produced. The latter could partially explain the reduction of the faecal starch digestibility observed with the increase of soluble fibre in agreement with previous studies (Gómez-Conde et al., 2009; Trocino et al., 2010; Xiccato et al., 2011), because of a higher faecal microorganisms content as also observed in rats (Rotenberg et al., 1982). It might also explain the reduction of faecal protein digestibility together with the higher proportion of protein linked to NDF in HSF diets,. 
Microbial protein accounts for $40 \%$ of the total faecal protein (Carabaño et al., 2000), and the glucose linked to starch content in microbial cells are around 2.4\% (Merry and McAllan, 1983). However, other factor may be implicated as these effects are not always detected (Trocino et al., 2011; Abad-Guamán et al., 2015). Taken together our results indicate that the reduction of mortality in rabbits fed the high SF diets might be related to a better nutrient digestibility and disposal together with an improved mucus barrier function.

In spite of the lack of n-6/n-3 fatty acid ratio effects on mortality rate or productive and ileal digestibility traits after weaning some intriguing results were observed with their interaction with the fiber. The inclusion of n-3 fatty acids significantly reduced the total digestive tract and especially the caecum in animals fed the LSF diets. Moreover, in rabbits fed the LSF diets there was a numerically lower mortality in those fed the Ln-6/n3 ratio. This was coincident with a decrease in IL-8 and IL-6 expression in the appendix of this LSF_Ln-6/n-3 fed rabbits. This is in line with established information regarding the beneficial effects of $n-3$ to decrease the pro-inflammatory IL- 8 and IL-6 in disease (Calder, 2003). On the other hand, the expression of IL-2, IL-10, INFg and TLR2 in the ileum was increased in rabbits fed the high n-3 diets irrespective of the fiber source. These effects seem to be contradictory given the anti-inflammatory role of n-3. However, no serious damage or inflammatory implications can be ruled out given the lack of effect on the pro-inflammatory IL-6, IL-8 and iNOS and the reported no effects on mortality. By contrast, it might be plausible that the higher total PUFA concentrations in the Ln-6/n-3 diets are more vulnerable to oxidation and hence can cause the increase of some inflammatory markers as observed by Awada et al. (2012) in rats.

In conclusion, the increase of the level of dietary soluble fibre improved intestinal health of growing rabbits, although it did not reduce mortality under an acceptable threshold, whereas the incorporation of n-3 PUFA had no additional benefits. 
Table 1. Sequences for primers (forward and reverse) for real-time reverse-transcription PCR amplification of target genes.

\begin{tabular}{|c|c|c|c|}
\hline Gene $^{1}$ & GenBank & Forward & Reverse \\
\hline HPRT & M31642 & 5'-TGATAGATCCATTCCTATGACTGTAGA-3' & 5'-GGGTCCTTTTCACCAGCAG-3' \\
\hline $\mathrm{GADPH}^{3}$ & AB231852 & 5'-GGG CGT GAA CCA CGA GAA-3' & 5'-GCC GAA GTG GTC GTG GAT-3' \\
\hline IL-10 ${ }^{2}$ & D84217 & 5'-GAGAACCACAGTCCAGCCAT-3' & 5'-CATGGCTTTGTAGACGCCTT-3' \\
\hline IL-6 & DQ680161 & 5'-GAGCATCCTGGAGACCATCAA-3' & 5'-CCAGTGCCTCCTTTCTGTTCA-3' \\
\hline IL-8 & Ensembl $^{4}$ & 5'-GCAACCTTCCTGCTCTCTCTGA-3' & 5'-CACTGGCATCGAAGCTCTGTAC-3' \\
\hline IL-2 & Ensembl $^{5}$ & 5'-TGAAACATCTTCAGTGTCTAGAAG-3' & 5'-CCATTTGTTCAGAAATTCTACAATG-3' \\
\hline iNOS & NM_000625 & 5'-GCCATCGAGTTTGTCAACCA-3' & 5'-TCCTTTGTGACCGCTTCCA-3' \\
\hline IFN- $\gamma$ & NM_001081991.1 & 5'-TTCTTCAGCCTCACTCTCTCC-3' & 5'-TGTTGTCACTCTCCTCTTTCC-3' \\
\hline TLR- $2^{6}$ & NM_001082781 & 5'-TGTCTCTCACCGAACCG-3' & 5'-CAACTCCATTAAGGGTGC-3' \\
\hline TLR- $4^{6}$ & NM_001082732 & 5'-GAGCACCTGGACCTTTCAAATAAC-3' & 5'-GAACTTCTAAACCACTCAGCCCTTG-3' \\
\hline MUC- $1^{7}$ & XM_002715331.2 & 5'-CGTGTGTCAGTGCCGTCGCA-3' & 5'-TACCCCCGTTGCCCGCAGAT-3' \\
\hline MUC- $-13^{7}$ & XM_002716418.1 & 5'-GCACCTGTCTGCCGGGCTAC-3 & $5^{\prime}$-CAGCAGATCACCGCGACCAC-3' \\
\hline
\end{tabular}

${ }^{1}$ Target genes: glyceraldehyde-3 phosphate = GAPDH; tumor necrosis factor-alpha = TNF- $\alpha$; IL-2; IL-6; IL-8; IL-10; inducible nitric oxide synthase $=$ iNOS; interferon gamma $=$ IFN- $\gamma .{ }^{2}$ Godornes et al. 2007. ${ }^{3}$ Chamorro et al. 2010. ${ }^{4}$ Rabbit Ensembl ENSOCUG00000011835. ${ }^{5}$ Rabbit Ensembl ENSOCUG00000010100. ${ }^{6}$ Chen et al., 2014. ${ }^{7}$ Bäuerl et al. 2014. 
Table 2. Effect of level of soluble fibre and type of fatty acids on mortality of rabbits in three different fattening periods.

\begin{tabular}{|c|c|c|c|c|c|c|c|}
\hline & \multicolumn{4}{|c|}{ Diets $^{1}$} & \multicolumn{3}{|c|}{ P-value } \\
\hline & LSF_Hn-6/n-3 & LSF_Ln-6/n-3 & HSF_Hn-6/n-3 & HSF_Ln-6/n-3 & SF & $n-6 / n-3$ & $\mathrm{SF} \times \mathrm{n}-6 / \mathrm{n}-3$ \\
\hline Trial $4^{2}$ & 17.9 & 10.7 & 2.00 & 1.80 & $<0.001$ & 0.64 & 0.75 \\
\hline Trial $1^{3}$ & 29.8 & 26.8 & 20.3 & 21.3 & 0.049 & 0.83 & 0.61 \\
\hline Trial 24 & 38.3 & 35.8 & 34.7 & 30.0 & 0.17 & 0.30 & 0.73 \\
\hline
\end{tabular}

${ }^{1}$ LSF_Hn-6/n-3 = Low soluble fibre_High n-6/n-3 fatty acid ratio; LSF_Ln-6/n-3 = Low soluble fibre_Low n-6/n-3 fatty acid ratio; HSF_Hn-6/n-3 = High soluble fibre_High n-6/n-3 fatty acid ratio; HSF_Ln-6/n-3 = High soluble fibre_Low n-6/n-3 fatty acid ratio. ${ }^{2}$ Trial 4 . N (cages/diet; $3-4$ rabbits/cage): 16 cages/diet (56 rabbits/diet). ${ }^{3}$ Trial 1. N (cages/ diet; 2-3 rabbits/cage): LSF_Hn-6/n-3 = 47 (124 rabbits); LSF_Ln-6/n-3 = 52 (153 rabbits); HSF_Hn-6/n-3 = 44 (118 rabbits); HSF_Ln-6/n-3 = 42 (122 rabbits). ${ }^{4}$ Trial 2. N (cages/ diet; 2-3 rabbits/cage): LSF_Hn-6/n-3 = 41 (115 rabbits); LSF_Ln-6/n-3 = 71 (218 rabbits); HSF_Hn-6/n-3 = 92 (277 rabbits); HSF_Ln-6/n-3 = 82 (243 rabbits). 
Table 3. Effect of level of soluble fibre and type of fatty acids on growth performance (Trial 4).

\begin{tabular}{|c|c|c|c|c|c|c|c|c|c|c|}
\hline \multirow[b]{3}{*}{$\mathrm{N}^{2}$} & \multicolumn{4}{|c|}{ Diets $^{1}$} & \multicolumn{2}{|c|}{ SEM } & \multicolumn{4}{|c|}{ P-value } \\
\hline & LSF_Hn-6/n-3 & LSF_Ln-6/n-3 & HSF_Hn-6/n-3 & HSF_Ln-6/n-3 & $\begin{array}{l}\text { SF and } \\
n-6 / n-3\end{array}$ & $\begin{array}{c}\mathrm{SFx} \\
\mathrm{n}-6 / \mathrm{n}-3\end{array}$ & $\mathrm{Cov}^{2}$ & SF & $n-6 / n-3$ & SF $\times n-6 / n-3$ \\
\hline & 9 & 12 & 12 & 9 & & & & & & \\
\hline Body weight $26 \mathrm{~d}$ of age, $g$ & $390^{\mathrm{a}}$ & $547^{\mathrm{c}}$ & $502^{\mathrm{bc}}$ & $494^{\mathrm{b}}$ & 18.8 & 26.4 & - & 0.27 & 0.010 & 0.005 \\
\hline Body weight $39 \mathrm{~d}$ of age, $\mathrm{g}$ & 1108 & 1089 & 1106 & 1107 & 24.1 & 36.1 & $<0.001$ & 0.82 & 0.82 & 0.80 \\
\hline Weight gain, g/d & 44.0 & 42.6 & 43.8 & 43.9 & 1.72 & 2.58 & 0.066 & 0.82 & 0.82 & 0.80 \\
\hline Feed intake, $g / d$ & 56.8 & 65.3 & 54.8 & 55.7 & 1.49 & 2.23 & 0.86 & 0.012 & 0.059 & 0.14 \\
\hline Feed efficiency, g/g & 0.765 & 0.656 & 0.805 & 0.879 & 0.03 & 0.04 & 0.12 & 0.059 & 0.21 & 0.37 \\
\hline
\end{tabular}

${ }^{1}$ LSF_Hn-6/n-3 = Low soluble fibre_High n-6/n-3 fatty acid ratio; LSF_Ln-6/n-3 = Low soluble fibre_Low n-6/n-3 fatty acid ratio; HSF_Hn-6/n-3 = High soluble fibre_High n-6/n-3 fatty acid ratio; HSF_Ln-6/n-3 = High soluble fibre_Low $n-6 / n-3$ fatty acid ratio. ${ }^{2}$ Body weight at $26 \mathrm{~d} .{ }^{2} \mathrm{~N}=$ number of pools/treatment. ${ }^{\mathrm{a}-\mathrm{b}}$ Growth performance with different subscript indicated that $\mathrm{P}<0.05$. 
Table 4. Effect of level of soluble fibre and type of fatty acids on ileal apparent digestibility of rabbits at $39 \mathrm{~d}$ of age (Trial 4).

\begin{tabular}{|c|c|c|c|c|c|c|c|c|c|}
\hline \multirow[b]{3}{*}{$\mathrm{N}^{2}$} & \multicolumn{4}{|c|}{ Diets $^{1}$} & \multicolumn{2}{|c|}{ SEM } & \multicolumn{3}{|c|}{ P-value } \\
\hline & \multirow{2}{*}{$\frac{\text { LSF_Hn-6/n-3 }}{9}$} & \multirow{2}{*}{$\frac{\mathrm{LSF}_{-} \mathrm{Ln}-6 / \mathrm{n}-3}{12}$} & \multirow{2}{*}{$\frac{\text { HSF_Hn-6/n-3 }}{12}$} & \multirow{2}{*}{$\frac{\text { HSF_Ln-6/n-3 }}{9}$} & \multirow[t]{2}{*}{$\begin{array}{l}\text { SF and } \\
n-6 / n-3\end{array}$} & \multirow[t]{2}{*}{$\begin{array}{c}\text { SFx } \\
n-6 / n-3\end{array}$} & \multirow[t]{2}{*}{$\mathrm{SF}$} & \multirow[t]{2}{*}{$n-6 / n-3$} & \multirow[t]{2}{*}{$\mathrm{SF} \times \mathrm{n}-6 / \mathrm{n}-3$} \\
\hline & & & & & & & & & \\
\hline \multicolumn{10}{|c|}{ Apparent ileal digestibility, \%DM } \\
\hline Dry matter & 49.6 & 44.5 & 49.5 & 51.4 & 3.74 & 6.21 & 0.52 & 0.76 & 0.52 \\
\hline Starch & 97.8 & 97.5 & 98.3 & 98.7 & 0.30 & 0.43 & 0.064 & 0.81 & 0.44 \\
\hline $\mathrm{TDF}$ & 13.3 & 12.3 & 25.0 & 25.5 & 3.81 & 5.38 & 0.029 & 0.96 & 0.88 \\
\hline \multicolumn{10}{|l|}{ Mucin production } \\
\hline $\mathrm{g} / \mathrm{kg}$ ileal DM & 66.2 & 64.6 & 76.4 & 76.0 & - & - & - & - & - \\
\hline $\mathrm{g} \mathrm{DM} / \mathrm{d}$ & 1.70 & 1.82 & 1.97 & 1.62 & 0.10 & 0.15 & 0.79 & 0.44 & 0.12 \\
\hline $\mathrm{g} / \mathrm{kg} \mathrm{DM}$ intake & 33.3 & 31.4 & 38.5 & 37.0 & 1.81 & 2.56 & 0.043 & 0.49 & 0.94 \\
\hline \multicolumn{10}{|c|}{ Ileal flow of nutrients, $\mathrm{g} / \mathrm{d}$} \\
\hline Dry matter & 25.6 & 28.2 & 25.8 & 21.3 & 1.49 & 2.10 & 0.12 & 0.64 & 0.10 \\
\hline Starch & 0.40 & 0.33 & 0.19 & 0.12 & 0.07 & 0.10 & 0.058 & 0.51 & 0.99 \\
\hline $\mathrm{TDF}$ & 17.3 & 18.6 & 18.2 & 15.8 & 1.03 & 1.46 & 0.53 & 0.72 & 0.21 \\
\hline
\end{tabular}

${ }^{1}$ LSF_Hn-6/n-3 = Low soluble fibre_High n-6/n-3 fatty acid ratio; LSF_Ln-6/n-3 = Low soluble fibre_Low n-6/n-3 fatty acid ratio; HSF_Hn-6/n-3 = High soluble

fibre_High n-6/n-3 fatty acid ratio; HSF_Ln-6/n-3 = High soluble fibre_Low n-6/n-3 fatty acid ratio. ${ }^{2} \mathrm{~N}=$ number of pools/treatment. 
Table 5. Effect of level of soluble fibre and type of fatty acids on fecal apparent digestibility of rabbits from 39 to $42 \mathrm{~d}$ of age (Trial 3 ).

\begin{tabular}{|c|c|c|c|c|c|c|c|c|c|}
\hline \multirow[b]{3}{*}{$\mathrm{N}$} & \multicolumn{4}{|c|}{ Diets $^{1}$} & \multicolumn{2}{|c|}{ SEM } & \multicolumn{3}{|c|}{ P-value } \\
\hline & \multirow{2}{*}{$\frac{\text { LSF_Hn-6/n-3 }}{12}$} & \multirow{2}{*}{$\frac{\mathrm{LSF}_{-} \mathrm{Ln}-6 / \mathrm{n}-3}{13}$} & \multirow{2}{*}{$\frac{\text { HSF_Hn-6/n-3 }}{14}$} & \multirow{2}{*}{$\frac{\text { HSF_Ln-6/n-3 }}{12}$} & \multirow{2}{*}{$\begin{array}{l}\text { SF and } \\
n-6 / n-3\end{array}$} & \multirow{2}{*}{$\begin{array}{c}\text { SFx } \\
n-6 / n-3\end{array}$} & \multirow[t]{2}{*}{ SF } & \multirow[t]{2}{*}{$n-6 / n-3$} & \multirow{2}{*}{$\begin{array}{c}\text { SFx } \\
n-6 / n-3\end{array}$} \\
\hline & & & & & & & & & \\
\hline Dry matter intake $39-42 \mathrm{~d}, \mathrm{~g} / \mathrm{d}$ & 112 & 99.1 & 98.6 & 98.1 & 2.94 & 4.16 & 0.099 & 0.12 & 0.15 \\
\hline \multicolumn{10}{|l|}{ Apparent faecal digestibility, \%DM } \\
\hline Dry matter & 64.1 & 63.7 & 64.6 & 65.1 & 0.57 & 0.80 & 0.27 & 0.96 & 0.57 \\
\hline Crude protein & 77.6 & 77.2 & 76.2 & 75.2 & 0.56 & 0.79 & 0.040 & 0.39 & 0.75 \\
\hline Ether extract & 80.3 & 81.6 & 77.7 & 81.5 & 0.86 & 1.22 & 0.26 & 0.043 & 0.32 \\
\hline Starch & 99.1 & 99.1 & 98.6 & 98.7 & 0.09 & 0.12 & $<0.001$ & 0.77 & 0.96 \\
\hline TDF & $32.5^{b}$ & $28.3^{\mathrm{a}}$ & $41.6^{c}$ & $43.5^{c}$ & 0.94 & 1.33 & $<0.001$ & 0.39 & 0.028 \\
\hline${ }_{\mathrm{a}} \mathrm{NDF}_{\text {om-cp }}$ & 26.1 & 23.6 & 30.6 & 31.1 & 1.19 & 1.43 & $<0.001$ & 0.56 & 0.37 \\
\hline Soluble fibre & $56.1^{b}$ & $48.7^{\mathrm{a}}$ & $68.1^{\mathrm{c}}$ & $72.8^{c}$ & 1.52 & 2.15 & $<0.001$ & 0.54 & 0.008 \\
\hline \multicolumn{10}{|l|}{ Mucin production } \\
\hline g/kg Faeces DM & 6.70 & 6.20 & 7.32 & 6.84 & 0.54 & 0.76 & 0.41 & 0.52 & 0.99 \\
\hline $\mathrm{g} \mathrm{DM} / \mathrm{d}$ & 0.263 & 0.224 & 0.259 & 0.235 & 0.02 & 0.03 & 0.91 & 0.30 & 0.81 \\
\hline $\mathrm{g} / \mathrm{kg}$ DM Intake & 2.37 & 2.24 & 2.59 & 2.38 & 0.18 & 0.26 & 0.50 & 0.52 & 0.88 \\
\hline Mucin Protein, $\%$ & 9.04 & 8.96 & 10.3 & 8.02 & - & - & - & - & - \\
\hline
\end{tabular}

${ }^{1}$ LSF_Hn-6/n-3 = Low soluble fibre_High n-6/n-3 fatty acid ratio; LSF_Ln-6/n-3 = Low soluble fibre_Low n-6/n-3 fatty acid ratio; HSF_Hn-6/n-3 = High soluble fibre_High n-6/n-3 fatty acid ratio; HSF_Ln-6/n-3 = High soluble fibre_Low n-6/n-3 fatty acid ratio. ${ }^{\mathrm{a}-\mathrm{c}}$ Faecal digestible mean values in the same column with a different superscript differ $\mathrm{P}<0.05$. 
Table 6. Effect of level of soluble fibre and type of fatty acids on visceral organ weight at $39 \mathrm{~d}$ of age (Trial 4).

\begin{tabular}{|c|c|c|c|c|c|c|c|c|c|}
\hline \multirow[b]{3}{*}{$\mathrm{N}$} & \multicolumn{4}{|c|}{ Diets $^{1}$} & \multicolumn{2}{|c|}{ SEM } & \multicolumn{3}{|c|}{ P-value } \\
\hline & \multirow{2}{*}{$\frac{\text { LSF_Hn-6/n-3 }}{32}$} & \multirow{2}{*}{$\frac{\text { LSF_Ln-6/n-3 }}{35}$} & \multirow{2}{*}{$\frac{\text { HSF_Hn-6/n-3 }}{38}$} & \multirow{2}{*}{$\frac{\text { HSF_Ln-6/n-3 }}{39}$} & \multirow{2}{*}{$\begin{array}{l}\text { SF and } \\
n-6 / n-3\end{array}$} & \multirow{2}{*}{$\begin{array}{c}\text { SFx } \\
n-6 / n-3\end{array}$} & \multirow[t]{2}{*}{ SF } & \multirow[t]{2}{*}{$n-6 / n-3$} & \multirow[t]{2}{*}{$\mathrm{SF} \times \mathrm{n}-6 / \mathrm{n}-3$} \\
\hline & & & & & & & & & \\
\hline \multicolumn{10}{|c|}{ Relative weight of full organs (\%BW) } \\
\hline Total digestive tract & $29.5^{\mathrm{b}}$ & $26.6^{\mathrm{a}}$ & $28.6^{\mathrm{b}}$ & $29.2^{\mathrm{b}}$ & 0.37 & 0.52 & 0.12 & 0.030 & 0.001 \\
\hline Stomach & 8.23 & 7.41 & 7.99 & 8.02 & 0.16 & 0.23 & 0.42 & 0.080 & 0.063 \\
\hline Caecum & 10.7 & 9.48 & 10.1 & 10.1 & 0.23 & 0.32 & 0.94 & 0.048 & 0.054 \\
\hline Liver & 6.01 & 5.98 & 5.70 & 5.61 & 0.11 & 0.16 & 0.030 & 0.72 & 0.86 \\
\hline Caecal pH & $5.92^{\mathrm{b}}$ & $5.49^{\mathrm{a}}$ & $5.55^{\mathrm{a}}$ & $5.57^{\mathrm{a}}$ & 0.04 & 0.06 & 0.022 & 0.001 & $<0.001$ \\
\hline
\end{tabular}


Table 7. Effect of level of soluble fibre and type of fatty acids on soft faeces production at $42 \mathrm{~d}$ (Trial 3).

\begin{tabular}{|c|c|c|c|c|c|c|c|c|c|}
\hline \multirow[b]{3}{*}{$\mathrm{N}$} & \multicolumn{4}{|c|}{ Diets $^{1}$} & \multicolumn{2}{|c|}{ SEM } & \multicolumn{3}{|c|}{ P-value } \\
\hline & LSF_Hn-6/n-3 & LSF_Ln-6/n-3 & HSF_Hn-6/n-3 & HSF_Ln-6/n-3 & $\begin{array}{l}\text { SF and } \\
n-6 / n-3\end{array}$ & $\begin{array}{c}\mathrm{SFx} \\
\mathrm{n}-6 / \mathrm{n}-3\end{array}$ & SF & $n-6 / n-3$ & SF $\times n-6 / n-3$ \\
\hline & 12 & 12 & 11 & 10 & & & & & \\
\hline Soft faeces, g/day of DM & 31.4 & 30.6 & 28.8 & 29.7 & 0.58 & 0.82 & 0.037 & 0.98 & 0.31 \\
\hline Crude protein, $\%$ of DM & 27.9 & 27.5 & 28.6 & 30.8 & 0.55 & 0.78 & 0.015 & 0.24 & 0.11 \\
\hline Recycled protein, g/day DM & 8.76 & 8.42 & 8.32 & 9.15 & 0.24 & 0.34 & 0.68 & 0.47 & 0.092 \\
\hline
\end{tabular}

${ }^{1}$ LSF_Hn-6/n-3 = Low soluble fibre_High n-6/n-3 fatty acid ratio; LSF_Ln-6/n-3 = Low soluble fibre_Low n-6/n-3 fatty acid ratio; HSF_Hn-6/n-3 = High soluble fibre_High $\mathrm{n}-6 / \mathrm{n}-3$ fatty acid ratio; HSF_Ln-6/n-3 = High soluble fibre_Low n-6/n-3 fatty acid ratio. 
Table 8. Effect of level of soluble fibre and type of fatty acids on gene expression expressed as $\Delta \mathrm{Ct}$ (diane gene-bestkeeper) of immune cytokines in appendix and ileum (Trial 4).

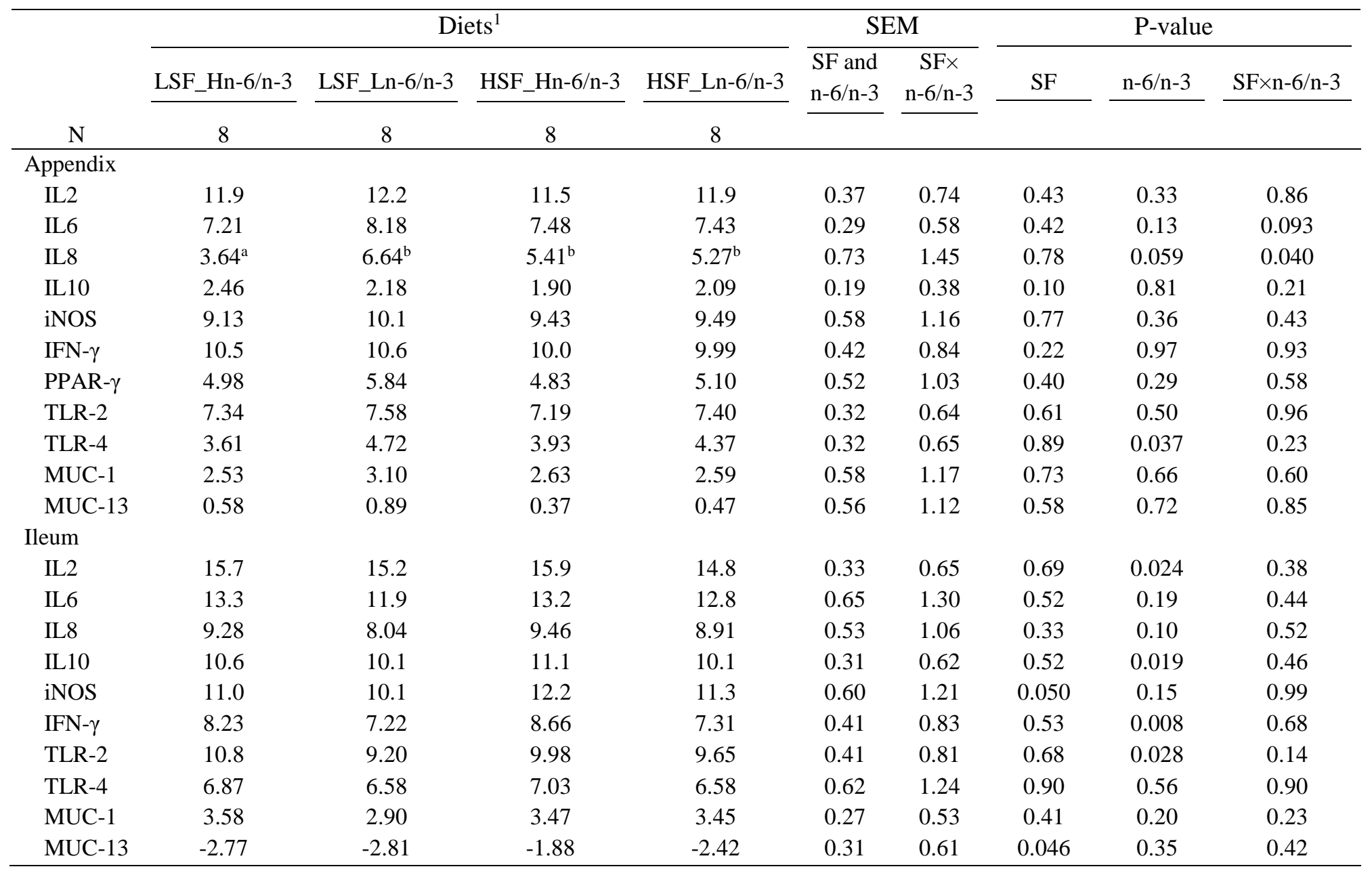

${ }^{1}$ LSF_Hn-6/n-3 = Low soluble fibre_High n-6/n-3 fatty acid ratio; LSF_Ln-6/n-3 = Low soluble fibre_Low n-6/n-3 fatty acid ratio; HSF_Hn-6/n-3 = High soluble fibre_High n-6/n-3 fatty acid ratio; HSF_Ln-6/n-3 = High soluble fibre_Low n-6/n-3 fatty acid ratio. ${ }^{\text {a-c }}$ Gene expression with different subscript in the same row indicated that $\mathrm{P}<0.05$. 
Chapter 5

General discussion 



\section{GENERAL DISCUSSION}

Traditionally, the use of additives/nutrition strategies to promote the intestinal health in non-ruminants have been focused on the post-weaning period that is the most critical one (Carabaño et al., 2008). However, there are some evidences of the relevance of the pre-natal and lactation periods on the future gut function and metabolism of young mammals (Gabler et al., 2007; Morel et al., 2015). The uterine nutrient flow during pregnancy, the potential transference of intestinal microbiota from the mother to the litter, including their translocation in the digestive tract, or the milk composition are important factors that seems to condition the short and long term performance of the young animals (Gavin and Ostovar, 1997; Welsh and May, 1979; Hikkila and Saris, 2003; Martín et al., 2004; Donet-Hughes et al., 2010). Several interesting effects related to the pre-natal and lactation period have been reported in this $\mathrm{PhD}$ Thesis (trend to modify litter size and average neonatal weight of kits by single supplementation of Arg and Gln, reduction of the translocation of total number of both aerobic and facultative anaerobic bacteria to the MLN at $6 \mathrm{~d}$ of age, maintained intestinal villous height and upregulation of IL-2 and IL10 and downregulation of IL-6 expression at weaning by Gln supplementation, or the modification of milk production and profile and the bacterial profile of hard faeces and milk of rabbit does or mesentheric lymph nodes of young kits by the combination of soluble fibre and n-6/n-3 ratio. Chapters 3.1, 3.3, 4.1 and Delgado et al., 2015).

In this context, it would have been expected some influence of the pre-weaning changes in the health status of growing rabbits after weaning. However, when rabbits were offered a common diet after weaning no positive influence of the pre-weaning treatments on rabbit health were observed when an ERE outbreak occurred. In contrast, some characteristic of the diet provided after weaning was successful to limit the incidence of the disease (as the level of soluble fibre) and others (glutamine and n-6/n-3 ratio) influenced the immune response (Chapters 3.3 and 4.3). It questions the relevance of the pre-weaning effects in an ERE context, although it is well documented the link between the maternal effects and the growth traits and mortality of the litter after weaning (they accounts for $40 \%$ of the total variability of feed efficiency, while $22 \%$ of females accounted for $50 \%$ of the mortality during fattening. García et al., 2001; Quevedo et al., 2003). Nevertheless, the practical implications of most of the pre-weaning effects are not still clear. 
It is well accepted that the health risk increases after weaning because the young rabbit is still immature from a digestive (including the intestinal microbiota) and immune point of view (Chapter 2), and the post-weaning period coincides with a time of strong changes where the protective role of milk is lost. However, it is not known many aspects of the adaptive mechanisms working in the young rabbit at this age. The results of this $\mathrm{PhD}$ Thesis provides additional information about the maturation process of young rabbits in which they probably have specific nutrient requirements. The use of functional amino acids and the reduction of the n-6/n-3 fatty acid ratio exerted apparent positive effects on the immune system, although they were not able to reduce the mortality rate. In the case of ERE, the studies are developed with a deficient knowledge of the pathological process and in conditions of natural infection that complicates the interpretation of the results obtained. It remarks the importance to know how the disease is developed, identify the metabolic actions of the studied substances that may be behind their positive effects on the intestinal health, and adjust the proper dose and time of application. This is especially relevant for the interpretation of immune recordings. There is a general agreement in the immune response obtained in the different trials. The use of 'apparent healthy' rabbits for sampling would account for it, and it might be also behind the lack of relationship between the mortality rate and immune response in some trials done in this $\mathrm{PhD}$. Thesis.

In this $\mathrm{PhD}$ Thesis, new criteria as the body condition (chemical and energy composition) were recorded to evaluate the influence of dietary treatments on the rabbit doe. The higher risk of culling of rabbit does occurs in the first three cycles (inseminations) mainly due to low productivity (fertility) and poor body condition (Rosell and de la Fuente, 2009). The second insemination is more difficult than the other ones probably due to the negative energy balance observed at the end of the first pregnancy period and/or at the beginning of the first lactation (Fortun-Lamothe et al., 2006). The fertility of the second insemination seems to depend on the maturity of the rabbit doe at first insemination which would be determined by its body protein and fat content at that moment (Taghouti et al., 2011) and/or by a better management of body reserves around the first parturition (Savietto et al., 2016). In this circumstances the rabbit does selected for reproductive longevity obtained better results compared with the hyper-prolific line, probably due to its major plasticity in the management of body reserves (Theilgaard et 
al., 2009). Additionally, the fattest rabbit does have a higher risk of culling (Theilgaard et al., 2006).

However, the dietary treatments had a minor or almost none influence on the body condition of rabbit does (Theilgaard et al., 2006; Romero et al., 2011; Chapters 3.1 and 4.1). It might be accounted for the use of balanced diets that met the current nutrient requirements (De Blas and Mateos et al., 2010). In contrast, there was a strong effect of time (moment in the reproduction cycle) on the body condition of rabbit does (Chapters 3.1 and 4.1) having the latter an apparent influence on the reproductive success. For this reason, data recorded in these two experiments (a total of 172 rabbit does along the first 5 inseminations) were combined to study the relationship between body condition and/or protein and fat mobilization and reproductive success (no. pregnancies/total no. inseminations). For this purpose, rabbit does were classified a posteriori in two groups: Elite $(n=42$. Pregnant in all inseminations: reproductive success 100\%) and Standard rabbit does $(n=172$. At least, once lactation period completed and a worse reproductive success 66\% than the Elite group, $\mathrm{P}<0.001$ ) (Figure 1 and Table 1). In the first insemination, Elite rabbit does were lighter (3930 vs. $4087 \mathrm{~g} ; \mathrm{P}=0.025$ ) and had lower body fat proportion (15.7 vs. $17.2 \%$; $=0.042)$ than the Standard group, but they had a similar body protein content (17.8 vs. $17.9 \%)$ that might be an optimal maturity degree according to Taghouti et al. (2011). Besides, the Elite group showed a higher body protein proportion at first parturition (17.9 vs. $17.7 \%$; $\mathrm{P}=0.012)$ and first weaning (18.1 vs. $17.9 \% ; \mathrm{P}=0.027)$. Fat and protein mobilization/deposition between the first insemination and first parturition or between the first parturition and the second insemination did not differ between the two groups. A great fat mobilization was observed in the first period (1st insemination-1st parturition), probably at the end, and a partial recover of reserves in the second period (1st parturition-2nd insemination) which is in agreement with that reported by Savietto et al. (2016). However, the Elite group mobilized the double quantity of fat between the second insemination and the first weaning (27.9 vs. $14.1 \%$; $\mathrm{P}=0.004$. Figure 1). It allowed predicting the reproductive success from the fat mobilization in this period using a logistic regression (Figure 2). This fat mobilization was independent from the type of diet provided and the digestible energy and nitrogen intake (Figure 3) or the milk production (similar in both groups, although Elite group tended to wean a greater number of kits). It might have and genetic origin (Pascual et al., 2013), and rabbit does with lower risk of culling would be those with a better management of body resources. It 
would be interesting an early identification of these animals as well as the environmental factors that may be influencing their productivity. 
Tabla 1. Composición corporal, energía y peso vivo de las conejas en la inseminación artificial 1.

\begin{tabular}{|c|c|c|c|c|c|c|c|c|c|}
\hline & \multicolumn{3}{|c|}{ Body weight $^{*}$} & \multicolumn{3}{|c|}{ Moisture $^{*}$} & \multicolumn{3}{|c|}{ Protein } \\
\hline & All & Elite & Standard & All & Elite & Standard & All & Elite & Standard \\
\hline Average $^{\dagger}$ & $\overline{4048}$ & $\overline{3930}$ & 4087 & $\overline{58,3}$ & $\overline{59,4}$ & 58,0 & $\overline{17,83}$ & $\overline{17,91}$ & 17,81 \\
\hline $\mathrm{SE}$ & 317 & 282 & 320 & 2,57 & 2,95 & 2,34 & 0,47 & 0,50 & 0,45 \\
\hline Min & 3364 & 3364 & 3463 & 51,0 & 54,0 & 51,0 & 16,00 & 16,40 & 16,00 \\
\hline Max & 5104 & 4655 & 5104 & 66,4 & 66,4 & 65,0 & 18,60 & 18,60 & 18,50 \\
\hline \multirow[t]{3}{*}{ P-value } & \multicolumn{3}{|c|}{0,025} & \multicolumn{3}{|c|}{0,041} & \multicolumn{3}{|c|}{0,34} \\
\hline & \multicolumn{3}{|c|}{ Fat $^{*}$} & \multicolumn{3}{|c|}{ Ash } & \multicolumn{3}{|c|}{ Energy* $^{*}$} \\
\hline & All & Elite & Standard & All & Elite & Standard & All & Elite & Standard \\
\hline Average $^{\dagger}$ & $\overline{16.8}$ & 15.7 & 17.2 & $\overline{3.03}$ & $\overline{3.07}$ & 3.02 & $\overline{1193}$ & $\overline{1147}$ & 1208 \\
\hline $\mathrm{SE}$ & 2.71 & 3.01 & 2.51 & 0.13 & 0.13 & 0.13 & 110 & 126 & 100 \\
\hline Min & 8.70 & 8.70 & 10.1 & 2.60 & 2.80 & 2.60 & 848 & 848 & 907 \\
\hline Max & 24.9 & 21.7 & 24.9 & 3.30 & 3.30 & 3.20 & 1507 & 1377 & 1507 \\
\hline P-value & & \multicolumn{2}{|c|}{0.042} & \multicolumn{3}{|c|}{0.095} & & \multicolumn{2}{|c|}{0.041} \\
\hline
\end{tabular}

${ }^{\dagger} \mathrm{N}:$ All $=172$; Elite $=42 ;$ Standard $=130$. Variables marked with $*$ indicated that Elite rabbit does are different from Standard $(\mathrm{P}<0.05)$. Units: Body weight: $\mathrm{g}$, protein, fat and ash: \% of body weight; Energy $\mathrm{kJ} / 100 \mathrm{~g}$ of body weight. 


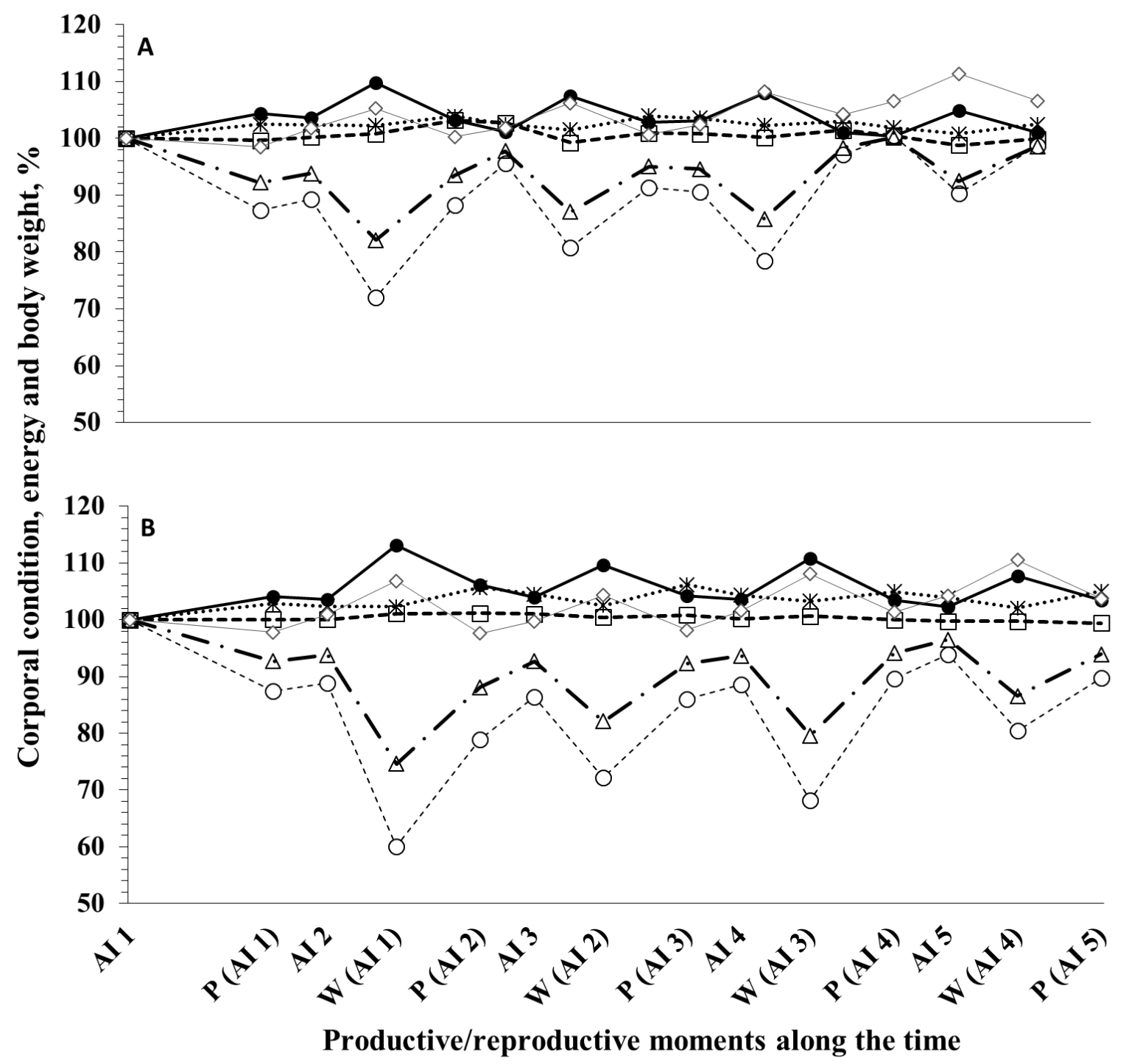

Figure 1. Evolution of body composition, energy and weight (Moisture $\bullet$, protein $\square$, fat $\circ$, ash *, energy $\Delta$, and body weight $\diamond$ ) over time (artificial insemination -AI-, parturition $-\mathrm{P}$ - and weaning $-\mathrm{W}-)$ of all rabbit does considered for the two experiments $(\mathrm{n}=172$. Figure $1 \mathrm{~A})$ or only those that had consecutive parturitions $(n=42$. Figure $1 \mathrm{~B})$. Values obtained at first artificial insemination (AI 1) were considered as 100 (see Table 1) and the values obtained after were expressed as percentage of the value obtained in the AI1. $\mathrm{P}_{\text {Time }}<0.001$ in both figures. AI 1, AI 2, AI 3 AI4 and AI5: $1^{\text {st }}, 2^{\text {nd, }} 3^{\text {rd }} 4^{\text {th }}$ and $5^{\text {th }}$ artificial insemination, respectively. P (IA 1), P (IA 2), P (IA 3), P (IA 4) and P (IA 5): Parturition corresponding to IA 1, AI 2, AI 3 and AI 4, respectively. W (IA 1), W (IA 2), W (IA 3) and W (IA 4): Weaning corresponding to IA 1, AI 2, AI 3 and AI 4, respectively. 


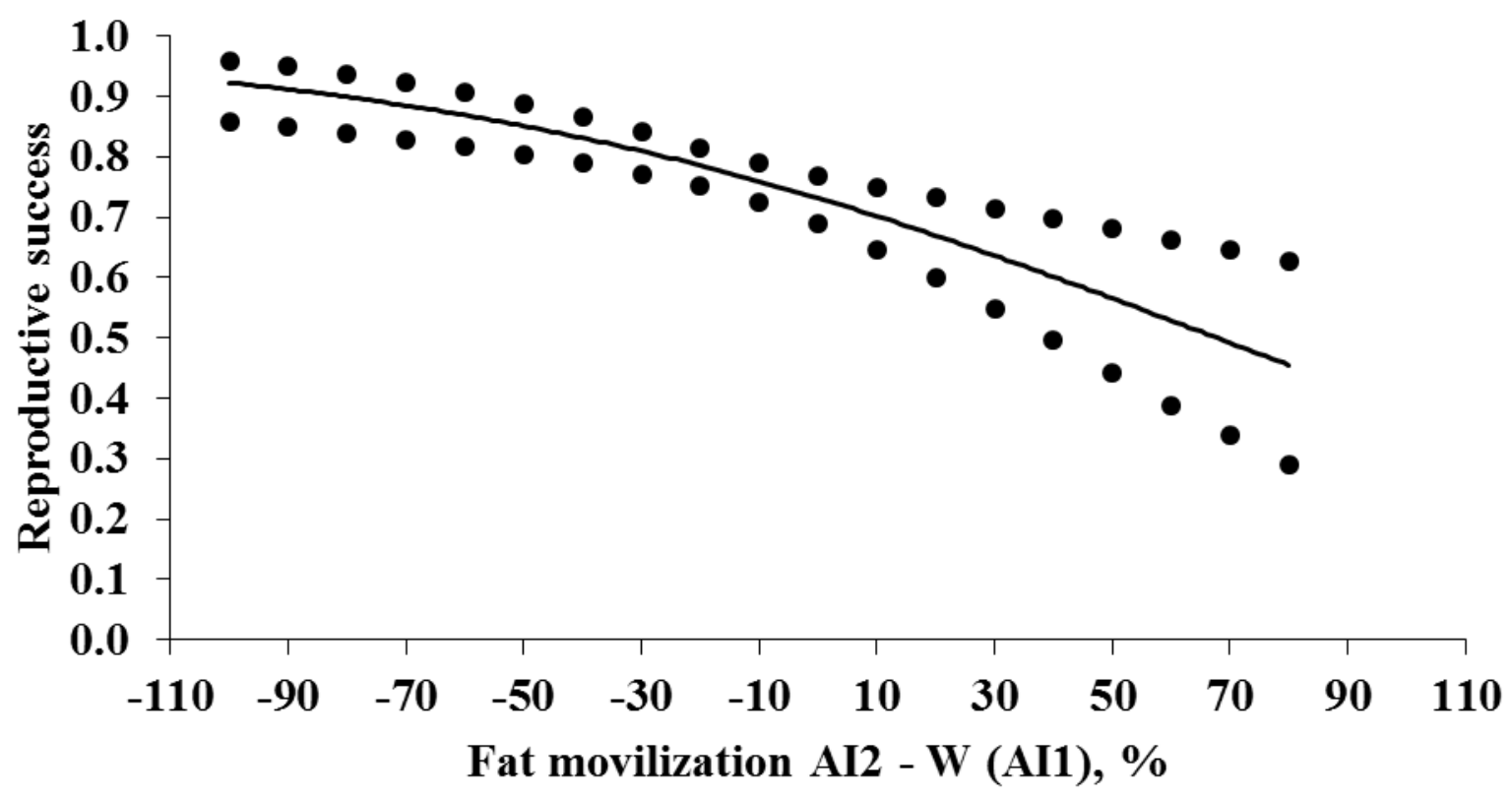

Figure 2: Reproduction success estimation in the five first AI from fat mobilization between AI2 and W (AI1) $(\mathrm{P}<0.01$; Model deviation $=0.95$. Max/Min: Reproductive success: 0.33-1, Fat mobilization AI2 - W (AI1): -96.7 to 78.2). Dotted line indicate 95\% confidence interval. 


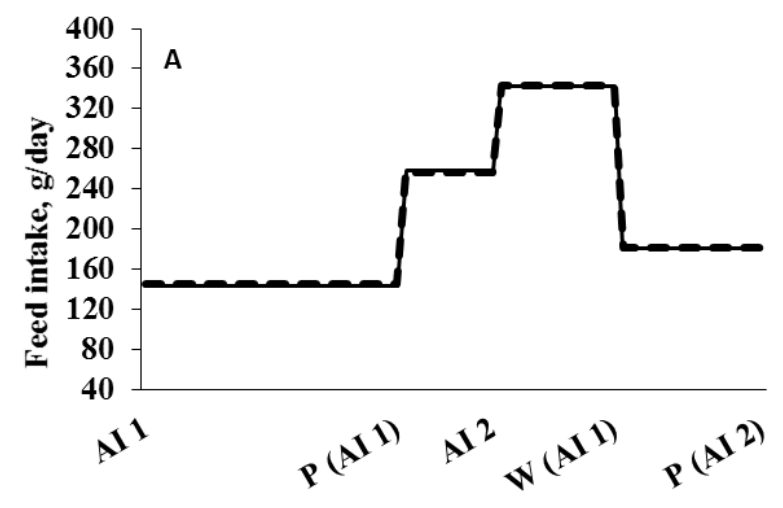

Productive/reproductive moments along time

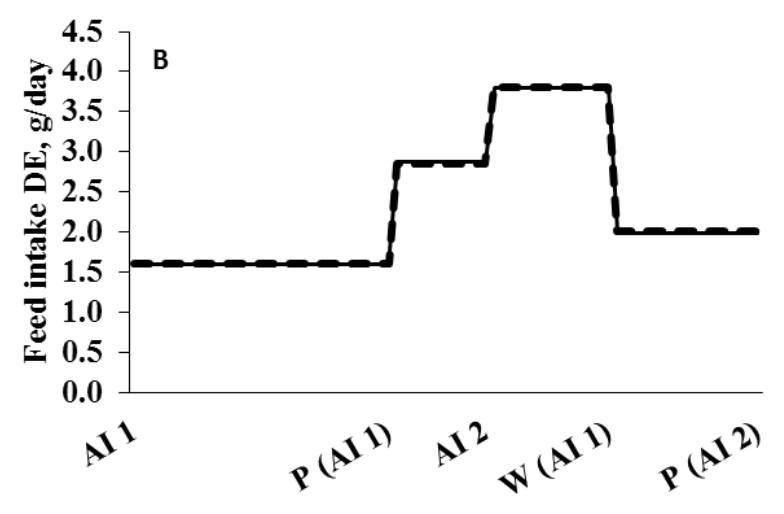

Productive/reproductive moments along time

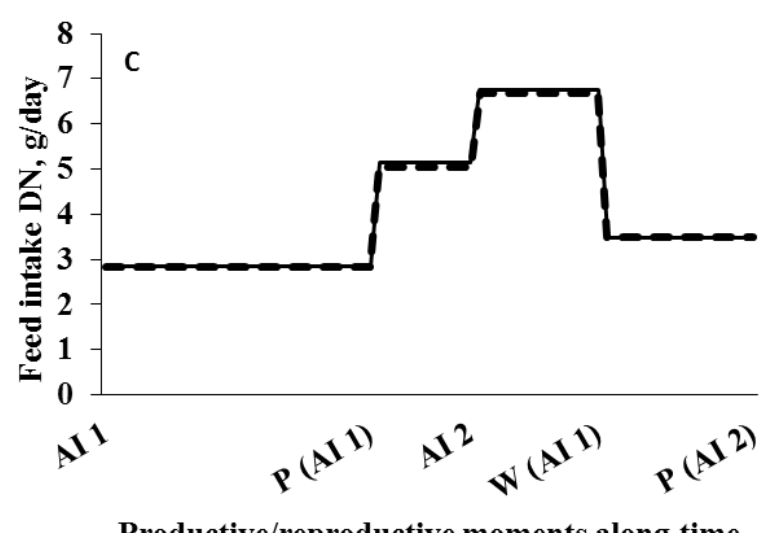

Productive/reproductive moments along time

Figure 3: Feed intake (Figure 3A), digestible energy (DE) feed intake (Figure 3B) and digestible nitrogen (DN) intake (Figure 3C) from AI1 to P (AI2) of elite - and standard ---- rabbit does. In all cases $\mathrm{P}>0.05$. 

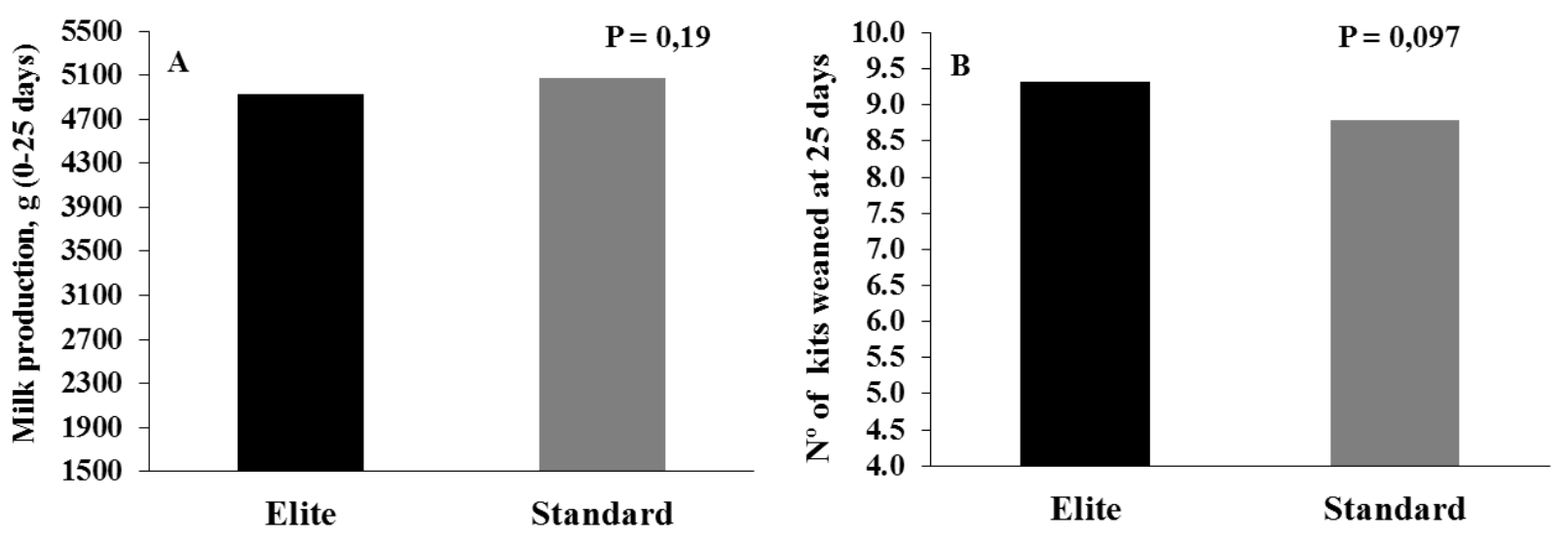

Figure 4: Milk production in $\mathrm{g}$ from 0 to $25 \mathrm{~d}$ of lactation of elite vs Standard rabbit does (Figure 4A; $\mathrm{P}=0.19$ ). Number of kits weaned at $25 \mathrm{~d}$ of age of elite vs, Standar rabbit does (Figure 4B; $\mathrm{P}=0.097$ ). 

Chapter 6

General conclusions 



\section{GENERAL CONCLUSIONS}

\section{Rabbit microbiota and immune response evolution with age.}

Just after weaning there is a specific balance between the phylum Firmicutes and Bacteroidetes both in the ileum and in the caecum.

Mucosa morphology and immune response present temporary changes and immune response that must be taken into consideration when evaluating new management/dietary strategies.

\section{Dietary supplementation with arginine and glutamine.}

\subsection{Rabbit does performance during the first three lactations.}

Dietary supplementation with $0.4 \%$ of arginine or with $0.4 \%$ of glutamine had a positive effect on the weight of litters at weaning and litter size at birth.

However, no additive effect was observed for the combined supplementation of $0.4 \%$ of arginine $+0.4 \%$ of glutamine.

Further research is required to establish the optimal dose and the best period for their supplementation.

\subsection{Growing rabbit performance and nitrogen and energy efficiency.}

Supplementation with $0.4 \%$ of glutamine to post-weaned rabbits during the first days reduced fattening mortality.

Dietary supplementation with $0.4 \%$ of arginine or with $0.4 \%$ of arginine $+0.4 \%$ of glutamine had not effect on rabbit performance

Supplementation with $0.4 \%$ of arginine reduces nitrogen and energy efficiency.

\subsection{Intestinal health in growing rabbits.}

Dietary supplementation with $0.4 \%$ of glutamine have a positive effect by maintaining intestinal villous height and inducing a cytokine profile with a more moderate and balanced Th1-Th2 response at weaning.

Dietary supplementation with $0.4 \%$ of arginine or with $0.4 \%$ of arginine $+0.4 \%$ of glutamine in this study did not report any beneficial effect on the analyzed variables.

\section{Dietary soluble fibre level and n-6/n-3 fatty acid ratio.}

\subsection{Rabbit does performance during the first four lactations.}


Dietary soluble fibre level reduced the replacement rate of rabbit does.

Both dietary soluble fibre level and n-6/n-3 fatty acid ratio modified milk composition and fatty acid profile with minor influence on litter productivity.

3.2. Growing rabbit performance and nitrogen and energy efficiency.

Dietary soluble fibre level improved the survival of fattening rabbits, but the reduction of the n-6/n-3 ratio did not influence the health of rabbits during fattening.

Both the increase of dietary soluble fibre level and the reduction of the $n-6 / n-3$ ratio improved the efficiency of the digestible energy and protein retained in the body and in the carcass.

No additive effect of both factors was found.

\subsection{Intestinal health in growing rabbits.}

In spite of the improved intestinal health of growing rabbits when dietary soluble fibre increased, it did not exert important changes in the immune response.

The ratio n-6/n-3 had no effect in spite of its positive influence on the gut-associated immune system. 
Literature cited 



\section{LITERATURE CITED}

Abad, R., 2015. Identification of the method to quantify soluble fibre and the effect of the source of fibre on the ileal and faecal digestibility of soluble and insoluble fibre in rabbits., PhD Thesis, UPM, Madrid, Spain.

Abad-Guamán, R., Carabaño, R., Gómez-Conde, M.S., García, J., 2013. Effect of type of ileal sample (individual vs. collective) and type of fibre on ileal digestibility in rabbits. In: XV Jornadas sobre Producción Animal. Zaragoza, Spain. 1, 201-203.

Abad-Guamán, R., Carabaño, R., Gómez-Conde, M. S., García, J., 2015. Effect of type of fiber, site of fermentation, and method of analysis on digestibility of soluble and insoluble fiber in rabbits. J. Anim. Sci. 93, 2860-2871.

Abbas, A.K., Lichtman, A.H., Pillai, S., 2014. Cellular and molecular immunology, eight edition. Elsevier Health Sciences.

Abecia, L., Fondevila, M., Balcells, J., Edwards, J.E., Newbold, C.J., McEwan, N.R., 2005. Molecular profiling of bacterial species in the rabbit caecum. Fems Microbiol. Lett. 244, 111-115.

Adamson, I., Fisher, H., 1973. Amino acid requirement of growing rabbit: An estimate of quantitative needs. J. Nutr. 103, 1306-1310.

Adamson, I., Fisher, H., 1976. Further studies on the arginine requirements of the rabbit. J. Nutr. 106, 717-723.

Aldridge, C., Razzak, A., Babcock, T.A., Helton, W.S., Espat, N.J., 2008. Lipopolysaccharide-stimulated RAW 264.7 macrophage inducible nitric oxide synthase and nitric oxide production is decreased by an omega-3 fatty acid lipid emulsion. J. Surg. Res. 149, 296-302.

Allen, A., Bell, A., Mantle M., Pearson, J.P., 1982. The Structure and Physiology of Gastrointestinal Mucus. Adv. Exp. Med. Biol. 144, 115-133.

Allen, P., 1999. Effects of daily oral doses of L-arginine on coccidiosis infections in chickens. Poultry Sci. 78, 1506-1509.

Álvarez, J.L., Margüenda, I., García-Rebollar, P., Carabaño, R., De Blas, J.C., Corujo, A., García-Ruiz, A.I., 2007. Effects of type and level or fibre on digestive physiology and performance in reproducing and growing rabbits. World Rabbit Sci. 15, 9-17. 
Anderson M., Fritsche K.L., 2002. (n-3) Fatty acids and infectious disease resistance. J. Nutr. 132, 3566-3576.

Antony, P.A., Paulos, C.M., Ahmadzadeh, M., Akpinarli, A., Palmer, D.C., Sato, N., Kaiser, A., Hinrichs, C.S., Klebanoff, C.A., Tagaya, Y., Restifo, N.P., 2006. Interleukin-2-dependent mechanisms of tolerance and immunity in vivo. J. Immunol. 176, 5255-5266.

Argente, M.J., Santacreu, M.A., Climent, A., Blasco, A., 2003. Relationships between uterine and fetal traits in rabbits selected on uterine capacity. J. Anim. Sci. 81, 1265-1273.

Arrieta, M.C., Bistritz, L., Meddings, J.B., 2006. Alterations in intestinal permeability. Gut. 55, 1512-1520.

Association of Official Analytical Chemists., 2000. Official Methods of Analysis $17^{\text {th }} \mathrm{ed}$. AOAC, Washington, DC.

Awada, M., Soulage, C.O., Meynier, A., Debard, C., Plaisancié, P., Benoit, B., Picard, G., Loizon, E., Chauvin, M.A., Estienne, M., Guichardant, M., Lagarde, M., Genot, C., Michalski1, M.C., 2012. Dietary oxidized n-3 PUFA induce oxidative stress and inflammation: role of intestinal absorption of 4-HHE and reactivity in intestinal cells. J. Lipid Res. 53, 2069-2080.

Bae, I., Foote, R.H., 1975. Carbohydrate and amino acid requirements and ammonia production of rabbit follicular oocytes matured in vitro. Exp. Cell Res. 91, 113118.

Bagga, D., Wang, L., Farias-Eisner, R., Glaspy, J.A., Reddy, S.T., 2003. Differential effects of prostaglandin derived from omega- 6 and omega- 3 polyunsaturated fatty acids on COX-2 expression and IL-6 secretion. Proc. Natl. Acad. Sci. USA. 100, $1751-1756$.

Baker, D.H., Boebel, K.P., 1981. Utilization of the D-isomers of arginine and histidine by chicks and rats. J. Anim. Sci. 53, 125-129.

Bakewell, L., Burdge, G.C., Calder, P.C., 2006. Polyunsaturated fatty acid concentrations in young men and women consuming their habitual diets. Br. J. Nutr. 96, 93-99.

Bäuerl, B., Collado, M.C., Zúñiga, M., Blas, E., Pérez Martínez, G., 2014. Changes in cecal microbiota and mucosal gene expression revealed new aspects of epizootic rabbit enteropathy. Plos One 9. e105707. 
Baylos, M., Menoyo, D., Chamorro, S., Sainz, A., Nicodemus, N., de Blas, C., Carabaño R., 2008. Effect of dietary level and source of glutamine on intestinal health in the postweaning period. In Proc: 9th World Rabbit Congress, Verona, Italy. p. 10-13.

Bennegadi, N., Fonty, G., Millet, L., Gidenne, T., Licois, D. 2003. Effects of age and dietary fibre level on caecal microbial communities of conventional and specific pathogen-free rabbits. Microb. Ecol. Health Dis. 15, 23-32.

Berard, J., Kreuzer, M., Bee, G., 2009. Effect of dietary arginine supplementation to sows on litter size, fetal weight and myogenesis at d 75 of gestation. J. Anim. Sci 87, 30.

Berard, J., Bee, G., 2010. Effect of dietary L-arginine supplementation to gilts during early gestation on foetal survival, growht and myofiber formation. Animal 4, 1680-1687.

Bergaoui, R., Kammoun, M., Ouerdiane, K., 2008. Effects of feed restriction on the performance and carcass of growing rabbits. In Proc: 9th World Rabbit Congress, Verona, Italy. p. 547-550.

Bernardini, M., Dal Bosco, A., Castellini, C., 1999. Effect of dietary n-3/n-6 ration on fatty acid composition of liver, meat and perirenal fat in rabbits. Anim. Sci. 68, 647-654.

Beutheu, S., Ouelaa, W., Guérin, C., Belmonte, L., Aziz, M., Tennoune, N., Bôle-Feysot, C., Galas, L., Déchelotte, P., Coëffier, M., 2014. Glutamine supplementation, but not combined glutamine and arginine supplementation, improves gut barrier function during chemotherapy-induced intestinal mucositis in rats. Clin. Nutr. 33, 694-701.

Bird, I.M., Zhang, L., Magness, R.R., 2003. Possible mechanisms underlying pregnancyinduced changes in uterine artery endothelial function. Am. J. Physiol. Regul. Integr. Comp. Physiol. 284, 245-258.

Bivolarski, B.L., Vachkova, E.G., 2014. Morphological and functional events associated to weaning in rabbits. J. Anim. Physiol. Anim. Nutr. 98, 9-18.

Blasco, A., Bidanel, J.P., Bolet, G., Haley, C.S., Santacreu, M.A., 1993. The genetic of prenatal survival of pigs and rabbits: a review. Livest. Prod. Sci. 37, 1-21.

Boletín Oficial del Estado (BOE) 2013. Real Decreto 53/2013. Normas básicas aplicables para la protección de los animales utilizados en experimentación y otros fines científicos, incluyendo la docencia. BOE 34, 11370-11421. 
Boudry, G., Douard, V., Mourot, J., Lallès J.P., Le Huërou-Luron, I., 2009. Linseed oil in the maternal diet during gestation and lactation modifies fatty acid composition, mucosal architecture, and mast cell regulation of the ileal barrier in piglets. J. Nutr. 139, 1110-1117.

Boulahrouf, A., Fonty, G., Gouet, P. 1991. Establishment, counts and identification of the fibrolytic bacteria in the digestive tract of rabbit. Influence of feed cellulose content. Curr. Microbiol. 22, 1-25.

Bredt, D., Snyder, S., 1994. Nitric oxide: a physiologic messenger molecule. Annu. Rev. Biochem. 63, 175-195.

Brenna, J.T., 2002. Efficiency of conversion of $\alpha$-linolenic acid to long chain n-3 fatty acids in man. Curr. Opin. Clin. Nutr. Metab. Care. 5, 127-132.

Brooks, H.W., White, D.G., Wagstaff, A.J., 1997. Evaluation of a glutamine-containing ral dehydration solution for the treatment of calf diarrhea using an Escherichia coli model. Br. Vet. J. 153, 163-170.

Bruewer, M., Luegering, A., Kucharzik, T., Park, ChA., Madara, J.L., Hopkins, A.M., Nusrat, A., 2003. Proinflammatory cytokines disrupt epithelial barrier function by apoptosis-independent mechanisms. J. Immunol. 171, 6164-6172.

Brunsgaard, G., 1997. Morphological characteristics, epithelial cell proliferation, and crypt fission in cecum and colon of growing pigs. Dig. Dis. Sci. 42, 2384-2393.

Burdge, G.C., Wootton, S.A., 2002. Conversion of $\alpha$-linolenic acid to eicosapentaenoic, docosapentaenoic and docosahexaenoic acids in young women. Br. J. Nutr. 88, 411-420.

Burkey, T.E., Skjolaas, K.A., Minton, J.E., 2009. Porcine mucosal immunity of the gastrointestinal tract. J. Anim. Sci. 87, 1493-1501.

Calder, P.C., 1996. Immunomodulatory and anti-inflammatory effects of n-3 polyunsaturated fatty acids. Proc. Nutr. Soc. 55, 737-774.

Calder, P.C., 2001. Polyunsaturated fatty acids, inflammation, and immunity. Lipids. 36, 1007-1024.

Calder, P.C., Kew, S., 2002. The immune system: a target for functional foods?. Br. J. Nutr. 88, 165-176.

Calder P.C., 2003. N-3 polyunsaturated fatty acids and inflammation: from molecular biology to the clinic. Lipids. 38, 343-352. 
Calder, P.C., 2008. Polyunsaturated fatty acids, inflammatory processes and inflammatory bowel diseases. Mol. Nutr. Food Res. 52, 885-897.

Campín, J., Eiras, P., Rebollar, P.G., Carabaño, R., 2003. Estudio del tejido linfoide asociado a intestino en gazapos en torno al destete. In: V Jornadas sobre Producción Animal, Zaragoza, Spain. 24, 660-662.

Campoy, C., Escolano-Margarit, M.V., Anjos, T., Szajewska, H., Uauy, R., 2012. Omega 3 fatty acids on child growth, visual acuity and neurodevelopment. Br. J. Nutr. 107, 85-106.

Carabaño, R., Motta-Ferreira, W., de Blas, J.C., Fraga, M.J., 1997. Substitution of sugarbeet pulp for alfalfa hay in diets for growing rabbits. Anim. Feed Sci. Technol. 65, 249-256.

Carabaño, R., Piquer, J., Menoyo, D., Badiola, I., 1998. The digestive system of the rabbit, in: De Blas C., Wiseman J., (Eds.), Nutrition of the rabbit, CABI Publishing CAB International, Wallingford, UK. pp 1-16.

Carabaño R., de Blas C., García A.I., 2000. Recent advances in nitrogen nutrition in rabbits. World Rabbit Sci. 8, 14-28.

Carabaño, R., García, J., de Blas, J.C., 2001. Effect of fibre source on ileal apparent digestibility of non-starch polysaccharides in rabbits. Anim. Sci. 72, 343-350.

Carabaño, R., Badiola, I., Licolis, D., Gidenne, T., 2006. The digestive ecosystem and its control through nutritional or feeding strategies, in: Maertens L., Coudert P. (Eds.), Recent advances in rabbit sciences, ilvo., Merenbeke, Belgium. pp. 221227.

Carabaño, R., Badiola, I., Chamorro, S., García, J., García-Ruiz, A., García-Rebollar, P., Gómez-Conde, M.S., Gutiérrez, I., Nicodemus, N., Villamide, M.J., De Blas, J.C., 2008. New trends in Rabbit feeding: influence of nutrition on intestinal health. Span. J. Agric. Res. 6, 15-25.

Carney, E.W., Bavister, B.D., 1987. Stimulatory and inhibitory effects of amino acids on the development of hamster eight-cell embryos in vitro. J. In Vitro Fertil. Embryo Transfer 4, 162-167.

Cartuche, L., Pascual, M., Gómez, E.A., Blasco, A., 2014. Economic weights in rabbit meat production. World Rabbit Sci. 22, 165-177. 
Casado, C., Moya, V.J., Pascual, J.J., Blas, E., Cervera, C. 2013. Dietary fatty acid profile: effects on caecal fermentation and performance of young and fattening rabbits. World Rabbit Sci. 21, 235-242.

Castellini, C., Dal Bosco, A., Cardinali, R., Mugnai, C., Sciascia, E., 2004. Effect of dietary N-3 fatty acids on the composition of doe's milk and tissues of suckling rabbits. In: 8th World Rabbit Congress, Puebla, México. p. 7-10.

Caughey, G.E., Mantzioris, E., Gibson, R.A., Cleland, L.G., James, M.J., 1996. The effect on human tumor necrosis factor alpha and interleukin 1 beta production of diets enriched in n-3 fatty acids from vegetable oil or fish oil. Am. J. Clin. Nutr. 63, 116-122.

Chamorro, S., Gómez-Conde, M.S., Pérez de Rozas, A.M., Badiola, I., Carabaño, R., De Blas, J.C., 2007. Effect on digestion and performance of dietary protein content and of increased substitution of lucerne hay with soya-bean protein concentrate in starter diets for young rabbits. Anim. 1, 651-659.

Chamorro, S., de Blas, C., Grant, G., Badiola, I., Menoyo, D., Carabano, R., 2010. Effect of dietary supplementation with glutamine and a combination of glutaminearginine on intestinal health in twenty-five-day-old weaned rabbits. J. Anim. Sci. 88, 170-180.

Chokshi, N.K., Guner, Y.S., Hunter, C.J., Upperman, J.S., Grishin, A., Ford, H.R., 2008. The role of nitric oxide in intestinal epithelial injury and restitution in neonatal necrotizing enterocolitis. Semin. Perinatol. 32, 92-99.

Chun, H., Sasaki, M., Fujiyama, Y., Bamba, T., 1997. Effect of enteral glutamine on intestinal permeability and bacterial translocation after abdominal radiation injury in rats. J. Gastroenterol. 32, 189-195.

Coeffier, M., Miralles-Barrachina, O., Le Pessot, F., Lalaude, O., Daveau, M., Lavoinne, A., Lerebours, E., Dechelotte, P., 2001. Influence of glutamine on cytokine production by human gut in vitro. Cytokine. 13,148-154.

Coëffier, M., Marion, R., Ducrotte, P., Dechelote, P., 2003. Modulating effect of glutamine on IL-1 beta-induced cytokine production by human gut. Clin. Nutr. 22, 407-413.

Coëffier, M., Marion-Letellier, R., Déchelotte, P., 2010. Potential for amino acids supplementation during inflammatory bowel diseases. Inflamm. Bowel Dis. 16, 518-524. 
Colin, M., 1975. Effet de la teneur en arginine du régime sur la croissance et le bilan azoté chez le lapin: Relation avec le taux de lisine. Ann. Zootech. 24, 629-638.

Combes, S., Michelland, R.J., Monteils, V., Cauquil, L., Soulié, V., Tran, N.U., Gidenne, T., Fortun-Lamothe, L., 2011. Postnatal development of the rabbit caecal microbiota composition and activity. FEMS Microbiol. Ecol. 77, 680-689.

Combes, S., Gidenne, T., Cauquil, L., Bouchez, O., Fortun-Lamothe, L., 2014. Coprophagous behaviour of rabbit pups affects implantation of cecal microbiota and health status. J. Anim. Sci. 92, 652-665.

Corrigan, A., Horgan, K., Clipson, N., Murphy, R.A., 2011. Effect of dietary supplementation with a Saccharomyces cerevisiae mannan oligosaccharide on the bacterial community structure of broiler cecal contents. Appl. Environ. Microbiol. $77,6653-6662$.

Corson, A.M., Laws, J., Litten, J.C., Dodds, P.F., Lean, I.J., Clarke, L., 2008. Effect of dietary supplementation of different oils during the first or second half of pregnancy on the glucose tolerance of the sow. Anim. 2, 1045-1054.

Curi, R., Lagranha, C.J., Doi, S.Q., Sellitti, D.F., Procopio, J., Pithon-Curi, T.C., Corless, M., Newshome, P., 2005. Molecular mechanisms of glutamine action. J. Cell. Physiol. 204, 392-401.

Dai, Z.L., Li, X.L., Xi, P.B., Zhang, J., Wu,G., Zhu, W.Y., 2013. L-Glutamine regulates amino acid utilization by intestinal bacteria. Amino Acids. 45, 501-512.

Dal Bosco, A., Castellini, C., Bianchi, L., Mugnai, C., 2004. Effect of dietary $\alpha$-linolenic acid and vitamin $\mathrm{E}$ on the fatty acid composition, storage stability and sensory traits of rabbit meat. Meat Sci. 66, 407-413.

Damico, J., Torres, C., Argente, M.J., García, M.L. 2013. Study of uterine and foetal traits of the rabbit female at 12 days of gestation. World Rabbit Sci. 21, 209-210.

Dasso, J.F., Howell, M.D., 1997. Neonatal appendectomy impairs mucosal immunity in rabbits. Cell. Immunol. 182, 29-37.

Dasso, J.F., Obiakor, H., Bach, H., Anderson, A.O., Mage, R.G., 2000. A morphological and immunohistological study of the human and rabbit appendix for comparison with the avian bursa. Develop. Comp. Immunol. 24, 797-814.

Daza, A., Mateos, A., Rey, A. I., Ovejero, I., Lopez-Bote, C.J., 2007. Effect of duration of feeding under free-range conditions on production results and carcass and fat quality in Iberian pigs. Meat Sci. 76, 411-416. 
De Blas, C., Wiseman, J., Fraga, M.J., Villamide, M.J., 1992. Prediction of the digestible energy and digestibility of gross energy of feeds for rabbits. 2. Mixed diets. Anim. Feed Sci. Technol. 39, 39-59.

De Blas, J.C., Carabaño, R., 1996. Areview on the energy value of sugar beet pulp for rabbits. World Rabbit Sci. 4, 33-36.

De Blas, J.C., Gutiérrez, I., Carabaño, R., 1999a. Destete precoz en gazapos. Situación actual y perspectivas. In: XV Curso de Especialización FEDNA, Madrid, Spain. p. 67-81.

De Blas, C., García, J., Carabaño, R., 1999b. Role of fibre in rabbit diets. A review. Ann. Zootech. 48, 3-13.

De Blas, C., Mateos, G.G., 2010. Feed formulation, in: De Blas, C., Wiseman, J. (Eds.), Nutrition of the rabbit. 2nd edition. CABI Publishing CAB International, Wallingford, UK. pp. 222-232.

De Lange, C.F.M., Pluske, J., Gong, J., Nyachoti, C.M., 2010. Strategic use of feed ingredients and feed additives to stimulate gut health and development in young pigs. Livest. Sci. 134, 124-134.

Delgado, R., Badiola, I., Abad-Guamán, R., Nicodemus, N., Villamide, M.J., Pérez de Rozas, A., Menoyo, D., Carabaño, R., García, J., 2015b. Effect of level of soluble fibre and omega-6/omega-3 ratio on microbiota colonisation in suckling rabbits. World Rabbit Sci. 23, 131.

Delgado, R., Menoyo, D., Abad-Guamán, R., Nicodemus, N., Carabaño, R., García J. 2015a. Efecto del nivel de fibra soluble y de la relación omega-6/omega-3 sobre los rendimientos productivos de gazapos en cebo. In: XVI Jornadas sobre Producción Animal, Zaragoza, Spain. 1, 284-286.

Denker, H.W., 1977. Implantation. The role of proteinases, and blockage of implantation by proteinase inhibitors.Adv. Anat. Embryol. Cell Biol. 53, 3-123.

Deplancke, B., Gaskins, H.R. 2001. Microbial modulation of innate defense: goblet cells and the intestinal mucus layer. Am. J. Clin. Nutr. 73, 1131-1141.

Dewrée, R., Meulemans, L., Lassence, C., Desmecht, D., Ducatelle, R., Mast, J., Licois, D., 2010. Experimentally induced epizootic rabbit enteropathy: clinical, histopathologicaI, ultrastructural, bacteriological and haematological findings. World Rabbit Sci. 15, 91-102. 
Donnet-Hughes, A., Perez, P.F., Doré, J., Leclerc, M., Levenez, F., Benyacoub, J., Serrant, P., Segura-Roggero, I., Schiffrin, E.J., 2010. Potential role of the intestinal microbiota of the mother in neonatal immune education. Proc. Nutr. Soc. 69, 407-415.

Donnet-Hughes, A., Pérez, P.F., Doré, J., Leclerc, M., Levenez, F., Benyacoub, J., Serrant, P., Segura-Roggero, I., Schiffrin, E.J., 2010b. Prebiotics and probiotics usefulness against pathologies. Potential Role of the intestinal microbiota of the mother in neonatal immune education. Proc. Nutr. Soc. 69, 407-415.

Drackey, J.K., Blome, R.M., Bartlett, K.S., Bailey, K.L., 2006. Supplementation of 1\% L-glutamine to milk replacer does not overcome the growth depression in calves caused by soy protein concéntrate. J. Dairy Sci. 89, 1688-1693.

Druart, C., Neyrinck, A.M., Vlaeminck, B., Fievez, V., Cani P.D., Delzenne, N.M., 2014. Role of the lower and upper intestine in the production and absorption of gut microbiota-derived PUFA metabolites. PLoS ONE 9: e87560.

Duggan, C., Gannon, J., Walker, W.A., 2002. Protective nutrients and functional foods for the gastrointestinal tract. Am. J. Clin. Nutr. 75, 789-808.

Duncan, S.L.B., 1969. The partition of uterine blood flow in pregnant rabbit. J. Physiol. 204, 421-433.

Duttaroy, A.K., 2009. Transport of fatty acids across the human placenta: a review. Prog. Lipid Res. 48, 52-61.

El Abed, N., Delgado, R., Abad, R., Romero, C., Villamide, M.J., Menoyo, D., Carabaño, R., García, J., 2011. Soluble and insoluble fibre from sugar beet pulp enhance intestinal mucosa morphology in young rabbits. In: $62^{\text {nd }}$ Annual meeting of the European Federation of Animal Science. Wageningen Academic Publishers. Stavanger, Norway. P 159.

El Abed, N., Badiola, I., Pérez de Rozas, A Gonzáles, J., Menoyo, D., Carabaño, R., García, J., 2013. Effect of soluble and insoluble fraction of sugar beet pulp on ileal and caecal Microbiota. Word Rabbit Sci. 21, 207-208.

Ewtushik, A.L., Bertolo, R.F.P., Ball, R.O., 2000. Intestinal development of early-weaned piglets receiving diets supplemented with selected amino acids or polyamines. Can. J. Anim. Sci. 80, 653-662. 
Falcao e-Cunha, L., Peres, H., Freire, J.P.B., Castro-Solla, L., 2004. Effects of alfalfa, wheat bran or beet pulp, with or without sunflower oil, on caecal fermentation and on digestibility in the rabbit. Anim. Feed Sci. Technol. 117, 131-149.

Feller, S.E., Gawrisch, K., MacKerell, A.D., 2002. Polyunsaturated fatty acids in lipid bilayers: intrinsic and environmental contributions to their unique physical properties. J. Am. Chem. Soc. 124, 318-326.

Ferguson, F.A., Lukefahr, S.D., Mcnitt, J.L., 1997. A technical note on artificial milk feeding of rabbit kits weaned at 14 days. World Rabbit Sci. 5, 65-70.

Fernández, L., Langa, S., Martín, V., Maldonado, A., Jiménez, E., Martín, R., Rodríguez, J.M., 2013. The human milk microbiota: origin and potential roles in health and disease. Pharmacol. Res. 69, 1-10.

Feugier, A., Smit, M.N., Fortun-Lamothe, L., Gidenne, T., 2006. Fibre and protein requirements of early-weaned rabbits and the interaction with weaning age: effects on digestive health and growth performance. Anim. Sci. 82, 493-500.

Field, C.J., Wu, G., Marliss, E.B., 1994. Enhanced metabolism of glucose and glutamine in mesenteric lymph node lymphocytes from spontaneously diabetic BB rats. Can. J. Physiol PharmacoL. 72, 827-832.

Flynn, N.E.,Wu, G., 1997. Glucocorticoids play an important role in mediationg the enhanced metabolism of arginine and glutamine in enterocytes of postweaning pigs. J. Nutr. 127, 732-737.

Forsythe, S.J., Parker, D.S., 1985. Nitrogen metabolism by the microbial flora of the rabbit caecum. J. Appl. Bacteriol. 58, 363-369.

Fortun-Lamothe, L., 2006. Energy balance and reproductive performance in rabbit does. Anim. Reprod. Sci. 93, 1-15.

Fraga, M.J., Pérez, P., Carabaño, R., de Blas, J.C., 1991. Effect of type of fibre on the rate of passage and on the contribution of soft feces to nutrient intake of finishing rabbits. J. Anim. Sci. 69, 1566-1574.

Fu, W.J., Haynes, T.E., Kohli, R., Hu, J., Shi, W., Spencer, T. E., Carroll, R.J., Meininger, C.J., Wu, G., 2005. Dietary L-arginine supplementation reduces fat mass in Zucker diabetic fatty rats. J. Nutr. 135, 714-721.

Furness, J.B., Rivera, L.R., Cho, H.J., Bravo, D.M., Callaghan, B., 2013. The gut as a sensory organ. Nat. Rev. Gastroenterol. Hepatol. 10, 729-740. 
Gabler, N.K., Spencer, J.D., Webel, D.M., Spurlock, M.E., 2007. In utero and postnatal exposure to long chain (n-3) PUFA enhances intestinal glucose absorption and energy stores in weanling pigs. J. Nutr. 137, 2351-2358.

Gallois, M., Gidenne, T., Fortun-Lamothe, L., Huerou-Luron, I.L., Lalles, J.P., 2005. An early stimulation of solid feed intake slightly influences the morphological gut maturation in the rabbit. Reprod. Nutr. Dev. 45, 109-122.

Gallois, M., Gidenne, T., Tasca, C., Caubet, C., Coudert, C., Milon, A., Boullier, S., 2007. Maternal milk contains antimicrobial factors that protect young rabbits from enteropathogenic Escherichia coli infection. Clin. Vaccine Immunol. 14, 585-592.

Gallois, M., Huërou-Luron, I.L., Fortun-Lamothe, L., Lalles, J.P., Gidenne, T., 2008. Adaptability of the digestive function according to age at weaning in the rabbit: I. Effect on feed intake and digestive functionality. Anim. 2, 525-535.

Gaman, E., Fisher, H., 1970. The essentiality of arginine, lysine and methionine for the growing rabbit. Nutr. Rep. Int. 1, 57-64.

Gao, H., Wu, G., Spencer, T.E., Johnson, G. A., Li, X., Bazer, F.W., 2009. Select Nutrients in the Ovine Uterine Lumen. I. Amino Acids, Glucose, and Ions in Uterine Lumenal Flushings of Cyclic and Pregnant Ewes 1. Biol. Reprod. 80, 8693.

García, G., Gálvez, J.F., de Blas, J.C. 1992a. Substitution of barley grain by sugar-beet pulp in diets for finisnhing rabbits. 1. Effect on energy and nitrogen balance. J. Appl. Rabbit Res. 15, 1008-1016.

García, G., Gálvez, J.F., de Blas, J.C. 1992b. Substituion of barley grain by sugar-beet pulp in diets for finishing rabbits. 2. Effect on growth performance. J. Appl. Rabbit Res. 15, 1017-1024.

García, G., Gálvez, J.F., de Blas, J.C. 1993. Effect of substitution of sugarbeet pulp for barley in diets for finishing rabbits on growth performance and on energy and nitrogen efficiency. J. Anim., 71, 1823-1830.

García, J., Carabaño, R., De Blas, J.C., 1999. Effect of fiber source on cell wall digestibility and rate of passage in rabbits. J. Anim. Sci. 77, 898-905.

García, J., Carabaño, R., Pérez-Alba, L., De Blas, J.C., 2000. Effect of fiber source on cecal fermentation and nitrogen recycled through cecotrophy in rabbits. J. Anim. Sci. 78, 638-646. 
García, J., Nicodemus, N., Carabaño, R., Villamide, M.J., de Blas, C., 2001. Determination of the number of replicates required to detect a significant difference between two means in rabbit traits. World Rabbit Sci. 9, 27-32.

García, J., Gidenne, T., Falcao e-Cunha, L., De Blas, J.C., 2002. Identification of the main factors that influence caecal fermentation traits in growing rabbits. Anim. Res. 51, 165-173.

García, A.I., De Blas, J.C., Carabaño, R., 2005. Comparison of different methods for nitrogen and amino acid evaluation in rabbit diets. Anim. Sci. 80.

Garcia-Barrios, A., Gascon, S., Rodriguez-Yoldi, M.J., 2013. The effect of cytokines on intestinal sugar absorption during sepsis in rabbits. Res. Vet. Sci. 95, 482-482.

García-Palomares, J., Carabaño, R., García-Rebollar, P., De Blas, J.C., Corujo, A., 2010. Effects of dietary protein reduction and enzyme supplementation on growth performance in fattening period. World Rabbit Sci. 14, 231-236.

García-Ruiz, A.I., García-Palomares, J., García-Rebollar, P., Chamorro, S., Carabaño, R., De Blas, C., 2006. Effect of protein source and enzyme supplementation on ileal protein digestibility and fattening performance in rabbits. Span. J. Agric. Res. 4, 297-303.

Garrido, S., Nicodemus, N., García, J., Chamorro, S., De Blas, J.C., 2009. Effect of breeding system and farm hygiene on performances of growing rabbits and lactating does over two reproductive cycles. World Rabbit Sci. 17, 71-78.

Gavin, A., Ostovar, K., 1977. Microbiological characterization of human milk. J. Food Prot. 40, 614-616.

Gennari, R., Alexander, J.W., Eaves-Pyles, T., 1995. Effect of different combinations of dietary additives on bacterial translocation and survival in gut-derived sepsis. J. Parenter. Enteral Nutr. 19, 319-325.

Gerfault, V., Mourot, J., Etienne, M., Mounier, A., Peiniau, P., 1999. Influence de la nature des lipides dans le régime de gestation de la truie sur ses performances et la composition corporelle des porcelets à la naissance. Journées Rech. Porcine en France, 31, 191-198.

Gidenne, T., Poncet, C., Gomez, L., 1987. Effet de l'addition dun concentré riche en fibres dans une ration a base de foin, distribuee a deux niveaux alimentaires chez la lapine adulte. 1. Temps de sejour moyen des aliments. Reprod. Nutr. Develop. 27, 733-743. 
Gidenne, T., Pinheiro, V., Falcão e Cunha, L., 2000. A comprehensive approach of the rabbit digestion: consequences of a reduction in dietary fibre supply. Livest. Prod. Sci. 64, 3225-3237.

Gidenne, T., Fortun-Lamothe, L., 2002. Feeding strategy for young rabbits around weaning: a review of digestive capacity and nutritional needs. Anim. Sci. 75, 169184.

Gidenne, T., Jehl, N., Segura, M., Michalet-Doreau, B., 2002. Microbial activity in the caecum of the rabbit around weaning: impact of a dietary fibre deficiency and of intake level. Anim. Feed Sci. Technol. 99, 107-118.

Gidenne, T., Combes, S., Feugier, A., Jehl, N., Arveux, P., Boisot, P., Briens, C., Corrent, E., Fortune, H., Montessuy, S., Verdelhan, S., 2009. Feed restriction strategy in the growing rabbit. 2. Impact on digestive health, growth and carcass characteristics. Anim. 3, 509-515.

Gidenne, T., Carabaño, R., García, J., de Blas, C., 2010. Fibre Digestion. in: De Blas, C., Wiseman, J. (Eds.), Nutrition of the rabbit. 2nd edition. CABI Publishing CAB International, Wallingford, UK. pp. 66-82.

Gidenne, T., Combes, S., Fortun-Lamothe., L., 2012. Feed intake limitation strategies for the growing rabbit: effect on feeding behavior, welfare, performance, digestive physiology andhealth: a review. Anim. 6, 1407-1419.

Gidenne, T., Kerdiles, V., Jehl, N., Arveux, P., Eckenfelder, B., Briens, C., Stephan, S., Fortune, H., Montessuy, S., Muraz, G., 2013. Protein replacement by digestible fibre in the diet of growing rabbits: 2-Impact on performances, digestive health and nitrogen output. Anim. Feed Sci. Technol. 183, 142-150.

Gidenne, T., 2015. Dietary fibres in the nutrition of the growing rabbit and recommendations to preserve digestive heath: a review. Anim. 9, 227-242.

Godornes, C., Leader, B.T., Molini, B.J., Centurion-Lara, A., Lukehart, S.A., 2007. Quantitation of Rabbit Cytokine mRNA by Real-Time RT-PCR. Cytokine. 38, 17.

Goehring, H.K., Van Soest, P.J., 1970. Forage fiber analyses (apparatus, reagents, procedures and someapplications). Agric. Handbook n 379. ARS, USDA, Washington, DC.

Gómez-Conde, M.S., García, J., Chamorro, S., Eiras, P., García-Rebollar, P., Pérez de Rozas, A., Badiola, I., De Blas, J.C., Carabaño, R., 2007. Neutral detergent- 
soluble fibre improves gut barrier function in twenty-five-day-old weaned rabbits. J. Anim. Sci. 85, 3313-3321.

Gómez-Conde M.S., Pérez de Rozas A., Badiola I., Pérez-Alba L., de Blas C., Carabaño R., García J. 2009. Effect of neutral detergent soluble fibre on digestion, intestinal microbiota and performance in twenty five day old weaned rabbits. Livest. Sci. 125, 192-198.

González-Mariscal, G., 2007. Mother rabbits and their offspring: timing is everything. Dev Psychobiol. 49, 71-76.

Gouet, P., Fonty, G., 1973. Evolution de la microflore digestive du lapin holoxénique de la naissance au sevrage. Ann. Biol. Anim. Biochim. Biophys. 13, 753-735.

Gouet, P., Fonty, G., 1979. Changes in the digestive microflora of holoxenic rabbits from birth until adulthood. Ann. Biol. Anim. Biochim. Biophys.19, 553-556.

Greenberg, S.S., Lancaster, J.R., Xie, J., Sarphie, T.G., Zhao, X., Hua, L., Freeman, T., Kapusta, D.R., Giles, T.D., Powers, D.R., 1997. Effects of NO synthase inhibitors, arginine-deficient diet, and amiloride in pregnant rats. Am. J. Physiol. Regul. Integr. Comp. Physiol. 273, 1031-1045.

Greenberg, J.A., Bell, S.J., Van Ausdal, W., 2008. Omega-3 fatty acid supplementation during pregnancy. Rev. Obstet. Gynecol. 1, 162-169.

Greiner, L., Usry, J.L., Neill, C., et al., 2012 The evaluation of supplemental 1-arginine during gestation on sow reproductive performance. J Anim Sci 90 (Suppl 2): 3334 (Abstract).

Gutiérrez, I., Espinosa, A., García, J., Carabaño, R., De Blas, J.C., 2002. Effect of the levels of starch, fibre and lactose on digestion and growth performance of early weaned rabbits. J. Anim. Sci. 80, 1029-1037.

Gutiérrez, I., Espinosa, A., García, J., Carabaño, R., De Blas, C., 2003. Effect of protein source on digestion and growth performance of early-weaned rabbits. Anim. Res. 52, 461-471.

Gutiérrez, M., 2009. Desarrollo de nuevos criterios inmunitarios de la barrera intestinal en conejos. Trabajo fin de carrera. Departamento de Producción animal, ETSIA, Universidad Politécnica de Madrid.

Gwatkin, R.B.L., Haidri, A.A., 1973. Requirements for the maturation of hamster oocytes in vitro. Exp. Cell. Res. 73, 1-7.

Hall, M.B., 2003. Challenges with non-fibre methods. J. Anim. Sci. 81, 3226-3232. 
Hampson, D.J., 1986. Alteration in piglet small intestinal structure at weaning. Res. Vet. Sci. 40, 32-40.

Hanczakowska, E., Niwińska, B., 2013. Glutamine as a Feed Supplement for Piglets: a Review/Glutamina jako dodatek do paszy dla prosiąt: przegląd. Ann. Anim. Sci. $13,5-152$.

Hanson, N.B., Lanning, D.K., 2008. Microbial induction of B and T cell areas in rabbit appendix. Develop. Comp. Immunol. 32, 980-991.

Harbige L.S., 2003. Fatty acids, the immune response, and autoimmunity: a question of n-6 essentiality and the balance between n-6 and n-3. Lipids. 38, 323-341.

Harper, M.J., 1961. The time of ovulation in the rabbit following the injection of luteinizing hormone. J. Endocrinol. 22, 147-152.

Hassan, A., Ibrahim, A., Mbodji, K., Coëffier, M., Ziegler, F., Bounoure, F., Chardigny, J., Skiba, M., Savoye, G., Déchelotte, P., Marion-Letellier, R., 2010. An $\alpha-$ linolenic acid-rich formula reduces oxidative stress and inflammation by

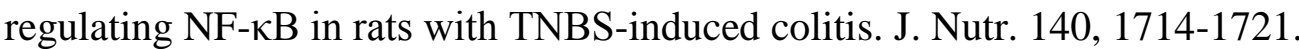

Healy, D.A., Wallace, F.A., Miles, E.A., Calder, P.C., Newsholme, P., 2000. Effect of low-to-moderate amounts of dietary fish oil on neutrophil lipid composition and function. Lipids. 35, 763-768.

Hedemann, M., Eskildsen, M., Laerke, H., Pedersen, C., Lindberg, J., Laurinen, P., Bach Knudesen, K., 2006. Intestinal morphology and enzymatic activity in newly in newly weaned pigs fed contrasting fibre concentration and fibre properties. J. Anim. Sci. 84, 1375-1386.

Heikkila, MP, Saris, P.E., 2003. Inhibition of Staphylococcus aureus by the commensal bacteria of human milk. J. App. Microbiol. 95, 471-478.

Hill, R.R.H., 1986. Digestion of mucin polysaccharides in vitro by bacteria isolated from the rabbit cecum. Curr. Microbiol. 14, 117-120.

Hong, J., Lee, E., 2007. Intrafollicular amino acid concentration and the effect of amino acids in a defined maturation medium on porcine oocyte maturation, fertilization, and preimplantation development. Theriogenology. 68, 728-735.

Houghteling, P.D., Walker, W.A., 2015. Why is initial bacterial colonization of the intestine important to the infant's and child's health?. J. Pediatr. Gastroenterol. Nutr. 60, 294-307. 
Hoy, St., Selzer, D., 2002. Frequency and time of nursing in wild and domestic rabbits housed outdoors in free range. World Rabbit Sci. 10, 77-84.

Hu, C.H., Xiao, K,, Luan, Z.S., Song, J., 2013. Early weaning increases intestinal permeability, alters expression of cytokine and tight junction proteins, and activates mitogen-activated protein kinases in pigs. J. Anim. Sci. 91, 1094-1101.

Innis, S.M., 1991. Essential fatty acids in growth and development. Prog. Lipid Res. 30, 39-103.

Innis, S.M., 2007. Dietary (n-3) fatty acids and brain development. J. Nutr. 137, 855-859.

INRA., 1984. L'alimentation des animaux monogastriques: Porc, Lapin, Volailles, in: Blum, J.C., (Ed.), Institute de la Recherche Agronomique, Paris, France.

Ipharraguerre, I.R., Tedó, G., Menoyo, D., de Diego, N., Holst, J.J., Nofrarías, M., 2013. Bile acids induce glucagon-like peptide 2 secretion with limited effects on intestinal adaptation in early weaned pigs. J. Nutr. 143, 1899-905.

Ishida, T., Yoshida, M., Arita, M., Nishitani, Y., Nishiumi, S., Masuda, A., Mizuno, S., Takawaka, T., Morita, Y., Kutsumi, H., Inokuchi, H., Serhan, C.N., Blumberg, R.S. Azuma, T., 2010. Resolvin E1, an endogenous lipid mediator derived from eicosapentaenoic acid, prevents dextran sulfate sodium-induced colitis. Inflamm. Bowel Dis. 16, 87-95.

Ito, H., Satsukawa, M., Arai, E., Sugiyam, K., Sonoyama, K., kiriyama, S., Morita, T., 2009. Soluble fibre viscosity affects both goblet cell number and small intestine mucin secreion in rats. J. Nutr. 139, 1640-1647.

Jeklova, E., Leva, L., Kudlackova, H., Faldyna, M., 2007a. Functional development of immune response in rabbits. Vet. Immunol. Immunopathol. 118, 221-228.

Jeklova, E., Leva, L., Faldyna, M., 2007b. Lymphoid organ development in rabbits: major lymphocyte subsets. Dev. Comp. Immunol. 31, 632-644.

Jensen, M. M., Skarsfeldt, T., Hoy, C.E., 1996. Correlation between level of $(n-3)$ polyunsaturated fatty acids in brain phospholipids and learning ability in rats. A multiple generation study. Biochim. Biophys. Acta, Lipids Lipid Metab. 1300, 203-209.

Jinquan, T., Larsen, C.G., Gesser, B., Matsushima, K., Thestrup-Pedersen, K., 1993. Human IL-10 is a chemoattractant for CD8+ T lymphocytes and an inhibitor of IL-8-induced CD4+ T lymphocyte migration. J. Immunol. 151, 4545-4551. 
Johansson, M.E., Sjövall, H., Hansson, G.C., 2013. The gastrointestinal mucus system in health and disease. Nat. Rev. Gastroenterol. Hepatol. 10, 352-361.

Jones, C.S., Parker, D.S., 1981. The metabolism of glucose, acetate and palmitate in the lactating rabbit. Comp. Biochem. Physiol Part B: Comp. Biochem., 69, 837-842.

Józwik, M., Józwik, M., Teng, C., Battaglia, F.C., 2006. Amino acid, ammonia and urea concentrations in human pre-ovulatory ovarian follicular fluid. Hum. Reprod. 21, 2776-2782.

Kelley, D.S., Nelson, G.J., Serrato, C.M., Schmidt, P.C., Branch, L.B., 1988. Effects of type of dietary fat on incidences of immune status of rabbits. J. Nutr. 118, 1376-1384. Kelley, D.S., Nelson, G.J., Love, J.E., Branch, L.B., Taylor, P.C., Schmidt, P.C., Mackey, B.E., Iacono, J.M., 1993. Dietary $\alpha$-linolenic acid alters tissue fatty acid composition, but not blood lipids, lipoproteins or coagulation status in humans. Lipids. 28, 533-537.

Kelley, D.S., Taylor, P.C., Nelson, G.J., Mackey, B.E., 1998. Arachidonic acid supplementation enhances synthesis of eicosanoids without suppressing immune functions in young healthy men. Lipids. 33, 125-130.

Kelly, D., Conway, S., Aminov, R., 2005. Commensal gut bacteria: mechanisms of immune modulation. Trends Immunol. 26, 326-333.

Kew, S., Banerjee, T., Minihane, A.M., Finnegan, Y.E., Muggli, R., Albers, R., Williams, C.M., Calder, P.C., 2003. Lack of effect of foods enriched with plant-or marinederived $n-3$ fatty acids on human immune function. Am. J. Clin. Nutr. 77, 12871295.

Khan, J., Iiboshi, Y., Cui, L., Wasa, M., Sando, K., Takagi, Y., Okada, A., 1999. Alanylglutamine-supplemented parental nutrition increases luminal mucus gel and decreases permeability in the rat small intestine. J. Parenter. Enteral. Nutr. 23, 2431.

Kidd, K.T., Peebles, E.D., Whitmarsh, S.K., Yeatman, J.B., Wideman, R.F., 2001. Growth and immunity of broilers chicks as affected by dietary arginine. Poultry Sci. $80,1535-1542$.

Kiernan, J.A., 1999. Histological and Histochemical Methods: Theory and Practise. 3rd edition, in: Root, R.K., Waldvogel, F., Corey, L., Stamm, W.E. (Eds.), Oxford, Butterworths/Heinemann, UK. 
Kim, S.W., Mateo, R.D., Yin, Y.L., Wu, G.Y., 2007. Functional amino acids and fatty acids for enhancing production performance of sows and piglets. Asian Australas. J. Anim. Sci. 20, 295-306.

Kitt, S.J., Miller, P.S., Fischer, R.L., 2004. Supplementation on sow and litter performance, subsequent weanling pig performance and intestinal development after an immune challenge. Nebraska Swine Reports, 15.

Klasing, K.L. Calvert, C.C., 2000. The care and feeding of an immune system: an analysis of lysine needs. In: Lobley, G.E., White, A., MacRae, J.C. (Eds.), 8th International Symposium on Protein Metabolism and Nutrition. Wageningen Press, Netherlands, pp. 253-264.

Knight, K.L., Crane, M.A., 1994. Generating the antibody repertoire in rabbit. Adv. Immunol. 56, 179-218.

Knight, P.A., Wright, S.H., Lawrence, C.E., Paterson, Y.Y.W., Miller, H.R.P., 2000. Delayed expulsion of the nematode Trichinella spiralis in mice lacking the mucosal mast cell-specific granule chymase, mouse mast cell protease-1. J. Exp. Med. 192, 1894-1856.

Kooij, I.A., Sahami, S., Meijer, S.L., Buskens, C.J., te Velde, A.A., 2016. The immunology of the vermiform appendix: a review of the literature. Clin. Exp. Immunol. 186, 1-9.

Kovács, M., Szendrõ, Z., Milisits, G., Biro-Nemeth, E., Radnai, I., Posa, R., Bónai, A., Kovács, F., Horn. P., 2006. Effect of nursing method and faeces consumption on the development of bace-troides, lactobacillus and coliform flora in the caecum of the newborn rabbits. Reprod. Nutr. Dev. 46, 205-210.

Kul, M., Vurucu, S., Demerkaya, E., Tunc, T., Aydinoz, S., Meral, C., Kesik, V., Alpay, F., 2009. Enteral glutamine and/or arginine suplemmentation have favorable effects on oxidative stress parameters in neonatal rat intestine. J Pediatr Gastroenterol Nutr. 49, 85-89.

Kurlak, L.O., Stephenson, T.J., 1999. Plausible explanations for effects of long chain polyunsaturated fatty acids (LCPUFA) on neonates. Arch. Dis. Child. -Fetal Neonatal Ed. 80, 148-154.

Kyle, U.G., Bosaeus, I., De Lorenzo, A.D., Deurenberg, P., Elia, M., Gómez, J.M., Heitmann, B.L., Kent-Smith, L., Melchior, J.C., Pirlich, M., Scharfetter, H., 
Schols, A.M.W.J., Pichard, C., 2004. Biolectrical impedance analysis - part I: review of principles and methods. Clin. Nutr. 23, 1226-1243.

Lane, D.J., 1991. 16S/23S rRNA sequencing. in: E. Stackebrandt., M. Goodfellow., (Eds), Nucleic acid techniques in bacterial systematics. John Wiley and Sons, New York, USA. pp. 115-175

Lanning, D., Sethupathi, P., Rhee, K.J., Zhai, S.K., Knight, K.L., 2000. Intestinal microflora and diversification of the rabbit antibody repertoire. J. Immunol. 165, 2012-2019.

Lapillonne, A., 2007. Acides gras oméga-3 et oméga-6 au cours de la grossesse et de la petite enfance. Cah. Nutr. Diét. 42, 38-42.

Le Floc'h, N., Sève, B., 2000. Le devenir des protéines et des acides aminés dans l'intestine du porc: de la digestin à l'apparition dans la veine porte. Prod. Anim. 13, 303-314.

Lebas, F., 1970. Alimentation et croissance du Lapereau sous la mère. Rec. Med. Vet. 146, 1065-1070.

Lebas, F., Laplace, J.P., 1972. Mensurations viscérales chez le lapin. I. Croissance du foie, des reins et des divers segments intestinaux entre 3 et 11 semaines d'âge. Ann. Zootech. 21, 37-47.

Lebas, F., 1993. Amélioration de la viabilité des lapereaux en engraissement par un sevrage tardif. Cuniculture. 20, 73-75.

Lecleire, S., Hassan, A., Marion-Letellier, R., Antonietti, M., Savoye, G., Bole-Feysor, C., Lerebours, E., Ducrotte, P., Dehelotte, P., Coeffier, M., 2008. Combined glutamine and arginine decrease proinlammatory cytokine production by biopsies from Crohn's patients in association with changes in nuclear factor kappa B and p38. Mitogen-activated protein kinase pathways. J Nutr. 138, 2481-2486.

Lelkes, L., 1986. Mucoid enteritis - Overeating and microbial imbalance in the development of mucoid enteropathy in rabbits. J. Appl. Rabbit Res. 9, 148-151.

Leterme, P., Froidmont, E., Rossi, F., Thewis, A., 1998. The high water-holding capacity of pea inner fibers affects the ileal flow of endogenous amino acids in pigs. J. Agr. Food. Chem. 46, 1927-1934.

Li, N., Lewis, P., Samuelson, D., Liboni, K., Neu, J., 2004. Glutamine regulates Cacocell tight junction proteins. Am. J. Physiol. Gastrointest. Liver Physiol. 28, 726733. 
Li, P., Kim, S.W., Li, X.L., Datta, S., Pond, W.G., Wu, G., 2009. Dietary supplementation with cholesterol and docosahexaenoic acid affect concentrations of amino acids in tissues of young pigs. Amino Acids 37, 709-716.

Li, X.L., 2011. Regulation of porcine conceptus survival and growth by 1 -arginine. PhD dissertation, Texas A\&M University, College Station.

Licois, D., Wyers, M., Coudert, P., 2005. Epizootic rabbit enteropathy: Experimental transmission and clinical characterization. Vet. Res. 36, 601-613

Licois, D., Coudert, P., Marlier, D., 2006. Epizootic rabbit enteropathy. in: Maertens, L., Coudert, P. (Eds), Recent advances in rabbit sciences. p. 163.

Littell, R.C., Milliken, G.A., Stroup, W.W., Wolfinger, R.D., 1996. SAS System for mixed models. Cary, NC. SAS Institute Inc.

Littell, R.C, Henry, P.R., Ammerman, C.B., 1998. Statistical analysis of repeated measures data using SAS procedures. J. Anim. Sci. 76, 1216-1231.

Lobley, G.E., Hoskin, S.O., McNeil, C.J., 2001. Glutamine in animal science and production. J. Nutr. 131, 2525-2531.

Maertens, L., Luzi, F., De Groote, G., 1997. Effect of dietary protein and amino acids on the performance, carcass composition and $\mathrm{N}$-excretion of growing rabbits. Ann. Zootech. 46, 255-268.

Maertens, L., Aerts, J.M., de Brabander, D.L. 2005. Effect d'un aliment riche en acides gras omega-3 sur les performances et la composition du lait des lapines et la viabilité de leur descendance. In: 11 èmes Journées de la Recherche Cunicole. Melle, Belgium. p. 205-208.

Mage, R.G., Lanning, D., Knight, K.L., 2006. B cell and antibody repertoire development in rabbits: The requirement of gut-associated lymphoid tissues. Dev. Comp. Immunol. 30, 134-153.

Mantzioris, E., James, M.J., Gibson, R.A., Cleland, L.G., 1994. Dietary substitution with an alpha-linolenic acid-rich vegetable oil increases eicosapentaenoic acid concentrations in tissues. Am. J. Clin. Nutr. 59, 1304-1309.

Marlier, D., Dewrée, R., Lassence, C., Licois, D., Mainil, J., Coudert, P., Meulemans, L., Ducatelle, R., Vindevogel, H., 2006. Infectious agents associated with epizootic rabbit enteropathy: Isolation and attempts to reproduce the syndrome. Vet. J. 172, $493-500$ 
Marounek, M., Vovk, S.J., Skrinova, V., 1995. Distribution of activity of hydrolytic enzymes in the digestive tract of rabbits. Br. J. Nutr. 73, 463-469.

Marounek, M., Skrivanova, V., Duskova, D., 2000. In vitro caecal fermentation of nitrogenous substrates in rabbits. J. Agric. Sci. Camb. 135, 437-442.

Marounek, M., Skrivanova, E., Rada, V., 2003. Susceptibility of Escherichia coli to $\mathrm{C}_{2}$ $\mathrm{C}_{18}$ fatty acids. Folia Microbiol. 48, 731-735.

Martín, R., Langa, S., Reviriego, C., Jiménez, E., Marín, M.L., Olivares, M., Boza, J., Jiménez, J., Fernández, L., Xaus, J., Rodríguez, J.M., 2004. The commensal microflora of human milk: new perspectives for food bacteriotherapy and probiotics. Trends Food Sci. Technol. 15, 121-127.

Martínez-Vallespín, B., E. Martínez-Paredes, L. Ródenas, C. Cervera, J.J. Pascual, and E. Blas. 2011. Combined feeding of rabbit female and young: Partial replacement of starch with acid detergent fibre or/and neutral detergent soluble fibre at two protein levels. Livest. Sci. 141, 155-165.

Martínez-Vallespín, B., Martínez-Paredes, E., Ródenas, L., Moya, V.J., Cervera, C., Pascual, J.J., Blas, E., 2013. Partial replacement of starch with acid detergent fibre and/or neutral detergent soluble fibre at two protein levels: Effects on ileal apparent digestibility and caecal environment of growing rabbits. Livest. Sci. 154, 123-130.

Mateo, R.D., Wu, G., Bazer, W.B., Park, J.C., Shinzato, I., Kim, S.W., 2007. Dietary LArginine supplementation enhances the reproductive performance of gilts. J.Nutr. 137, 652-656.

Mateo, R.D., Wu, G., Moon, H.K., Carroll, J.A., Kim, W., 2008. Effects of dietary arginine supplementation during gestation and lactation on the performance of lactating primiparous sows and nursing piglets. J. Anim. Sci. 86, 827-835.677

McGuckin, M.A., Linden, S.K., Sutton, P., Florin, T.H., 2011. Mucin dynamics and enteric pathogens. Nat. Rev. Microbiol. 9, 265-278.

McWard, G.W., Nicholson, L.B., Poulton, B.R., 1967. Arginine requirements of the young rabbit. J. Nutr. 92, 118-120

Meijerink, J., Plastina, P., Vincken, J.P., Poland, M., Attya, M., Balvers, M., Gruppen, H., Gabriele, B., Witkamp, R.F., 2011. The ethanolamide metabolite of DHA, docosahexaenoylethanolamine, shows immunomodulating effects in mouse 
peritoneal and RAW264. 7 macrophages: evidence for a new link between fish oil and inflammation. Br. J. Nutr. 105, 1798-1807.

Méndez, J., De Blas, J.C., Fraga, M.J., 1986. The effects of diet and remating interval alter parturition on the reproductive performance of the commercial doe rabbit. J. Anim. Sci. 62, 1624-1634.

Menoyo, D., Gutiérrez, M., Ghanavi, H.R., García, J., Carabaño, R., 2010. Immune response to epizootic rabbit enteropathy. In: 4th Congreso de Cunicultura de las Américas. Córdoba, Argentina.

Merry, R.J., McAllan, A.B., 1983. A comparison of the chemical composition of mixed bacteria harvest from liquid and solid fractions of rumen digesta. Br. J. Nutr. 50, 701-709.

Mertens, D.R., Allen, M., Carmany, J., Clegg, J., Davidowicz, A., Drouches, M., Frank, K., Gambin, D., Garkie, M., Gildemeister, B., Jeffress, D., Jeon, C.S., Jones, D., Kaplan, D., Kim, G.N., Kobata, S., Main, D., Moua, X., Paul, B., Robertson, J., Taysom, D., Thiex, N., Williams, J., Wolf, M., 2002. Gravimetric determination of amylase-treated neutral detergent fiber in feeds with refluxing in beakers or crucibles: Collaborative study. J. AOAC Int. 85, 1217-1240.

Michelland, R.J., Dejean, S., Combes, S., Fortun-Lamothe, L., Cauquil, L., 2009. StatFigerprints: a friendly graphical interface program for processing and analysis of microbial fingerprint profiles. Mol Ecol. Res. 9, 1359-1363.

Moncada, S., Higgs, E., 1995. Molecular mechanisms and therapeutic strategies related to nitric oxide. The FASEB J. 9, 1319-1330.

Moncomble, A.S., Quennedey, B., Coureaud, G., Langlois, D., Perrier, G., Schaal, B., 2004. Newborn rabbit attraction toward maternal faecal pellets. In: Int. Soc. Develop. Psychobiol. 37th Annu. Meeting, Aix-en-Provence, France. p. 277.

Montagne, L., Piel, C., Lallès, J.P., 2004. Effect of diet on mucin kinetics and composition: nutrition and health implications. Nutr. Rev. 62, 105-114.

Monteils, V., Cauquil, L., Combes, S., Godon, J.J., Gidenne, T., 2008. Potential corespecies and satellite-species in the bacterial community within the rabbit caecum. FEMS Microb. Ecol. 66, 620-629.

Montufar-Solis, D., Klein, J.R., 2006. An improved method for isolating intraepithelial lymphocytes (IELs) from the murine small intestine with consistently high purity. J. Immunol. Methods. 308, 251-254. 
Mordenti, A.I., Sardi, L., Bonaldo, A., Pizzamiglio, V., Brogna, N., Cipollini, I., Tassinari, M., G. Zaghini., 2010. Influence of marine algae (Schizochytrium spp.) dietary supplementation on doe performance and progeny meat quality. Livest. Sci. 128, 179-184.

Morel, F.B., Oozeer, R., Piloquet, H., Moyon, T., Pagniez, A., Knol, J., Darmaun, D., Michel, C., 2015. Pre-weaning modulation of intestinal microbiota by oligosaccharides or amoxicillin can contribute to programming of adult microbiota in rats. Nutr. 31, 515-522.

Motta-Ferreira, W., Fraga, M.J., Carabaño, R., 1996. Inclusion of grape pomace, in substitution for alfalfa hay, in diets for growing rabbits. Anim. Sci. 63, 167-174.

Mowat, A.M., 2003. Anatomical basis of tolerance and immunity to intestinal antigens. Nat. Rev. Immunol. 3, 331-341.

Naomoto, Y., Yamatsuji, T., Shigemitsu, K., Ban, H., Nakajo, T., Shirakawa, Y., Motok, T., Kobayasi, M., Gunduz, M., Tanaka, N., 2005. Rational role of amino acids in intestinal epithelial cells. Int. J. Mol. Med. 16, 201-204.

Naylor, N.J., Leibel, T., Middleton, D.M., 1987. Effect of glutamine or glycine containing oral electrolyte solutions on mucosal morphology, clinical and biochemical findings, in calves with viral induced diarrhea. Can. J. Vet. Res. 61, 43-48.

Newsholme, E.A., Calder, P.C., 1997. The proposed role of glutamine in some cells of the immune system and speculative consequences for the whole animal. Nutr. 13, 728-730.

Newsholme, P., Curi, R., Pithon Curi, T., Murphy, C., Garcia, C., Pires de Melo, M., 1999. Glutamine metabolism by lymphocytes, macrophages, and neutrophils: its importance in health and disease. J. Nutr. Biochem. 10, 316-324.

Newsholme, P., 2001. Why is L-glutamine metabolism important to cells of the immune system in health, postinjury, surgery or infection?. J. Nutr. 131, 2515-2522.

Nicodemus, N., Carabaño, R., García, J., Méndez, J., De Blas, C., 1999. Performance response of lactating and growing rabbits to dietary lignin content. Anim. Feed Sci. Technol. 80, 43-54.

Nicodemus, N., García, J., Carabaño, R., De Blas, J.C., 2006. Effect of a reduction of dietary particle size by substituting a mixture of fibrous by-products for lucerne hay on performance and digestion of growing rabbits and lactating does. Livest. Sci. 100, 242-250. 
Nicodemus, N., Pereda, N., Romero, C., Rebollar, P.G., 2009. Évaluatuion de la technique d'impédance bioélectrique (IBE) puor estimer la composition corporelle de lapines reproductrices. In: 13émes Jornées de la Recherche Cunicole. LeMans, France. p. 109-112.

Nicodemus, N., Abad-Guamán, R., Delgado, R., Ocasio-Vega, C., Guenaoui, M., Menoyo, D., Carabaño, R., García, J., 2015. Evolución de la presencia de heces en el nidal durante la lactación en conejas multíparas. In: XL Symposium de cunicultura de ASESCU, Santiago de Compostela, Spain. p. 97-99.

NRC, 2012. Nutrient requirements of swine, 11th edition. National Academy Press, Washington, DC.

Okuyama, H., Urao, M., Lee, D., Drongowski, R.A., Coran, A.G., 1998. The effect of epidermal growth factor on bacterial translocation in newborn rabbits. J. Pediatr. Surg. 33, 225-228.

Otto, S.J., van Houwelingen, A.C., Badart-Smook, A., Hornstra, G., 2001. Comparison of the peripartum and postpartum phospholipid polyunsaturated fatty acid profiles of lactating and nonlactating women. Am. J. Clin. Nutr. 73, 1074-1079.

Pachikian, B.D., Neyrinck, A.M., Portois, L., De Backer, F.C., Sohet, F.M., Hacquebard, M., Carpentier, Y.A., Cani, P.D., Delzenne, N.M., 2011. Involvement of gut microbial fermentation in the metabolic alterations ocurring in $n-3$ polyunsaturated fatty acids-depleted mice. Nutr. Metab. 8, 44.

Padilha, M.T.S., Licois, D., Gidenne, T., Carré, B., Fonty, G., 1995. Relationship between microflora and caecal fermentation in rabbits before and after weaning. Reprod. Nutr. Dev. 35, 375-386.

Panigrahi, P., Gewwolb, I.H., Pamford, P., Horvath, K., 1997. Role of glutamine in bacterial transcytosis and epithelial cell injury. J. Parenter. Enteral. Nutr. 21, 7580.

Papadomichelakis, G., Zoidis, E., Fegeros, K., 2012. Dietaryly induced changes in liver composition and weight of fattening rabbits. Livest. Sci. 144, 190-196.

Parigi-Bini, R., Xiccato, G., 1998. Energy metabolism and requirements. In: De Blas, J.C., Wiseman, J, (Eds), The nutrition of the rabbit. CABI Publishing CAB International, Wallingford, UK. pp. 103-131. 
Partridge, G.G., Garthwaite, P.H., Findlay, M., 1989. Protein and energy retention by growing rabbits offered diets with increasing proportions of fibre. J. Agric. Sci. $112,171-178$.

Pascual, J., Tolosa, C., Cervera, C., Blas, E., Fernández-Carmona, J., 1999. Effect of diets with different digestible energy content on the performance of rabbit does. Anim. Feed Sci. Technol. 81, 105-117.

Pascual, J.J., Savietto, D., Cervera, C., Baselga, M., 2013. Resources allocation in reproductive rabbit does: a review of feeding and genetic strategies for suitable performance. World Rabbit Sci. 21, 123-144.

Pascual, M., Soler, M.D., Cervera, C., Pla, M., Pascual, J.J., Blas, E., 2014. Feeding programmes based on highly-digestible fibre weaning diets: Effects on health, growth performance and carcass and meat quality in rabbits. Livest. Sci. 169, 88-95.

Peeters J.E., 1988. Recent advances in intestinal pathology of rabbits and further perspectives. In: 4th World Rabbit Congress. Budapest, Hungary. 3, 293-315.

Peeters J.E., Licois, D., Su, M., Badiola, I., Rossel, JM., 2000. in: Rosell, J.M. (Ed), Enfermedades del conejo. Tomo II. Mundiprensa. pp. 163-213.

Pereda, N., 2010. Evaluación de la técnica del Análisis de Impedancia Bioeléctrica (BIA) para predecir la composición corporal: aplicación en conejas sometidas a diferentes sistemas de alimentación durante la recría, Ph D Thesis, UPM, Madrid, Spain.

Perey, D.Y.E., Good, R.A., 1968. Experimental arrest and induction of lymphoid development in intestinal lymphoepithelial tissues of rabbits. Lab. Invest.18, 15-25.

Pérez de Rozas, A.M., Carabaño, R., García, J., Rosell, J., Díaz, J.V., Barbé, J., Pascual, J.J., Badiola, I., 2005. Etiopatogenia de la enteropatía epizoótica del conejo. In: XXX Symposium de Cunicultura. Valladolid, Spain. pp. 167-174.

Petters, R.M., Johnson, B.H., Reed, M.L., Archibong, A.E., 1990. Glucose, glutamine and inorganic phosphate in early development of the pig embryo in vitro. J. Reprod. Fert. 89, 269-275.

Piattoni, F., Maertens, L., Mazzoni, D., 1999. Effect of weaning age and solid feed distribution before weaning on performances and caecal traits of young rabbits. Cahiers Options Méditérranéennes, 41, 85-91. 
Pié, S., Lalles, J.P., Blazy, F., Laffitte, J., Seve, B., Oswald, P., 2004. Weaning is associated with an upregulation of expression of cytokines in the intestine of piglets. J. Nutr. 134, 641-647.

Piel, C., Montagne, L., Seve, B., Lalles, J. P., 2005. Increasing digesta viscosity using carboxymethylcellulose in weaned piglets stimulates goblet cell numbers and maturation. J. Nutr. 13, 86-91.

Pirman, T., Ribeyreb, M.C., Mosoni, L., Rémond, D., Vrecl, M., Salobir, J., Mirand, P. P., 2007. Dietary pectin stimulates protein metabolism in the digestive tract. Nutr. $23,69-75$.

Piva, A., Prandini, A., Fiorentini, L., Morlacchin, L., Galvano, F., Luchansky, J.B., 2002. Tributyrin and lactitol synergistically enhanced the trophic status of the intestinal mucosa and reduced histamine levels in the gut of nursey pigs. J. Anim. Sci. 80, 670-680.

Pospisil, R., Mage, R.G., 1998. B-cell superantingens may play a role in B-cell development and selection in the young rabbit appendix. Cell. Immunol. 185, 93100.

Pospisil, R., Alexander, C.B., Obiakor, H., Sinha, R.K., Mage, R.G., 2006. CD5+ B cells are preferentially expanded in rabbit appendix: the role of CD5 in B cell development and selection. Dev. Comp. Immunol. 30, 711-722.

Prud'hon, M., Bel, L., 1968. Le sevrage précoce des lapereaux et la reproduction des lapines. Ann. Zootech. 17, 23-30.

Quevedo, F., Pascual, J.J., Blas, E., Cervera, C., 2003. Influencia de la madre sobre el crecimiento y la mortalidad de los gazapos en cebo. In: XXVIII Symposium de Cunicultura. Alcañiz, Spain. pp. 115-122.

Quintela, L.A., Peña, A.I., Vega, M.D., Gullón, J., Prieto, M.C., Barrio, M., Becerra, J.J., Maseda, F., Herradón, P.G., 2004. Ovulationinduction in rabbit does submitted to artificial insemination by adding buserelin to the seminal dose. Reprod. Nutr. Develop. 44, 79-88.

Ramaekers, P., Kemp, B., van der Lende, T., 2006. Progenos in sows increases number of piglets born. J. Anim. Sci. 84, 394.

Ramette, A., 2007. Multivariate analyses in microbial ecology. FEMS Microbiol. Ecol. $62,142-160$. 
Rebollar, P.G., Milanés, A., Pereda, N., Millán, P., Cano, P., Esquifino, A.I., Villarroel, M., Silván, G., Lorenzo, P.L., 2006. Oestrus synchronisation of rabbit does at early post-partum by doe-litter separation or ECG injection: Reproductive parameters and endocrine profiles. Anim. Reprod. Sci. 93, 218-230.

Rebollar, P., Pérez-Cabal, M., Pereda, N., Lorenzo, P., Arias-Álvarez, M., GarcíaRebollar, P., 2009. Effects of parity order and reproductive management on the efficiency of rabbit productive systems. Livest. Sci. 121, 227-233.

Rebollar, P.G., García-García, R.M., Arias-Alvarez, M., Millán, P., Rey, A.I., Rodríguez, M., Formoso-Rafferty, N., de la Riva, S., Masdeu, M., Lorenzo, P.L., GarcíaRebollar, P., 2014. Reproductive long-term effects, endocrine response and fatty acid profile of rabbit does fed diets supplemented with n-3 fatty acids. Anim. Reprod. Sci. 146, 202-209.

Reeds, P.J., Fjeld, C.R., Jahoor, F., 1994. Do the differences between amino acids compositions of acute-phase and muscle proteins have bearing on nitrogen loss in traumatic states?. J. Nutr. 124, 906-910.

Reynolds, L.P., Redmer, D.A., 2001. Angiogenesis in the placenta. Biol. Reprod. 64, 1033-1040.

Rezaei, R., Wang, W., Wu, Z., Dai, Z., Wang, J., Wu, G., 2013. Biochemical and physiological bases for utilization of dietary amino acids by young pigs. J. Anim. Sci. Biotechnol. 4, 7.

Rhee, K.J., Sethupathi, P., Driks, A., Lanning, D.K., Knight, K., 2004. Role of commensal bacteria in development of gut-associated lymphoid tissues and preimmune antibody repertoire. J. Immunol. 172, 1118-1124.

Rhoads, J.M., Argenzio, R.A., Chen, W.N., Rippe, R.A., Westwick, J.K., Cox, A.D., Berschneider, H.M., Brenner, D.A., 1997. L-glutamine stimulates intestinal cell proliferation and activates mitogen-activated protein kinases. Am. J. Physol. Gastrointest. Liver Physiol. 272, 943-953.

Rhoads, J. M., Niu, X., Odle, J., Graves, L.M., 2006. Role of mTOR signaling in intestinal cell migration. Am. J. Physiol. Gastrointest. Liver Physiol. 291, 510-517.

Ricote, M., Glass, C.K., 2007. PPARs and molecular mechanisms of transrepression. Biochim. Biophys. Acta Mol. Cell. Biol. Lipids. 1771, 926-935.

Robinson, J.G., Stone, N.J., 2006. Antiatherosclerotic and antithrombotic effects of omega-3 fatty acids.Am. J. Cardiol. 98, 39-49. 
Romero, C., Nicodemus, N., García-Rebollar, P., García-Ruiz, A.I., Ibáñez, M.A., De Blas, J.C., 2009. Dietary level of fibre and age at weaning affect the proliferation of Clostridium perfringens in the caecum, the incidence of Epizootic Rabbit Enteropathy and the performance of fattening rabbits. Anim. Feed Sci. Technol. $153,131-140$.

Romero, C., Nicodemus, N., Martínez de Morentin, C., García, A., de Blas, C., 2011. Effect of grinding size of barley and dehydrated alfalfa on performance and body composition of does during their early reproductive cycles. Livest. Sci. 140, 5561.

Rosell, J.M., de la Fuente, L.F., 2009. Culling and mortality in breeding rabbits. Prev. Vet. Med.. 88, 120-127.

Rotenberg, S., Eggum B.O., Hegedüs, M., Jacobsen, I., 1982. The effect of pectin and microbial activity in the digestive tract of faecal excretion of amino acids, fatty acids, thiamin, riboflavin, and niacin in young rats. Acta Agric. Scan. 32, 309319.

Russo, G.L., 2009. Dietary $n-6$ and $n-3$ polyunsaturated fatty acids: from biochemistry to clinical implications in cardiovascular prevention. Biochem. Pharmacol. 77, 937-946.

Ruth, M.R., Field, C.J., 2013. The immune modifying effects of amino acids on gutassociated lymphoid tissue. J. Anim. Sci. Biotechnol. 4, 27.

Saiz, A., García-Ruiz, A.I., Martin, E., Fernández, A., Nicodemus, N. 2013a. Aplicación de la técnica de Impedancia Bioeléctrica al estudio de la composición química de la canal de conejos de 35 a 63 días de edad. In: XXXVIII Symposium de Cunicultura de ASESCU. Zamora, Spain. p. 162-165.

Saiz, A., García-Ruiz, A.I., Martin, E., Fernández, A., Nicodemus, N. 2013b. Evaluación de la técnica de Impedancia Bioeléctrica (BIA) para estimar la composición química de la canal de conejos de 35 a 63 días de edad. In: XXXVIII Symposium de Cunicultura de ASESCU. Zamora, Spain. p. 166-169.

Saiz, A., García-Ruiz, A.I., Fuentes-Pila, J., Nicodemus, N. 2017. Applicaton of bioelectrical impedance analysis to asses rabbit's body composition from 25 to 77 days of age. J. Anim. Sci. 95, 2782-2793. 
Santomá, G., de Blas, J.C., Carabaño R.M., Fraga, M.J., 1987. The effects of different fats and their inclusion level in diets for growing rabbits. Anim. Prod. 45, 291300.

SAS, Statistical Analysis System Institute Inc., 1991. User's Guide, Statistics, Version 6.03. Edition SAS Institute Inc., Cary, NC, USA.

Satchithanandam, S., Vargofcak-Apker, M., Calvert. R.J., Leeds, A.R., Cassidy, M.M., 1990. Alteration of gastrointestinal mucin by fiber feeding in rats. J. Nutr. 120, 1179-1184.

Savietto, D., Marono, S., Martínez, I., Martínez-Paredes, E., Ródenas, L., Cervera, C., Pascual, J.J., 2016. Patterns of body condition use and its impact on fertility. World Rabbit Sci. 24, 39-45.

Scapinello, C., Gidenne, T., Fortune-Lamothe, L., 1999. Digestive capacity of the rabbit during the post-weaning period, according to the milk/solid feed intake pattern before weaning. Reprod. Nutr. Dev. 39, 423-432.

Schmitz, G., Ecker, J., 2008. The opposing effects of n-3 and n-6 fatty acids. Prog. Lipid Res. 47, 147-155.

Self, J.T., Spencer, T.E., Johnson, G.A., Hu, J.B., Bazer, F.W., Wu, G.Y., 2004. Glutamine synthesis in the developing porcine placental. Biol. Reprod. 70, 14441451.

Sheng, Y. H., Triyana, S., Wang, R., Das, I., Gerloff, K., Florin, T. H., Sutton, P., McGuckin, M. A., 2013. MUC1 and MUC13 differentially regulate epithelial inflammation in response to inflammatory and infectious stimuli. Mucosal immunol. 6, 557-568.

Sirotek, K., Santos, E., Benda, V., Marounek, M., 2003. Isolation, identification and characterization of rabbit mucinolytic bacteria. Acta Vet. Brno. 72, 365-370.

Skřivanová, E., Marounek, M., Dlouha, G., Kaňka, J., 2005. Susceptibility of Clostridium perfringens to C2-C18 fatty acids. Lett. Appl. Microbiol. 41, 77-81.

Skřivanová, V., Marounek, M., 2006. A note on the effect of triacylglycerols of caprylic and capric acid fatty acid on performance, mortality, and digestibility of nutrients in young rabbits. Anim. Feed Sci. Technol. 127, 161-168.

Sladek, S. M., Magness, R. R., Conrad, K. P., 1997. Nitric oxide and pregnancy. Am. J. Physiol. Regul. Integr. Comp. Physiol. 272, 441-463. 
Smith, H.W., 1965. The development of the flora of the alimentary tract in young animals. J. Pathol. Bacteriol. 90, 495-513.

Sprecher, H., 2000. Metabolism of highly unsaturated n-3 and n-6 fatty acids. Biochim. Biophys. Acta, Mol. Cell. Biol. Lipids. 1486, 219-231.

Steibel, J.P., Poletto, R., Coussens, P.M., Rosa, G.J., 2009. A powerfull and flexible linear mixed model framework for the analysis of relative quantification RT-PCR data. Genomics. 94, 146-152.

Stepanková, R., Kovaru, F., Kruml, J., 1980. Lymphatic tissue of the intestinal tract of germfree and conventional rabbits. Folia Microbiol. 25, 491-495.

Stow, J.L., Low, P., Offenhaüser, C., Sangermani, D., 2009. Cytokine secretion in macrophages and other cells: Pathways and mediators. Immunobiol. 214, 601612.

Suchner, U., Heyland, D.K., Peter, K., 2002. Immune-modulatory actions of arginine in the critical ill. Br. J. Nutr. 87, 121-132.

Suenaga, R., Tomonaga, S., Yamane, H., Kurauchi, I., Tsuneyoshi, Y., Sato, H., Denbow, D.M., Furuse, M., 2008. Intracerebroventricular injection of 1-arginine induces sedative and hypnotic effects under an acute stress in neonatal chicks. Amino Acids. 35, 139-146.

Sukhija, P.S., Palmquist, D.L., 1988. Rapid method for determination of total fatty acid content and composition of feedstuffs and feces. J. Agric. Food Chem. 36, 12021206.

Sumida, C., Graber, R., Nunez, E., 1993. Role of fatty acids in signal transduction: modulators and messengers. Prostaglandins Leukot. Essent. Fatty Acids.48, 117122.

Szalo, I.M., Lassence, C., Licois, D., Coudert, P., Poulipoullis, A., Vindevogel, H., Marlier, D., 2007. Fractionation of the reference inoculum of epizootic rabbit enteropathy in discontinuous sucrose gradient identifies aetiological agents in high density fractions. Vet. J. 173, 652-657.

Taghouti, M., Macchiavelli, R., García, J., Demey, J., Nicodemus, N., 2011. Relación entre la composición química corporal. la fertilidad y la prolificidad en conejas primíparas. In: XXXVI Symposium de Cunicultura. Peñíscola, Spain. pp. 85-88. 
Tan, B.E., Yin, Y.L., Kong, K.F., Li, T.J., Huang, R.L., Zhang, P., Yin, F.G., Shinzato, I., Kim, S.W., Wu, G.Y., 2007. Dietary arginine supplementation enhances the immune status of piglets. J. Anim. Sci. 85.

Tan, B., Li, X.G., Kong, X., Huang, R., Ruan, Z., Yao, K., Deng, Z., Xie, M., Shinzato, I., Yin, Y., Wu, G., 2009. Dietary L-arginine supplementation enhances the immune status in early-weaned piglets. Amino acids. 37, 323-331.

Tanghe, S., De Smet, S., 2013. Does sow reproduction and piglet performance benefit from the addition of n-3 polyunsaturated fatty acids to the maternal diet? Vet. J. 197, 560-569.

Tanghe, S., Missotten, J., Raes, K., Vangeyte, J., De Smet, S., 2014. Diverse effects of linseed oil and fish oil in diets for sows on reproductive performance and preweaning growth of piglets. Livest. Sci. 164, 109-118.

Tapiero, H., Mantle, G., Couvreur, P., Tew, K.D., 2002. Dossier: Free amino acids in human health and pathologies- I. Arginine. Biomed. Pharmacother. 56, 439-445.

Tazzoli, M., Trocino, A., Birolo, M., Radaelli, G., Xiccato, G., 2015 Optimizing feed efficiency and nitrogen excretion in growing rabbits by increasing dietary energy with high-starch, high-soluble fibre, low insoluble fibre supply at low protein levels Livest. Sci. 172, 59-68.

Theilgaard, P., Sánchez, J.P., Pascual, J.J., Friggens, N.C., Baselga, M., 2006. Effect of body fatness and selection for prolificacy on survival rabbit does assessed using a cryopreserved control population. Livest. Sci. 103, 65-73.

Theilgaard, P., Baselga, M., Blas, E., Friggens, N.C., Cervera, C., Pascual, J.J., 2009. Differences in productive robustness in rabbits selected for reproductive longevity or litter size. Anim. 3, 637-646.

Trocino, A., Fragkiadakis, M., Radaelli, G., Xiccato, G., 2010. Effect of dietary soluble fibre level and protein source on growth, digestion, caecal activity and health of fattening rabbits. World Rabbit Sci. 18, 199-210.

Trocino, A., Fragkiadakis, M., Majolini, D., Carabaño, R., Xiccato, G. 2011., Effect of the increase of dietary starch and soluble fibre on digestive efficiency and growth performance of meat rabbits. Anim. Feed Sci. Technol. 165, 265-277.

Trocino A., García, J., Carabaño, R, Xiccato, G., 2013a. A meta-analysis on the role of soluble fibre in diets for growing rabbits. World Rabbit Sci. 21, 1-15. 
Trocino, A., Fragkiadakis, M., Majolini, D., Tazzoli, M., Radaelli, G., Xiccato, G., 2013 b. Soluble fibre, starch and protein level in diets for growing rabbits: Effects on digestive efficiency and productive traits. Anim. Feed Sci. Technol. 180, 73-82.

Urao, M., Moy, J., Van Camp, J., Drongowski, R., Altabba, M., Coran, A.G., 1995. Determinant of bacterial translocation in the newborn: small bowel versus large bowel colonization. J. Pediatr. Surg. 30, 831-836.

Urao, M., Teitelbaurn, D.H., Drongowski, R.A., Coran, A.G., 1996. The association of gut-associated lymphoid tissue and bacterial translocation in the newborn rabbit. J. Ped. Surg. 31, 1482-1487.

Van der Hulst, R.R., Meyenfeldt, M.F., Tiebosch, A., Buurman, W.A., Soeters, P.B., 1997.Glutamine and intestinal immune cells in humans. J. Parenter. Enteral Nutr. 21, 310-315.

Vázquez, E., Gil, A., García-Olivares, E., Rueda, R., 2000. Weaning induces an increase in the number of specific cytokine-secreting intestinal lymphocytes in mice. Cytokine. 12, 1267-1270.

Vlaeminck, B., Fievez, V., Cabrita, A.R.J., Fonseca, A.J.M., Dewhust. R.J., 2006. Bioactive components of milk. Anim. Feed Sci. Technol. 131, 389-417.

Volek, Z., Marounek, M., Skrivanova, V., 2007. Effect of a starter diet supplementation with mannan-oligosaccharide or inulin on health status, caecal metabolism, digestibility of nutrients and growth of early-weaned rabbits. Anim. Feed. Sci. Technol. 150, 283-294.

Volek, Z., Marounek, M., Volková, L., Kudrnová. E., 2014. Effect of diets containing whole white lupin seeds on rabbit doe milk yield and milk fatty acid composition as well as the growth and health of their litters. J. Anim. Sci. 92, 2041-2049.

Wallace, F.M., Mach, A.S., Keller, A.M., Lindsay, J.A., 1999. Evidene for Clostridium perfringens enterotoxin (CPE) inducing a mitogenic and cytokine response in vitro and a cytokine response in vivo. Curr. Microbiol. 38, 96-100.

Wang, J.J., Li, D.F., Dangott, L.J., Wu, G.Y., 2006. Proteomics and its role in nutrition research . J Nutr. 136, 1759-1762.

Wang, J., Chen, L., Li, P., Li, X., Zhou, H., Wang, F., Li, D., Yin, Y., Wu, G., 2008 a. Gene expression is altered in piglet small intestine by weaning and dietary glutamine supplementation. J Nutr. 138, 1025-1032. 
Wang, X., Li, W., Li, N., Li, J., 2008b. $\omega$-3 fatty acids-supplemented parenteral nutrition decreases hyperinflammatory response and attenuates systemic disease sequelae in severe acute pancreatitis: a randomized and controlled study. J. Parenter. Enteral Nutr. 32, 236-241.

Welsh, J.K., May, J.T., 1979. Anti-infective properties of breast milk. J. Pediatr. 94, 1-9.

White, J.J., Hoper, M., Parks, R.W., Clements, W.D., Diamont, T., 2005. Glutamine improves intestinal barrier function in experimental biliary obstruction. Eur. Surg. Res. 37, 342-347.

Whiting, C.V., Bland, P.W., Tarlton, J.F., 2005. Dietary n-3 polyunsaturated fatty acids reduce disease and colonic proinflammatory cytokines in a mouse model of colitis. Inflamm. Bowel dis. 11, 340-349.

Williams, A.E., 2012. Immunology. Mucosal and body surface defenses. WileyBlackwell, Oxford, UK.

Wu, G., Borbolla, A.G., Knabe, D.A., 1994. The uptake of glutamine and release of arginine, citrulline and proline by the small intestine of developing pigs. J. Nutr. $124,2347-2444$.

Wu, G., Knabe, D.A., 1994. Free and protein-bound amino acids in sow's colostrum and milk. J. Nutr. 124, 415.

Wu, G., 1996. Effects of concanavalin A and phorbol myristate acetate on glutamine metabolism and proliferation of porcine intestinal intraepithelial lymphocytes. Comparative Biochemistry and Physiology Part A: Physiology 114, 363-368.

Wu, G., Meier, S.A., Knabe, D.A., 1996. Dietary glutamine supplementation prevents jejunal atrophy in weaned pigs. J. Nutr. 126, 2578.

Wu GY., 1998. Intestinal mucosal amino acid catabolism. J Nutr.128, 1249-1252.

Wu, G.Y., Morris, S.M., 1998. Arginine metabolism: nitric oxide and beyond. Biochem. J. 336, 1-17.

Wu, G., Pond, W.G., Ott, T., Bazer, F.W., 1998. Maternal dietary protein deficiency decreases amino acid concentrations in fetal plasma and allantoic fluid of pigs. J. Nutr. 128, 894-902.

Wu, G., Ott, T.L., Knabe, D.A., Bazer, F.W., 1999. Amino acid composition of the fetal pig. J. Nutr. 129, 1031-1038. 
Wu, G.Y., Haynes, T.E., Li, H., Yan, W., Meininger, C.J., 2001. Glutamine metabolism to glucosamine is necessary for glutamine inhibition of endothelial nitric oxide synthesis. Biochem J. 353, 245-252.

Wu, G., Meininger, C.J., 2002. Regulation of nitric oxide synthesis by dietary factors. Ann. Rev. Nutr. 22, 61-86.

Wu, G., Bazer, F.W., Cudd, T.A., Meininger, C.J., Spencer, T.E., 2004a. Maternal nutrition and fetal development. J. Nutr. 134, 2169-2172.

Wu, G.Y., Fang, Y.Z., Yang, S., Lupton, J.R., Turner, N.D., 2004b. Glutathione metabolism and its implications for health. J. Nutr.134, 489-492.

Wu, G., Bazer, F.W., Hu, J., Johnson, G.A., Spencer, T.E., 2005. Polyamine synthesis from proline in the developing porcine placenta. Biol. Reprod. 72, 842-850.

Wu, G., Bazer, F.W., Davis, T.A., Jaeger, L.A., Johnson, G.A., Kim, S.W., Knabe, D.A., Meininger, C.J., Spencer, T.E., Yin, Y., 2007. Important roles for the arginine family amino acids in swine nutrition and production. Livest. Sci. 112, 8-22.

Wu, G.Y., 2009. Amino acids: metabolism, functions, and nutrition. Amino Acids. 37, 117.

Wu, G.F., Bazer, F.W., Johnson, G.A., Knabe, D.A., Burghardt, R.C., Spencer, T.E., Li X.L., Wang, J.J., 2011. Important roles for L-glutamine in swine nutrition and production. J. Anim. Sci. 89, 2017-2030.

Wu, G., 2013. Functional amino acids in nutrition and health. Amino Acids. 45, 407-411.

Xiccato, G., Trocino, A., Sartori, A., Queaque, P.I., 2000. Early weaning of rabbits: effect of age and diet on weaning and post-weaning performance. In.: 7th World Rabbit Congress, Valencia. pp. 483-490.

Xiccato, G., Trocino, A., Sartori, A., Queaque, P.I., 2004. Effect of parity order and litter weaning age on the performance and body energy balance of rabbit does. Livest. Prod. Sci. 85, 239-251.

Xiccato, G., Trocino, A., Carraro, C., Fragkiadakis, M., Majolini, D., 2008. Digestible fibre to starch ratioand antibiotic treatment time in growing rabbits affected by epizootic rabbit enteropathy. In: 9 th World Rabbit Congress. pp 10-13.

Xiccato, G., Trocino, A., 2010. Energy and protein metabolism. in: De Blas, C., Wiseman, J. (Eds.), Nutrition of the rabbit. 2nd edition. CABI Publishing CAB International, Wallingford, UK. pp. 83-118. 
Xiccato, G., Trocino, A., Majolini, D., Fragkiadakis, M., Tazzoli, M., 2011. Effect of decreasing dietary protein level and replacing starch with soluble fibre on digestive physiology and performance of growing rabbits. Anim. 8, 1179-1187.

Yamauchi, J., Miyazaki, T., Iwasaki, S., Kishi, I., Kuroshima, M., Tei, C., Yoshimura, Y., 1997. Effects of nitric oxide on ovulation and ovarian steroidogenesis and prostaglandin production in the rabbit. Endocrinology, 138, 3630-3637.

Yang, X.F., Jiang, Z.Y., Gong, Y.L., Zheng, C.T., Hu, Y.J., Wang, L., Huang, L., Ma, X.Y., 2016. Supplementation of pre-weaning diet with L-arginine has carry-over effect to improve intestinal development in young piglets. Can. J. Anim. Sci. 96, 52-59.

Yemm, E.W., Willis, A.J., 1954. The estimation of carbohydrates in plant extracts by anthrone. Biochem. J. 57, 508-514.

Yi, G.F., Allee, G.L., Knight, C.D., Dibnert, J.J., 2005. Impact of glutamine and oasis hatchling supplement on growth performance, small intestine morphology and immune response of broilers vaccinated and challenged with Eimeria maxima. Poult. Sci. 84, 283-293.

Yoo, S.S., Field, C.J., McBurney, M.I., 1997. Glutamine supplementation maintaits intramuscular glutamine concentrations and normalizes lymphocyte function in infected early weaned pigs. J. Nutr. 127, 2253-2259.

Yu, B., Chiou, P.W., 1997. The morphological changes of intestinal mucosa in growing rabbits. Lab. Anim. 31, 254-263.

Zarrow, M., Denenberg, V., Anderson, C., 1965. Rabbit: frequency of suckling in the pup. Sci. 150, 1835-1836.

Zeng, X., Wang, F., Fan, X., Yang, W., Zhou, B., Li, P., Yin, Y., Wu, G., Wang, J., 2008. Dietary arginine supplementation during early pregnancy enhances embryonic survival in rats. J. Nutr. 138, 1421-1425.

Zhou, X., Wu, X., Yin, Y., Zhang, C., He, L., 2012. Preventive oral supplementation with glutamine and arginine has beneficial effects on the intestinal mucosa and inflammatory cytokines in endotoxemic rats. Amino acids. 43, 813-821.

Zhu, J., Paul, W.E., 2009. CD4+ T cells: fates, functions and faults. Blood. 112, 5.

Ziegler, T.R., Evans, M., Estavirez, C., Jones, D.P., 2003. Tropic and cytoprotective nutrition for intestinal adaptation, mucosal repair and barrier function. Annu. Rev. Nutr. 23, 229-261. 
Zier-Rush, C.E., Kuntzman, A., Schmidt, T., et al., 2012. Arginine supplement in early and late pregnant sows did not improve litter size or birth weight. J Anim Sci 90, 34. 